\title{
Paisagens Frágeis
}




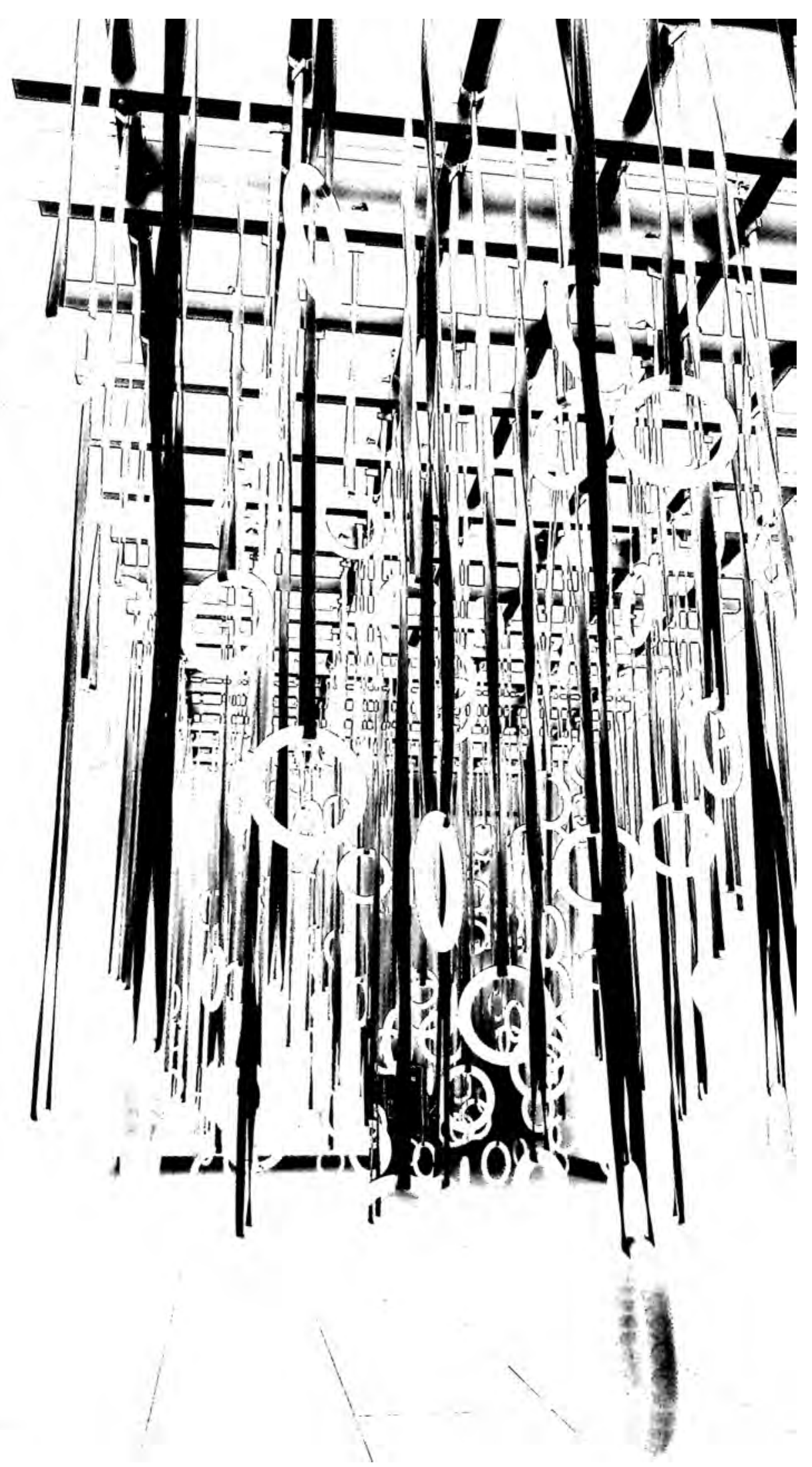


Programa de Pós-Graduação em Artes Cênicas

Escola de Comunicações e Artes - ECA

Universidade de São Paulo - USP

Giselly Brasil

Paisagens Frágeis,

um estudo sobre condições espaciais e instalativas em procedimentos do coreógrafo William Forsythe

São Paulo - SP

2016 
Giselly Brasil

\section{Paisagens Frágeis,}

um estudo sobre condições espaciais e instalativas em procedimentos do coreógrafo William Forsythe

Tese apresentada como requisito parcial à obtenção do grau de Doutora em Artes. Programa de Pós-Graduação em Artes Cênicas. Área de Concentração: Pedagogia do Teatro. Linha de Pesquisa: Formação do artista cênico.

Orientadora: Profa.Dra. Elisabeth Silva Lopes Co-orientador: Prof. Dr. Gerald Siegmund (Universidade de Giessen)

São Paulo - SP

2016 
Catalogação na Publicação

Serviço de Biblioteca e Documentação

Escola de Comunicações e Artes da Universidade de São Paulo Dados fornecidos pelo(a) autor(a)

Brasil, Giselly

Paisagens Frágeis: um estudo sobre condições espaciais e instalativas em procedimentos do coreógrafo William Forsythe / Giselly Brasil. -- São Paulo: G. Brasil, 2016. 279 p.: il.

Tese (Doutorado) - Programa de Pós-Graduação em Artes Cênicas - Escola de Comunicações e Artes / Universidade de São Paulo.

Orientadora: Profa. Dra. Elisabeth Silva Lopes

Coorientador: Prof. Dr. Gerald Siegmund

Bibliografia

1. Artes Cênicas I. Silva Lopes, Profa. Dra. Elisabeth II. Titulo.

CDD 21.ed. - 700 


\author{
Giselly Brasil
}

\begin{abstract}
Paisagens Frágeis,
um estudo sobre condições espaciais e instalativas em procedimentos do coreógrafo William Forsythe
\end{abstract}

Tese apresentada para a obtenção do título de Doutora, na linha de pesquisa: Formação do artista cênico, em sua forma final pelo Programa de Pós-Graduação em Artes Cênicas da Universidade do Estado de São Paulo, em de

\title{
Profa.Dra. Elisabeth Silva Lopes
}

Coordenadora do PPGAC

Apresentada à Comissão Examinadora, integrada pelos professores:

Orientador:

Profa.Dra. Elisabeth Silva Lopes

Universidade do Estado de São Paulo 
Membro:

Membro:

Membro:

Membro:

São Paulo - SP

2016 


\section{Agradecimentos:}

Primeiramente, gostaria de agradecer à professora Elisabeth Silva Lopes, orientadora deste trabalho, por toda a confiança e por todos os laços de afeto nesses anos de pesquisa. Foi a Beth quem me perguntou pela primeira vez, enquanto bebíamos um café em Barcelona, por qual caminho profissional eu optaria, se prático ou teórico. E desde lá que a indeterminação tornou-se o meu tema. Os giros e os abalos que me confrontam com o indefinido passaram a ser uma constante. Desde então que minhas escritas experimentam as mais variadas direções e que meu corpo, depois de tanto ler, se entrega ao chão, ao lugar das coisas físicas, da matéria sobre a qual desenho minhas abstrações.

Agradeço ao professor Gerald Sigmund, meu co-orientador na Universidade de Giessen, na Alemanha, por toda a gentileza, por todas as conversas, por toda a informalidade que me deixou sempre tão a vontade para me arriscar a pensar em alemão e por todo o apoio desde o nosso primeiro contato, em maio de 2013. Obrigada ainda à professora Bojana Kunst pela a multiplicidade de referenciais e pela simplicidade em conduzir diálogos intensos e complexos.

Obrigada ao William Forsythe pela conversa generosa e pelos dias em que pude acompanhar a remontagem do último trabalho da The Forsythe Company, em Frankfurt. Agradeço a toda a equipe e principalmente ao Thierry Guiderdone e ao Julian Gabriel Richter pelas conversas e pelas importantes fontes de pesquisa.

Agradeço ainda ao professor Luiz Fernando Ramos, pelo olhar preciso e pelas considerações pontuais, em meu exame de qualificação, que foram fundamentais para o processo de estruturação desta pesquisa. Obrigada à professora Sandra Meyer, que me acompanha desde a graduação, e que avalia meus textos com tanta dedicação e interesse. Obrigada ao professor Edélcio Mostaço, que mesmo distante nesse processo da tese, se fez presente em pensamentos e reflexões que voltam sempre, desde o processo do mestrado. Obrigada ao professor Carlos Fajardo pelas experiências e trocas sobre noções de instalação.

Agradeço aos meus pais, sempre e por toda a vida, por acreditarem na educação, por acreditarem, sem referenciais bibliográficos, que o conhecimento é uma porta de acesso a nós mesmos e ao mundo. Em memória, agradeço ao meu pai pelo exemplo. Hoje, quando me sento para trabalhar, é nessa força que me inspiro e é assim que ele habita os meus dias de estudo. A minha mãe, agradeço todos os dias pela sua alegria e por ser ela a minha grande mestra de uma educação sensível que me ensina a ver detalhes invisíveis, observar a variação inesperada das cores e a beleza de sol tocando pedras ancestrais.

Ao meu grande amor, companheiro, amigo, confidente e parceiro em dias de chuva, sol ou neve, o meu infinito agradecimento. Humberto Marchesi, obrigada por cruzar geografias comigo, por todas as conversas demoradas, por todos os brindes de comemorações que muitas vezes nem sabíamos quais eram, por todas as gargalhadas, por experimentarmos juntos outros idiomas, culturas e por toda luz e parceria. Obrigada por todo o afeto e por todo amor que se estende ao meu trabalho, ao meu sacro-ofício, como você mesmo diz.

Agradeço ao grupo de estudos Theater Architecture, do The International Federation for Theatre Research, e especialmente a Juliet Rufford e ao Andrew Filmer pelas conversas, encontros e trocas práticas. 
Ademais, agradeço a todos que cruzam os caminhos desta pesquisa nesses anos intensos de vida, de estudos e aprendizados. Agradeço a Bianca Sciliar por me apresentar o primeiro texto sobre as práticas do William Forsythe, a Adriana Palma pela parceria quando a tese era ainda um projeto, a Aline Langendonck pelas conversas demoradas sobre desenhos, a Lia Laranjeira pelas conversas sobre esse processo intenso e transformador que é cruzar fronteiras e pesquisar impressões que se misturam à pele, a Maria Luzinete da Silva pela ajuda nos momentos finais desta tese. Obrigada ainda aos amigos que viram família, obrigada Stefany Cunha, Vanessa Lorenz, Rosa Ribeiro e Mariana Palmeira. Obrigada aos meus irmãos Luciani e Ivi Brasil e as minhas sobrinhas Nádia e Natália Brasil pela presença em meus dias.

Agradeço imensamente ao DAAD - Deutscher Akademischer Austausch Dienst - principal apoiador desde trabalho. A bolsa de pesquisa de doutorado do DAAD foi determinante para a produção desta pesquisa. Agradeço ao governo alemão pela confiança, apoio e respeito com que fui recebida como estudante e pesquisadora. Obrigada ainda a toda equipe do DAAD que contribuiu com simplificações burocráticas que muito ajudam o pesquisador em seu processo de pesquisa e imersão. Obrigada especialmente a Maria Salgado por todo apoio e ajuda nesses anos na Alemanha.

Este estudo foi financiado ainda, nos meses iniciais, pela bolsa CAPES e no período anterior a ida para a Alemanha, pela FAPESP. O meu agradecimento a essas duas importantes agências de fomento à pesquisa no Brasil. 
À vida nova que se molda em meu corpo, aos chutes, torções e pensamentos que se revelam nos ossos, no ventre e nesse sopro de vida que é gerado longe do olhos, lá onde a terra alimenta a vida. A você, minha filha. 
Paisagens frágeis

Abertura 14

\section{Desvios 31}

A descoberta 34

O olhar ambulante 36

A escrita 37

O início 38

A tese 39

A sala de ensaio 41

Pontilhados 42

Passagens 44

Berlim, julho de 2013. 45

\section{Linhas 50}

William Forsythe 51

Volumes e vetores no palco 61

Corpo- espaço - corpo 67

O balé 68

O sistema Laban 74

Respiração 78

\section{Fstruturas Vazadas 86}

Desenhar o espaço 87

Heterotopia ou sobreposição de lugares 95

Kammer Kammer ou perambulações do olhar 102

Dia 16 de março de 2015, sol em Frankfurt 103

Endless House ou a casa em expansão 114

Mudanças de lugar 121

\section{Lugares em construção 123}

Pressão sobre as margens 126

Ocupação Bockenheimer 129

Lugares públicos 138

Sobre a instituição 145 
Subjetividades ambulantes 146

Reinventar lugares 150

Formações Temporárias 151

Advertências I 152

Transições 153

Crise da representação 154

Espaços 160

Hélio e Lygia 166

Arquitetura teatral 168

Helio Oiticica 169

Lygia Clark 173

Fragilidades 178

Advertência II 179

\section{Suspensões 182}

Duchamp 185

Objeto 187

Minimalismo 189

Materialidade, Richard Serra 191

Coreografia 193

O que são os Objetos Coreográficos? 199

Objetos oscilatórios ¿2え

Teatralidades contemporâneas 226

Os Objetos Coreográficos em experiências teatrais 230

Paragens 233

Paisagens em suspensão 234

Uma perspectiva estética 238

Noções nômades 239

O desenho 244

Educação estética 247

A prática 248

Interações e aderências 253

\section{Reticências 257}

William Forsythe em linhas aderentes 259 
Linhas finais 263

Desacelerar 264

Referências bibliográficas 268 


\section{Resumo}

O foco de interesse deste trabalho reside no mapeamento e na investigação de procedimentos presentes na produção de William Forsythe que estimulam a reflexão sobre a prática cênica e o fenômeno da arte sob uma perspectiva transitiva e espacial. Mover, alterar perspectivas e sugerir o aparecimento de novos ângulos, pesos e intensidades é interferir nas dinâmicas que geram campos instalativos e paisagens frágeis nas quais a percepção está em constante movimento. Qualidades e características presentes nos trabalhos de Forsythe, sobretudo na série Objetos Coreográficos, serão apresentadas aqui como eixos orientadores de discussões que, ao problematizarem conceitos e fundamentos sobre movimento e espaço, lançam diferentes possibilidades de observação sob o fenômeno teatral. Os Objetos Coreográficos, ponto de partida e foco deste estudo, são propostas ou mecanismos de interação entre corpo e espaço, seja o corpo do artista ou do espectador, que incentivam reflexões sobre a arte como um extenso campo de investigação e produção de conhecimento. Ao promoverem impactos físicos, incursões espaciais e desvios de referenciais da percepção, os Objetos Coreográficos tencionam limites entre as artes cênicas, as artes visuais, a arquitetura, a dança e a filosofia ao mesmo tempo em que promovem a superação de padrões e conceitos instituídos e inauguram campos de conhecimento.

Palavras-chave: William Forsythe. Objetos Coreográficos. Espaço. Instalação. Educação estética. 


\begin{abstract}
The focus of this work lies in mapping and researching the procedures in the production of William Forsythe which stimulate the reflection about the theatrical practice and the art phenomenon from a transitive and spatial perspective. Moving, changing perspectives and suggesting the emergence of new angles, weights and intensities is about interfering in the dynamics that generate "instalatives" fields, fragile landscapes in which the perception is constantly moving. Qualities and characteristics present in the works of Forsythe, especially in the Choreographic Objects series, will appear here as guiding axis of discussions, to problematize concepts and fundamentals of movement and space, throw different possibilities for observation under the theatrical phenomenon. The Choreographic Objects, starting point and focus of this study, are proposes or mechanisms of interaction between body and space, the body of the artist or the viewer, encouraging reflections on art as an extensive field of research and production of knowledge. Promoting physical impacts, spatial incursions and deviation of perception references, the Choreographic Objects discuss the boundaries between theatre, fine arts, architecture, dance and philosophy while promoting the overcoming of standards and instituted concepts and inaugurate fields of knowledge.
\end{abstract}

Keywords: William Forsythe. Choreographic Objects. Space. Installation. Aesthetic Education. 
Paisagீens frágீeis são formações temporárias, espaços que produzimos, que habitamos, que agem sobre nós, que cruzamos, são pontos que se espalham pelo corpo, ressonâncias que vibram o entorno e perturbações ambientais. Paisagens são linhas que se esboçam e se apagam, trajetos criados em movimento e pontilhados que alteram rotas previsíveis. Paisagem não se restringe àquilo que repousa sobre a tela, mas se manifesta também nos lugares que visito com meus sentidos, a desorientação do olhar, as sobras, as sombras, os respiros, os intervalos, as dinâmicas entre corpo, espaço e uma infinidade de tons, cores, alturas, intensidades, formas, pesos e massas que negociam entre si. Paisagem é aqui lugar frágil, rearticulável, o instante em que eu atravesso o quadro e viro tinta dispersa que avança e tinge arquiteturas, janelas e paredes vazias. Paisagens são lugares em movimento, névoa no início da manhã e sereno frio que cobre telhados enquanto é madrugada. Paisagens são as órbitas dos meus sentidos sempre em evolução descobrindo detalhes e possibilidades de pisar a grama, ouvir o som do mar e notas musicais inaudíveis de canções antigas. Paisagens são livros, notas, canções, poemas, peças de teatro, instantes que disparam possibilidades de experiência estética, sensorial e sensível com o mundo. Ciclo contínuo de criação e destruição de lugares. Paisagens frágeis são campos, áreas em expansão, dinâmicas ou potencialidades que acionam movimentos entre corpos, objetos, partículas, tonalidades e transformam espacialidades. Lugares que se sobrepõem, heterotopias, topias, espaços distintos entrelaçados, ambientes com dimensões que se me multiplicam, que são visíveis e invisíveis, que se revelam e se apagam. 


\section{Abertura}

Na tradição filosófica materialista inaugurada por Epicuro e Lucrécio, os átomos caem paralelos no vazio, ligeiramente em diagonal. Se um desses átomos se desvia de sua rota "provoca um encontro com o átomo vizinho e de encontro em encontro, uma série de choques e o nascimento do mundo." Assim nascem as formas, a partir do "desvio" e do encontro aleatório entre dois elementos até então paralelos. Para criar um mundo, este encontro deve ser duradouro. Encontros duradouros, linha e cores inscritas na superfície de um quadro de Delacroix, os resíduos de objetos que aparecem nos "quadros Merz" de Schwitters, as performances de Chris Burden: para além da qualidade colocada no plano ou no espaço, se revelam como duradouros uma vez que seus componentes formam um conjunto cujo sentido "persiste" no momento do nascimento, criando "possibilidades de vida" novas. (BORRIAUD, 2008:19, tradução nossa) ${ }^{1}$.

Uma pesquisa sobre o espaço requer um mapeamento de pontos trepidantes que se agem na desarticulação, na desmontagem e na reconfiguração de referenciais. É preciso olhar com acuidade as linhas frágeis que esboçam o surgimento de lugares precários, efêmeros e desorientadores de sentidos.

É na vibração e no tremor que inauguram-se espaços, que os sentidos se organizam em novos arranjos e que observamos o já conhecido sob diferentes perspectivas. Perspectiva, aliás, é aquilo que foge do fundo da tela, rodopia, percorre labirintos e aciona dinâmicas que vinculam corpo e espaço.

Os percursos, as linhas e os desenhos que surgem enquanto caminhamos pelas cidades, enquanto conhecemos paisagens ou no momento em que criamos cenas, ambientes, situações ou intervenções artísticas estão diretamente relacionados com o modo como habitamos ou ativamos interações entre materiais, memórias, objetos, traços, presenças, palavras, sons, ruídos, silêncios, ausências, intensidades e qualidades que se interpõem em nosso campo perceptivo.

E é sob esse ponto de vista que apresento aqui um estudo sobre o espaço como ambiente frágil, paisagem sensorial e dinâmica que acontece como fluxo, como cruzamento de impressões que desafiam o olhar e os sentidos.

\footnotetext{
${ }^{1}$ Texto original: "En la tradición filosófica materialista que inauguraron Epicuro y Lucrecio, los átomos caen paralelos en el vacío, ligeramente en diagonal. Si uno de esos átomos se desvía de su recorrido, "provoca un encuentro con el átomo vecino y de encuentro en encuentro, una serie de choques y el nacimiento de un mundo". Así nacen las formas, a partir del "desvío" y del encuentro aleatorio entre dos elementos hasta entonces paralelos. Para crear un mundo, este encuentro debe ser duradero: los elementos que lo constituyen deben unirse en una forma, es decir que debe haber posesión de un elemento por otro (decimos que el hielo "se solidifica"). La forma puede definirse como un encuentro duradero. Encuentros duraderos, líneas y colores inscriptos en la superficie de un cuadro de Delacroix, los objetos desechos que aparecen en los "cuadros Merz" de Schwitters, las performances de Chris Burden: más allá de la calidad de la puesta en página o de la puesta en el espacio, se revelan como duraderos a partir de que sus componentes forman un conjunto cuyo sentido "persiste" en el momento del nacimiento, planteando "posibilidades de vida" nuevas." (BOURRIAUD, 2008:19)
} 
Sob o panorama de uma história ocidental na qual nos localizamos, na maioria das vezes, as transformações entre os séculos XIX e XX, os estudos da física, da matemática e a produção de pensamentos que discutem princípios e qualidades que se manifestam em dimensões cósmicas e cotidianas, ampliam o nosso acesso a conhecimentos práticos, teóricos, fenomenológicos, científicos, xamânicos, religiosos, místicos e zen.

Essa virada de século viu surgir ainda mudanças que alteraram profundamente as noções de tempo e espaço. Os referencias se dispersaram de um ponto de vista estável e fixo e provocaram o acionamento do olhar em diferentes direções. A multiplicação de percursos, de pontos de vista, as experiências temporais e a aproximação de lugares gerou uma série de transformações que problematizaram modelos, conceitos canônicos e determinações científicas.

Nietzsche irá falar sobre o fim do absoluto e Einstein afirmará que tempo e espaço são relativos. A desestabilização de pontos fixos de observação redefinirão nossa localização espacial em termos até mesmo planetários. Fomos lançados no espaço, passamos a interagir com galáxias, planetas, estrelas e uma infinidade de pessoas e objetos. Não estamos sozinhos e tão pouco somos ativos diante da passividade do universo. As coisas nos movem, nos observam e é sob essa perspectiva difusa e complexa que criamos relações, movimentos e paradas.

A relação entre saberes multiplica as formas de conhecimento e favorece a produção de diálogos que levarão em consideração diferentes aspectos e qualidades que se cruzarão em abordagens transdisciplinares. Uma dimensão experimental passará a orientar, sobretudo, o pensamento e a produção de arte a partir das transformações sociais e filosóficas que marcam essa passagem do século XIX para o XX. A multiplicação e a abertura, implícitas nas abordagens experimentais, irão sugerir novos encontros, a descoberta de trajetos inusitados e a possibilidade de trânsito livre entre os mais diversos referenciais.

Entretanto, ao mesmo tempo em que conquistamos liberdade para experimentar novos sentidos e criar novas condições de vida e percepção, somos imersos em programas de computador, nos tornamos dependentes de ferramentas que encurtam cada vez mais as distâncias e fazem o tempo disparar. Somos engolidos por grandes estruturas comerciais e reagimos bem quando, ao invés de pensar, somos convidados a imersões que agem na repetição de padrões e comportamentos. O corpo se afunda, se encurta diante de monitores, de informações que embaralham os pensamentos e paralisam possibilidades de ação no mundo.

O ritmo frenético das notícias que chegam pelas mais variadas mídias e o bombardeio diário de catástrofes geram uma trama apocalíptica que age em nossa percepção mais sutil e 
dificultam a produção de pensamentos críticos capazes que alterar nossas realidades e as situações que criamos.

A circulação rápida de informações gera relações automatizadas com o tempo e a repetição de percursos conhecidos. Aquilo que é sensível e frágil é inibido em nome de experiências espaciais e temporais previamente definidas. Fazemos o previsível e fazemos mais em menos tempo. Corremos, desviamos das falhas, aceitamos o que os sentidos já conhecem e geramos ciclos diários com durações e tempos parecidos.

Enquanto o conhecimento se expande o corpo se comprime entre inúmeras tarefas cotidianas. Deixamos de dançar, de pensar com músculos, ossos e articulações. Seguimos os mesmos percursos, utilizamos os trechos mais curtos, concluímos uma sucessão de tarefas diárias, respondemos e-mails, mensagens, controlamos o tempo em tabelas, planilhas, nos orientamos pelas imagem que criamos de nós mesmos e dos outros em publicações em redes sociais, olhamos o cotidiano condicionados pelos recortes que ficariam bem nas próximas publicações no facebook e deixamos de observar as linhas frágeis, porosas e contraditórias que contornam nossa existência.

Insistimos nas mesmas ideias, reproduzimos discursos que foram fundamentais em outros contextos, defendemos pontos de vista unilaterais, criamos verdades que possam nos reconfortar diante da complexidade da vida e dos eventos e ignoramos, muitas vezes, a fragilidade, as variações, as contradições e as falhas que incentivam a geração de novos referenciais no processo de ser e estar no mundo.

Ao ignorarmos nossa condição precária e transitiva esquecemos de nos observarmos sob uma perspectiva espacial mais ampla, esquecemos do entorno, dos contextos, da nossa relação com o meio, com as variações ambientais e dos sistemas de causa e efeito a que estamos sujeitos. Deixamos para amanhã tarefas que poderiam auxiliar na construção de novas relações com pessoas em geografias próximas e distantes, com paisagens cotidianas, com rios, florestas e recursos naturais que se esgotam diante de nossa indignação e de alguns breves comentários no facebook.

E se parássemos? E se suspendêssemos os passos que marcam esses trajetos acostumados? Novas paisagens são produzidas quando observamos novamente e com atenção as dinâmicas que se manifestam em grandes e pequenas escalas. Um passo atrás, a suspensão e a observação da arquitetura, da trama que compõe nossos ambientes e a analogia percebida nas teias costuradas pelas aranhas. A estrutura frágil e flexível que permite deslocamentos. Os vazios, as estruturas vazadas, aquilo que se mostra e aquilo que some enquanto crio novos vínculos, questionamentos e percepções. Um emaranhado complexo no qual o olhar vê o topo 
de uma montanha e logo cai abruptamente tocando novas geografias. A flutuação e os giros que posicionam os pés em intervalos que fazem oscilar os sentidos.

A continuidade e a ampliação dos conceitos que envolvem a performance, a ação e seus desdobramentos trazem consigo as noções de teatralidade e performatividade - operadores para leituras críticas que geram as mais variadas articulações artísticas. A desestabilização e a abertura de conceitos ganha destaque e passa a fundamentar experimentos na produção de arte. Aquilo que a primeira vista manifestava-se como lugar estável e livre de perturbações que fazem oscilar as possibilidades de abordagem de um evento, aparece agora como lugar em expansão, como ambiente que se precipita em diferentes direções e troca com os mais variados referenciais.

É nesta produção de tremores, colisões e coalizões que esse trabalho se propõe observar as teatralidades contemporâneas sob um ponto de vista espacial. O espaço será investigado a partir de princípios como instabilidade, troca, oscilação e multiplicação de referenciais, o que coincide com um olhar sobre as relações entre corpo e ambiente como possibilidade de geração de pensamentos. A construção de paisagens frágeis, prevista por tais qualidades ou condições, gera lugares que se manifestam em dinâmicas e relações espaciais.

Explorar espacialidades, limites, sentidos e a possibilidade de novos olhares e relações com o mundo é incentivar novas distribuições, é reorganizar e inaugurar novos modos de existir. Movimentos que escapam de suas trajetórias colaboram com a manifestação do imprevisível, do acaso e de perturbações que acionam qualidades que confirmam o aspecto dinâmico e relacional dos eventos artísticos. E é nesse contexto, que prevê desvios e constantes mudanças de perspectivas, que regras, padrões e referenciais instituídos são colocados em questão.

Os esquemas formais e pautados em equações estáveis dão lugar a uma série de dinâmicas que se manifestam em ações artísticas dependentes de relações, encontros e ativações que as colocam no mundo como vibração e acontecimento.

Se observarmos as práticas artísticas contemporâneas, mais do que "formas" deveríamos falar de "formações", o oposto de um objeto fechado em si mesmo por um estilo ou uma assinatura. A arte atual mostra que só há forma no encontro, na relação dinâmica que mantém uma proposta artística com outras formações, artísticas ou não. (BOURRIAUD, 2008:22, tradução nossa)².

\footnotetext{
2 Texto original: "Si observamos las prácticas artísticas contemporáneas, más que las "formas", deberiámos hablar de "formaciones", lo opuesto a un objeto cerrado sobre sí mismo por un estilo o una firma. El arte actual muestra que sólo hay forma en el encuentro, en la relación dinámica que mantiene una propuesta artística con otras formaciones, artísticas o no." (Bourriaud, 2008:22)
} 
O que presenciamos hoje é um diálogo intenso que aborda o fenômeno artístico sob o ponto de vista do conhecimento, da percepção e da produção de novos sentidos. A produção de arte surge, neste contexto, como campo de negociações no qual se cruzam linguagens, ideias, intensidades e olhares que agem sobre e no mundo. Ainda nas palavras de Bourriaud:

(...) A forma de uma obra de arte nasce de uma negociação com o inteligível. Através dela, o artista inicia um diálogo. A essência da prática artística residiria assim na invenção de relações entre sujeitos; cada obra de arte em particular seria uma proposta para habitar um mundo em comum e o trabalho de cada artista um feixe de relações com o mundo, que por sua vez geraria outras relações, e assim sucessivamente até o infinito. (BOURRIAUD, 2008: 23, tradução nossa) ${ }^{3}$.

Esse campo amplo, complexo e heterogêneo que é gerado coincide com uma explosão que reformula ordens espaciais e ambientais. A produção em arte é capaz de criar espaços que correspondem a dinâmicas nas quais os cálculos exatos e previsíveis resultam sempre em variações, acasos a aleatoriedades.

Os lugares estabelecidos, controlados, separados e sujeitos às regras de produção, de compra, de venda e que tendem a regular os sentidos são transformados, durante uma experiência artística, em situações que desafiam o pensamento, a crítica e a percepção.

\begin{abstract}
A atividade artística se esforça em realizar modestas ramificações, abrir algum passo, colocar em relação níveis da realidade distanciados uns dos outros. As famosas "autopistas da comunicação", com seus pedágios e suas áreas de descanso, ameaçam impor-se como o único trajeto possível de um ponto ao outro do mundo humano. Se a autopista permite efetivamente viajar mais rápido e eficientemente, também tem como problema transformar seus usuários em meros consumidores de quilômetros e seus produtos derivados. Frente à mídia eletrônica, aos parques de diversão, aos locais de entretenimento, à proliferação de formatos compatíveis de sociabilidade, nos encontramos pobres e desprovidos, como um rato de laboratório condenado para sempre a um mesmo percurso em sua gaiola, entre pedaços de queijo. $\mathrm{O}$ sujeito ideal da sociedade de figurantes estaria então reduzido à condição de mero consumidor de tempo e espaço. (BOURRIAUD, 2008: 7, tradução nossa) ${ }^{4}$.
\end{abstract}

\footnotetext{
${ }^{3}$ Texto original: “(...) la forma de una obra de arte nace de una negociación con lo inteligible. Através de ella, el artista entabla un diálogo. La esencia de la práctica artística residiría así en la invención de relaciones entre sujetos; cada obra de arte en particular sería la propuesta para habitar un mundo en común y el trabajo de cada artista, un haz de relaciones con el mundo, que generaría a su vez otras relaciones, y así sucesivamente hasta el infinito." (Bourriaud. 2008: 23)

4 Texto original: "La actividad artística se esfuerza en efectuar modestas ramificaciones, abrir algún paso, poner en relación niveles de la realidad distanciados unos de otros. Las famosas "autopistas de la comunicación", con sus peajes y sus áreas de descanso, amenazan con imponerse como unico trayecto posible de un punto a otro del mundo humano. Si la autopista permite efectivamente viajar más rápido y eficazmente, también tiene como defecto transformar a sus usuarios en meros consumidores de kilómetros y de sus productos derivados. Frente a los medios electrónicos, los parques de diversión, los lugares de esparcimiento, la proliferación de formatos compatibles de sociabilidad, nos encontramos pobres y desprovistos, como rata de laboratorio condenada para siempre a un mismo recorrido, en su jaula, entre pedazos de queso. El sujeto ideal de la sociedad de figurantes estaría entonces reducido a la condición de mero consumidor de tiempo y de espacio." (Bourriaud, 2008:7)
} 
A arte contemporânea produz e sugere dinâmicas que pretendem provocar os sentidos e colocar em movimento ângulos de observação fixos. E é assim que produções e procedimentos de arte se afirmam como processos em andamento, como eventos abertos e temporários nos quais os movimentos de interação entre corpos, objetos, coisas e lugares geram ambientes, espaços que se manifestam no cruzamento de forças efêmeras e oscilatórias.

Toda essa movimentação, no entanto, faz parte de um diálogo intenso que a arte vem tecendo com a filosofia, com estudos culturais, com a literatura e com campos outros do conhecimento. Essa trama entre conceitos e respiros que acionam pensamentos físicos e materiais entende a arte como um campo processual e investigativo que não se encerra em modelos e regras de representação. O fenômeno da arte atravessa as limitações impostas por escolas, métodos e regulamentações e se afirma como processo humano que trata do olhar, da observação, do pensamento, da percepção e da criação de espacialidades. Essa função ontológica que trata do modo de ser e estar no mundo está entrelaçado com o processo de conhecimento humano. E esse é um processo longo e sem origem definida, que cruza caminhos errantes, que se organiza e se desorganiza no percurso, entre culturas, idiomas, corpos e peles.

E é deste modo instável e temporal que muitos trabalhos e procedimentos de arte se apresentam, sobretudo a partir do início e meados do século XX. A arte se lança ao desafio de gerar e promover campos dinâmicos nos quais as ações superam regras e esquemas de representação. E é nesse contexto que a linguagem se afirma como ato e não mais como campo estático e descritivo, como afirmaria o filósofo John Langshaw Austin em seus estudos e teses sobre os atos da fala.

O filósofo inglês John Austin ${ }^{5}$ (1911-1960) é responsável por importantes considerações sobre a linguagem como ação. O autor Paulo Ottoni (2002) ${ }^{6}$ afirma que "foi Austin quem introduziu de maneira definitiva os conceitos de performativo, ilocucionário e de ato da fala". Há um desdobramento desses conceitos, nas colocações de Austin, que contribui para abordagens sobre a linguagem para além de limitações institucionais e normativas. Os conceitos de ilocucionário e atos da fala aparecem diretamente relacionados com o conceito de performativo.

\footnotetext{
5 Em 1955, o filósofo inglês J. L. Austin apresentou suas famosas palestras "William James Lectures" na Universidade de Harvard. Essas conferências, publicadas em 1962, um ano depois de sua morte, marcaram a história da filosofia contemporânea com seu termo mais conhecido, o performativo.

${ }^{6}$ No artigo: "John Langshaw Austin e a visão performativa da linguagem." Paulo Ottoni, 2002. Texto disponível no link: http://www.scielo.br/scielo.php?pid=S0102-44502002000100005\&script=sci_arttext\#nt. Acesso em novembro de 2015.
} 
Suas discussões sobre performatividade propõem questionamentos sobre determinações que separam e geram cisões entre lugares e instâncias. Os postulados de verdadeiro e falso, por exemplo, são fortemente questionados pelo autor. Austin, em suas considerações sobre o performativo, dá ênfase às tensões, aos vínculos e às trocas que superam as abordagens dicotômicas que separam objeto e sujeito. Ottoni comenta:

a performatividade adquire, então, um estatuto único ao ser analisada no interior dos estudos da linguagem. A cisão sujeito e objeto não se sustenta mais numa visão performativa; ela não possibilita estabelecer uma fronteira entre o "eu" e o "não eu". Esta característica na argumentação de Austin é o lugar de confronto que possibilita redimensionar, através da fusão de seus "procedimentos filosóficos" e de suas "técnicas de análise da linguagem ordinária", de modo decisivo a relação sujeitoobjeto, nos estudos da linguagem. (OTTONI, 2002:6)

Essa fusão entre sujeito e objeto analisada por Austin a partir dos atos da fala dizem respeito a uma "análise que Austin fez sobre a sensação, sobre a percepção humana", como afirma Paulo Ottoni (2002).

Mais do que constatar e produzir afirmações, sua "visão performativa" se propõe observar e discutir as dinâmicas e movimentos que se manifestam na linguagem. $\mathrm{O}$ enunciado performativo, deste modo, se afasta das constatações sobre aquilo que é "verdadeiro" e aquilo que "falso". Ele não é nem um nem outro, mas antes a possibilidade de realizar ação. Sobre esta questão, Otonni fala sobre a abordagem proposta por Austin: "Nos enunciados constativos há, "filosoficamente", um tipo de referência; já nos enunciados performativos, esta mesma noção "fillosófica" não pode ser aplicada, porque estes últimos, segundo ele, realizam uma ação, e aqui a referência é de outro tipo." (OTTONI, 2002:7)

A tese de Austin sobre os enunciados performativos e os atos da fala colaboraram de modo decisivo com os estudos sobre a linguagem em sua condição ativa. Dizer é agir, afirmaria Austin. Ao colocar em pauta a ação, o filósofo apresenta uma das questões fundamentais que orientará novos rumos para teorias e práticas que envolvem estudos sobre a linguagem, sobre o discurso e sobre aspectos implícitos nos atos. Uma das chaves de acesso está dada: a ação.

Surge um novo paradigma teórico que considera a linguagem como ação, como forma de atuação sobre o real, e portanto de constituição do real, e não meramente de representação ou correspondência com a realidade. O ponto central da concepção de Austin e sua principal contribuição à filosofia da linguagem parece-me ser a ideia de que a linguagem deve ser tratada essencialmente como uma forma de ação e não como representação da realidade. (FILHO, Danilo Marcondes de Souza. Prefácio do livro "Quando dizer é fazer, palavras e ação". J.L. Austin, 1990:10,11) 
Otonni (2002:8) fala sobre a ação, em Austin: “Ação, para Austin, tem um significado muito preciso pelo fato de ser um dos elementos constitutivos da performatividade. Para ele, a ação é uma atitude independente de uma forma linguística: o performativo é o próprio ato de realização da fala-ação.” A noção de ação favorecerá importantes considerações sobre o termo "performativo" em suas colocações. A autora Juliet explica:

A partir de Austin, nós aprendemos que, ao proferir uma elocução performativa, você está realizando uma ação, ou talvez executando a ação fundamental em uma série de outras ações (não-verbais) que têm consequências reais no mundo. A linguagem pode conceder o perdão, bênçãos, liberdade, cidadania e ofender. Em outras palavras, a linguagem pode executar uma realidade; atos de fala. (RUFFORD, 2015: 35 e 36, tradução nossa $)^{7}$.

O termo "performativo", deste modo, surge no contexto da filosofia da linguagem e aborda os atos da fala como ações que não se limitam às descrições. Austin discorre sobre a fala, sobre os atos que se sobrepõem aos sistemas descritivos ou mesmo sobre as ações que superam composições ou noções metafóricas. Aquilo que é dito age no mundo e produz ações que tanto podem se articular em estruturas que estabilizam discursos e sentidos quanto podem provocar cisões no modo de agir e criar relações.

É importante apontar ainda aproximações entre a "visão performativa" de Austin com a percepção humana, o que favorece um olhar sobre as múltiplas possibilidades de abordagem das colocações do autor, assim como das dinâmicas que estão em jogo em sua noção de ação e performatividade. Os fatores que se entrelaçam nas considerações de Austin demonstram, de acordo com Paulo Ottoni (2002:10), "a abrangência e a complexidade das reflexões austinianas e podem servir para discutir e explicar, ao mesmo tempo, as abordagens diferentes, conflitantes e contraditórios das propostas de Austin."

Neste contexto e de acordo com premissas colocadas pela noção de performatividade, a produção de arte contemporânea parece se aproximar de um dizer que se imprime no mundo através de atos que localizam a linguagem e o discurso em zonas de trepidação nas quais cenários monótonos ganham tonalidades e dinâmicas. Os atos decorrem no tempo e se aderem às variações espaciais. Atos são ações e não a representação ou descrição de imagens que remetem ao que decorre em um tempo e espaço específico. Os atos criam realidades porque acionam e gera tensões no presente.

\footnotetext{
7 Texto original: "From Austin we learnt that, in uttering a performative, you are performing an action, or perhaps performing the primary action in a series of other (non-verbal) actions that have real consequences in the world. Language can bestow forgiveness, blessings, freedom, citizenship and injuries. In other words, language can perform a reality; speech acts." (Rufford, 2015: 35 and 36)
} 
A performatividade aparece aqui como dinâmica, como ação comprometida com a revelação de oscilações e indeterminações que estão implicadas na manifestação da linguagem como ligação com o mundo. Aquele que diz, aquele que age e os múltiplos agentes que constituem essa rede de relações são agora vozes múltiplas e olhares transitórios que irão se formar nos encontros, nos cruzamentos e dispersões que se manifestam em sujeitos e ambiente em constante processo de transformação.

Estudos sobre a linguagem como atos nos quais se cruzam uma profusão de vozes, sensações, memórias, perspectivas sociais e entonações, reverberam na abertura de conceitos sobre o corpo, sobre o sujeito e sobre o espaço, por exemplo, e fazem emergir importantes investigações sobre o indeterminado, sobre aquilo que está por se fazer, sobre o inacabado e aquilo que está aberto às interferências do meio. Entre os autores que se dedicaram ao estudo da linguagem e de forças que surgem provocando alterações nas falas, nos discursos e nas experiências espaciais, está Michael Foucault.

A noção de Heterotopia, apresentada pelo autor, na qual a produção de espaços está associada à dinamização e ao cruzamento de camadas visíveis e invisíveis que se sobrepõem e geram intensidades e deslocamentos da percepção, dialoga diretamente com o objeto desta pesquisa. $\mathrm{O}$ acionamento de forças e os atos que se manifestam nas relações entre diferentes elementos e aspectos se referem à ação e à criação de campos performativos, utilizando-me da noção apresentada por Austin.

Esse emaranhado complexo no qual diferentes elementos e qualidades se relacionam, evidenciam vínculos que se apresentam em territórios expansivos e relacionais.

Um campo ou uma perspectiva relacional é gerada. As coisas se movem e se alteram mutuamente. Os pontos de vista se multiplicam, se descentralizam e passam a percorrer órbitas instáveis e dinâmicas. A estabilidade é agora condição temporária ou mesmo ilusória para aqueles que pretendem apreender discursos, gestos e palavras prontas e acabadas.

Nesse movimento difuso e sem acesso determinado de entrada ou saída a relação ganha força, se manifesta em sua potência e como ato que gera e dilui formas. É na relação também que a recepção, no contexto das artes, passa a ser campo de grande especulação por parte de artistas e teóricos.

As bordas do evento artístico tornam-se finas, porosas e o espectador passa a atuar nesse campo inclusivo no qual os mais diversos elementos interagem entre si formando paisagens frágeis, sutis e temporárias. Condições temporais e ambientais prevêem um olhar que circula, que percorre o acontecimento da arte em diferentes direções, níveis e intensidades. E é nesse 
contexto que a presença do espectador ganhará destaque e se transformará em alvo de interesse nos mais variados experimentos.

Relações entre obra e espectador, discussões estéticas, considerações sobre performatividade, dinâmicas e a construção de espacialidades são algumas das questões suscitadas pelo pensamento e prática da arte sobretudo a partir de meados do século XX. Um campo instalativo e performativo é inaugurado na ativação de relações entre coisas, pessoas, arquiteturas, objetos etc. A arte perde o estatuto de manifestação autônoma, como desejaram renascentistas e modernistas, e passa a acontecer no entre, nos intervalos por onde respiram formas, percepções e sentidos - na manifestação de espacialidades.

A oscilação das bordas do evento e a absorção de interferências fazem com que as relações entre arte e vida passem também a ser colocadas em questão. O que da arte se espalha para a vida e o que da vida transborda para a arte? Não seriam arte e vida manifestações de um mesmo processo em andamento?

Neste ponto, discussões sobre a experiência estética promovem reflexões sobre o olhar e sobre as relações levando em consideração o caráter aderente dos processos de interação com o entorno. A identificação dos limites entre arte e vida fica prejudicada quando lançamos um olhar sobre os eventos como processos e movimentos que dizem respeito aos sentidos e à percepção. A filosofia, e mais especificamente a estética, enquanto disciplina filosófica voltada às questões do fenômeno e da produção de arte, fomenta discussões sobre o exercício artístico vinculado ao pensamento e a construção de conhecimento.

A arte se apresenta como um campo no qual ressoam pensamentos, reflexões e ações amparadas por considerações filosóficas e diálogos com campos outros do conhecimento que auxiliam no mapeamento e na construção de uma análise mais abrangente e dialógica sobre os procedimentos artísticos.

E é sob essa perspectiva que propostas e procedimentos de William Forsythe passam a compor o escopo principal e orientador das questões levantadas por este trabalho.

William Forsythe, coreógrafo americano que viveu e trabalhou na Alemanha por trinta anos, produz hoje uma ampla variedade de projetos que incluem instalações, filmes e estudos do movimento a partir de notações virtuais. O profundo interesse do artista por princípios fundamentais de organização espacial o levaram a produzir trabalhos como os Objetos Coreográficos, que exploram conceitos e potencialidades presentes nos intervalos entre corpo e espaço.

Uma pergunta: Como cheguei em William Forsythe? 
Das artes cênicas para as artes visuais e para a dança percorro um trajeto que coincide com as minhas investigações como artista e pesquisadora. O olhar percorre e cria espaços e o corpo tateia novos lugares. Intervalos que alteram referenciais e me estimulam a um jogo infinito de descobertas e novas perspectivas. O desmoronamento de certezas e o surgimento de linhas invisíveis que propõem novos pontos de fuga, a observação percorrendo trajetos imprevisíveis.

Aventurei-me em desenhar com linhas e pontos largos paisagens possíveis para o acontecimento teatral. Com esse propósito, me afastei do teatro para experimentar referenciais outros que talvez justificassem a minha escolha pelo exercício cênico. A expansão do olhar, o encontro com novas texturas e a criação de novos esboços e lugares me possibilitou redesenhar e repensar o espaço teatral. A experiência do ponto de fuga. Eu como o ponto. Não o ponto de fuga das narrativas lineares, das figurações, representação, não aquele do fundo do quadro, não aquele da perspectiva, mas aquele que me lança de um lugar para o outro e que me permite observar e capturar, mesmo que parcialmente, as linhas que compõem o ambiente por onde transito.

Estudei artes visuais, filosofia, circo, dança, línguas, atuei, desenhei, apaguei tudo, escrevi e nesses trajetos experimentei o ambiente teatral em diferentes situações. $\mathrm{O}$ teatro como a impressão do corpo na arquitetura, como o trânsito entre estados e como desenhos livres que se esboçam entre diferentes linguagens.

Tais informações pontuam, definem e localizam com maior precisão o objeto desta pesquisa. O foco de interesse está no deslocamento, na transição e na utilização de novos referenciais para a prática da arte. O que desperta a minha curiosidade nos trabalhos de Forsythe, e sobretudo na série Objetos Coreográficos, coincide com essa experiência radical de desestabilização de padrões e conceitos instituídos. A ruptura não só com as regras e com os modelos do balé, mas com a instituição e com o suporte vinculado à linguagem da dança, definem uma alteração fundamental no pensamento e na prática de William Forsythe. E é justamente por essa via que transitam as problemáticas e os interesses deste estudo.

Escrevia ainda a minha dissertação de mestrado quando entrei em contato com textos que tratavam da produção de William Forsythe. Houve um interesse imediato pelas práticas e pensamentos propostos pelo artista. A observação da dança sob a perspectiva de organizações e formações ambientais sugere um alargamento de conceitos e a investigação de linhas espaciais que se formam entre corpo e espaço. Esse é um assunto que sempre me despertou muita curiosidade e que passou a ser meu objeto de estudo em pesquisas práticas e teóricas. Como produzo espaços? Como que a prática artística age na movimentação da minha 
percepção? Por que os trabalhos com arte, sejam eles ações que desenvolvo como artista ou propostas que assisto ou experimento, como espectadora-participante, tendem a redirecionar o meu olhar e gerar sustos que inauguram experiências sempre novas até mesmo quando percorro orientações já conhecidas?

Li textos, passei a assistir a alguns vídeos e a visitar o site da The Forsythe Company com uma certa frequência. A diversidade dos projetos e propostas de Forsythe me chamou a atenção. A dança aparecia em lugares improváveis, deslocava-se de seus referenciais e percorria trajetos que se articulavam ora no corpo de dançarinos, ora no corpo de visitantes de museus e bienais, ora em corpos de passantes em lugares públicos e ora na intersecção entre lugares e situações que geravam diferentes possibilidades para as relações entre obra e espectador.

Aos poucos, fui entrando em contato com o universo complexo e heterogêneo proposto Forsythe. Em junho de 2013 tive a oportunidade de conhecer alguns de seus trabalhos em Berlim, no Berliner Festspiel. Assisti a algumas apresentações da The Forsythe Company, conheci algumas instalações e foi também nesta ocasião que compreendi aquilo que despertava meu interesse em suas propostas: o salto, a suspensão do corpo e dos sentidos e a variação da percepção de mim mesma e do espaço. Essa experiência aconteceu quando conheci o trabalho White Bouncy Castle, que foi instalado no parque Natur-Park Schöneberger Südgelände. A decisão de focar esta pesquisa nos Objetos Coreográficos e em dinâmicas que desafiam a percepção surgiu desta experiência prática. $\mathrm{O}$ meu corpo em ação e a descoberta, em meu próprio corpo, de princípios que vinculam corpo e espaço foi fundamental para o recorte aqui proposto.

A experiência física dos Objetos Coreográficos me fez pensar ainda sobre a posição do espectador e as intersecções espaciais que ampliam a zona de ação de um evento artístico. Questões e problemáticas que destaquei em meu projeto de pesquisa ficaram mais claras quando conheci e interagi com o Objeto Coreográfico White Bouncy Castel. Como experimento princípios da dança sem os referenciais estereotipados da própria dança? Como me relaciono com o espaço e como construo espaços? Como que uma estrutura ou um objeto pode provocar movimentos e a transformação de estados em meu corpo? Como percebo o meu corpo?

O contato com os trabalhos de Forsythe, neste ano de 2013, me fez perceber problemáticas que me parecem fundamentais para o pensamento sobre a produção de arte contemporânea. A observação de fenômenos sob os mais variados pontos de vista favorece a investigação de conhecimentos que não se fundamentam sob bases rígidas e estáveis. $\mathrm{O}$ 
pensamento ganha texturas físicas, se manifesta em pinturas, instalações, textos e em nossas relações com o mundo.

Desde meados de 2013 que mantenho um contato constante com os trabalhos de William Forsythe e com um de seus principais pesquisadores, o professor Gerald Siegmund. Livros, textos e materiais audiovisuais contribuíram com o mapeamento de procedimentos e com a construção de pensamentos sobre a prática do coreógrafo. Entretanto, foi em abril de 2015, depois de acompanhar o processo de remontagem do trabalho Kammer Kammer, e de uma conversa com o Forsythe que as peças desse grande quebra-cabeças revelaram qualidades e aspectos de um desenho que venho rabiscando desde o início desse processo de pesquisa. Mesmo partindo de um recorte, em meu projeto de pesquisa, que já previa uma abordagem espacial da produção de Forsythe, o encontro com as qualidades que hoje estruturam e fundamentam este trabalho só foi possível após o estágio com a The Forsythe Company durante a remontagem do espetáculo Kammer Kammer, no período de março a abril de 2015.

A observação de elementos e aspectos que surgem em suas peças e que persistem nos Objetos Coreográficos foi fundamental para o recorte aqui apresentado. O espaço que surge nos procedimentos de Forsythe é múltiplo, descentralizado, escorregadio e composto por camadas complexas que promovem interações entre corpo e espaço. O que vemos como procedimento de trabalho no contexto de suas peças com bailarinos é uma das variações possíveis de arranjos espaciais temporários e frágeis que abordam a dinâmica e a mutabilidade dos eventos.

O que Forsythe propõe na relação entre os bailarinos é uma espécie de configuração espacial móvel na qual a noção de dança, coreografia ou seja lá o que for, já que o nome ou a classificação do evento não tem papel de destaque em suas práticas, se manifesta como um jogo entre elementos, matérias e qualidades que se atualizam constantemente. O corpo gira ao mesmo tempo em que novas superfícies se tornam palpáveis e fugidias. O espaço todo se move e com o ele o olhar experimenta novas direções e produz novos sentidos.

Uma questão que se coloca na análise e estudo dos Objetos Coreográficos é a escolha de um procedimento de abordagem que dê conta de aspectos físicos e fenomenológicos que estão implicados na maioria dos trabalhos que compõem essa produção.

E foi a partir daí que optei por trazer para este estudo referencias da minha prática como artista. Percebi contatos entre inquietações minhas e problemáticas que surgiram nas relações que fui construindo com os Objetos Coreográficos. A percepção, a presença do espectador e as forças que agem entre corpo e espaço são assuntos que se desdobram em pensamentos que 
procuro investigar em minhas práticas como artista e educadora. De que modo a observação e a experiência de qualidades e condições espaciais pode interferir em meu campo perceptivo? De que modo a educação estética pode auxiliar na construção de percursos autorais e singulares? Em quais condições a arte pode se apresentar como possibilidade de produção de conhecimento? Que conhecimentos são esses produzidos e acessados pelo meu corpo?

As perguntas são muitas e esse trabalho, mesmo que se ocupe em abordá-las, é uma entre tantas possibilidades de aproximação das problemáticas e assuntos e aqui identificados.

Outro dado importante em relação aos Objetos Coreográficos é que nem todos os trabalhos são propostas de interação física destinadas ao espectador. Alguns dos objetos se apresentam como filmes, projeções e objetos dispostos em espaços expositivos. Essa característica confirma o caráter investigativo de Forsythe, sobretudo no contexto dos Objetos Coreográficos.

O objetivo desta pesquisa é investigar aspectos das espacialidades propostas por William Forsythe em diferentes projetos, propostas e esquemas organizacionais. O foco de investigação é a localização de fundamentos e princípios instalativos que surgem ao longo de sua trajetória e que se reafirmam na série de trabalhos intitulada Objetos Coreográficos.

Embora exista uma tensão constante no que se refere aos inúmeros desdobramentos possíveis do conceito de espaço, opto por uma noção que aproxima a criação de espaço de uma condição material e imagética. A criação de espaço como a produção de ambientes e não como o surgimento de áreas delimitadas é um dos fatores determinantes nas práticas e experiências artísticas contemporâneas.

Deste modo, a compreensão de espaço surge como possibilidade de criação de novos mundos, percepções, mobilizações e produções de experiências que não estão condicionadas ao surgimento de uma fábula ou de uma história. O ideia de espaço como lugar em expansão contribui para a análise e reflexão das produções de arte hoje. Em que medida o espaço, como potência de criação e inventividade pode ser investigado?

A abordagem de Forsythe e suas provocações espaciais favorecem ainda um olhar sobre a educação estética no contexto de formação do artista. De que modo as condições instalativas abordadas por Forsythe auxiliam na reconfiguração de olhares e relações com o entorno? E de modo essas novas relações podem reverberar nos processos de produção artística? Como que essa espacialidade dinâmica pode contribuir com a construção de pensamentos que acontecem no cruzamento de referenciais? Como gerar articulações entre conhecimentos práticos e teóricos a partir de uma abordagem espacial que prevê respiros, frestas, passagens e prolongamentos ao invés de bordas definidas? 
Referenciais das artes visuais e abordagens da arquitetura, por exemplo, que localizam o espaço na relação entre materiais, elementos e corpos, são alguns dos estímulos que colaboram com o mapeamento, a reflexão e a visualização das principais questões que serão abordadas neste estudo. A noção de instalação, o conceito de ambiental e os termos paisagem e desenho aparecerão como indicadores de lugares móveis, de linhas porosas e camadas que se justapõem em intensidades e composições que se manifestam no cruzamento e na inauguração de espaços.

Esta pesquisa está estruturada em seções que pontuam aspectos ou indicações espaciais que aparecem em diferentes contextos da produção de Forsythe.

Desvios é o nome da primeira seção. Neste texto de abertura o espaço é anunciado sob o ponto de vista de puxões e empurrões, de tonalidades, cores, atmosferas e sons habitados com os sentidos. Nesta seção de abertura, quem nos apresenta a condição espacial que fundamenta este estudo sou eu, artista-pesquisadora que cruza referenciais práticos e teóricos em investigações que se expandem e produzem pensamentos. A ideia é apresentar o trabalho sob o ponto de vista do ato de pesquisar, de rabiscar deslocamentos que solicitam incursões físicas e intelectuais como modo de investigar e produzir conhecimento. $\mathrm{O}$ assunto desta pesquisa se apresenta na matéria, nas palavras que fogem de seus lugares formatados por modelos acadêmicos e se arriscam em entonações fora do tom. Habitar tem aqui a conotação de imprimir e percorrer marcas que se alastram pelo corpo e perfuram o chão em trepidações que modificam a fundação do solo.

Em seguida, na seção Passagens, é apresentada a minha primeira experiência de contato com um trabalho de William Forsythe, o White Bouncy Castle. Nesta seção trago à tona condições e considerações que fundamentam este trabalho. As órbitas às quais a percepção é lançada e a descoberta do espaço em minha própria fisicalidade me levam a uma pesquisa mais detalhada do percurso artístico e dos procedimentos de William Forsythe, que aparecerão na seção seguinte.

Linhas é a seção que traz uma biografia de Forsythe ao mesmo tempo em que ressalta o seu interesse por mudar as coisas de lugar e gerar indeterminações que ampliam o campo de visão sobre o que um acontecimento é ou pode vir a ser. O fechamento do Balé de Frankfurt, no qual atuou como coreógrafo por vinte anos, e a criação da The Forsythe Company também são comentados nesta sessão. Essa seção pontua ainda o caráter processual e investigativo de Forsythe em sua atuação como diretor do Balé de Frankfurt e na transição para a formação da The Forsythe Company. A pesquisa, a mudança e os novos desafios marcam sua trajetória como coreógrafo e pesquisador do movimento interessado por estruturas espaciais frágeis e 
dinâmicas. Ao balé se somam práticas e abordagens que favorecem o estudo do movimento e de perspectivas espaciais.

A seção seguinte, Estruturas Vazadas, aborda o conceito de Heterotopia, de Michael Foucault, e analisa qualidades e condições que aparecem nos trabalhos Heterotopia, Kammer Kammer e Endless House. O trabalho Endless House, que acontece metade na Ópera de Frankfurt e metade no Bockenheimer Depot, inaugura uma variação espacial que dará destaque a presença e a construção de lugares nos quais obra e espectador experimentam possibilidades de encontro e aproximação. As relações entre diferentes estímulos e elementos apontam aspectos espaciais instalativos que serão observados em diferentes momentos de sua produção e, especialmente, nos Objetos Coreográficos.

Lugares em construção dá continuidade à observação de aspectos instalativos que ganham destaque nas propostas de Forsythe. A noção de instalação, as problemáticas que surgem nos diálogos da arte com as instituições e as propostas do coreógrafo em espaços públicos abordam problemáticas relevantes para a observação do fenômeno da arte hoje.

Em Formações temporárias abordo a crise da representação, fundamental nos procedimentos de William Forsythe, e apresento o surgimento de zonas instáveis e abertas a partir das experimentação de artistas como Hélio Oiticica e Lygia Clark, que se lançaram ao desafio de pensar e fazer arte a partir de pressupostos que entendem o campo artístico como lugar de conhecimento, descobertas e inauguração de espaços. A dinamização do espaço remete a discussões relacionadas às configurações espaciais e ao deslocamento do olhar, da figura estável presa no quadro para propostas que admitem e assumem o espaço expositivo como ambiente que vincula e relaciona obra e público. E é nessa conjugação da obra com o espectador que surgem as considerações sobre uma arte ambiental, que aparece tanto nas artes visuais, em projetos e programas de Helio Oiticica, por exemplo, como nas artes cênicas, com as propostas de expansão e interação com o público sugeridas por Richard Schechner. A presença física do espectador justifica as considerações abordadas nesta seção ao mesmo tempo em que fomenta as discussões seguintes sobre os Objetos Coreográficos de Forsythe.

Os trabalhos selecionados para a seção Suspensões pontuam a materialidade e aspectos que se manifestam na matéria, no corpo, na fisicalidade como estímulos que ativam faculdades perceptivas e promovem a experiência de pensamentos espaciais que acontecem sob uma perspectiva física e relacional. $\mathrm{O}$ que coincide com a ideia de suspender conceitos estabelecidos, suspender os sentidos acostumados e suspender o corpo em experiências físicas e espaciais inusitadas. Considerações do Minimalismo e a revisão de conceitos como Objeto e Coreografia corroboram para as reflexões sobre os Objetos Coreográficos. 
A seção Paragens, que fecha este trabalho e apresenta possibilidades de desdobramento e continuidade de investigação das questões aqui levantadas, aborda relações entre o tema desta pesquisa com a educação do artista contemporâneo. Apresento nesta seção final breves apontamentos sobre a educação estética sob uma perspectiva na qual corpo, espaço e percepção produzem possibilidades múltiplas de relação que implicam na ativação e no exercício do sensível.

Por fim, Reticências são as páginas conclusivas desta pesquisa nas quais apresento um olhar geral sobre o objeto deste estudo assim como considerações rápidas sobre o ato de pesquisar, de experimentar a pesquisa em diferentes relações e mudanças de lugar.

A importância deste trabalho reside nos diálogos e reflexões sobre a trama que aproxima e vincula diferentes linguagens e abordagens artísticas. A arte como campo de estudo, de conhecimento e investigação coincide com necessidades e interesses apresentados pela arte contemporânea. Este estudo pretende, deste modo, contribuir com reflexões sobre o espaço e o pensamento sobre a arte a partir de uma perspectiva que assume o pensamento como ação que se adere ao espaço e às ressonâncias do meio.

A construção de paisagens frágeis e temporais que levam em consideração as interferências do entorno são tema de um estudo que prevê incursões e cruzamentos entre referenciais práticos e teóricos.

A produção do texto deste estudo coincide com a tarefa de investigar acessos e passagens que solicitam movimentos ligeiros que flutuam entre articulações que me passam desapercebidas. Experimento qualidades que me auxiliam na construção de um pensamento sobre aspectos que destaco na propostas e produções de Forsythe. Para tanto, me lanço em uma rede, um lugar sem pontos fixos e com perspectivas difusas. Navego em teias e tramas que perturbam orientações como horizontal, vertical, dentro e fora. Aventuro-me por planícies que incorporam declives, mares e picos nevados. Experimento o acidental e modos de vincular que desconheço. 


\section{D \\ $\mathbf{E}$ \\ $\mathbf{S}$ \\ V \\ I \\ O \\ S}

Tudo começa com um TREMOR. O momento em que a terra se rompe e a pele se alastra percorrendo

DECLIVES e superfícies extensas. Abalos e choques que encurtam a respiração. $O$ corpo oscila e os pés flutuam em diagonais que cruzam fendas e janelas por onde brotam pequenas plantas. Há sempre uma brecha, um buraco exposto para o susto dos olhos. Lá onde vejo fragmentos de mim, montome de ponta à cabeça. A ausência é também aquilo que aperta no peito e escorre em lágrimas feitas de uma mistura densa que se dilui em sorrisos e palavras sussurradas.

A cor amarela e a propagação dos sons logo no início das estações. Acaju é tonalidade do fim de tarde. Sombras são aqueles pontilhados que apagam as figuras que meus olhos conhecem. É quando eu vejo a luz desaparecer e me desloco entre os vazios que pintam a parede. Uma árvore que se projeta imensa é também memória e resíduo da árvore plantada no jardim ao lado. Assim nascem as plantas que eu cultivo. Semeadas entre sustos e desvios do olhar, elas acolhem o meu corpo e alongam meus dedos. Apago o sol enquanto toco as estrelas. 
Tomo fôlego para assumir-me cambaleante, frágil e precária.

Desejo a segurança dos conceitos, a determinação de pontos de vistas, mas a desorientação é fascinante. $\mathrm{O}$ risco, a oscilação, estar e não estar, pertencer e plainar, criar e demolir instituições é um exercício que demanda abandonos e retomadas constantes. É lançar-se ao caos com a certeza de que novas orientações surgirão.

Viajando de trem os pensamentos correm. Campos inteiros onde me vejo dançando. $\mathrm{O}$ trem se desloca $\mathrm{e}$ giro entre plantações. Adoro registrar as paisagens amarelas e os desenhos simétricos das plantações alemães que percorrem o meu corpo. Desenho e meu corpo apaga. Fecho os olhos e já estou na próxima estação.

O olho do furacão, a trepidação da terra, as lavas em chamas. A onda que bate forte na encosta e faz o meu coração bater. O lugar da criação. A palavra. Doar palavras. Evocar sons e desenhar rascunhos. Doar o corpo e liberar a voz. Desprender-se de si em gestos leves e mínimos. Gritar. Ouvir sons distantes. Abrir a boca para deixar que circulem vozes ancestrais. $\mathrm{O}$ primeiro gesto. $\mathrm{O}$ peito aberto.

O mal estar, os pensamentos rarefeitos, o peito apertado e a respiração comprimindo os órgãos. Dilatar-se para ficar do tamanho de si deve ter a ver com romper limites físicos de ossos e órgãos. 
Lugar pequeno com pensamentos constantes me dá vertigem. Tomo fôlego e atravesso pontes. Um chão de ideias para pisar e pequenos tremores para perceber o novo. Ler, ouvir, ler, aulas, escrever, anotar tantas palavras, alongar, girar, ficar de cabeça para baixo, experimentar o ar, subir, alterar perspectivas, ver do alto, pisar o chão, soltar-me. Baixinho reconheço forças e lugares por onde meu corpo quer passar.

Oriento-me por instruções precisas. Percorro trajetórias previamente definidas para escorregar em labirintos imprevisíveis. Crio estratégias para me deslocar por diferentes mapas, contrastes e texturas. Crio saídas para produzir em mim lugares com matizes Suaves, linhas foscas e palpitações que ativam desvios, quedas e fracassos. Desapareço para que outras de mim componham camadas de imagens intensas que se manifestam em soluços, palavras ao pé do ouvido e rabiscos em folhas de jornal. Na ausência os pontilhados se reorganizam, os contornos trepidam e um sopro leve gera novos pensamentos que estão ora aí, ora aqui.

Negocio com o espaço,

flutuo,

aprendo sobre flutuações,

deixo o corpo cair levemente entre estruturas macias e caixas de papelão.

Envolvo-me em tecidos finos e observo o traçado da costura.

Atravesso as dobras, lugares sem avesso. 


\section{A descoberta}

Desenho pontos difusos que se espalham e avançam por paisagens extensas. Descubro que o teatro é um espaço formado por linhas paralelas, círculos, pontilhados oblíquos, formações instáveis, horizontais e caóticas que interligam pontos escorregadios como desenhos em papel de arroz. É nesse lugar que eu vivo experiências espaciais intensas. É no teatro que eu aprendo a desenhar.

No intervalo entre atos, o silêncio faz oscilar temperaturas, colorações e uma respiração profunda na qual ouço ecos de movimentos entre os meus órgãos. A matéria se expõe de tal modo que pedaços de mim somem.

O chão é a superfície que negocia diretamente com o meu peso e é a partir desse encontro que meu corpo esboça as primeiras linhas de contato através das quais tentarei me esticar pela arquitetura bamba ao meu redor.

Crio suspensões para que a percepção se movimente com mais facilidade. Deparo-me com o susto de não estar sozinha, de compartilhar sensações e variações que modificam a altura da fala. Ouço ruídos cheios de imagens e trepidações que modificam o ar. Devoro aos poucos a redondeza enquanto me sento em uma cadeira no canto de uma sala qualquer.

Proponho-me estudar essa paisagem frágil.

As qualidades que se manifestam no espaço, nas relações entre moléculas, planetas e objetos, se manifestam também entre pessoas, corpos e arquiteturas. Tramas que evidenciam leis, comportamentos e dinâmicas, confrontam a existência humana com uma série de acontecimentos e manifestações nas quais princípios físicos, matemáticos e equações em aberto geram um emaranho complexo no qual estamos sujeitos a oscilações, desvios, quedas, flutuações e demais situações ambientais. Não ocupamos o centro do quadro e tão pouco nossas trajetórias são retilíneas, previsíveis e organizadas por pontos de fuga estáveis e duradouros. Fazemos parte um sistema dinâmico e instável e observar suas características é voltar a atenção para princípios que promovem encontros, dissoluções e o surgimento do novo.

Enquanto trabalhamos com bases e conceitos fixos nosso olhar pousa na forma, na adequação aos sistemas e aos métodos. Entretanto, é quando o sistema entra em colapso que surgem novas articulações e elipses que indicarão novas trajetórias e a possibilidade de construção de novos acessos e dinâmicas entre corpos, objetos, lugares, desenhos da cidade e disposições espaciais. 
Manifestações dinâmicas espaciais se manifestam também no indivíduo. Indivíduo este que já não é aquele encerrado em si, mas que assimila, imprime e cria marcas enquanto se move. A paisagem agora é intervalo dinâmico entre indivíduo e ambiente, o toque de um interfere no outro e vice-versa. Sou o lugar que reage em minha pele da mesma forma que altero as proporções das geometrias dos caminhos que percorro. Uma dinâmica que não começa em mim e nem no ambiente, mas que está na intersecção, no ponto de contato que aciona múltiplas possibilidades de existir e perceber o mundo.

A instabilidade dos eventos, a constatação da impermanência e dos fluxos migratórios que inventam e transformam o ambiente constantemente me levam a suspeitar de verdades, de pontos de vista rígidos, de valores absolutos e de dualidades que me colocam dentro ou fora, à direita ou à esquerda e em cima ou embaixo. As leis que se aplicam às flutuações e indeterminações espaciais dizem respeito às interações entre corpo e espaço e alargam a minha percepção para novas condições ambientais, para novos modos de conhecer e me relacionar com o mundo. Se vivo e constituo espaços enquanto penso, ensaio, escrevo e converso, há de se levar em consideração a mutabilidade dos processos. Crio possibilidades de acesso ao mundo, invento respostas aos contrastes que geram tensões e experimento novas partituras para diferentes momentos e situações no processo de existir.

Se a produção de conhecimento parece se manifestar nessa construção de vias através das quais acesso o mundo, é preciso considerar o material de que são feitos esses acessos. Faço a primeira inspeção e logo detecto a fragilidade. A matéria frágil e porosa do meu corpo se depara com instabilidades temporais, com movimentos que atualizam e modificam constantemente o jeito que meus olhos devoram e são devorados por coisas, pessoas e opiniões. Se há instabilidade no processo de existir, há de haver transformações no modo de pensar, de criar relações e produzir conhecimento. Se os pontos de apoio são móveis e se há flexibilidade, há de fazer parte do processo mudanças rápidas de direção, desvios, sopros momentâneos e a construção de pontes que criam caminhos improváveis. Há de se criar novos trajetos da porta de casa até o ponto de ônibus.

As dinâmicas espaciais que destacam aspectos das relações que construímos e que são criadas em diferentes contextos é tema recorrente da arte contemporânea. O modo como vejo, como o corpo percebe, como o pensamento se manifesta no espaço, como danço novas maneiras de compor paisagens são algumas das questões da produção em arte. Essas problemáticas fazem o campo das artes se expandir e tocar em outras áreas de conhecimento. Um cruzamento de informações, práticas e conceitos favorece a afirmação da arte como força motriz para a construção de projetos e propostas experimentais que não se comprometem com 
o óbvio, com o já conhecido e fixado em manuais ou discursos antiquados dissociados dos aspectos ambientais e históricos que vivemos.

Um corpo não se move no espaço porque ambos são instâncias processuais e agentes em um processo complexo de somatórias, sobreposições, reorganizações e desaparecimentos.

Escrever sobre espacialidades é observar deslocamentos do corpo e dos sentidos e entrar em contato com questões a partir das quais a arte surge como paisagem frágil composta por muitas camadas.

Pesquisar, sob uma perspectiva menos dicotômica e mais fenomenológica, implica a tentativa de acessar as mais diversas variações do processo. Implica confundir-se com o próprio material de pesquisa, experimentar fisicamente qualidades e situações propostas por apontamentos teóricos, implica inverter a ordem do processo, começar por lugares que desconheço, perceber as mãos tocando pensamentos e os olhos desenhando estruturas instáveis para o percurso dos pés. Pesquisar fenômenos e eventos é como deitar-se na grama quando chove forte ou sentir a neve que cai suave sobre a pele quando a temperatura do ar é negativa. É negociar com contrastes e contradições, é suspender atributos e atividades cotidianas em nome de uma viagem que alastra os sentidos, que expande e contém o olhar. $\mathrm{O}$ rigor acadêmico e as imagens aleatórias que cruzam e ativam o pensamento.

\section{O olhar ambulante}

O primeiro desafio aqui é diluir o ponto de observação fixo e constante. Sugiro, para isso, um olhar ambulante que aciona movimentos, que liga pontos, rastros, esboços de imagens e pensamentos. Sou primeira e terceira pessoa de um processo que não me larga e que acontece enquanto caminho por ruas aleatórias, enquanto descubro lugares escondido em mapas que rabisco, enquanto aprendo sobre novas espécies, sobre as formações temporárias que se escondem por detrás da noção da existência ou sobre a distância entre planetas e estrelas que já não existem mais. Ideias, cidades, conversas, filmes, exposições, fotografias, pinturas, textos, leituras e olhares para o vazio fazem parte de um espaço complexo que me movimenta enquanto pesquiso. Estímulos e materialidades que alteram a minha percepção sobre o mundo.

Diluo-me, por alguns instantes, ao material e à matéria que me proponho estudar como modo de observar qualidades que só se manifestam em espasmos passageiros que alteram o corpo. Preciso entender a mudança a partir de faculdades que liberam o meu pensamento, que 
permitem a compreensão a partir de contornos e linhas que desenham a pele.

A fragilidade e a porosidade das estruturas alertam os sentidos para a passagem do tempo, para a impossibilidade da reprodução de formas e texturas sem que a percepção oscile e apresente novas ressonâncias.

Crio então caminhos provisórios, aproximo episódios e destaco situações que me fazem refletir sobre a continuidade dos lugares e o alargamento de conceitos. Observar sob diferentes perspectivas é incentivar a respiração, é fazer circular ideias e gerar espaço para o novo. Teatro, dança, artes visuais, por exemplo, são lugares que atravessam os limites das imagens e noções que se imprimem e se vinculam ao que passamos a entender como categorias, campos ou áreas das artes.

\section{A escrita}

Antes de me sentar para escrever essa tese precisei mudar tudo de lugar. Mesa, cama, cadeiras, casa, cidade e país. Mudar as coisas de lugar para que os objetos, as pessoas e as falas voltassem a agir sobre mim. Enquanto os lugares me movem, meus pontos de vista de alteram. Sobrevôo, flutuo entre pontos, me equilibro em linhas frágeis para encontrar novas perspectivas. A inversão das frases, o sentido da leitura, a direção dos pensamentos. Uma constelação de coisas em constante mudança e deslocamento.

Quando me coloco a mudar as coisas de lugar já intuo o que estar por vir. Ventanias que geram pensamentos desertos, lugares ainda solitários em mim.

Um pensamento é matéria tão vasta que não cabe em um conceito, não consegue se fixar ou se encerrar nele. Os conceitos me auxiliam, são os primeiros traços no mapeamento de uma viagem incerta e insegura na qual a imersão do corpo e as aderências das paisagens são capazes de produzir pontos de vista cambiantes nos quais percepções sensoriais, conceituais, sinestésicas, ósseas e atmosféricas se cruzam.

Entre considerações teóricas e práticas e entre conceitos e pensamentos acontece uma explosão. O momento em que a tela bidimensional se manifesta em complexas estruturas tridimensionais. Uma terceira dimensão que se desdobra em tantas outras mais que os desenhos se multiplicam em vetores indecifráveis.

A escrita deste trabalho está associada aos saltos e sustos que estremecem o meu olhar. E é sob o ponto de vista de alguém que formula pensamentos em salas de ensaio, que atua também na prática, que se coloca diante do outro em ambientes físicos e temporários, que 
abordo as problemáticas deste estudo.

Parto do pressuposto de que os pensamentos acontecem no corpo e que se reinventam em situações de saltos, rodopios, trepidações e mergulhos por texturas e intensidades desconhecidas e inicio essa pesquisa a partir de imersões e tateios físicos que acionaram em mim perspectivas e ângulos desconhecidos. Meu corpo assopra superfícies, volumes e frestas.

Writing is a corporal activity. We work ideias through our bodies; we write through our bodies, hoping to get into the bodies of our readers. ( p.76. Elspeth Probyn. Writing Shame em The Affect Theory Reader)

\section{O início}

Quando iniciei meus estudos em artes cênicas, meu objetivo era bastante claro: atuar. Sempre tive interesse pelo diálogo entre corpos, textos, palavras, objetos e pela construção de lugares e relações espaciais que produzem novos pensamentos. É na interação entre elementos, respirações e estruturas que se manifestam por alguns instantes e depois somem que eu experimento situações e crio perguntas para as equações que tento resolver enquanto atuo. Dançar, girar rapidamente, apagar conceitos e olhar o mundo de ponta a cabeça.

Entretanto o confronto com o espectador passou a ser uma constate. Tantos olhos, tantos corpos que ocupavam temporal e espacialmente o mesmo lugar que eu. E só eu atuava? E por que motivo eu deveria ignorar essa presença vigorosa que compartilhava o espaço comigo? Convenções se empenharam em separar lugares, em separar funções e em separar também práticas e pensamentos. Entretanto, o isolamento na cena passou a me sufocar. Eu queria me desdobrar em tantas, eu queria que meus olhos circulassem sem rumo e que minhas mãos fossem como tentáculos que tocam o mundo delicadamente. Eu queria multiplicar meus sentidos, dar um passo atrás, abrir a boca e emitir vozes de tempos passados e futuros. Eu queria o encontro com esses corpos que dividiam e construíam o espaço comigo.

E foi num susto que meu olho viu o olho que me observava. Desequilibrei. O espaço girou, uma vertigem intensa e desconhecida me jogou para fora da sala. Saí para estudar, para investigar essa intersecção, esse instante de encontro no qual espaços são produzidos. Fui dançar, estudar artes visuais, circo, trabalhei em ateliês de arte, em museus, dei aulas e voltei aos poucos e com cuidado ao lugar de partida. Entrei em uma sala de ensaio em silêncio, sozinha, desenhei esboços de movimentos, sussurrei algumas palavras e aos poucos tomei coragem para experimentar novamente o encontro. Obra e espectador, ator e público, corpos, 
materialidades e sensações que habitam lugares provisórios. Arquiteturas que se desenham a cada apresentação, cenas e estruturas vazadas por onde transitam gestos, vozes e silêncios.

E é nesta observação sensorial e aderente da prática teatral que eu localizo esse estudo. Passou-me a interessar o teatro como a possibilidade do encontro de ideias, pessoas, sensações e a experiência de um lugar onde a profusão de pensamentos acontecem entre práticas e teorias. Quis entender melhor esse imenso lugar no qual o teatro é localizado: a arte. E quanto mais eu estudava sobre dança ou artes visuais, mais eu me aproximava do teatro. Um movimento complexo e contraditório que me afastava e me aproximava do meu ponto de origem. Movimentos em múltiplos sentidos que me conduzem à investigação das problemáticas que apresento neste estudo.

A observação do fenômeno teatral, os pensamentos experimentados em rotações e deslocamentos do corpo, a percepção como ato dos sentidos e o lugar de encontro entre práticas e teorias. Observo agora a atuação sob uma perspectiva espacial extensa, como ocupação e produção de espaços, como possibilidade de estender-se para além da pele e dos músculos.

Na relação com o entorno e com o espectador a matéria em movimento e os impactos físicos que geram pensamentos espaciais irregulares e imprevisíveis passou a ser um dos meus temas de interesse. Os emaranhados espaciais que se misturam à percepção, a presença física e sensorial do espectador.

\section{A tese}

Sento-me para escrever sobre assuntos e pensamentos que estão agora amontoados em pilhas de anotações. Cadernos inteiros escritos, muitos rascunhos, linhas soltas em folhas brancas de papel, rabiscos em notas de supermercado, desenhos em programas de peças e em bulas de remédio, inúmeros arquivos de computador, escritas em múltiplas direções, pensamentos que fazem a curva, correm as folhas do caderno e percorrem cantos estreitos quando as linhas se acabam. Um overdose de informações em diferentes línguas. Frases em diferentes direções e sentidos.

Leio os livros mais incríveis sobre as mais complexas teorias e lamento não ter feito faculdade de filosofia. Ao mesmo tempo quero transformar tudo isso em grito, sopros e gestos sobre o mundo e sobre o humano. As notícias dos jornais e revistas cruzam as leituras de conceitos que preciso estudar e abrem brechas em meu pensamento sobre as relações entre 
prática e teoria. Faço pausas para observar minha respiração. Queria ser filósofa, mas o mundo me empurra de tal modo que eu escapo das palavras. Quero correr, transbordar lágrimas e sussurrar dores que persistem. Mergulho em ideias, mapeio abstrações para aprender a caminhar e a tocar lugares desconhecidos. Leio sobre teorias complexas para aprender a apenas olhar nos olhos e a me deslocar suavemente entre as estações.

Avisto o teatro sob o ponto de vista da pintura, da escultura, da dança. Cruzo lugares que me pareciam separados. Assisto aulas sobre história, filosofia, física e isso me parece fundamental para a construção de pensamentos sobre o teatro, sobre a produção em arte e sobre a construção de relações com o mundo.

Justamente quando arrumei a mesa e organizei os papéis para observar os pensamentos e começar a escrever sobre a complexidade do processo de fazer e não fazer parte, de pesquisar e ser também material de pesquisa, alguém publicava uma pequena nota na internet. Há exatos quinze minutos atrás li a seguinte publicação: "Durante um festival anual de artes na Inglaterra, o Breton Festival, o coreógrafo William Forsythe inovou e surpreendeu ao criar a 'Nowhere and Everywhere', uma instalação onde os visitantes dançam involuntariamente."8

“Os visitantes dançam”. Essa frase gerou, subitamente, uma visão panorâmica do terreno desta pesquisa. Dançar sem ter o intuito de dançar é perceber a dança como um fenômeno físico e ambiental que não se associa diretamente aos padrões e clichês que pontuam e afirmam o que é dança. Um jogo, a instalação de uma situação e vínculos entre corpo e espaço são ativados. Quando espectador, visitante, dançante, artista e pesquisador se cruzam a passividade observadora é olho que vê e é visto.

Do ponto de vista de fora que é o dentro do lado que se move, artista é pesquisador que é espectador dançante em pleno ato e pensamento. O vôo que atravessa territórios de um único lugar.

$\mathrm{Eu}$, a geografia. A grafia da terra. $\mathrm{O}$ desenho por onde corre o rio. $\mathrm{O}$ declive da montanha e o desejo incontrolável de separar para juntar. A pura contradição.

O rigor acadêmico das notas de roda pé e as citações menos coerentes. Um som baixinho do outro lado da janela e o chá esfriando na xícara ao meu lado.

Mesa pronta. Livros organizados na prateleira e dois ou três cadernos abertos ao lado do computador. Marcadores de livro, frases grifadas em cores fortes e folhas dobradas.

Passo a observar meu corpo, os pés e apoios de cadeiras e sofás, as estruturas geométricas, os volumes de ar, a matéria densa que empurra a minha pele e a pressão que

\footnotetext{
${ }^{8}$ Disponível no link: https://br.noticias.yahoo.com/instalação-de-arte-transforma-visitantes-em-dançarinos130527082.html. Acesso em 20.05.2014
} 
desenhou as minhas digitais. Caminho com cuidado e percebo que as formas ao meu redor se aderem a minha respiração. Pele, ossos, madeira e um amontoado de pessoas e cidades. Cores e texturas que provo com a ponta dos dedos. Olho para cima, um degrau acima dos olhos, e a paisagem me engole. Sou ponto que se soma às linhas e aos pontilhados que contornam as coisas do mundo. Sou a eminente dissolução de mim mesma.

Sob essa perspectiva que gruda, que junta registros e lugares improváveis e depois espalha e dispersa tudo para que novas espacialidades ocorram, a percepção coincide com a manifestação de suspensões, giros, paradas, e a variação do olhar. No momento em que sou descolada de um referencial e percorro variações, arquiteturas, paisagens, campos dispersos e ambientes indeterminados. Aquilo que faz girar pensamentos, órgãos e músculos acontece na interação dinâmica de um conjunto de forças. Perceber coincide com o ato de suspender, de fazer oscilar referenciais, pausar e desvincular de um único ponto de observação. $\mathrm{Na}$ movimentação da percepção acontecem demoradas ou ligeiras suspensões do olhar acostumado, os sentidos desviam dos percursos comuns, o ritmo e os passos variam e novas ruelas são descobertas. Um lugar frágil se instala e suspende o tempo acelerado, ou as temporalidades fixadas em determinações. Paisagens frágeis e temporárias se sobrepõem às demarcações de terrenos e aos nomes das ruas.

A vertigem gerada pela oscilação dos sentidos faz o corpo gerar novos ângulos e medidas. O espaço vibra, as linhas se alteram e novas relações são geradas.

Uma pesquisa desenhada sob a perspectiva do surgimento e do apagamento de paisagens frágeis coincide com a sua localização em um terreno movediço que espalha, cruza e mistura referenciais práticos e teóricos. Aquele que escreve perfura a imagem, as palavras, a organização dos textos para tocar e desmontar linhas e tonalidades, para experimentar a cor e o peso na interação com a superfície da pele. Aquele que escreve desenha pensamentos que apertam o estômago, que transbordam pelas pontas dos dedos e oscilam entre incursões físicas, materiais e subjetivas por espaços quebradiços.

\section{A sala de ensaio}

Vou para a sala de ensaio e começo a escrever.

Comecei a escrever este texto em uma sala de ensaio. Escrevi percursos e tateei registros para acessar pensamentos que encostavam a ponta dos meus pés. Foi em uma sala de ensaio que esbocei as primeiras linhas deste trabalho. O tempo das negociações com o vazio, 
com a escuta, com a investigação de relações que assopram o ar e fazem coisas inanimadas se mexerem. O tempo e o espaço onde aprendo a desenhar, a gerar pensamentos que se misturam à brisa fria e densa na qual eu respiro melhor.

Para observar as variações que tocam os sentidos e mobilizam transformações entre corpo e espaço, entre obra e público, entre o corpo do artistas e os corpos dos espectadores, entrei sozinha em uma sala de ensaio e experimentei respirações entre prática e teoria, deslizei de um canto ao outro da sala observando os mecanismos e as interações que favorecem a construção de espacialidades.

Rabisco mapas, experimento sensações, caminho em silêncio e desenho meus primeiros pensamentos em letras que se imprimem no chão de uma sala de ensaio.

Experimento em meu corpo e em minha relações com o entorno em diferentes perspectivas, o vôo de um canto para o outro, a assimilação do entorno e tateio os efeitos do ar em minha pele.

\section{Pontilhados}

Eu sozinha no centro de uma sala.

Um espaço delimitado por paredes, um piso de madeira, três janelas e uma porta. Descolo-me para o canto direito. Em seguida, corro até o canto onde está uma das janelas. Deito-me. A respiração ofegante, os calcanhares tocando o chão. Observo o teto. Minhas costas no chão. Meus ombros me impulsionam para cima. Repito movimentos que meu corpo já conhece. Levando e caminho lentamente até a porta.

Abro e fecho a porta. Caminho de costas. Passos longos e lentos. Toco a janela. Meus ombros de vidro ficam parados enquanto algum barulho atravessa a pequena fresta aberta. Cortam a grama do lado de fora. O lado que entrou para a sala. Deito querendo ouvir a grama.

Silêncio.

Observo. Analiso a parede pesada. Levanto e corro para a porta, volto de costas e percorro novamente todo o trajeto. Acelero o passo. Encosto, aproximo, afasto, deito e levanto. A janela, o vidro e a grama.

As palavras janela, grama e vidro estão agora sozinhas. Quero escrever um conto inteiro com a palavra grama.

Caminho até a janela da esquerda, apoio as minhas mãos no vidro e toco no jardim ao lado. Sob uma perspectiva aérea não estou ao lado, mas dentro. Deito-me no jardim e escuto 
novamente a grama.

Um rodopio que me coloca no centro e na periferia. Dentro e fora, longe e perto.

Algumas convenções acalmam os ânimos e me proporcionam uma leve sensação de controle e bem estar.

Observo, analiso, descrevo, separo. Caminho procurando linhas retas ou sinuosas para os próximos passos. Busco esquemas e simplificações para explicar o complexo e o contraditório.

Procuro definir aquele que pesquisa. Apago tudo e escrevo novamente. Escrevo as trajetórias do meu corpo. Inscrevo-me nos saltos, nas pausas e descubro o paladar. A ação de absorver, ingerir, deglutir e processar. Já sou ação.

A pesquisa e a espectadora que atravessou o quadro. $\mathrm{O}$ espectador é agora tinta misturada à tela, impressão e memória na parede que prendia o quadro. Pontilhados contínuos que misturam lugares e funções.

A pesquisadora observa enquanto a espectadora escreve. As folhas amassadas ao lado do computador e os trilhos que ligam as estações. Fios se cruzam sobre uma passarela verde que termina na partida do trem. Sentar para escrever quando se deseja dançar. Dançar e procurar blocos de anotações para aquilo que é desenho em folha de papel.

Eu que daqui desse texto desejo dançar. Eu que entre uma e outra página em branco abro as janela, observo as árvores silenciosas e compridas e deixo o vento frio entrar até que a pele se arrepie. Respiro, saio, corro pela floresta ao lado de casa e busco movimentos que diminuam a distancia entre algum eu e o mundo. A dissolução da pele.

Amasso as folhas de um texto que escrevi. Deito-me no chão, percebo o peso do corpo, a superfície gelada e respiro. Desamasso algumas palavras e sussurro, quase em silêncio, uma das frases que mais gosto de um dos trabalhos do Leonilson "com um oceano inteiro para nadar". Cruzo um caminho de mão única. Debaixo da água não estou separada e é de lá, com os olhos quase fechados, que percebo o meu corpo leve procurando as bordas. A incessante necessidade do ponto de observação. O incontrolável desejo de observar. O corpo mergulhado e os olhos descrevendo as ondas. Pedras paleolíticas e uma infinidade de memórias que tocam o mar. 


\section{PasSagens}

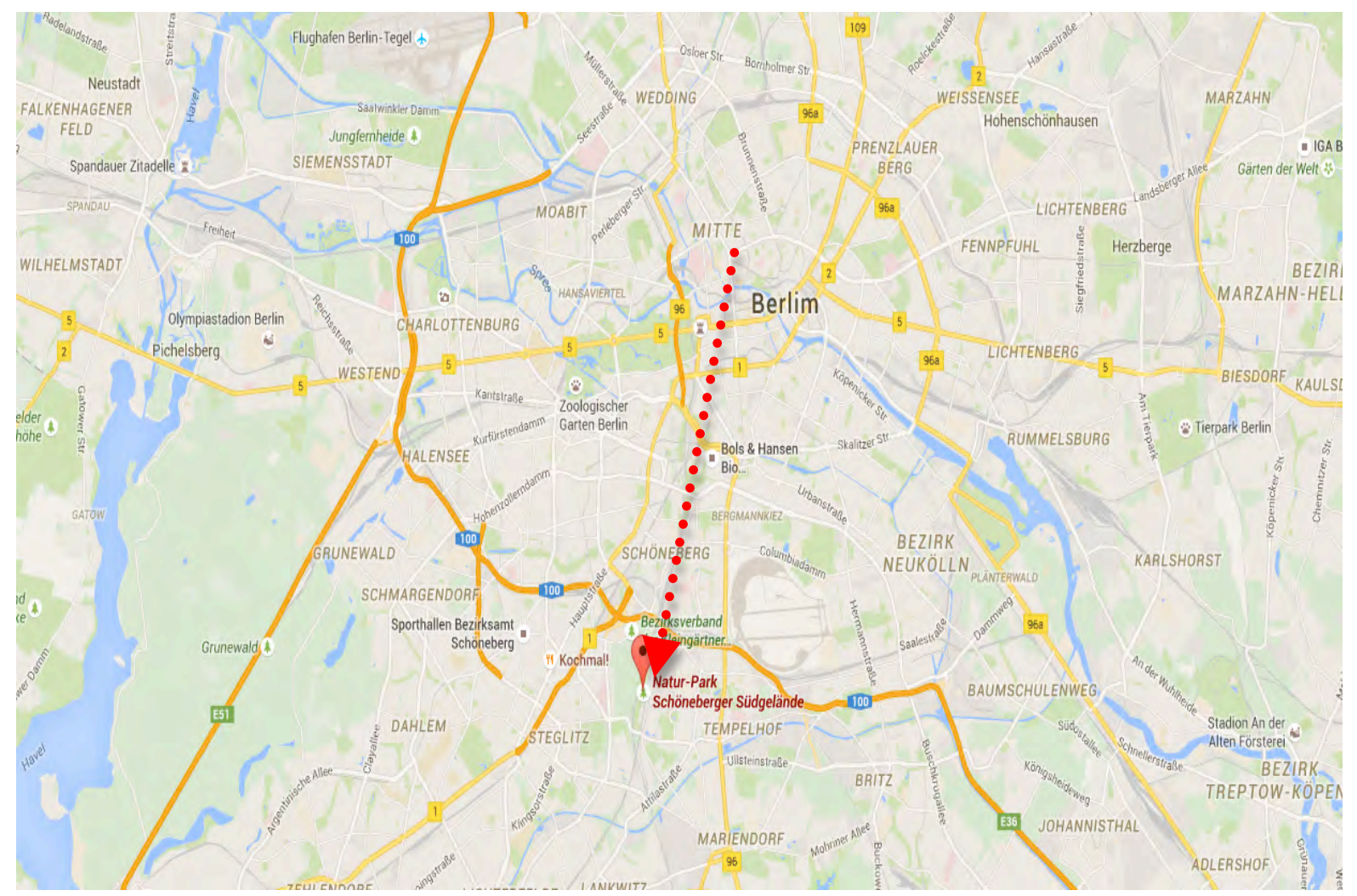




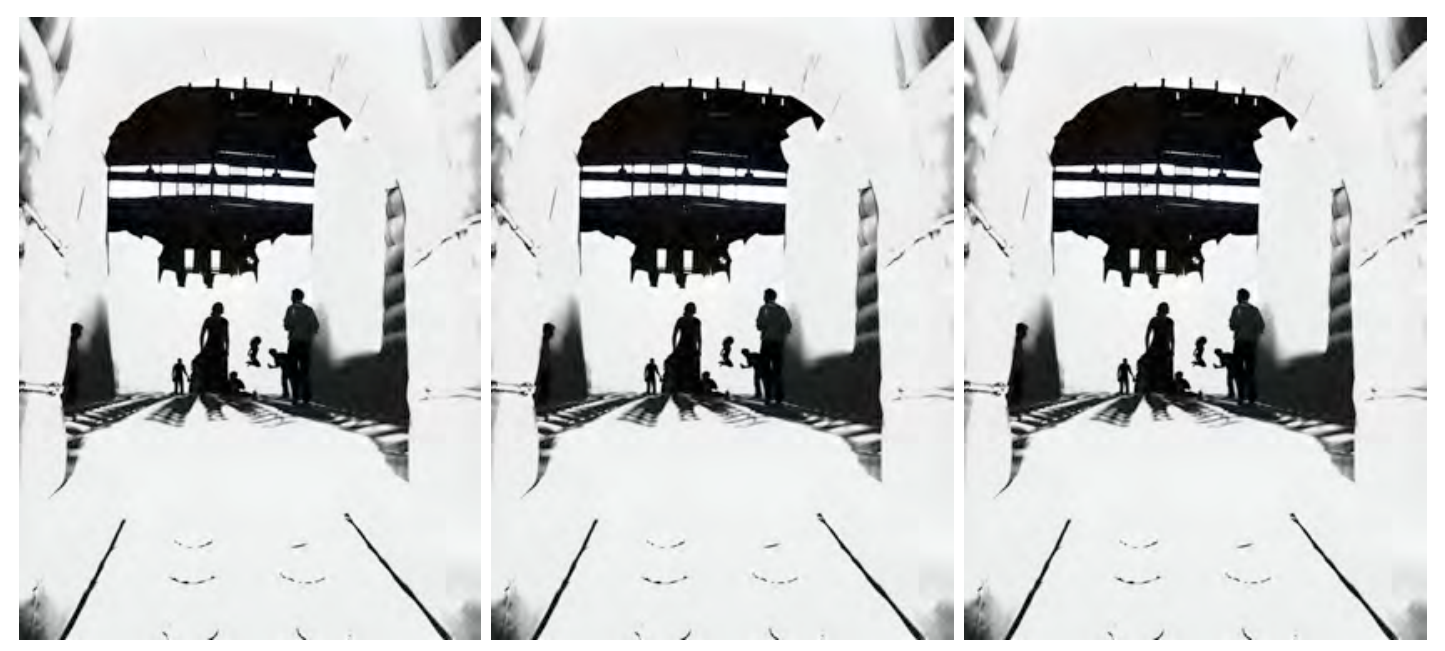

Berlim, julho de 2013.

O primeiro contato com um dos trabalhos de William Forsythe aconteceu em Berlim, em julho de 2013, no parque Natur-Park Schöneberger Südgelände. O trabalho White Bouncy Castle, um enorme castelo branco inflável no qual o espectador é convidado a entrar, foi instalado dentro de um grande galpão antigo no meio de um parque em Berlim durante o festival Berliner Festspiel. O caminho até a instalação de Forsythe prevê um deslocamento do centro, dos prédios, do trânsito de bicicletas para uma região mais verde e silenciosa da cidade. O parque começa logo ao lado da estação de metrô. Pelos anúncios ao logo do caminho, inúmeras peças e concertos são apresentados por ali. A areia solta, árvores, trilhas, bancos e fragmentos de construções compõem a paisagem de acesso ao galpão onde o White Bouncy Castle se encontra.

Já na porta do galpão, avisto o castelo. Um castelo dentro de um galpão. À primeira vista, não há qualquer espanto, admiração ou surpresa. Um espaço dentro de um espaço e ambos localizados no contexto do parque. Da porta é como se eu pudesse ver dois quadros pendurados na paisagem do parque. O galpão sendo representando por um galpão e um castelo por um castelo. Os limites bem definidos e os lugares separados.

Logo na entrada, algumas indicações: tirar os sapatos e guardar as bolsas e mochilas.

Entro, tiro os sapatos. Descalça no galpão, caminho até o guarda-volumes. Logo escuto uma música e percebo os tapetes que indicam a entrada do castelo. Antes da entrada, uma ponte. E antes da ponte a sensação de ser minúscula diante da instalação. A ponte inflável que conduz até a porta. $\mathrm{O}$ primeiro passo e o desequilíbrio. $\mathrm{O}$ ar que sustenta o castelo faz oscilar o meu passo e o peso do meu corpo. Minhas pernas ficam menores e quando tento olhar para 
cima alguém salta ao meu lado e quase caio. Outras pessoas estão dentro do castelo e se movem de um lado para o outro. Umas, cambaleando, entram e logo se aproximam do chão, outras, com movimentos rápidos, saltam longe e logo se equilibram. $\mathrm{O}$ menos óbvio regula o espaço. Quero manter o eixo, piso firme no chão e caio. Levanto-me. Procuro modos de me relacionar com esse material enorme, cheio de ar e de pessoas. Um salto pequeno e tímido. $\mathrm{O}$ peso descolado do chão e logo encontro uma zona mais estável. No ar. Salto mais alto, e quanto mais alto o salto, mais estável o movimento. As paredes me jogam para dentro e o centro me impulsiona para as paredes. Experimento modos de permanecer no centro e modos de me deslocar para os cantos. Deito e levanto. Aos poucos descubro novas maneiras de organizar e acomodar o meu corpo nesse espaço. O corpo experimenta novas disposições, novas relações de peso e altura, o chão mais próximo, o contato com o solo, o salto distante e o corpo infinitamente mais leve. Cair, levantar, desprender-se. E entre um salto e outro percebo o lado de fora do castelo. Um lado de fora que é agora também lado de dentro. E de lá vem a música que ouvi logo que entrei no galpão. E o galpão aparece como um vão livre, um território de passagem. O lugar plantado no parque ou um parque plantado ao seu redor. Aquilo que da posição de dois passos atrás da porta principal do galpão era visão de lugar fechado dentro de lugar fechado é agora, da altura de um salto no interior do castelo, justaposição, cruzamento e desenho de uma arquitetura móvel que me joga para fora e para dentro. Habito o desenho.

Há nesse trabalho o traço forte do lugar projetado como a figura de um castelo. Há a forma daquilo que conhecemos como castelo. O trabalho, como imagem, está em um campo de representação que estimula leituras um tanto quanto previsíveis. O castelo que é um castelo. As formas e as proporções, simulam, mesmo que em uma escala bastante reduzida, o que poderia ser a experiência de um castelo. Entretanto, o primeiro contato físico com o trabalho abre portas para sensações e relações espaciais pouco prováveis no contexto de um castelo. As paredes de pedra são agora grandes estruturas de ar. O que há de rígido e estável na construção de um castelo, na instalação de Forsythe é volátil, aéreo, instável e oscilante. O esquema da representação é desmontado pela ação que o ar exerce em meu corpo. Quando estou na instalação os limites da representação se desprendem da imagem e agem diretamente sobre os meus movimentos. Agindo e reagindo a forma do castelo se desfaz. Toda a atenção se volta para o percurso físico e para a escuta desse espaço que construo com os corpos que se deslocam comigo.

O espectador habita e desmonta o lugar da representação. Trajetos e percursos criam novas linhas e pontos de contato entre castelo, galpão e parque. A percepção se move. 
Depois de saltos, quedas, variações de peso e sensações, caminho em direção a saída da instalação. Piso no chão firme. O corpo ainda querendo subir. Vetores me jogando para o alto e o peso de cada passo. Sigo os tapetes que me levam até o guarda-volumes. Pego a minha mochila e me sento no chão. Quero observar um pouco mais as sensações. O leve e o pesado. Cansada, sinto ainda as pernas procurando o ar. O corpo encontrando eixos e se organizando a cada salto. O corpo livre. O que aconteceu? Desprendi-me e o corpo se lançou longe.

Entendi o que procurava nos trabalhos de Forsythe. Quero dançar. E o castelo provocou essa dança inesperada. Uma dança que não segue passos, mas que é a construção de uma coreografia percorrida e gerada pelo meu corpo. Um objeto coreográfico. Um objeto gritante que puxa e empurra o meu corpo.

Nesse lugar, objeto e observador se transformam em experimentação e construção de percepções e memórias. Sem regulamentações, a arte atua em um campo mais livre e destituído de regras e padrões constituídos. Experimenta-se o experimental. Na década de 60, Helio Oiticica, no texto Experimentar o Experimental ${ }^{9}$, diz que o exercício experimental da liberdade evocado por Mário Pedrosa não consiste na "criação de obras" mas na iniciativa de assumir o experimental. Assumir o movimento, o percurso, a construção de diálogos e potencialidades. $\mathrm{O}$ experimental como zona de interação e disparador de ações que agem nos limites entre matéria e representação, por exemplo.

Em White Bouncy Castel o objeto castelo se apresenta como esse lugar previamente desenhado, porém aberto e à espera de movimentos que produzirão a própria matéria que constitui o trabalho. Esse abrigo, ou lugar de passagem, situado nos limites entre matéria e representação assume o risco do experimental enquanto múltiplas danças se instalam e corpos experimentam e descobrem percursos.

Matéria é um conjunto de imagens diretamente vinculadas à percepção, de acordo com o filósofo francês Henri Bergson (1859-1841). Tais imagens transitam em um intervalo entre a "coisa" e a "representação". Matéria não é aquilo que se encerra na ideia que temos de um objeto, mas a construção de relações que coincidem com o surgimento de imagens. Matéria e percepção aparecem como fenômenos de um único processo. De acordo com Bergson (2010), o primeiro contato com a matéria, acontece mediante a presença e a interação do corpo em um processo complexo de afecção e construção de imagens. Memórias, registros e sensações se relacionam com a "coisa" e produzem matéria. Quando experimento o trabalho White Bouncy

\footnotetext{
${ }^{9}$ Texto disponível no site do Itaú Cultural: http://www.itaucultural.org.br/aplicexternas/enciclopedia/ho/index.cfm?fuseaction=documentos\&cod=362\& tipo =2. Acesso: 3.11 .2013
} 
Castel, atravesso a área de representação do castelo, atravesso o desenho que vinculo à ideia da coisa castelo e construo matéria no momento em que meu corpo girando e saltando de um lado para o outro acessa e produz imagens. O que havia como ideia de castelo, como área de representação, é agora matéria que meu corpo percorreu e gerou. O castelo é agora esse lugar em expansão e conjunto de imagens construídas durante o percurso. A representação, nesse contexto, pode ser entendida como um conhecimento parcial de uma determinada imagem ou objeto.

Sob esse ponto de vista, conhecer coincide com interagir e a interação diz respeito ao conceito de movimento real também abordado por Bergson. Movimento real é uma qualidade ou sensação em vibração e em desenvolvimento em um número incalculável de eventos. Esse movimento complexo e que acontece em várias direções não é aquele estudado pela física clássica ou pela mecânica, que prevê a sistematização de símbolos ou abstrações, mas sim um deslocamento que acontece à medida que as interferências e as sensações acontecem. $\mathrm{O}$ movimento real coincide com a conversão da matéria em uma rede de estímulos, "todos ligados numa continuidade ininterrupta, todos solidários entre si, e que se propagam em todos os sentidos como tremores." (Bergson, 2010: 245). E ainda sobre o movimento real: "Vale dizer que toco a realidade do movimento quando ele me aparece, interiormente a mim, como uma mudança de estado ou de qualidade." (Bergson, 2010: 229-230).

Deste modo, a ideia de um mundo exterior a nós é superada. $\mathrm{O}$ mundo existe à medida que eu me relaciono com ele, à medida que me movimento, escuto, sou empurrada, toco e danço. Neste processo, a continuidade aparece em intervalos e movimentos que interligam todas as coisas e a fragmentação a qual recorremos para explicar os eventos é um procedimento artificial assim problematizado por Bergson (1999):

\footnotetext{
De que modo fragmentamos a continuidade primitivamente percebida da extensão material em tantos corpos, cada um dos quais com sua substância e individualidade? Certamente essa continuidade muda de aspecto, de um momento a outro; mas por que não constatamos pura e simplesmente que o conjunto mudou, como se houvéssemos girado um caleidoscópio? Por que buscamos enfim, na mobilidade do conjunto, pistas deixadas por corpos em movimento? Uma continuidade movente nos é dada, em que tudo muda e permanece ao mesmo tempo: como se explica que dissociemos esses dois termos, permanência e mudança, para representar a permanência por corpos e a mudança por movimentos homogêneos no espaço? (BERGSON, 1999:231)
}

Neste trabalho de Forsythe, o plano da representação em que os elementos agem de modo fragmentado e descontínuo cede lugar a um ambiente extenso onde dança e percepção aparecem como deslocamento de memórias e produção de matéria. A instalação de Forsythe, 
em diálogo com princípios e conceitos abordados por Bergson, é campo de experimento, de aceleração e desaceleração do tempo, é abrigo de sensações e estrutura que lança o corpo a uma dança susceptível às leis do acaso e da sincronicidade.

Nesta experiência, o meu corpo provou prolongamentos, extensões e fez curvas. E foi em um instante de suspensão provocado pelo ação do ar em meus sentidos que experimentei forças e qualidades que mobilizariam essa pesquisa. A perda do centro, a oscilação dos eixos de apoio e a mudança radical dos pontos de observação produziram orientações e problemáticas que foram chegando aos poucos. Foi preciso dar tempo ao tempo e deixar que o corpo se habituasse à vertigem e o pensamento aleatório, ao pensamento que acontece na interação entre estímulos e fatores ambientais. 


\section{linhaS}
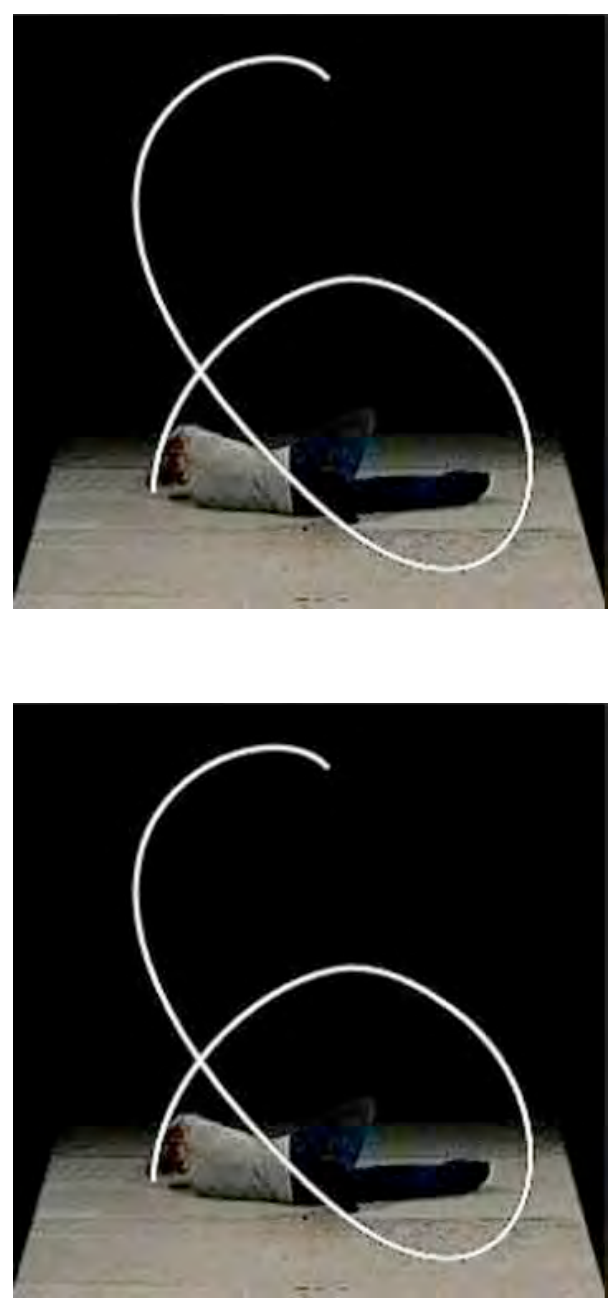

William Forsythe ${ }^{10}$ : Estou inclinado a acreditar que porque somos corpos e possuir mecanismos de percepção nós também possuímos tempo. Eu suspeito que a nossa capacidade de construir tempo baseia-se na maneira pela qual o corpo integra suas percepções e aplica a ação necessária para gerar essas percepções. A característica que eu mais associaria com o tempo corporal é a insustentabilidade. Nada no corpo pode ser mantido indefinidamente. Espaço sem qualidades. Por que não podemos imaginar isso? (FORSYTHE, 2008, tradução nossa ${ }^{11}$ )

${ }^{10}$ Entrevista disponível no catálogo produzido na ocasião da exposição William Forsythe, Suspense, de 2008. Páginas: 50 e 77.

${ }^{11}$ Texto original: "I am inclined to believe that because we are bodies and possess perceptive mechanisms we also have time. I suspect our ability to construct time is predicated on the manner in which the body integrates its 


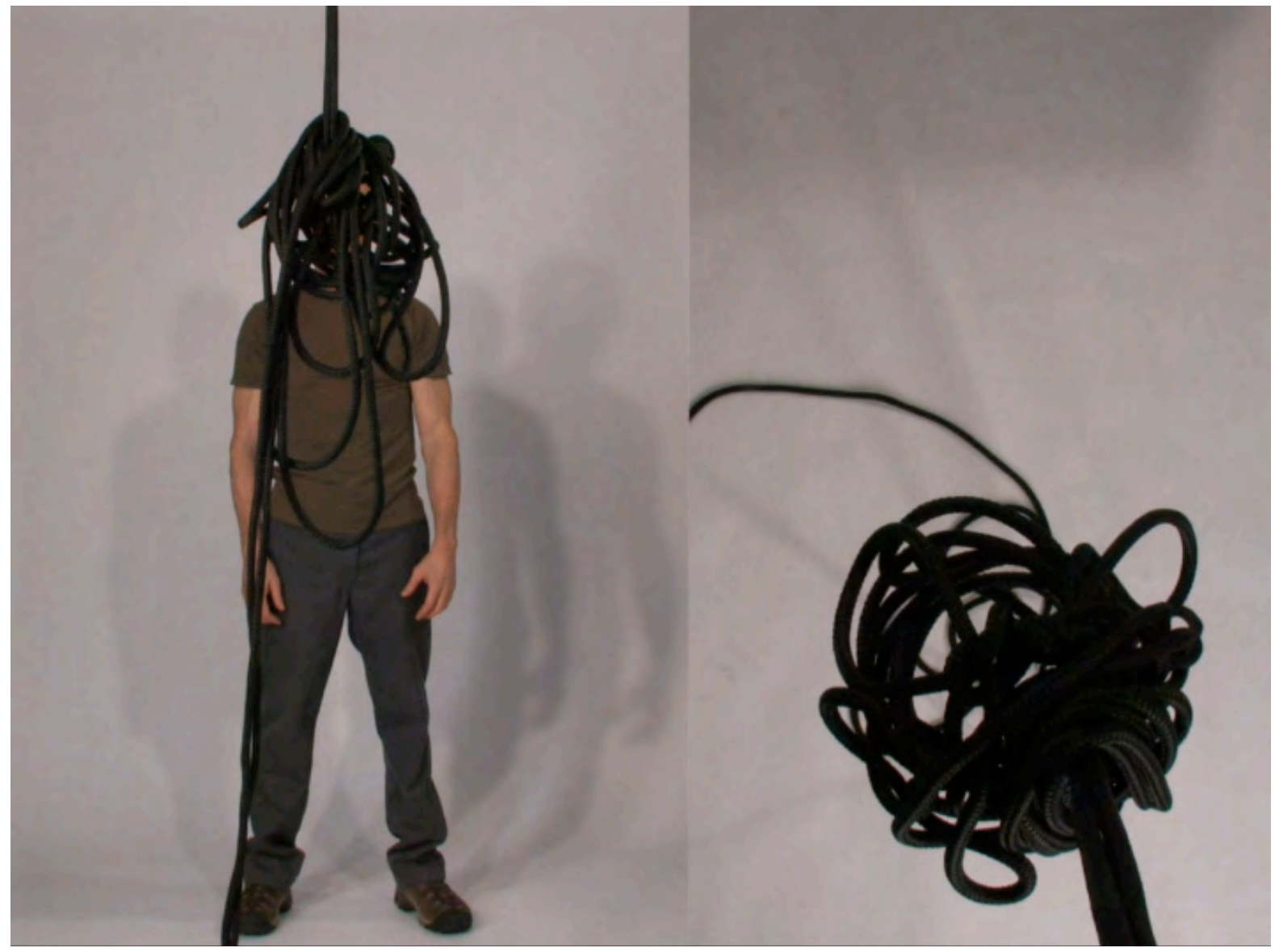

Suspense, 2008

\section{William Forsythe}

William Forsythe nasceu no dia 30 de dezembro de 1949, em Nova Iorque, e por 30 anos, trabalhou e viveu na Alemanha. O longo período na cidade alemã de Frankfurt misturou as línguas, os sotaques e os seus vínculos afetivos. Suas frases são palavras e pensamentos que se confundem entre o inglês e o alemão.

Em entrevista ${ }^{12}$, na ocasião da Bienal de dança de Veneza, William Forsythe se apresenta como artista que atua no campo da coreografia. Essa afirmação nos conduz a uma localização múltipla e descentralizada do seu trabalho, já que a noção de coreografia investigada por Forsythe não coincide com uma analogia ao universo organizado ou padronizado muitas vezes associado à prática da dança. Coreografar implica rastreamento, investigação espacial, dissoluções, alteração de eixos, ativação da percepção e deslocamentos

perceptions and upon the action necessary to generate these perceptions. The characteristic I would most associate with bodily time is the unsustainable. Nothing in the body can be sustained indefinitely. Space whitout qualities. Why can't we imagine it?"

${ }^{12}$ Entrevista disponível no link: https://www.youtube.com/watch?v=wb9QNghklPk. Acesso em maio de 2015. 
de matérias e memórias. A orientação de seus procedimentos e percursos coreográficos coincide com linhas que se cruzam, que aparecem e somem e que esboçam desenhos foscos e trepidantes que produzem espacialidades na relação do corpo com o entorno.

De acordo com Gerald Siegmund (2004), William Forsythe iniciou tarde sua educação formal em dança. Nascido em 1949, em Nova Iorque, quando jovem foi fascinado por Fred Astaire, filmes musicais e Rock'n'Roll. Forsythe revela, em entrevista ${ }^{13}$, sua intimidade com a música:

\begin{abstract}
P: Como foi a sua infância?
$\mathrm{R}$ : Eu cresci em uma família musical. Meu avô era um violinista de concerto. Ele foi uma criança prodígio; ele teve sua primeira estreia em Viena, quando tinha 12 anos. Ele me ensinou violino mas me explicou que eu não seria um grande violinista e disse que eu seria melhor como condutor. E eu fui aprender fagote e flauta. De modo que eu toquei três instrumentos e depois eu cantei num coro. Meu pai era pianista também, então que havia muita música clássica em casa. Ao mesmo tempo, eu tive uma criação normal americana das décadas de 50 e 60 , na qual tinha muito rock'n roll. Motown (Record) era muito importante e eventualmente também o funk. Então, eu era algo entre dois mundos, praticamente. E eu me sentia muito confortável. Em outras palavras, eu posso ouvir de funk a Bach. (FORSYTHE em entrevista: por Claire Lee, 2013, tradução nossa) ${ }^{14}$
\end{abstract}

A presença da música e de ambientes sonoros em suas composições reflete seu interesse e intimidade com a cultura musical americana. "O fator mais importante para mim era a cultura musical americana", disse Forsythe em uma entrevista à Rosalyn Sulcas ${ }^{15}$, e "eu estou feliz por ter aprendido balé só posteriormente - deste modo uma (linguagem) ${ }^{16}$ pode se infiltrar na outra."

De acordo com Siegmund (2004), o universo estreito e fechado do balé clássico, no qual as pessoas entram cedo e lá permanecem, Forsythe não conheceu.

\footnotetext{
13 Entrevista concedida na ocasião da estreia do trabalho Heterotopias na Coréia do Sul. Texto disponível no link: http://www.koreaherald.com/view.php?ud=20130410000930. "William Forsythe on Foucault's 'space of otherness."” Por: Claire Lee. Acesso em 23/04/15.

${ }^{14}$ Texto original: "Q: What was your childhood like? A: I grew up in a musical family. My grandfather was a concert violist. He was a child prodigy; he had his first premiere in Vienna when he was 12. He taught me violin but explained to me that I would not be a great violin player and said I would be a better conductor. And I went on to learn bassoon and flute. So I played three instruments and then I sang in a chorus. My father was a piano player also, so there was a lot of classical music at home. At the same time, I had a normal, American '50s, '60s upbringing, where I had a lot of rock ' $n$ ' roll. Motown was very important and funk eventually came in. So I was sort of between two worlds, pretty much. And I feel very comfortable. In other words, I can hear the funk in Bach."

${ }^{15}$ Texto original: "und ich bin froh darüber, Ballet erst hinterher gelernt zu haben, - auf diese Art konnte das andere in es hineinsickern". Citação disponível no livro "Denken in Bewegung", Gerald Siegmund, 2004:11

${ }^{16}$ Tradução aproximada.
} 
Sigmund (2004), comenta ainda que Forsythe aos dezessete anos foi para a Flórida, onde estou na Universidade de Jacksonville. Durante o seu período de formação em teatro e história da arte, participou de palestras e aulas em diferentes áreas. Por duas vezes foi considerado o melhor aluno do ano, entretanto nunca terminou nenhum curso. Uma de suas matérias favoritas era matemática, cujas abstrações e lógicas inspiram até hoje suas investigações e produções artísticas. Outros campos de conhecimento que despertam seu interesse são a física e a astrofísica. E é nesse cruzamento de áreas e estudos que exploram qualidades e formações espaciais que suas investigações se alicerçam.

Forsythe fez aulas de dança moderna e de balé, dançou e coreografou. Em 1969 ele deixou a Jacksonville e ganhou uma bolsa de estudos para o Joffrey Ballet School, em Nova Iorque, onde teve aulas com Jonathan Watts, Maggie Black e Finis Jhung. Ele dançou na companhia júnior Joffrey Ballet 2 e mais tarde na companhia principal.

Em uma apresentação do Balé de Stuttgart, como espetáculo convidado, em Nova Iorque, em 1973, John Cranko, diretor da companhia, convidou Forsythe para um trabalho com o seu grupo.

Em 1976, Forsythe teve a chance de apresentar a sua primeira coreografia, na NoverreGesellschaft ou Sociedade Noverre, uma matinê para jovens coreógrafos, em Stuttgart, na Alemanha. Urlicht, um dueto para ele e sua então esposa Eileen Brady, foi um sucesso e a neste ano ele foi nomeado como um dos três coreógrafos residentes do Balé de Stuttgart, onde trabalhou por quatro anos. A partir de 1980, Forsythe parte para uma carreira freeelance e trabalha com companhias em diferentes países e cidades.

No ano de 1983, William Forsythe cria Gänge, para o Balé de Frankfurt, e é nesta ocasião que ele é convidado para assumir a direção artística da Companhia. No ano de 1984, Forsythe assume, como coreógrafo, a direção do Balé de Frankfurt e inicia uma longa e transformadora parceria de vinte anos que implicará em importantes mudanças de perspectiva sobre a dança e sobre o balé, principalmente. Essa parceria transforma uma companhia regional de balé em um dos grupos de dança contemporânea mais conhecidos mundialmente.

Artifact é o primeiro trabalho de Forsythe, como diretor do Balé de Frankfurt, em 1984. Este trabalho, embora ainda pautado em referenciais clássicos do balé, explora possibilidades espaciais para o corpo a partir de procedimentos que enfatizam o peso, o ritmo e a formação de arranjos espaciais que aparecem como volumes complexos e dinâmicos que movimentam e rearticulam a área do palco. Desde então, suas investigações se intensificam e promovem o surgimento de novas lógicas e relações entre os padrões já conhecidos do balé clássico.

Produzido dois anos depois de Artifact, o trabalho Die Befragung des Robert Scott 
marca o início de uma fase investigativa mais radical na qual as ambiguidades e as impossibilidades colocadas pelos modelos clássicos do balé fornecem material para a criação de procedimentos técnicos e de improvisação que aparecerão na ideia de "Kinetic Isometries" (Isometrias cinéticas). Esses procedimentos criados por Forsythe e sua Companhia exploram modos de imaginar relações geométricas entre diferentes partes do corpo em movimento. $\mathrm{O}$ que fica claro neste período é que Forsythe assume o movimento como o seu principal material de investigação. Neste contexto, o "movimento seria pergunta ao invés de resposta", afirma Roslyn Sulcas (2011) ${ }^{17}$.

Sua atuação no Balé de Frankfurt é marcada por grandes realizações e também por crises que colocam em questão a manutenção do balé como forma padronizada e passível de reprodução por diferentes corpos e contextos.

Por questões e problemáticas internas, em 1999, o Balé de Frankfurt passa a apresentar a maior parte dos seus trabalhos no Bockenheimer Depot, em Frankfurt.

O trabalho Wear, que estreou em 2004, em Frankfurt, de acordo com Siegmund (2004), é pautado em questionamentos de Forsythe em relação aos referenciais do balé clássico. As crises e as expectativas em relação a continuidade do Balé de Frankfurt como uma companhia de balé que não se afastasse totalmente de referências e aspectos do balé clássico provocaram o interesse de Forsythe pela abordagem deste tema.

Gerald Siegmund (2004) faz uma descrição detalhada dos ambientes espaciais deste trabalho. O Bockenheimer Depot está mal iluminado e diferentes figuras transitam pelo espaço com roupas que interferem na qualidade e na amplitude de seus movimentos. No espaço, há um grande banner com a seguinte frase: "37 anos de futilidade" e três figuras presas a condições adversas. As roupas remetem à ideia de que estão em alguma região polar. Durante a performance os dançarinos se livram dessas roupas, ampliam seus movimentos e instalam assim um novo ambiente.

Dentro de um vasto repertório do Balé de Frankfurt, Wear foi apenas uma nota de rodapé, como comenta Sigmund (2004). Este foi o penúltimo trabalho da Companhia coreografado por Forsythe antes do fechamento do Balé de Frankfurt pelo estado, em 2003/2004. A frase “37 anos de futilidade”, de acordo com Siegmund (2011), faz uma alusão à atuação de Forsythe, desde o início de sua carreira como dançarino e coreógrafo na Jacksonville University, na Flórida, em 1967, e ao seu descontentamento em relação às

\footnotetext{
${ }^{17}$ No texto "Watching the Ballett Frankfurt, 1988-2009", no livro William Forsythe and the practice of choreography, org. Steven Spier, 2011. Texto original: "moviment could be question rather than answer", Roslyn Sulcas (2011).
} 
diversas tentativas de recuperação do Balé de Frankfurt, no qual ele foi diretor de 1984 a 2004, exatamente 20 anos.

Wear é a última de uma série de peças que Siegmund (2011) identifica como "Complexo de Robert Scott". Robert Scott foi um oficial naval britânico que morreu na volta de uma expedição para a Antártica, em 1912. Sua tentativa de explorar um continente desconhecido, como o Pólo Sul, favorece um paralelo entre esse terreno incógnito e a investigação do balé, daquilo que imaginamos que ele pode ser e o que acontece quando o corpo experimenta essas orientações previstas por padrões criados por normas clássicas. Desbravar o Pólo Sul é como se aventurar por um campo que muda à medida que a expedição começa e se depara com imprevistos que alteram constantemente os caminhos que serão percorridos. Um terreno em constante transformação no qual qualquer tentativa de controle pode resultar na exaustão e no aniquilamento daquele que insiste em estabelecer demarcações e orientações seguras em áreas que se movem constantemente.

O que Sigmund (2011) chama de "Complexo de Robert Scott" é uma possibilidade de reflexão sobre as abordagens de Forsythe no que diz respeito à prática do balé e suas tentativas de escapar da tradição. Wear faz uma analogia entre o balé como modelo abstrato representacional pautado em localizações precisas de posições e movimentos e a aventura de Robert Scott na Antártica. Assim como Scott, Forsythe se confronta com impossibilidades do balé como um sistema estável e abstrato na orientação de percursos do corpo.

O titulo do trabalho, Wear, diz respeito ao vestir e coloca em questão o lugar do balé na sociedade contemporânea. A palavra Wear, vestir, remete ainda a ideia de where, onde, de acordo com Siegmund (2011). Essa relação entre palavras e sentidos trata de problemáticas que abordam a prática e a função dos modelos do balé clássico. Qual a relação desta linguagem codificada com as diferentes características dos corpos dos bailarinos? Qual o lugar do balé?

Wear esboça a tentativa de seguir adiante, de experimentar novas possibilidades criativas e novas referências. A partir desse trabalho, Sigmund (2011) faz uma análise das transformações espaciais que marcam alguns dos trabalhos seguintes de Forsythe. A organização espacial dos dançarinos e o deslocamento da zona de ação do fundo para a frente do palco marcaram o início de importantes transformações em suas propostas.

Wear é uma despedida de uma relação de vinte anos com o Balé de Frankfurt e a abertura para a expansão de referencias menos vinculados a exigências institucionais.

Por motivos financeiros e artísticos a companhia de Balé de Frankfurt foi fechada em 2002 e após grandes repercussões e protestos, foi reaberta em 2003. A reabertura deu início a 
um período de negociações com Forsythe que logo fracassaram e o balé da cidade de Frankfurt foi definitivamente fechado no final de 2003.

Com o fim do Balé de Frankfurt, em 2004, William Forsythe funda a The Forsythe Company. A nova Companhia, formada por artistas do Balé de Frankfurt e por novos integrantes, utilizou por mais alguns anos as salas de ensaio da Ópera de Frankfurt ${ }^{18}$ para a criação de trabalhos. A partir de 2009 o grupo passa a trabalhar na sede localizada no endereço Schmidtstrasse, 12, em Frankfurt.

Ao contrário do Balé de Frankfurt, que era uma companhia municipal, a The Forsythe Company foi fundada como uma companhia público-privada. Isso aconteceu a partir de uma parceria público-privada, o que é raro na Alemanha, que inclui parcerias com os estados de Hesse e Saxônia - com as cidades de Frankfurt e Dresden.

Em matéria publicada por Alan Riding "Frankfurt ballet falls for Forsythe" 19 , na ocasião do encerramento do Balé de Frankfurt:

Ao contrário do Balé de Frankfurt, que trabalhou na ópera de Frankfurt, a The Forsythe Company terá duas residências, o Bockenheimer Depot, em Frankfurt, e o Festspielhaus Hellerau, em Dresden. O subsídio anual virá principalmente dos governos dos estados de Hesse e da Saxônia. (RIDING, 2004, tradução nossa) ${ }^{20}$.

Esse período de mudança do Balé de Frankfurt para a The Forsythe Company marca não só o início de uma fase mais autônoma das obrigações e expectativas institucionais, como afirma um caráter mais experimental na atuação de Forsythe.

Nessa fase, a The Forsythe Company passará a ter como sede dois locais de grande importância para a cena alternativa das cidades de Frankfurt e Dresden, o Bockenheimer Depot e o Festspielhaus Hellerau.

Enquanto seus primeiros trabalhos, e sobretudo, aqueles criados no contexto do Balé de Frankfurt, compõem um vasto repertório que é encenado por inúmeras companhias em diferentes países, as produções mais recentes são desenvolvidas e apresentadas exclusivamente pela The Forsythe Company.

Paralelo ao trabalho desenvolvido junto a The Forsythe Company, Forsythe tem se dedicado a projetos nos quais investiga relações espaciais a partir de objetos, instalações,

\footnotetext{
${ }^{18}$ Informação concedida por Thierry em entrevista no dia 30 de abril de 2015, em Frankfurt am Main.

${ }^{19}$ Texto disponível no link: http://www.smh.com.au/articles/2004/07/06/1089000148669.html?from=storyrhs, por Alan Riding em 7 de Julho 2004. Acesso: setembro de 2015.

${ }^{20}$ Texto original: "Unlike the Frankfurt Ballet, which worked from the Frankfurt opera house, the Forsythe Company will have two homes, the Bockenheimer Depot in Frankfurt and the Festspielhaus Hellerau in Dresden. Its annual subsidy will come mainly from the state governments of Hesse and Saxony."
} 
filmes e propostas interativas que convidam o corpo a diferentes experiências que interferem na percepção. A maior parte desses trabalhos, conhecidos como Objetos Coreográficos, são composições que provocam a desestabilização dos pontos de apoio e de referencias já conhecidos pelo corpo e pelos sentidos. Seus trabalhos têm sido apresentados em festivais, como o Berliner Festspiel ${ }^{21}$, em Bienais, em museus ${ }^{22}$, em teatros, nas ruas de diferentes cidades e transitam de um lugar para o outro em ações que dificultam a categorização de suas propostas. Abordarei alguns desses trabalhos mais detalhadamente nas seções "Lugares em Construção" e "Suspensões".

Além dos projetos, das parcerias e iniciativas que promovem diálogos e cruzamentos entre linguagens como dança, artes visuais, teatro e arquitetura, Forsythe trabalha em colaboração com educadores e especialistas em mídias digitais. E é neste contexto que ele cria, em 1994, em parceria com o Zentrum für Kunst und Medientechnologie, o programa de computação Improvisation Technologies: A Tool for the Analytical Dance Eye, que "é utilizado como método de ensino por companhias profissionais, conservatórios de dança, universidades, programas de pós-graduação e escolas (secundárias; superiores) por todo o mundo." ${ }^{23}$ Esse programa tem como intuito oferecer uma nova opção de documentação, pesquisa e educação em dança.

Ainda vinculado a mídias digitais, Forsythe lança em 2009 o Synchronous Objects for One Flat Thing, reproduced ${ }^{24}$ - um projeto interativo de internet desenvolvido em colaboração com a Universidade do estado de Ohio. Este projeto oferece uma ampla visão interdisciplinar sobre a organização de complexas estruturas que compõem a sua noção de pensamento coreográfico.

William Forsythe, que tem sua carreira marcada por investigações e pesquisas que promoveram importante mudanças de perspectiva da prática e do pensamento do balé, da

\footnotetext{
${ }^{21}$ Este festival acontece anualmente em Berlim e no ano de 2013 aconteceu uma mostra especial de trabalhos da The Forsythe Company e de projetos instalativos de Forsythe. Nesta ocasião entrei em contato, pela primeira vez, com o Objeto Coreográfico White Bouncy Castle.

${ }^{22}$ Seus trabalhos têm sido exibidos em instituições como: "Whitney Biennial (New York), the Venice Biennale, the Louvre Museum, and 21_21 Design Sight in Tokyo. His performance, film, and installation works have been featured amongst others at the Pinakothek der Moderne in Munich, the Migrosmuseum für Gegenwartskunst in Zurich, the Deichtorhallen Hamburg, The Museum of Modern Art New York and the Hayward Gallery in London."

Texto disponível no site: http://www.williamforsythe.de/biography.html. Acesso em março de 2014.

23 "Improvisation Technologies: A Tool for the Analytical Dance Eye, developed with the Zentrum für Kunst und Medientechnologie, is used as a teaching tool by professional companies, dance conservatories, universities, postgraduate architecture programs, and secondary schools worldwide." Texto disponível no site: http://www.williamforsythe.de/biography.html. Acesso em março de 2014.

${ }^{24} \mathrm{O}$ projeto, uma parceria entre William Forsythe and Norah Zuniga Shaw, está disponível no link:

http://synchronousobjects.osu.edu/media/inside.php?p=forsythebio. Acesso em maio de 2014.
} 
dança, da coreografia e da produção em arte, começa o ano de 2015 com mais uma mudança em sua trajetória.

Novos estímulos e reorientações impulsionam o seu retorno para os Estados Unidos. Após um longo período na Alemanha, país no qual desenvolveu a maior parte de sua carreira e onde formou inúmeros artistas, Forsythe retorna para a América. Em 2015 ele finalizou os trabalhos com a The Forsythe Company e assumiu a posição de professor e diretor do departamento de coreografia na Universidade da Califórnia do sul (University of Southern Califórnia) e de coreógrafo associado do Balé da Ópera de Paris (Opera Ballet's). Forsythe tem atuado ainda como educador e professor em universidades e instituições culturais, é pesquisador honorário no Centro Laban de Movimento e Dança, em Londres, e doutor honorário pela Julliard School, em Nova Iorque ${ }^{25}$.

Entre os projetos de Forsythe para a nova fase, um deles é cuidar do seu jardim em Vermont, nos Estados Unidos, onde o coreógrafo tem uma casa. Em Vermont “ eu me ocupo com o jardim, eu tenho uma motosserra e cuido das madeiras"26, diz Forsythe em entrevista.

No mês de abril de 2015 aconteceu no Bockenheimer Depot, em Frankfurt am Main, a última apresentação da The Forsythe Company ${ }^{27}$. A remontagem do trabalho Kammer Kammer $^{28}$ marcou o encerramento das atividades da Companhia e o início de um novo ciclo no percurso de Forsythe.

Forsythe, que consolidou sua carreira em Frankfurt como coreógrafo do Balé de Frankfurt, se despede da cidade com uma grande exposição no Museu de Arte Moderna (Museum für Moderne Kunst). Essa mudança evidencia uma atuação flexível, especulativa e livre de referencias artísticos e institucionais rígidos. A experiência de seus trabalhos em diferentes contextos desprende suas propostas de um único referencial ao mesmo tempo em que imprime um caráter investigativo e processual a sua produção. Há sempre uma linha solta que corre para direções inesperadas, projetos e produções que atravessam fronteiras e que dificultam a localização ou mesmo a estabilização dos trabalhos em um contexto determinado. Forsythe comenta:

\footnotetext{
${ }^{25}$ Informação disponível no site: http://www.williamforsythe.de/biography.html. Acesso em abril de 2015.

${ }^{26}$ Texto original: "I'm gardening, and I have a chainsaw, I take care of the woods". (tradução nossa) Em entrevista a Laura Cappelli: William Forsythe dances to a new tune. Data: 6.03.2015. Acesso em: 30.03.2015. Link: http://www.ft.com/intl/cms/s/0/af9fb9ec-b5d7-11e4-a577-00144feab7de.html\#axzz3Z9qvFGLe

${ }^{27}$ A The Forsythe Company é agora a Dresden Frankfurt Company, que é composta por um grupo inteiramente novo de artistas e por um novo diretor artístico, Jacopo Godani, que trabalhou entre 1991 e 2000 como bailarino do Balé de Frankfurt.

${ }^{28}$ Os integrantes da The Forsythe Company se apresentaram ainda a partir do mês de junho de 2015 com o trabalho "In Act and Thought", no Frankfurt Lab, sob a direção de Fabrice Mazliah. Entretanto, Kammer Kammer encerrou a atuação de Companhia sob a direção de Forsythe.
} 
Uma designação destruiria os fundamentos da dança. Uma vez que algo é fixado como uma forma, tão logo se estabelece: isso será feito, isso será discutido e isso não, assim como acontece no balé clássico, então é o fim. Por exemplo, chega alguém e diz: isso é Tanztheater. E não vê o que fazemos. (FORSYTHE em William Forsythe - Tanz und Sprache, 1993:17, tradução nossa) ${ }^{29}$

Essas zonas de indeterminação trilhadas e sugeridas por Forsythe confundem os referenciais e incitam diálogos de suas propostas com problemática dispersas em diferentes campos, sobretudo, na filosofia. Forsythe desafia o pensamento em equações e procedimentos que ativam a percepção para condições e situações complexas que resultam na aparição e na multiplicação de questionamentos.

Forsythe fala sobre esse deslocamento entre lugares e áreas: "Esta dissolução dos limites entre linguagens é como a dissolução entre estilos na dança: qual é a diferença entre o balé e hip-hop? Balé e tap? Balé e não balé? Não há nenhuma fronteira porque é o corpo. (Forsythe, 2010) ${ }^{30}$.

Sarah Crompton (2015) comenta a sua trajetória e o seu interesse investigativo que confirma aproximações com referenciais filosóficos:

\begin{abstract}
Por todo seu brilhantismo técnico, Forsythe não foi nenhum Balanchine. Seus interesses o jogavam sempre para longe de uma abstração elegante ou de uma narrativa tradicional. "Eu tive que encontrar meu caminho em torno de Balanchine, Petipa, Cranko, MacMillan, todos esses," ele explicou certa vez. "Eu percebi que tinha que seguir adiante." Ele é, portanto, o único coreógrafo que já foi mencionado em uma mesma frase com o filósofo Michel Foucault, por fazer uso de uma inteligência crítica similar na dança e em sua linguagem, solicitando que as pessoas não apenas assistam à dança, mas para analisem o que estão assistindo e entendam o que os bailarinos pensam, como passos são esquecidos, como espaços, formas e composições são criadas. (Crompton, 2015, tradução nossa) ${ }^{31}$
\end{abstract}

\footnotetext{
${ }^{29}$ Em entrevista disponível no livro William Forsythe - Tanz und Sprache, 1993. "Gaby Von Rauner/Rudolf Stäuble, Gespräch mit William Forsythe", 1985. Texto original: "Eine Benennung würde das Wesentliche am Tanz zerstören. Sobald es fixiert wird als Form, sobald man festsetzt: das wird gemacht, das wird diskutiert und nicht das, genau wie klassisches Ballet, dann ist es vorbei. Da kommet zum Beispiel jemand und sagt, das ist Tanztheater und sieht gar nicht, was wir machen."

${ }^{30}$ Entrevista concedida a Roslyn Sulcas no texto "Watching the Ballett Frankfurt, 1988-2009", no livro William Forsythe and the practice of choreography - it starts from any point, organizado por Steven Spier. Texto original: "This dissolution of borders between languages is like the dissolution between styles of dance: what's the difference between ballet and hip-hop? Ballet and tap? Ballet and non-ballet? There is no border, because it is the body." (Forsythe, 2010)

${ }^{31}$ Sarah Crompton no texto "Elevated visions: how William Forsythe changed the face of dance". Matéria publicada em março de 2015. Disponível no link: http://www.theguardian.com/stage/2015/mar/07/in-the-middlesomewhat-elevated-william-forsythe-dance. Acesso em maio de 2015. Texto original: "But for all his technical brilliance, Forsythe was no Balanchine. His interests were always propelling him far away from elegant abstraction or traditional narrative. "I had to find my way around Balanchine, Petipa, Cranko, MacMillan, the whole crowd," he once explained. "I realised I had to move on." He is consequently the only choreographer who has ever been mentioned in the same sentence as the philosopher Michel Foucault, applying a similar critical intelligence to the nature of dance and its language, asking people not just to watch dance, but to analyse what they are watching and understand how dancers themselves think, how steps are forged, how spaces, shapes and scores are created. (Crompton, 2015)
} 
Em sua trajetória as incursões espaciais e os experimentos no palco da Ópera de Frankfurt revelam um percurso investigativo que agirá na ativação de elementos ao mesmo tempo em que desafiará padrões e ordens instituídas.

Sua atuação junto à Ópera de Frankfurt, como diretor do balé da cidade de Frankfurt entre os anos 1984 e 2004, sinaliza o desenvolvimento de importantes características em sua prática que, de algum modo, determinarão as suas escolhas, procedimentos de criação e abordagens espaciais, estejam estas localizadas no corpo do bailarino ou em composições espaciais.

Gerald Siegmund (2004) ${ }^{32}$ pontua ainda que William Forsythe entra em contato com o balé e com a forma como ele foi encenado durante séculos e trabalha a partir daí propondo abordagens inovadoras que não invalidam a própria tradição do balé. Forsythe tomou a liberdade de atuar contra o já conhecido e investigar o que há de invisível e até então desconhecido no balé. Ele se apropria das referências clássicas da dança, como um pesquisador, faz uma análise detalhada e apresenta o resultado publicamente, afirma Siegmund (2004).

Alguma questões que surgem nas práticas propostas por Forsythe podem ser observadas nas seguintes perguntas: Como que o corpo se move? Como me movo? Quais estímulos acionam o corpo? Desloco-me a partir de espaços que considero internos em meu corpo? Desloco-me a partir de estímulos exteriores? Há realmente espaços internos e externos? Ou meus deslocamentos nascem do diálogo ou dessa dinâmica entre aquilo que de forma analítica delimito como dentro e fora. $\mathrm{O}$ que estimula o movimento? Como abrir a percepção para as relações e estímulos ambientais? Como colocar o corpo em movimento? Como acionar deslocamentos não cotidianos? Pode-se dizer que essas questões trazem ainda à tona a presença do sujeito sob uma perspectiva deleuziana de assujeitamento, que contesta o sujeito originário e uno - problemática que irá permear a produção de Forsythe. Suas propostas, ao assumirem sujeito e objeto como instâncias que se organizam em relações dialógicas nas quais ambos surgem como agentes inseridos em um campo dinâmico de perturbações e variações ambientais, prevêem considerações sobre um sujeito empoderado que se desvincula de padrões de normatização e se constitui em contextos de troca. Nas práticas de Forsythe, o assujeitamento age no empoderamento daquele que participa da ato, seja ele artista ou espectador. Pode-se dizer ainda que essa dimensão aparece implícita e entrelaçada ao seu conceito de coreografia, que está em constante transformação e que é experimentado em

\footnotetext{
${ }^{32}$ No livro "Denken in Bewegung", 2004.
} 
diferentes trabalhos e linhas investigativas.

Desde seus primeiros trabalhos que Forsythe se propõe investigar corpo, sujeito, espaço e qualidades ambientais em procedimentos nos quais ele especula articulações que constituirão sua noção de coreografia. Se vetores que escapam do corpo ou se estímulos que atravessam o espaço, o que interessa é o estudo dessa complexa rede de relações na qual sujeito, objeto e espaço se distribuem em ações que extrapolam organizações hierárquicas.

Neste movimento de mão dupla que prevê a investigação de linhas que orientam deslocamentos do corpo e a produção de espacialidades, Forsythe experimenta articulações espaciais cênicas que desprendem o balé clássico das formações previsíveis ao mesmo tempo em que se dispõe pesquisar as orientações objetivas propostas por este sistema. Ele investiga novas possibilidades de relação e ocupação da área do palco sem abrir mão de uma pesquisa objetiva e analítica dos vetores estabelecidos pelo balé clássico como ponto de partida para o mapeamento e descoberta de novas condições para a produção de movimentos.

Vale à pena mencionar ainda que suas inquietações confrontam a produção de arte com o mundo. De um lugar reservado a arte passa a interagir diretamente com o ambiente e suas variações. A arte transita entre estações, surge e some. Entretanto, há na produção de Forsythe escolhas e caminhos ambíguos e contraditórios. Essas abordagens conflituosas aparecem em projetos nos quais o controle e a objetividade dos meios beira ao mecanicismo, o que iria de encontro as suas premissas fenomenológicas e relacionais. Embora não seja o foco desta pesquisa, seu interesse por mecanismos tecnológicos e aparatos que contam com fórmulas e sistemas operacionais precisos criam tensões entre o desejo pelo controle e a experiência do indeterminado.

\section{Volumes e vetores no palco}

A prática de Forsythe coincide com a investigação de possibilidades espaciais que começam no palco em formações e deslocamentos que reposicionam ordens e parâmetros instituídos ao mesmo tempo que evidenciam desdobramentos entre corpo e espaço. As relações entre corpo e espaço aparecem como formações volumosas na qual forças e vetores interagem entre si e produzem espacialidades que rompem com estruturas já conhecidas. Suas experiências no palco de Frankfurt anunciam um longo processo de pesquisa no qual o coreógrafo lançará mão dos mais variados meios para investigar espacialidades vinculadas ao movimento e à percepção. 
Gerald Siegmund (2010), no texto "Körper, Heterotopie und der begehrende Blick"33 dá ênfase à fascinação de William Forsythe pelas possibilidades apresentadas pelo enorme palco da Ópera de Frankfurt, quando aceitou trabalhar como diretor do Balé de Frankfurt, em 1984. O espaço do teatro de Frankfurt favorecia a desarticulação dos alinhamentos e das distribuições espaciais e sociais que se impunham na plateia e no palco dos teatros barrocos. Forsythe se defronta com uma grande caixa preta na qual o espaço do palco se abre às mais diversas articulações espaciais e na qual a ordem social e hierárquica do público se confunde no escuro da sala.

Com a divisão do espaço de teatro em uma área de palco elevada com passagens laterais e uma plateia escurecida, permitindo apenas um confronto frontal da plateia com o palco, este espaço não é idêntico a caixa de palco barroca e sua orientação restrita sob um ponto de fuga. (SIEGMUND, 2010:131, tradução nossa) ${ }^{34}$

O palco da Ópera de Frankfurt difere da proposta espacial colocada pela caixa de palco barroca e favorece a construção de novas direções para o olhar. Novas articulações espaciais no palco reverberarão na construção de novas relações entre obra e espectador. Muito embora a caixa preta apresentasse suas limitações e a imposição de uma linha divisória que separa obra e público.

Ainda sobre o modelo de organização barroco e a formatação do balé como uma prática vinculada ao palco e a uma ordem específica do olhar e do movimento, Sigmund discorre sobre as formações e aos modelos sociais absolutistas:

Esta formação social foi, além disso, consolidada através do estabelecimento de um determinado regime do olhar, que posiciona cada sujeito em um certo lugar em relação ao centro - a ficção do rei como sendo um ponto de fuga no infinito de um olhar reflexivo. Essa direção hierárquica do olhar corresponde a uma prática coreográfica que coloca o evento no palco sob a perspectiva de em um eixo central simétrico. (SIEGMUND, 2010:131, tradução nossa) ${ }^{35}$.

Os desenhos que se configuram no palco e na plateia evidenciam hierarquias, definem

\footnotetext{
${ }^{33}$ Texto disponível no livro “Theater Ohne Fluchtpunkt”, organização: Gabriele Brandstetter e Birgit Wiens, 2010 .

${ }^{34}$ Texto original: "Mit der Zweiteilung des Theaterraumes in einen erhöhten Bühnenraum mit Seitengassen und einen angedunkelten Zuschauerraum, der lediglich eine frontale Gegenüberstellung der Zuschauer mit der Bühne erlaubt, ist dieser Raum zwar nicht identisch mit der barocken Kulissenbühne und ihrer strengen Ausrichtung auf einen Fluchtpunkt." (Siegmund, 2010:131).

${ }^{35}$ Texto original: "Diese Gesellschaftsformation ist zudem durch die Etablierung eines bestimmten Blickregimes gefestigt worden, das jedem Subjekt einen bestimmten Platz im Hinblick auf das Zentrum- die Fiktion des Königs als das sich im Unendlichen des Fluchtpunkts spiegelnde Auge - zuordnet. Dieser hierarchischen Lenkung des Blicks entspricht eine choreographische Praxis, die das Geschehen auf der Bühne um eine Mittelachse herum symmetrisch anordnet." (Siegmund, 2010:131)
} 
estruturas sociais e impõem um regime restrito para o olhar. Essas orientações espaciais que direcionam o corpo e o olhar são heranças de uma ordem absolutista que dá ênfase à centralização do poder, à regulamentação de normas, às divisões, às cisões e à produção de lugares que não se comunicam. Os padrões que se manifestam no palco estruturam também as tramas e as regras sociais que estão em jogo nos modelos e ordens absolutistas.

Quando Forsythe aceita o convite para trabalhar como diretor do Balé de Frankfurt, as exigências e os referenciais tradicionais do balé regulavam ainda os procedimentos e as produções da Companhia. Mesmo que o palco e o espaço do teatro não apresentassem as configurações impostas pelo sistema rígido barroco, o balé afirmava-se ainda como um conjunto estável de movimentações que delimita, com clareza, o seu campo de atuação. Em seu período de atuação junto ao Balé de Frankfurt, Forsythe se lançará ao desafio de deslocar o olhar do espectador para direções não previstas. Ele desmontará modelos e colocará em questão às normas impostas pelo balé.

Forsythe se apropria do palco como área na qual se articulam camadas e se entrelaçam diferentes elementos. Um campo heterogêneo é produzido na relação entre volumes, intensidades e contrastes que se tencionam entre si e acionam o surgimento de um campo dinâmico, cinético, plural e tridimensional que supera os esquemas bidimensionais e frontais na relação com o espectador. Regras e aglutinações homogêneas, que prevêem a manutenção de ordens e modelos instituídos, dão lugar a produções que dão ênfase aos aspectos heterogêneos, contraditórios e aos contrastes que produzem espacialidades.

Forsythe atua na articulação e na dinamização de elementos e estruturas que foram intensamente discutidas e favoreceram o surgimento de novas perspectivas para o teatro moderno. Essas perspectivas imprimiram ao espaço ativações ou abordagens que geraram diferentes caminhos para a produção de arranjos espaciais performativos. Juliet Ruffort comenta:

\footnotetext{
Ao romper os laços que prendiam o teatro ilusionista às normas burguesas e ao ponto de vista fixo da autoridade, encenadores de teatro das vanguardas históricas rejeitaram representações de perspectivas centrais da vida como um propagandismo. (...) Para se oporem a ilusão realista, alguns encenadores de teatro procuraram uma forma totalmente diferente para o espaço de atuação. (RUFFORT, 2015:51, tradução nossa $)^{36}$.
}

\footnotetext{
${ }^{36}$ Texto original: "Breaking the ties that bound illusionistic theatre to bourgeois norms and the fixed eye-point of authority, theatre-makers of the historical avant-gardes rejected centred, perspectival representations of life as a propagandist. (...) To oppose the realist illusion, some theatre-makers sought a wholly different form of performance space." (Ruffort, 2015:51)
} 
O palco de Frankfurt aparece como o campo cinético que o incitará às mais variadas criações e especulações espaciais. Esse espaço múltiplo, disperso e instável é como um desenho que evidencia percursos e oscilações do corpo. Um corpo temporal e espacial, um espaço que é produzido em movimento.

Retornando às considerações sobre o palco de Frankfurt, o espaço do palco, no contexto da caixa preta, tende a apresentar o corpo como uma imagem frontal e bidimensional. Essa tendência é questionada logo nos primeiros trabalhos de Forsythe:

\begin{abstract}
Neste espaço de palco William Forsythe dispõe os dançarinos de sua companhia de balé. Seu primeiro grande trabalho para o Balé de Frankfurt se comprometeu com uma visão na qual todos direcionavam o seu olhar sempre para o palco. Então Forsythe no segundo ato de Artifact (1984) organizou o espaço do tablado (palco) de tal modo que uma cortina caía várias vezes no meio da cena. Desta forma, a visão contínua era interrompida. À audiência foi oferecida uma sequência de imagens individuais, que foram reconstruídas sob diferentes princípios geométricos. O corpo de baile se formava algumas vezes como triângulo, algumas vezes como quadrilátero e outras como moldura para os dois Pas de Deux centrais onde a duplicação do centro era exposta pela dinamização do olhar dentro do painel. (SIEGMUND, 2010, P.132, tradução nossa) ${ }^{37}$.
\end{abstract}

Sobre os trabalhos iniciais é importante mencionar ainda as aberturas que de algum modo provocavam desequilíbrios e a construção de novos pontos de vista:

Roslyn Sulcas $(2011)^{38}$ comenta que os questionamentos e inquietações de Forsythe são fundamentais em seus processos investigativos e na descoberta de novos pontos de vista para a observação e experiência do corpo, da dança e do espaço. Sulcas fala sobre a relação de Forsythe com limites e modelos que restringem conceitos e abordagens:

Quais são as possibilidades do corpo que dança? O que faz uma dança? O que é performance? Como você encontra o que você não conhece ou compreende dentro da categoria do já conhecido? O constante levantamento dessas perguntas e um subsequente desrespeito com as normas estéticas e físicas de qualquer um estilo particular de movimento - ou mesmo a limitar as origens de sua coreografia ao campo da dança - tem consistentemente marcado o trabalho de Forsythe, desde o início dos balés em Frankfurt até os recentes, muitas vezes peças da The Forsythe

\footnotetext{
${ }^{37}$ Texto original: "In diesen Bühnenraum hinein platzierte William Forsythe die Tänzerinnen und Tänzer seiner Ballettkompanie. Seine ersten großen Arbeiten für das Ballet Frankfurt beschäftigten sich alle immer auch mit dem Blick auf die Bühne. So hatte Forsythe im zweiten Akt von Artifact (1984) das Kompositionsprinzip des Tableaus regelrecht ausgestellt, indem er den eisernen Vorhang mehrmals mitten in einer Szene herunterfallen ließ. Auf diese Weise wurde das Sehkontinuum unterbrochen. Den Zuschauern bot sich eine Abfolge von einzelnen Bildern, die nach jeweils unterschiedlichen geometrischen Prinzipien aufgebaut waren. Das Corps de ballet bildete mal ein Dreieck, mal ein Viereck als Rahmen um die beiden zentralen Pas de deux, wobei durch diese Verdoppelung des Zentrums eine Dynamisierung des Blicks innerhalb des starren Tableaus erzielt wurde." (Siegmund, 2010:132)

${ }^{38}$ No texto Watching the Ballett Frankfurt, 1998-2009, disponível no livro William Forsythe and the Practice of Choreography. Organizados por Steven Spier, 2011.
} 
Company difíceis de categorizar. (SULCAS, 2011: 18, tradução nossa) ${ }^{39}$

Gerald Sigmund (2004), no texto "William Forsythe: Räume eröffnen, in denen das Denken sich ereignen kann" ${ }^{\text {, }}$, afirma que desde as suas primeiras criações existiam passagens abertas à improvisação. Esses lugares incompletos, presentes ainda hoje em suas propostas, surgem como catalisadores de decisões que reorientam dinâmicas e provocam abalos na estrutura geral do trabalho. Os dançarinos, antes e durante as apresentações, são incentivados a tarefas que auxiliam na descoberta de movimentações que emergem de escolhas vinculadas à percepção e à multiplicidade de pensamentos que cada corpo experimenta ao gerar registros espaciais. Sigmund explica:

\begin{abstract}
Uma tarefa durante os ensaios é, portanto, sensibilizar os dançarinos através de um sistema de reorientação espacial e física do movimento para que eles desenvolvam suas próprias sequências e movimentos. Os dançarinos devem fazer de seus corpos instrumentos do pensamento. E esse processo de pensamento se realiza diante dos nossos olhos enquanto estamos sentados na plateia. $\mathrm{O}$ que vemos não são produtos acabados, mas as decisões, caminhos que são tomadas e têm um impacto sobre as possibilidades dos outros dançarinos. O que vemos é, portanto, um modelo de interação humana e um modelo de comunicação democrático. (SIEGMUND, 2004: 59 , tradução nossa) $)^{41}$
\end{abstract}

É importante pontuar que a noção de pensamento apresentada aqui corresponde às sobras, àquilo que escapa às estruturações lógicas e estáveis. O conceito de pensamento que entra em jogo corresponde a um processo complexo de elaborações, escolhas e dinâmicas que acontecem no corpo e em suas interações com o meio. Gerar pensamentos é oferecer ao corpo condições para experimentar desvios e trajetos imprevisíveis. É desacelerar, suspender, girar em diferentes direções, alterar rapidamente os pontos de apoio, iniciar o movimento pelo ponto onde geralmente ele termina, é descobrir começos e finais que reverberam e conduzem o gesto adiante, é abandonar o percurso conhecido e lançar o olhar para terrenos

\footnotetext{
${ }^{39}$ Texto original: "What are the possibilities of the dancing body? What makes a dance? What is performance? How do you find what you don't know or understand within the category of the known? The constant posing of these questions and a subsequent disregard for the aesthetic and physical norms of any one particular style of moviment - or indeed to confine the origins of his choreography to the field of dance - has consistently marked Forsythe's work, from the early Stuttgart ballets to the recent, often hard-to-categorize The Forsythe Company pieces." (Sulcas, 2011:18)

${ }^{40}$ Texto disponível no livro "William Forsythe, Denken in Bewegung”, Organizado por Gerald Siegmund, 2004.

${ }^{41}$ Texto original: "Aufgabe während der Proben ist es daher, duch das System der räumlichen und körperlichen Reorientierung Von Bewegun die Tänzer dahingehend zu sensibilisieren, dass sie ihre eigenen Schritt - und Bewegungsfolgen entwickeln. Die Tänzer sollen ihre Körper zu Instrumenten des Denkens machen. Und genau dieser Denkprozess vollzieht sich, während wir im Zuschauerraum sitzen, vor unseren Augen. Was wir sehen, sind keine fertigen Produkte, sondern Entscheidungen, Wege, die eingeschlagen werden und die Auswirkungen haben auf die Möglichkeiten der anderen Tänzer. Was wir sehen, ist mithin ein Modell menschlicher Interaktion und ein Modell von demokratischer Kommunikation. (Siegmund, 2004: 59)
} 
desconhecidos, é permitir que o corpo experimente paragens e que retome o salto de lugares inexistentes.

É possível afirmar então que o primeiro desafio de Forsythe em Frankfurt, quando assume a direção do balé de Frankfurt, é explorar as possibilidades da estrutura do palco. Uma caixa preta e o palco como superfície geométrica e regular. É neste espaço que Forsythe irá explorar relações com o solo e a desarticulação de alguns princípios fundamentais do balé clássico. Os eixos que orientam e centralizam o corpo e o olhar serão distribuídos, sofrerão interrupções, vagarão e fugirão dos pontos de fuga e observação já conhecidos. Desorientações transformarão a área de atuação, a superfície do palco ganhará volume, intensidade, peso e novas linhas redesenharão os lugares comuns do balé clássico.

Forsythe se interessa por possibilidades coreográficas, por variações entre corpo e espaço, e o palco da Ópera e Frankfurt será seu laboratório, a sala de trabalho e pesquisa onde serão desenvolvidos seus experimentos junto ao balé de Frankfurt. Deste modo, é possível afirmar que Forsythe trabalha, desde a sua atuação como coreógrafo do Balé de Frankfurt, com condições dinâmicas que acontecem tanto na estrutura do corpo dos bailarinos quanto no palco. A centralidade, o eixo estável se multiplica em zonas trepidantes nas quais as ações dos corpos e as ordens previstas para a ocupação da área do palco serão deformadas e transformadas em vibrações de uma paisagem sem ponto de fuga e em constante transformação.

Como quem desenha pensamentos e articulações possíveis entre elementos e situações, Forsythe dispõe linhas sobre o palco, desloca e gera figuras que colidem, lança o olhar do espectador para o centro e para a periferia. Remonta arranjos, rabisca estruturas que escapam do espaço delimitado do palco. Avança, faz vibrar o espaço e aciona lugares por onde transitam vozes, pensamentos e sons. Seu espaço surge da sobreposição de lugares visíveis e invisíveis, de matérias e vestígios de memórias, de encontros e acasos.

Neste contexto, Forsythe investiga o balé para além das normas e dos pressupostos impostos por regras e sistemas sociais - que se vinculam ao surgimento da sua prática. O balé diz respeito às possibilidades do corpo no espaço. Os deslocamentos, as linhas, os trajetos, os ângulos e as qualidades que surgem nos intervalos entre corpo e espaço sugerem os mais variados sistemas que organizam e lançam o corpo à negociações e interações espaciais. $\mathrm{O}$ balé surge como um entre tantos outros sistemas de organização de músculos e ossos que se articulam no espaço criando eixos, suspensões e oscilações que favorecem a criação de percursos que não são percorridos cotidianamente. O balé é abordado como um procedimento, como ponto de partida, para o desdobramento de possibilidades do movimento. E é sob esse 
ponto de vista que Forsythe passará a utilizar diferentes referencias objetivos e subjetivos de orientação para desdobramentos e articulações possíveis do corpo.

\section{Corpo- espaço - corpo}

A observação de aspectos que se manifestam no ambiente chama a atenção para o estudo e investigação do corpo sob um ponto de vista material que leva em consideração massa, volume, peso, ritmo, velocidade e demais características e qualidades que arquitetam o corpo.

É importante destacar ainda que a observação de linhas, pesos e demais qualidades espaciais confere à prática de Forsythe diálogos e aproximações com a arquitetura. Essa relação com aspectos arquitetônicos auxilia na construção de perspectivas para a análise e experiência do corpo e do espaço.

Forsythe lança mão dos mais variados referenciais para investigar qualidades que desafiam o corpo a encontrar novos percursos e modos de se mover e se relacionar com o ambiente. Nesse processo aparecem referências do balé, do sistema Laban, de mídias que possibilitam a análise do movimento e demais estímulos que auxiliam na observação e experiência de trajetórias e percursos no corpo e no espaço.

Abordagens objetivas e subjetivas se sobrepõem em um emaranhado volumoso que acompanha as transições e os deslocamentos espaciais. O ambiente é estímulo e desenho de linhas, estruturas, pontos e dispersões que geram possibilidades múltiplas para os sentidos. A observação de aspectos objetivos auxilia na construção de desenhos mais complexos e na investigação de qualidades que ampliam o repertório do olhar e do corpo em suas ambulações pelo espaço.

Entre os referenciais que auxiliam na produção de possibilidades espaciais, o balé clássico e o Sistema Laban contribuem com a especulação de aspectos e qualidades que são investigadas a partir de orientações geométricas. Enquanto instruções do balé clássico tendem a se fundamentar em princípios e técnicas que se pautam na repetição e na manutenção de formas e posições, o Sistema Laban promove incursões pelo espaço a partir do referenciais que exploram de modo mais deliberado aspectos da tridimensionalidade que ampliam as possibilidades do corpo no espaço. 


\section{O balé}

De acordo com Steven Spier (2011), o balé clássico é uma estrutura na qual o corpo é dividido em partes que são conectadas a partir de trajetos ou padrões estabelecidos. Essa característica analítica do balé possibilita o desenvolvimento de um alto grau de complexidades formais e técnicas, nas quais o bailarino clássico é conduzido pela imaginação de linhas, arcos e vetores que o localizam espacialmente e o possibilitam saber como precisão o lugar de cada parte do seu corpo em um espaço tridimensional. O autor pontua ainda que a atuação de William Forsythe junto ao Balé de Frankfurt coincide com uma ação investigativa de princípios e fundamentos do balé para a organização do corpo. Neste caso, as técnicas clássicas aparecem como estruturas que não são um fim em si mesmas, mas sim dispositivos ou estímulos para o estudo e prática dos modos pelos quais os corpos se deslocam, se movem, interagem e criam espacialidades.

Em entrevista a Kaiser ${ }^{42}$, Forsythe fala sobre seu método, sobre a descoberta de novos modos de se mover e sobre o uso de linhas e torções que surgem a partir do balé em suas práticas:

\begin{abstract}
Meu método básico, desenvolvido ao longo de um período de 15 anos, é encontrar maneiras de usar o que os meus dançarinos já sabem. Como eu trabalho, principalmente, com bailarinos, eu analiso o que eles sabem sobre o espaço e sobre os seus corpos a partir de formação intensiva em balé. Eu percebi que, fundamentalmente, os bailarinos são ensinados a combinar linhas e formas no espaço. Então, comecei a imaginar linhas no espaço que poderiam ser dobradas, ou lançadas, ou de outra maneira distorcidas. Ao mover de um ponto para uma linha, de um plano para um volume, eu era capaz de visualizar um espaço geométrico composto por pontos que estavam amplamente interligados. Como todos estes pontos estavam contidos dentro do corpo do dançarino, não havia realmente nenhuma transição necessária, apenas uma série de "dobras" e "desdobramentos" que produziam um número infinito de movimentos e posições. A partir daí, começamos a catalogar o que corpo podia fazer. E para cada nova peça coreografada, nós desenvolveríamos uma nova série de procedimentos. Alguns destes procedimentos trabalhavam com o que já está no balé. Se você analisar a posição básica do balé, quando as mãos são mantidas sobre a cabeça, você percebe que existem duas curvas envolvidas, uma à direita e outra à esquerda. Você pode criar inúmeras transformações a partir desta simples posição, que é dada pelo balé e que pode agir e pode agir como uma estrutura chave. Você pode estendê-la para o espaço, ou deixá-la se mover através do corpo como continuação natural das curvas. Além disso, você pode fazer ainda com que os dançarinos percebam as relações entre qualquer dos pontos nas curvas e quaisquer outras partes de seus corpos. O que reduz na performance é o dançarino ilustrando a presença dessas relações imaginadas ao se mover. E no processo descobrir novas maneiras de se mover. $\mathrm{O}$
\end{abstract}

${ }^{42}$ Conversa entre Forsythe e Kaiser que foi gravada em 1998 e publicada posteriormente em Performance Research, v4\#2, verão de 1999.

Texto disponível no site: http://openendedgroup.com/writings/danceGeometry.html. Acesso em junho 2015. 
que isso realmente faz What Na verdade ele faz é para fazer você esquecer como se mover. Você para de pensar sobre o resultado final, e começar a pensar, em vez disso, sobre a execução do movimento internamente. Isso é o que extrapola seu corpo para além dos seus "rigores", por assim dizer. (Conversa entre Kaiser e William Forsythe, 1998, tradução nossa) ${ }^{43}$

Sobre as torções, Forsythe comenta ainda que elas derivam de relações complexas que estão presentes em posições e movimentos do balé clássico. As linhas que cruzam e determinam posições avançam e novos esboços são traçados. Novas regras e paradigmas passam a compor um campo de ação que se expande para além dos contornos do corpo. As linhas que se cruzam entre ossos, músculos, tendões e órgãos se espalham pelo espaço, criam percursos imprevisíveis e geram qualidades espaciais que confirmam a presença de um processo contínuo de transição e transformação entre corpo e espaço. Esse processo coincide com a superação de dicotomias ao mesmo tempo em que prevê continuidades do corpo no espaço e espaço e vice-versa. Nas palavras de Forsythe:

Pegue a posição de ballet épaulement, que é o máximo da realização dos grandes bailarinos. Ela implica um enorme número de contra-rotações determinados pelas relações entre o pé, a mão e a cabeça, e até mesmo dos olhos. Como na dança clássica indiana, ele dita regras de olhar além do corpo. Para mim épaulement é a chave para ballet porque exige a torção mais complexa. As mecânicas do épaulement são o que dão ao balé suas transições internas. (Conversa entre Kaiser e William Forsythe, 1998, tradução nossa) ${ }^{44}$

\footnotetext{
${ }^{43}$ Texto original: "My basic method, developed over a period of 15 years, is to find ways to use what my dancers already know. Since I work primarily with ballet dancers, I analyze what they know about space and their bodies from their intensive ballet training. I've realized that in essence ballet dancers are taught to match lines and forms in space. So I began to imagine lines in space that could be bent, or tossed, or otherwise distorted. By moving from a point to a line to a plane to a volume, I was able to visualize a geometric space composed of points that were vastly interconnected. As these points were all contained within the dancer's body, there was really no transition necessary, only a series of "foldings" and "unfoldings" that produced an infinite number of movements and positions. From these, we started making catalogues of what the body could do. And for every new piece that we choreographed, we would develop a new series of procedures. Some of these procedures worked with what is already in ballet. If you analyze the basic ballet position where the hands are held over the head, you realize that there are two curves involved, one on the right and the other on the left. You can create innumerable transformations from that simple position, which is a given in ballet, and can act like a keyframe. You can extend it out into space, or by let it move through the body as a natural continuation of the curves. You can also make dancers perceive the relationships between any of the points on the curves and any other parts of their bodies. What it boils down to in performance is the dancer illustrating the presence of these imagined relationships by moving. And in the process discover new ways of moving. What it actually does is to make you forget how to move. You stop thinking about the end result, and start thinking instead about performing the movement internally. That's what pulls your body through its "rigors," as it were." (William Forsythe, 1998) Conversa publicada no texto "dance geometry (forsythe)".

Disponível no link: http://openendedgroup.com/writings/danceGeometry.html. Acesso em junho 2015.

${ }^{44}$ Texto original: "Take the ballet position of épaulement, which is the crowning accomplishment of great ballet dancers. It entails a tremendous number of counter-rotations determined by the relationships among the foot, hand, and head and even of the eyes. As in Indian classical dancing, it dictates rules of gazing past the body. For me épaulement is the key to ballet because it demands the most complex torsion. The mechanics of épaulement are what give ballet its inner transitions." (Conversa entre Kaiser e William Forsythe, 1998).
} 
Sobre as transformações que surgem na abordagem de Forsythe do balé clássico, Sarah Crompton $^{45}$ fala sobre a atuação a sua no final da década de 1980, mais especificamente em 1987, com a montagem de "In the Middle", que seria parte de um trabalho maior, Impressing the Czar - que explora o declínio da civilização ocidental e é também uma celebração à força da dança. Crompton observa que In the Middle, Somewhat Elevated, mesmo com sua aparência moderna e abordando um tema tradicional, parece representar uma ordem clássica se inclinando em direção à mudança e ruptura ${ }^{46}$. Ainda no texto de Crompton, Forsythe descreve o trabalho como um processo de:

estender e acelerar as figuras tradicionais de balé. Ao mudar o alinhamento de posições e a ênfase de transições, os enchainments começam a inclinar obliquamente e receber uma unidade inesperada que os faz parecer em desacordo com suas origens. ${ }^{47}$ (Forsythe em entrevista a Crompton, 2015)

A autora descreve o trabalho a partir da imagem de seis mulheres e três homens que se deslocam pelo palco "como criaturas ferozes que exploram um espaço alienígena". Esses nove corpos que transitam deliberadamente pelo espaço em diferentes direções suspendem a frontalidade do balé clássico ao mesmo tempo em que fazem emergir uma teatralidade que aparece na superação de convenções e pontos de apoios que estabilizam o olhar e o foco do espectador.

Crompton $^{48}$ menciona a declaração de Agnès Nolteniuss ${ }^{49}$, que foi uma das bailarinas de Forsythe neste trabalho, sobre as rearticulações sugeridas por Forsythe no contexto acima e no final da década de oitenta:

Forsythe nos pediu para pensar sobre a relação geométrica entre as diferentes partes do corpo. Ele não quer que as pessoas dancem como um bloco, mas que realmente articulem cada parte do corpo.

"É uma maneira diferente de pensar sobre a dança e o que o corpo pode alcançar. Ele chega num ponto onde você pode ver que as pessoas não podem ir adiante. $\mathrm{O}$ corpo não pode fazer mais nada. Isso é o que torna a peça tão forte. (Agnès Noltenius em texto de Sarah Crompton, 2015, tradução nossa) $)^{50}$

\footnotetext{
${ }^{45}$ Sarah Crompton. Elevated visions: how “William Forsythe changed the face of dance". Disponível no site: http://www.theguardian.com/stage/2015/mar/07/in-the-middle-somewhat-elevated-william-forsythe-dance. Acesso em maio de 2015. Matéria publicada em Março de 2015.

${ }^{46}$ Texto original: "seems to represent a classic order tilting towards change and disruption."

${ }^{47}$ Texto original disponível na entrevista de Sarah Crompton: "extending and accelerating the traditional figures of ballet. By shifting the alignment of positions and the emphasis of transitions, the enchainments begin to tilt obliquely and receive an unexpected drive that makes them appear at odds with their origins."

${ }^{48}$ Idem 43.

${ }^{49}$ Agnès Noltenius é bailarina e dançou com o Balé de Frankfurt.

${ }^{50}$ Texto original disponível na entrevista de Sarah Crompton: "Forsythe asked us to think about the geometric relationship between different parts of the body. He doesn't want people to dance as one block, but to really
} 
Os procedimentos de Forsythe buscam alternativas para o movimento ao mesmo tempo em testam limites do corpo. O que o corpo é capaz de produzir em seus deslocamentos espaciais é um de seus principais eixos investigativos.

O exercício a partir de linhas e perspectivas difusas redefine o espaço do palco ao mesmo tempo em que cria camadas, intensidades e forças que operam para além dos esquemas bidimensionais. As relações geométricas sugeridas entre as partes do corpo avançam para a criação de novas composições e orientações espaciais no palco do mesmo modo que novas articulações espaciais reverberam no corpo dos dançarinos.

Quando William Forsythe, que estudou balé clássico na Joffrey Ballet School, em Nova Iorque, se refere aos referenciais e a presença do balé em suas produções, ele diz: "Eu falo a linguagem. Eu não recito a língua"51. Com essa afirmação Forsythe dá ênfase às rearticulações e experimentações que aparecem em seus trabalhos. A estrutura desta ordem clássica é utilizada por Forsythe como orientação para um estudo analítico e detalhado do movimento e não como produto ou resultado final que chegaria ao público como a exibição de um conjuntos de regras e movimentações conhecidas.

A autora Roslyn Sulcas ${ }^{52}$ fala sobre a primeira vez em que assistiu a uma produção de Forsythe, quando o Balé de São Francisco levou New Sleep para Paris, em 1988: “Eu fiquei paralisada, espantada que o balé poderia ter essa aparência: as linhas de corpos escuros e brilhantes de mulheres cortando as diagonais de luz, o gesto enigmático do trio central, movimentos em multicamadas que eu nunca havia imaginado." ${ }^{53}$

Sulcas (1995) pontua ainda que o trabalho com dançarinos formados em balé clássico foi o ponto de partida de Forsythe para o mapeamento e a investigação de novas possibilidades para o movimento. Sulcas comenta:

Trabalhando com bailarinos de formação clássica, ele reinventou maneiras de articular os princípios de balé ignorando a lógica que rege a ordem e os impulsos dos passos, de modo que qualquer parte do corpo pode determinar impulso e

articulate each part of the body." "It is a different way of thinking about dance and what the body can achieve. It arrives at a point where you can see people can't go any further. The body can't do any more. That is what makes the piece so strong." Agnès Noltenius no texto "William Forsythe changed the face of dance" de Sarah Crompton.

\footnotetext{
${ }^{51}$ Texto original: "I speak the language. I don't recite the language”. Fala disponível no texto "The Space of memory", de Gerald Siegmund, no livro "William Forsythe and the Practice of Choreography", 2011: 129. Organizado por Steven Spier.

52 Texto Roslyn Sulcas - Kinetic Isometries.

${ }^{53}$ Texto original: "I was transfixed, amazed that ballet could look like this: the lines of shiny dark-bodies women slashing down the diagonals of light on point, the enigmatic gesture of the central trio, multi-layered moviments that I had never begun to imagine." Roslyn Sulcas - Kinetic Isometries.
} 
direção, e qualquer tipo de movimento pode coexistir e ser integrado em um vocabulário clássico. (SULCAS, 1995, tradução nossa) ${ }^{54}$.

Os trabalhos de Forsythe, que nos anos 80 e início dos anos 90 traziam ainda informações e referenciais diretos do balé clássico, logo se apresentarão como uma intenso processo investigativo sobre os modos como os movimentos podem ser gerados e compostos. Um amplo vocabulário de técnicas e métodos complexos geradores de movimentos foi criado por Forsythe e seus dançarinos. Este mapeamento de estímulos e a observação de uma multiplicidade de pontos que redirecionam o movimento foi transformado em um projeto de computação gráfica, o Improvisation Technologies, a tool for the Analytical Dance Eye, de 1999, que auxilia os novos integrantes da companhia na elaboração de dinâmicas que coincidem com os interesses e as orientações de trabalho de Forsythe. Comentarei sobre esse projeto ainda nesta seção.

O balé clássico, que foi fundado sob estruturas e modelos sociais hierárquicos, parece já não ter função dentro das perspectivas sociais que vivemos. Reinventá-lo é organizá-lo a partir de novas perspectivas, é experimentar relações nas quais o corpo se apresenta como matéria, como tecido complexo que se alastra pelo espaço e como estrutura dinâmica multidimensional.

\begin{abstract}
Ao abandonar o balé, Forsythe abre um espaço de memória que o mantém muito mais vivo em seu próprio ato de desaparecimento. Ao reorganizar o espaço, o som, a luz, o corpo e seus movimentos, os balés de Forsythe tornam-se textos que se recusam a ceder a um objeto, um artefato, a favor de um efeito de arte melancólica. Eles fazem uso da perda original de um pequeno detalhe que não dão ao assunto do balé o que ele quer, mas sim desestabiliza-o na própria lembrança de alguma coisa que não pode ser lembrada. (SIEGMUND, 2011:129, tradução nossa) ${ }^{55}$
\end{abstract}

O desaparecimento das disposições espaciais que conhecemos gera tensões nas quais o público, ao tentar acessar aquilo que já conhece, percorre trajetos desconhecidos. O balé desaparece ao mesmo tempo em que gera campos perceptivos nos quais novas possibilidades de observação desafiam o olhar e a memória do espectador. Aquilo que era balé, aquilo que

\footnotetext{
${ }^{54}$ Texto original: "Working with classically trained dancers, he has reinvented ways of articulating balletic principles by ignoring the logic that governs the order and impulses of steps, so that any part of the body can determine momentum and direction, and any kind od moviment can coexist alongside and be integrated into a classical vocabulary." ${ }^{54}$ (Kinetic Isometries. Roslyn Sulca)

${ }^{55}$ Texto original: "While abolishing ballet, Forsythe opens up a space of memory for ballet that keeps it very much alive in the very act of disappearance. By reorganising space, sound, light, the body, and its moviments, Forsythe's ballets become texts that refuse to yield an object, an artefact, in favour of a melancholy art effect. They make use of an original loss of small detail that does not give the subject of ballet what it wants, but rather destabilises it in the very act os remembrance of something that cannot be remembered." (Siegmund, 2011:129)
} 
era imagem nítida de uma ordem se desfaz diante da produção de novas passagens para o corpo e para o olhar.

No texto "Um americano na Europa: Balé para o século XXI",56 Gerald Sigmund afirma que por detrás da prática não convencional de Forsythe existe sempre um processo complexo de reflexão sobre a dança e sobre o balé, especialmente. Deste modo, o balé e sua história são temas de grande importância no trabalho de Forsythe. Para Forsythe, o palco é um campo experimental de investigação onde, através da disponibilidade dos artistas, é possível transformar a percepção do que o balé e a dança são ou podem ser.

William Forsythe (2014) afirma ainda que: "Ninguém nunca participa de uma grande conversa dizendo a mesma coisa repetidas vezes", ele diz. "Você precisa ver o que é possível." ${ }^{57}$ Com essa afirmação ele faz uma analogia às transformações que imprime ao balé e também à dança. $\mathrm{O}$ intuito de experimentar novos pontos de observação e orientações para as suas práticas reverberam em propostas que aproximam seus trabalhos de princípios e fundamentos abordados pela filosofia ao mesmo tempo em que evidenciam problemáticas basilares da arte contemporânea, como o entrelaçamentos de linguagens e a investigação da arte como um amplo campo investigativo e de produção de conhecimento.

Questionado sobre o balé moderno como um novo caminho possível de formação em dança, ele rebate:

\begin{abstract}
<Balé moderno> é uma falso conceito. Não há um balé moderno. O balé consiste em $\mathrm{A}, \mathrm{B}, \mathrm{C}$ e assim por diante, uma série de relações. Eu prefiro dizer que existe <balé puro>, que são as ideias de orientação no espaço, as quais constituem esta forma de arte, e existe o balé clássico, que é uma sintaxe muito específica destes elementos, destas orientações. Há aqui um grande mal-entendido. O balé clássico é uma forma de balé, é uma forma de pensamento sobre os corpos no espaço, não mais do que isso. $\mathrm{E}$ os movimentos são supostamente métodos realizáveis de $\mathrm{A}$ à $\mathrm{B}$. Isto é balé clássico, como sempre foi feito, de A a B. Hoje é possível ir de A a R, e isso é ainda balé. Se trata aqui de uma sintaxe lógica. (William Forsythe em "Tanz und Sprache", 1993:16, tradução nossa). ${ }^{58}$
\end{abstract}

\footnotetext{
${ }^{56}$ Texto disponível no livro "Denken in Bewegung", de 2004, com organização de Gerald Siegmund.

${ }^{57}$ Citação extraída da matéria de Sarah Crompton. Elevated visions: "how William Forsythe changed the face of dance”. Disponível no link: http://www.theguardian.com/stage/2015/mar/07/in-the-middle-somewhat-elevatedwilliam-forsythe-dance. Acesso em 18.05.2014. Texto original: "No one ever participated in the big conversation by saying the same thing over and over again," he says. "You have to see what is possible."

${ }^{58}$ Texto original: "Modernes Ballett ist ein falscher Begriff. Es gibt kein modernes Ballett. Das Ballett besteht aus A, B, C usw., eine Folge von Beziehungen. Ich würde lieber sagen, es gibt ( reines Ballet) das sind die Idee zur Orientierung im Raum, die machen diese Kunstform aus, uns es gibt klassisches Ballet, das ist eine ganz bestimmte Syntaz dieser Element, dieser Orientierungen. Hier kommt es zu großen Mißverständnis. Das klassisches Ballet ist eine Form dês Balletts, es ist eine Denkform über Körper im Raum, mehr ist ES nicht. Und Bewegungen sind vorgeschlagene Methoden, um von A zu B zu gelanden. Das ist klassiches Ballett, so wurde es immer gemacht, von A bis B. Heute kann man von A bis R gehen, uns das ist immer noch Ballet. Es handelt sich hier um eine logische Syntax.” (Willliam Forsythe em "Tanz und Sprache”, 1993:16).
} 
Esse comentário de Forsythe, de 1993, demonstra um interesse do artista em observar as variações possíveis daquilo que uma forma ou linguagem podem vir a ser. Entretanto, o que vemos hoje em suas falas é muito menos o intuito de experimentar possibilidades para o balé e muito mais a disposição em buscar alternativas para o corpo, para o espaço e para a percepção sem que uma categoria ou referencial seja mantido.

O balé clássico em suas orientações espaciais é uma partitura, um sistema de representação que auxilia na produção de movimentos e interações espaciais. Forsythe faz uso desses referenciais para explorar trajetos e possibilidades para o movimento. Pontos e linhas se movem e incentivam a construção de novos vetores para o pensamento do corpo no espaço. A investigação do corpo em órbitas pelo espaço a partir de referenciais do balé logo se transformou em uma compilação e em um cruzamento de referenciais que ampliaram o repertório de pesquisa de Forsythe. Os recursos e as abordagens se multiplicaram de tal modo que suas práticas logo atravessaram a estabilidade de áreas, de categorias e de classificações. À prática do balé se somam às mais variadas orientações e perspectivas espaciais.

\section{O sistema Laban}

O sistema de notação de Rudolf Laban (1879-1958) é um método de análise e estudo do movimento "onde o corpo é visto como parte de uma relação estrutural em movimento, que inclui Corpo, Esforço, Forma e Espaço, categorias interrelacionadas que se informam mútua e continuamente." (Miranda, 2002:17).

Uma das principais referências de Laban, a figura do Icosaedro, é composta por vinte faces triangulares unidas por doze vértices e é também "o sólido geométrico regular que mais se aproxima do volume de espaço que circunda tridimensionalmente o corpo"( Maria Cecília P. Laçava, 2006:168). Essa formação espacial, que permite a observação de ângulos e alinhamentos do corpo a partir de diferentes perspectivas foi denominada, por Laban, como Kinesfera. A kinesfera adota como referencial o centro do corpo e é delimitada pela extensão máxima das pernas e dos braços. A partir do centro do corpo tem-se então seis direções, assim estabelecidas pela Kinesfera: em cima, abaixo, direita, esquerda, atrás e em frente. Essas direções, por sua vez, geram ações como descer, subir, cruzar, abrir, recuar e avançar. Essas indicações levam ainda em consideração qualidades, como o esforço, que aparecem nas dinâmicas dos movimentos.

Em Laban, a zona de ação do corpo se expande, ganha profundidade, amplitude e 
surgem novos alinhamentos e incursões espaciais.

Se no balé clássico os movimentos tendem a posições fixas que priorizam o plano frontal e a estabilização de padrões e posições para os movimentos, em Laban serão ressaltados aspectos que enfatizam a descoberta de orientações que ampliam as possibilidades do corpo no espaço.
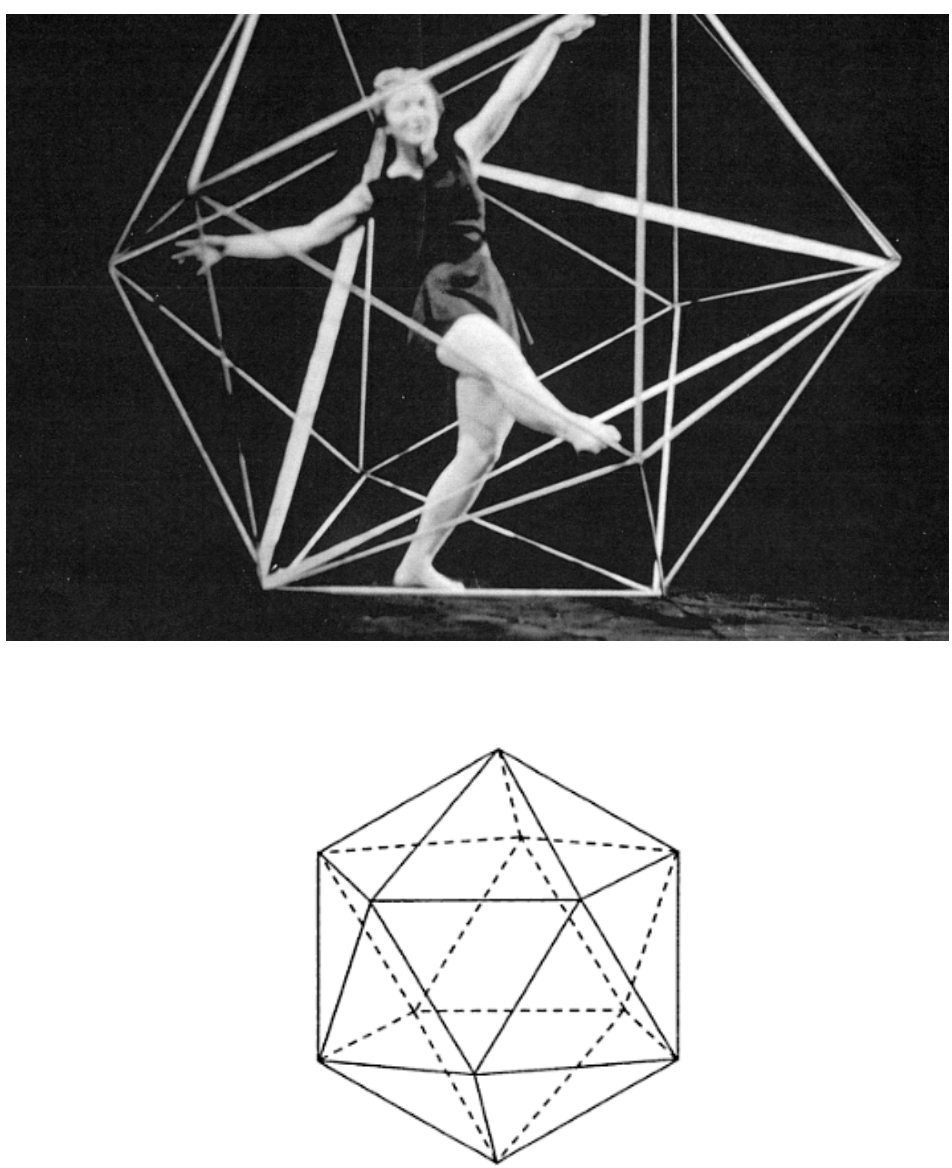

Embora a figura do icosaedro, proposta por Laban, estivesse ainda amparada em uma abordagem espacial objetiva orientada pela geometria euclidiana, suas propostas previam a observação e o experimento de qualidades e variações que eram até então desconsideradas, se levarmos em conta a dança dentro de um recorte histórico e geográfico ocidental específico no qual estamos, de algum modo, inseridos. As variações previstas pelo estudo do movimento, a partir das contribuições de Laban, confrontavam aspectos subjetivos e objetivos em análises que extrapolaram rigores e postulados científicos na abordagem do corpo e do movimento. Regina Miranda fala sobre esse assunto: 
absoluta, objetiva, científica e capaz de acessar objetivamente o objeto, em abordagens psicanalíticas, que consideravam a subjetividade como fonte de verdade, tentaram fazer a ponte entre abordagens objetivas e subjetivas, pela construção de um sistema complexo que, embora enraizado na geometria euclidiana como representação espacial, já apresentava outras intensidades espaciais e integrava corpo, mente, sensação e tensão espacial pelo movimento. (MIRANDA, 2002:12)

Forsythe estudará o sistema Laban com rigor e encontra na estruturação de volumes geométricos, como o icosaedro, novas orientações para as suas investigações e práticas. É neste contexto, que desenha pontos e linhas pelo espaço, que referenciais do balé clássico, princípios do Sistema de Laban e demais recursos se cruzarão em suas propostas e experimentos.

Sob essa perspectiva de estudo e investigação do movimento, Forsythe lança um programa multimídia, o CD-ROM Improvisation Technologies, de 1999, que foi proposto por Paul Kaiser e criado em parceria com Christian Ziegler, Nik Haffner e Volker Kuchelmeister, no Zentrum für Kunst und Medientechnologie - ZKM (centro de arte e tecnologia de mídia), em Karlsruhe, na Alemanha.

Paul Kaiser ${ }^{59}$ descreve o primeiro encontro com Forsythe e a tentativa do artista de explicar seu procedimento de trabalho:

Eu me encontrei com William Forsythe pela primeira vez em sua cozinha em Frankfurt, em 1994. A primeira coisa que Bill fez foi tentar explicar como ele procede com a criação de novos movimentos. Ele começou a desenhar formas imaginárias no ar, e em seguida, articulava seus membros através desta geometria complexa e invisível. Como um não-dançarino, eu fiquei completamente perdido. ${ }^{60}$

Kaiser $^{61}$ comenta ainda a dificuldade de compreensão daquilo que Forsythe estava sugerindo: "Como um não-dançarino, eu tinha pouca consciência de kinesfera do corpo - o volume total de movimento potencial de um corpo. Mais tarde eu sugeri a Billy que ele usasse animação digital para tornar a sua demonstração visível." ${ }^{62}$

\footnotetext{
${ }^{59}$ Paul Kaiser produziu anteriormente um arquivo multimídia para os trabalhos de Robert Wilson. Informação disponível no material impresso que acompanha o CD-ROM. Página11.

${ }^{60}$ A conversa entre Forsythe and Kaiser foi gravada em 1998 e publicada mais tarde no Performance Research, v4\#2, verão de 1999. Disponível no link: http://openendedgroup.com/writings/danceGeometry.html. Texto original: "I first met William Forsythe in his kitchen in Frankfurt in 1994. The first thing Bill did was to try to explain how he goes about creating new movements. He started drawing imaginary shapes in the air, and then running his limbs through this complicated and invisible geometry. As a non-dancer, I was completely lost."

${ }^{61}$ Texto disponível no material impresso do CD-ROM Improvisation Technologie, P. 11.

${ }^{62}$ Texto original: "As a non-dancer, I had little awareness of the body's kinesphere - the total volume of a body's potential moviment. Later I suggested to Billy that he use computer animation to make his demonstration visible." (Kaiser).
} 
Neste material multimídia, Forsythe, em uma de suas descrições e análise de movimento, sugere que se imagine o corpo como uma série de infinitos pontos e linhas e que qualquer um desses pontos possa se mover pelo módulo, ou pela figura geométrica que ele utiliza para explicar coordenadas espaciais. Na primeira parte de sua explicação ele se concentra na construção de linhas tendo como referencial o modelo ou a orientação geométrica proposta por Laban. Quando as extremidades do corpo, como dedos da mão e dos pés, tocam esse pontos, logo reconhecemos movimentações e posições que podem ser identificadas também no balé clássico. O que ele sugere a partir daí é que se experimente conectar outras partes do corpo, como cotovelos e joelhos, a esses pontos imaginários que compõem a estrutura espacial que envolve o corpo, ou a kinesfera, assim denominada por Laban. De acordo com Forsythe, o que acontece quando diferentes partes do corpo tocam esses pontos é que são criadas novas relações com esse módulo que circunda o corpo. Ao invés de dar prioridade às extremidades, se passa a dar importâncias a todos os pontos e todas as linhas do corpo. As figuras a seguir ilustram os dois momentos relatados por Forsythe e descritos acima:

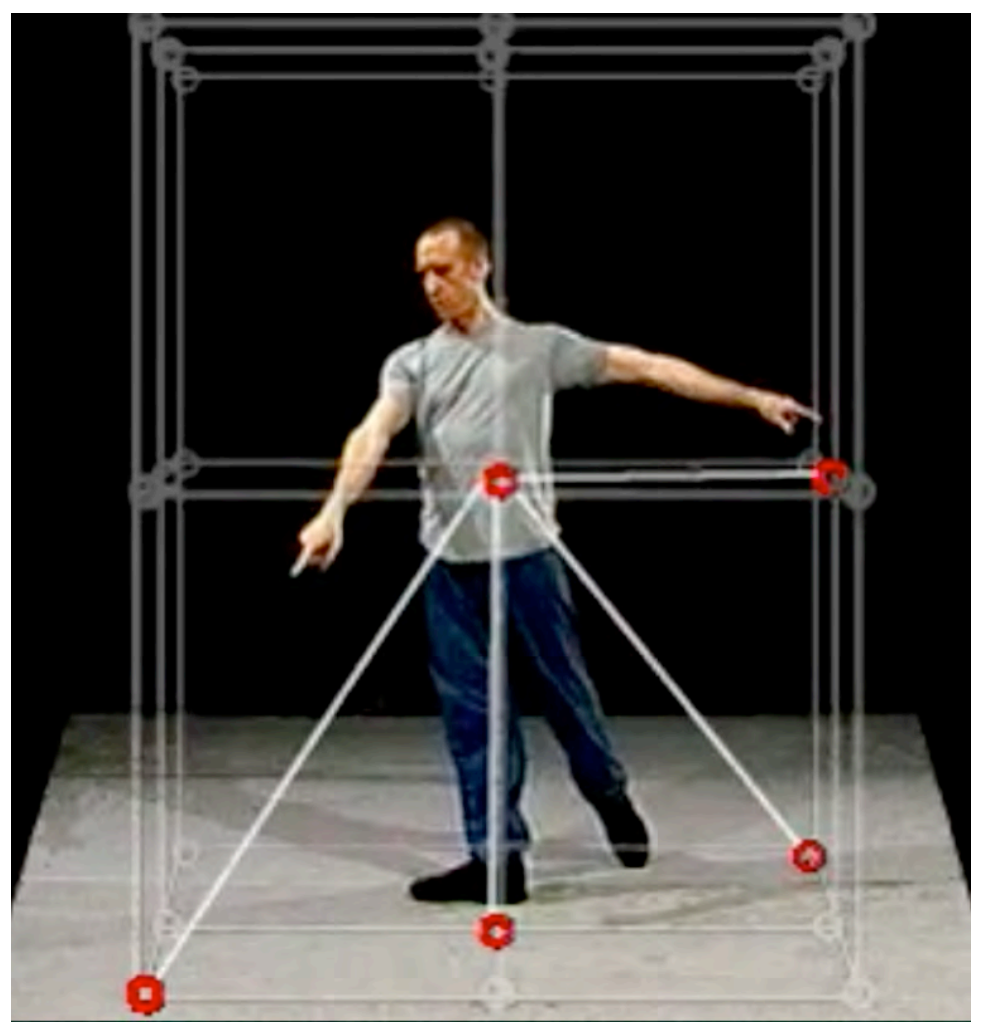




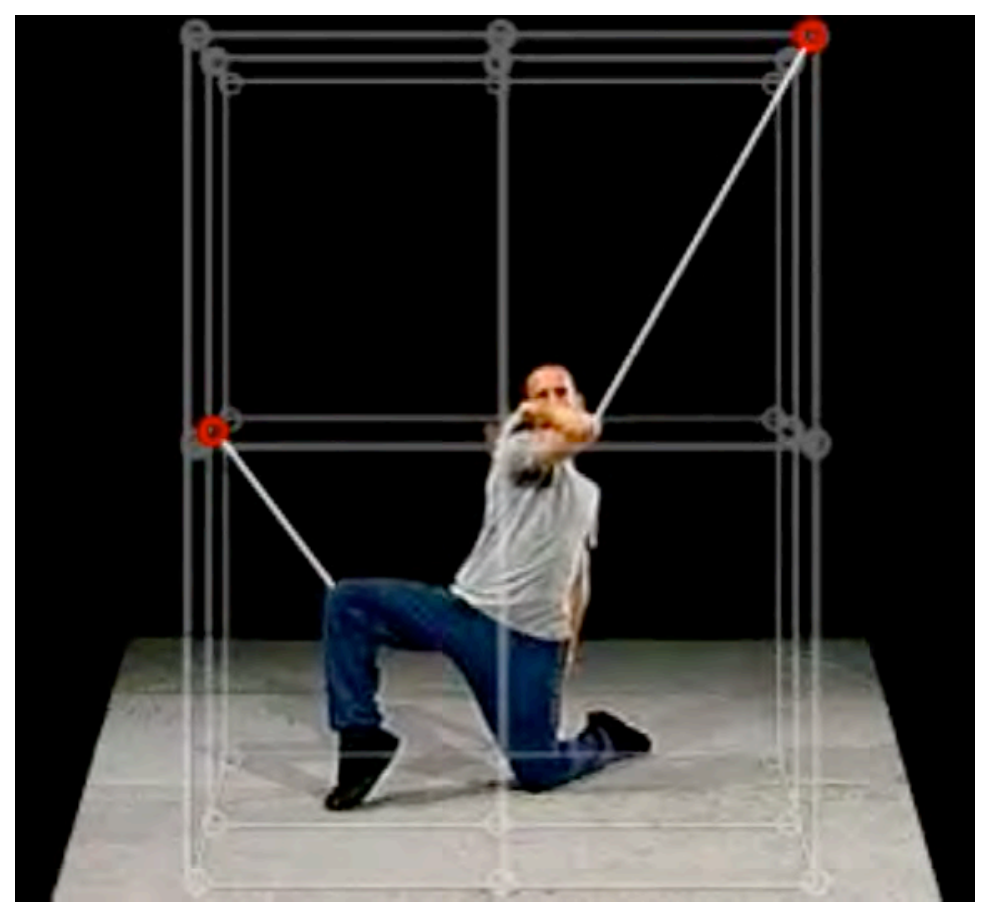

Forsythe imprime novas possibilidades de relação com o entorno ao mesmo tempo em que descentraliza o movimento e transforma a conhecida orientação do centro em direção à periferia, às extremidades, em estruturas policêntricas que dão ênfase a detalhes, curvas e dobras do corpo que interagem com o entorno. Essa descentralização favorece a descoberta de movimentações não usuais e muitas vezes ainda não assimiladas ou experimentadas pelo corpo, já que os movimentos que executamos, no dia-a-dia ou em práticas de arte, tendem a reproduzir padrões já conhecidos. "Se para Laban o centro é colocado no centro do corpo, no plexo, no abdômen, para Forsythe, o centro é colocado ludicamente em qualquer lugar", explica a autora Maria Cecília P. Laçava ${ }^{63}$ (2006 :177).

A estrutura do balé e o sistema de notação de Laban são alguns dos referencias que Forsythe utilizará como fonte para o desenvolvimento de seus métodos e experimentos de estudo. E será com base nessas orientações que Forsythe experimentará rupturas através de procedimentos que destacam a importância de instabilidades e oscilações que agem sobre essas estruturas e mecanismos.

\section{Respiração}

\footnotetext{
${ }^{63}$ Texto de Maria Cecília P. Laçava no livro "Reflexões sobre Laban, o mestre do movimento". Organizadores: Maria Mommensohn e Paulo Petrella. Sao Paulo: Summus, 2006.
} 
Suas orientações espaciais, que dão destaque à instabilidade e às variações, aparecem em vínculos e interações ambientais como aquilo que permite ajustes, atualizações e micro ou macro variações nas formas. Essas oscilações são como canais que favorecem a respiração de estruturas, movimentos e composições. As tomadas de decisão que acontecem nos encontros, nas colisões e nas coalizões entre corpos são fundamentais no surgimento de atualizações e diferenciações que mantém o trabalho vivo e em movimento.

Há no processo investigativo e na trajetória de Forsythe um evento que, embora pouco comentado e discutido por pesquisadores, influenciará fortemente sua perspectiva coreográfica - o contato com o Budo ${ }^{64}$.

A partir de 2005 a The Forsythe Company contará com a presença de Akira Hino, mestre de Budo, que passará a trabalhar com a companhia a partir de princípios associados a energia e a consciência do corpo, que estão presentes no conceito de Ishiki - que pode ser descrito a partir de palavras como consciência, mente, sexto sentido e assim por diante ${ }^{65}$. De acordo com Freya Vass-Rhee:

(...) o grupo também tem investigado pelo menos um modo de percepção que está fora das categorias ocidentais comuns de "perceber". Desde 2005 que a The Forsythe Company tem recebido regularmente Akira Hino, um professor mestre de Budo que trabalha com a companhia propondo a ativação do Ishiki do corpo - um conceito de difícil tradução, mas que está associado à energia, à consciência, ou à mente - e desenvolvendo a capacidade de "perceber" e de se conectar com o Ishiki de outros. A colaboração do Hino-Sensei afetou profundamente a dramaturgia e a coreografia do trabalho Three Atmospheric Studies, que estreou em 2005 e que sofreu alterações na temporada seguinte.(VASS-RHEE, 2011:155, tradução nossa) ${ }^{66}$.

Mesmo que a percepção, a consciência e a sensibilidade dos bailarinos tenham sido qualidades e condições solicitadas desde as primeiras propostas de improvisação de Forsythe, a atenção e a abertura para o entorno parecem ganhar ainda mais destaque em suas investigações a partir do contato com o Budo.

\footnotetext{
${ }^{64}$ Budo significa arte marcial janopesa. São as artes marciais japoneses modernas.

${ }^{65}$ Descrição feita por Yoko Ando, integrante da The Forsythe Company. O relato completo e descrição do trabalho de Hino-Sansei pode ser encontrado em: http://art-budo.hino-budo.com/art-budo/Contact-betweenBudo-and-dance.htm. (Acesso em 20 de setembro de 2015)

${ }^{66}$ Informação disponível na tese de doutorado "Audio-Visual Stress: Cognitive Approaches to the Perceptual Performativity of William Forsythe and Ensemble”, de Freya Vass-Rhee, de 2011. Texto original: “(...) the ensemble has also investigated at least one mode of perception that falls outside of common Western categories of sensing. Since 2005, The Forsythe Company has regularly hosted Akira Hino, a master teacher of budo who works with the company on sensing the body's ishiki - a concept which defies translation but which is associated with energy, consciousness, or mind - and developing the ability to sense and connect with the ishiki of others. The collaboration with Hino-Sensei profoundly affected the dramaturgy and choreography of the work Three Atmospheric Studies, which was premiered in 2005 and further developed over the following season. (Freya, 2011:155)"
} 
Em entrevista, Forsythe pontua a importância da atenção, qualidade que passou a ser enfatizada em seus trabalhos a partir do contato com Akira Hino. O trabalho com o mestre japonês influenciou significativamente a montagem de Três Atmosférica Studio, e principalmente a primeira parte deste trabalho, Clous afetar Cranach. Forsythe comenta:

\begin{abstract}
Nós estamos interessados em apenas uma coisa, que é basicamente a qualidade da atenção. Então, os artistas têm apenas uma diretiva real ... no caso desta situação preste atenção na outra pessoa. Isso é tudo o que eles têm que fazer. Mas o maior trabalho deles é focar a atenção ... ver as coisas de forma diferente. Então, eu estou interessado na natureza da atenção e da atenção coletiva, e como parte disso, mais do que outra coisa, é aquilo que nós tentamos sintonizar. (William Forsythe em Vass-Rhee, 2011:156, tradução nossa) ${ }^{67}$
\end{abstract}

A atenção aparece, nas propostas de Forsythe, como elemento, qualidade ou ponto que abre o trabalho para conexões com o entorno, com o ambiente. A atenção aparece como concentração difusa, como percepção atenta aos pontos, linhas, dobras, esquinas e superfícies em variados pontos do ambiente. A percepção varre o espaço, toca corpos, paredes, atravessa janelas, frestas e respirações. Uma constelação de movimentos e interações se manifesta nesse espaço plural e intenso que respira em qualidades, tons e variações.

Respiração é troca imediata, é incursão do corpo pelo espaço e do espaço pelo corpo. É a diluição do corpo em espaço e vice-versa. A respiração é o estiramento de linhas que se sobrepõem, que se cruzam, que se torcem e geram as mais variadas relações e desenhos espaciais. E esse será um dos aspectos que criará uma perspectiva ambiental ao trabalho Three Atmospheric Studie. Neste trabalho, o pulso ou o ritmo entre os corpos gera dinâmicas coreográficas particulares.

O trabalho Three Atmospheric Studies, que estreou em 2005, evidencia importantes mudanças na abordagem coreográfica de Forsythe. Esse trabalho, de acordo com Roslyn Sulcas, marca o desenvolvimento de um novo tipo de estrutura coreográfica. Essa nova estrutura é descrita pela autora como "fugal organization” ou organização em fuga. Forsythe fala ainda sobre a ideia de "fuga" como algo que ele não havia usado antes ${ }^{68}$.

Essa estrutura baseada na indicação de "fuga" prevê o choque entre movimentos e o

\footnotetext{
${ }^{67}$ Em entrevista de Forsythe "William Forsythe, Michael Klein, and Steve Valk, post-performance discussion, Dublin, April 18, 2008" disponível na tese "Audio-Visual Stress: Cognitive Approaches to the Perceptual Performativity of William Forsythe and Ensemble", de Freya Vass-Rhee, de 2011. Texto original: "We're only interested in one thing, which is basically the quality of attention. So the performers only have one real directive...and that's to stay in the situation - pay attention to the other person. That's all they have to do. But their larger job is to focus your attention... You see things differently. So I'm interested in the nature of attention and of collective attention, and that part of it, more than anything, is what we try to tune."

${ }^{68}$ Informação disponível no material impresso que acompanha o CD-ROM Improvisation Technologies. P.40.
} 
surgimento de trajetos e qualidades não previstas. A sequência de movimentos é feita, e após a indicação de Forsythe esta frase deve ser executada, por uma parte dos dançarinos, de trás para frente enquanto a outra parte do grupo continua com a movimentação - o que altera toda a estrutura do conjunto. Novas relações e pontos de contato surgem desses acasos, encontros e ângulos entre os corpos. Sulcas comenta esta prática:

primeiramente, cada grupo executa a frase de forma simples; em seguida a executa de trás para frente. Mas, enquanto um grupo começa a inverter a frase no meio e o outro segue com a movimentação, Forsythe diz: "relações inteiramente novas, novos pontos de interconexão entre os dançarinos". (Sulcas, 2011:17, tradução nossa) ${ }^{69}$

Three Atmospheric Studies, considerado por alguns críticos, como a "Guarnica de Forsythe" foi inspirado em uma pintura do renascentista alemão Cranach e aborda a guerra do Iraque. A primeira parte do trabalho, na qual destaco as qualidades e observações aqui apresentadas, inicia com uma mulher anunciando que seu filho foi preso, como na cena abaixo:

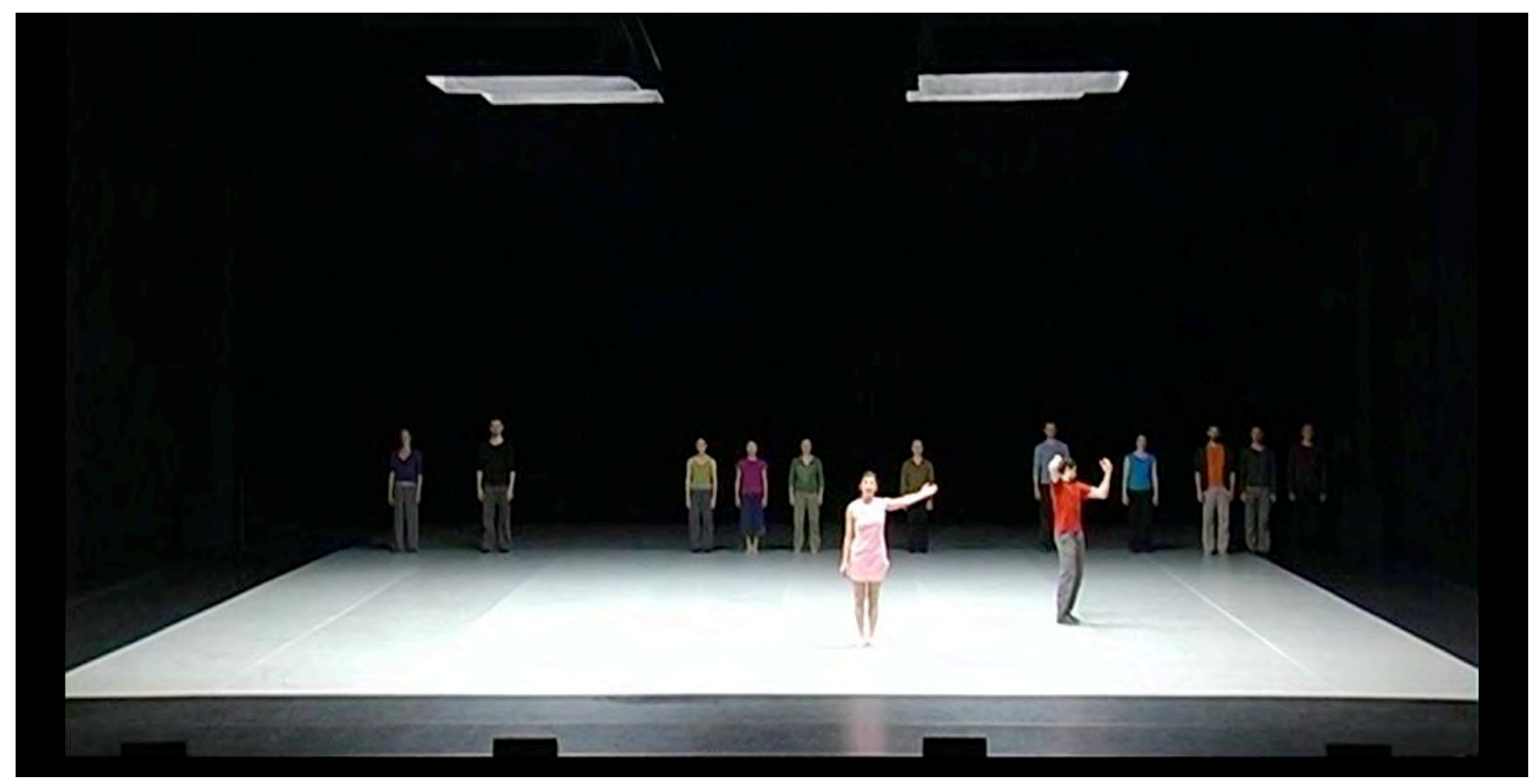

Three Atmospheric Studies

Roslyn Sulcas (2011:16) ressalta ainda que é com esse trabalho que Forsythe alcança, de modo mais sofisticado, a ideia de "breath score" $" 70$ - movimento sincronizado através da respiração. Forsythe, em entrevista a Sulcas, por telefone, comenta:

\footnotetext{
${ }^{69}$ at first each group does the phrase in straightforward fashion; then performs it backwards. But as one group begins to reverse the phrase at midpoint while the other keeps going you get, Forsythe says, "entirely new relationships, new points of interconnectedness between the dancers. Roslyn Sulcas, 2011

${ }^{70}$ De acordo com Roslyn Sulcas (2011:16), a ideia de "breath score" surgiu em Duo e mais tarde em N.N.N.N e The Room as it Was.
} 
Os dançarinos são inerentemente musicais por causa da natureza do movimento, e esta é uma extensão da ideia de sua autonomia musical. Three Atmospheric Studies é ensaiado como uma peça de música. Todo mundo ouve a respiração coletiva, e a dificuldade de aprendizado não está nos passos, mas em aprender a sincronizar a sua respiração com a do grupo. É como "desenhar a respiração", em ambos os sentidos da frase. (William Forsythe em entrevista por telefone, 27 de abril de 2010 a Sulcas, 2011:16, tradução nossa) $)^{71}$
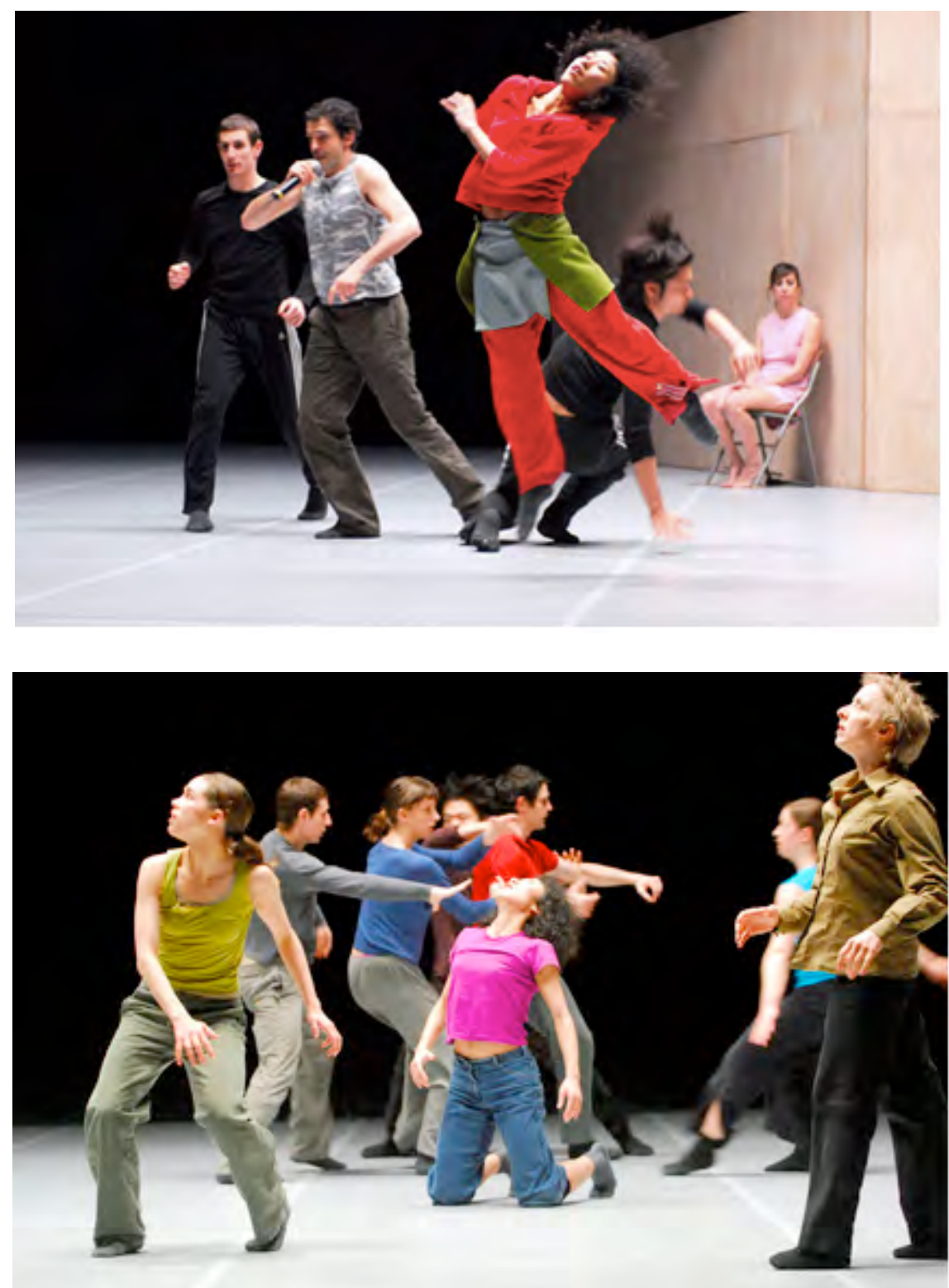

Three Atmospheric Studies

A percepção ou o sensível são habilidades ou aberturas solicitadas nos procedimentos

\footnotetext{
${ }^{71}$ Texto original: "Dancers are inherently musical because of the nature of moviment, and this is an extension of the idea of their musical autonomy. Three Atmospheric Studies is rehearsed like a piece of music. Everyone listens to the colective breathing, and the difficulty of learning it is not in the steps but in learning to synchronize your breathing with the group. It's like "drawing breath", in both senses of the phrase." (William Forsythe. Entrevista de Sulcas por telefone, 27 de abril de 2010 - Sulcas, 2011:16)
} 
de Forsythe que geram variações e atualizações constantes da forma. Respirações e encontros possibilitam atravessamentos e fazem oscilar as linhas que vemos surgir entre os corpos e o espaço. Vass-Rhee fala sobre a percepção, a atenção e a sensibilidade nos trabalhos da The Forsythe Company:

\begin{abstract}
As modalidades de improvisação de Forsythe baseadas na percepção exigem de seus intérpretes um competência perceptiva aprimorada - maior consciência da sensibilidade, habilidades dos órgãos dos sentidos e um envolvimento intenso e afinado com possibilidades sensoriais reais e imaginárias. Através de modalidades que exigem uma atenção intensa e constante, muitas vezes através de múltiplos meios sensoriais, as habilidades de percepção dos artistas são refinadas e ampliadas muitas vezes da mesma maneira que o movimento é aprimorado através de técnicas de dança. Como resultado desses processos, a "performance da percepção" dos dançarinos é otimizada e diversificada. Idealmente, para Forsythe, ela se torna uma faceta central da performance, aquela que, por sua vez, aumenta e orienta a atenção do público. (VASS-RHEE, 2011:156, tradução nossa) ${ }^{72}$
\end{abstract}

O foco nas habilidades perceptuais dos dançarinos gera um campo de atenção que se expande para a plateia. Aquilo que observamos no palco ganha intensidade e estimula o olhar do espectador para detalhes e entonações que aparecem em detalhes e em mecanismos que estimulam experiências orientadas pelos sentidos. Essas considerações coincidem com fundamentos encontrados na noção de teatro pós-dramático de Hans Thies Lehmann e são assim comentadas por Vass-Rhee:

\begin{abstract}
Em suma, eu enfatizo que a prática do teatro pós-dramático coloca em primeiro plano não só o físico, como também os limites cognitivos dos artistas, especialmente quando modalidades coreográficas são baseadas na experiência perceptiva. A prática de improvisação solicita uma intensificação da atenção dos artistas (...). Esta atenção intensificada, que se torna um assunto central no contexto pós-dramático, aumenta a atenção do público (...). (VASS-RHEE, 2011:158, tradução nossa) ${ }^{73}$
\end{abstract}

As propostas de Forsythe que serão mencionadas no texto a seguir abordam a arte como estímulo para desvios, para reorganizações que incentivam discussões sobre mecanismos que

\footnotetext{
${ }^{72}$ Texto original: "Forsythe's perception-based improvisation modalities thus require of their performers an enhanced perceptual expertise - increased awareness of the sensitivity and full range of abilities of the sense organs and heightened, honed engagements with both real and imaginary sensory possibilities. Through modalities which demand intensified and sustained attention, often across multiple sensory modes, the perceptual abilities of the performers are refined and expanded in much the same way that movement is refined in dance techniques. As a result of these processes, the dancers' performance of perception is optimized and diversified. Ideally, for Forsythe, it becomes a central facet of performance, one that in turn heightens and focuses audience attention." (Vass-Rhee, 2011:156)

${ }^{73}$ Texto original: "In sum, I emphasize that postdramatic theatre practice foregrounds not only the physical but also the cognitive limits of performers, particularly when choreographic modalities are based on perceptual experience. Improvisational practice evokes a heightening of performer attention (...). This intensified attention, which becomes a central subject in postdramatic presentation, heightens and focuses audience attention (...). (Vass-Rhee, 2011:158)
} 
padronizam ou desestabilizam o olhar.

Esse processo, que analisa e explora movimentos, sugere rotas e translados espaciais a partir de linhas que se expandem para além de sequências ou organizações que se concentram no corpo como unidade desvinculada de aspectos ambientais. O ambiente pulsa e passa a compor quadros abertos, estruturas dinâmicas que se formam e favorecem variações nas interações entre corpo e espaço. Espaço e corpo, aliás, surgem como instâncias, como manifestações de condições que sobrepõem aspectos materiais e subjetivos no deslocamento de corpos em diferentes configurações espaciais.

Tudo isso irá gerar novas linhas para o pensamento e a prática da coreografia. Linhas se cruzam e vinculam o corpo ao espaço ao mesmo tempo em que geram uma noção móvel para o conceito de coreografia. A coreografia se manifesta como desenho de linhas que aparecem e somem. Quando as linhas começam a se mover e a interagir entre si e com os demais elementos e estímulos do ambiente surgem inesperadas possibilidades de aproximações e abordagem filosóficas dos eventos.

E é deste modo que eu apresento algumas indicações, passagens e características que jogam o termo coreografia para contextos distantes daqueles associados aos passos e às estruturas fixas que tendem a ser vinculadas à ideia da dança. A respiração, a atenção e a relação ou as negociações sugeridas por Forsythe dão aos trabalhos uma perspectiva coreográfica dinâmica e transversal que pode ser constatada em diferentes propostas, procedimentos e contextos. Impactos físicos e possibilidades de abertura para o entorno são indicações que ampliam a sua compreensão da noção de coreografia. 


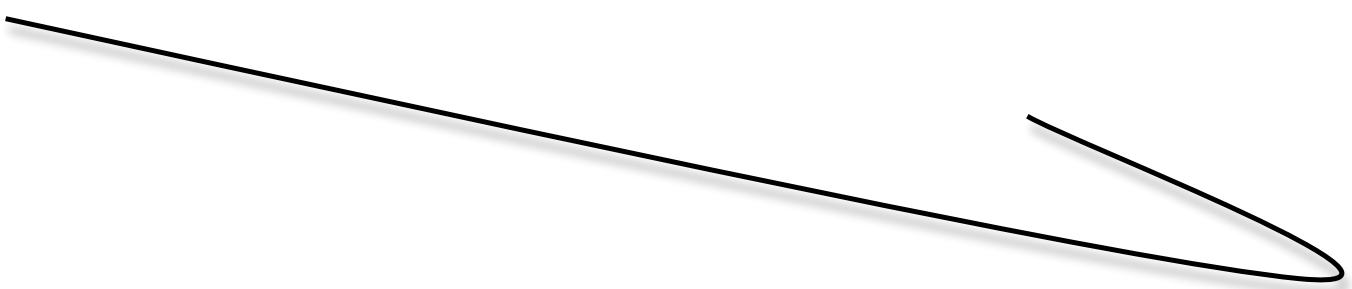

Ponto

Linha Linha Linha Linha Linha Linha Linha Linha Linha Linha Linha Linha

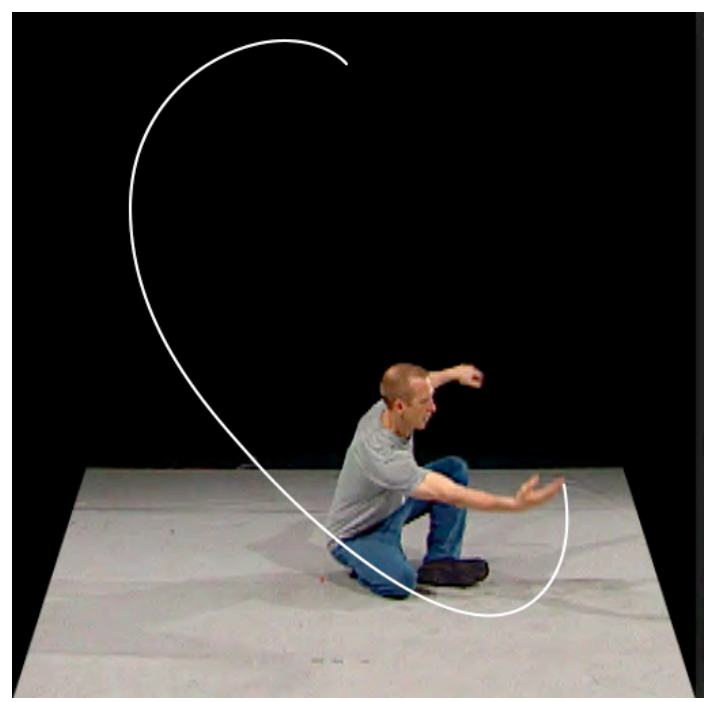

Com essa descrição William Forsythe nos apresenta o ponto de partida das noções e conceitos que virão a seguir. 


\section{Estruturas $V A Z A D A S$}

$\mathrm{O}$

que

está

vazado

deixa

escorrer. Frestas são respiros do pensamento. O que eu vejo pelos intervalos são pausas agitadas que desviam meu olhar.

Os

olhos

atravessam

a

forma,

se infiltram entre linhas e pontos, furam as lógicas estáticas e experimentam a invasão de uma infinidade de forças, vetores, massas e sonoridades desconhecidas. Tempos e espaços são incursões, passos que mergulham em vazios, respirações que alteram velocidades, paisagens quebradiças, contrastes entre a leveza da neve caindo e o ar extremamente gelado/a temperatura extremamente baixa que fisga o corpo e provoca cortes na pele. Estruturas vazadas são espaços inconstantes, paralelos e misturados aos tons que compõem as camadas de tintas que esboçam estações.

Estruturas vazadas são silêncios que sopram sonoridades e mudam as coisas de lugar. 


\section{Desenhar o espaço}

Michel Foucault no texto "De outros Espaços",74, publicado em 1984, lança uma perspectiva de análise do nosso tempo e do modo como criamos relações a partir de uma abordagem espacial que dá ênfase à interação entre diferentes elementos, estímulos e subjetividades. O espaço é uma justaposição de lugares, é uma névoa que atravessa limites e a produção de pensamentos que agem como forças em diferentes direções. Foucault (1984) comenta: "A nossa época talvez seja, acima de tudo, a época do espaço. Nós vivemos na época da simultaneidade: nós vivemos na época da justaposição, do próximo e do longínquo, do lado-a-lado e do disperso." O filósofo destaca a importância do espaço e analisa o modo como a realidade e as relações com o tempo e com a história são construídas. Abordar a história e o tempo a partir de uma perspectiva que agrupa elementos semelhantes e desconsiderar as variações e as diferenças que se manifestam em todo o evento diz respeito a um empenho em produzir configurações determinadas, lugares com usos e funções específicos. Esses princípios, comuns no contexto do estruturalismo, são vistos por Foucault (1984) do seguinte modo: "Na verdade, o estruturalismo não implica uma negação do tempo; mas acarreta uma certa maneira de lidar com aquilo a que chamamos tempo e com aquilo a que chamamos história." Associar episódios com recortes objetivos de tempo ou período é desconsiderar aspectos e complexidades que se manifestam na experiência de um tempo não linear e subjetivo. É assujeitar acontecimentos a perspectivas fixas e estáveis que fragmentam e manipulam o tempo e a história. É ignorar as mais variadas condições e experiências que se entrelaçam e se apresentam em processos e acontecimentos históricos.

Enquanto o século XIX é marcado por uma certa obsessão pela história, Foucault (1984) fala sobre o espaço e o tempo no século XX: "acredito que a ansiedade da nossa época tem a ver fundamentalmente com o espaço, muito mais do que com o tempo. O tempo aparece-nos como apenas uma das várias operações distributivas que são possíveis entre os elementos que estão espalhados pelo espaço."

Foucault faz ainda um mapeamento sobre a experiência do espaço no ocidente a partir do período histórico medieval. De acordo com o autor, na Idade Média existia um conjunto

\footnotetext{
${ }^{74}$ Traduzido (com base no texto publicado em Diacritics; 16-1, Primavera de 1986) por Pedro Moura. Conferência proferida por Michel Foucault no Cercle d'E'tudes Architecturales, em 14 de março de 1967. Texto disponível no link: http://www.historiacultural.mpbnet.com.br/pos-modernismo/Foucault-De_Outros_Espacos.pdf Acesso em maio de 2013.

Ou no link: http://www.scielo.br/scielo.php?pid=S0103-40142013000300008\&script=sci_arttext O texto "De outros Espaços" foi apresentado inicialmente em um programa de rádio e se transformou, em 1967, em uma aula que seria publicada posteriormente no ano da morte de Foucault, em 1984.
} 
hierárquico de lugares. Havia lugares associados diretamente à vida cotidiana das pessoas e que coincidiam com as dicotomias entre lugar sagrado e lugar profano, lugar protegido e lugar exposto e lugar rural e lugar urbano, por exemplo, e os lugares nos quais certas coisas eram colocados por terem sido deslocadas dos lugares estabelecidos. Deste modo bastante simplificado é possível perceber que essa hierarquia pautada na oposição de lugares formou o espaço medieval, um espaço no qual as coisas eram dispostas e pertenciam a lugares específicos. Foucault pontua ainda que a transformação do lugar da disposição para o da extensão se dá com Galileu, que abre o espaço ao criar a ideia de infinito.

\begin{abstract}
Este espaço de disposição de fixidez, foi aberto por Galileu. O escândalo profundo suscitado pelas suas investigações não foi o fato de ter descoberto, ou melhor, redescoberto que a Terra girava à volta do Sol, mas na constituição do conceito de infinito e, o que é implícito, de um espaço infinitamente aberto. Num espaço desses, os lugares da Idade Média acabam por se dissolver; um lugar de uma coisa não passava afinal de apenas um ponto do seu movimento, assim como a estabilidade dessa coisa não passava afinal da infinita desaceleração do seu movimento. Por outras palavras, Galileu e todo o século dezessete foram os primeiros de todo um movimento que substituiu a localização pela extensão. (FOUCAULT, 1984: Outros Espaços.)
\end{abstract}

Há então uma substituição da localização pela extensão e posteriormente esse espaço extenso dará lugar ao sítio, que se define pela relação de proximidade entre certos elementos, como o sítio de relaxe temporário - como cafés, cinemas e praias - sítio de transportes - como ruas e ônibus - e sítios semi-fechados ou fechados de descanso - como a casa, o quarto e a cama. Em nossa época os sítios se tornaram uma forma de relação entre vários sítios.

\footnotetext{
Agora, apesar de toda a técnica desenvolvida de apropriação do espaço, apesar de toda uma rede de relações entre saberes que nos ajuda a delimitá-lo ou formalizá-lo, o espaço contemporâneo não foi ainda totalmente dessacralizado (pelo que parece, uma atitude aparentemente diferente da que foi tomada perante o tempo, arrancado da esfera do sagrado no século dezenove). Na verdade, uma certa dessacralização do espaço ocorreu (sublinhada pela obra de Galileu), mas ainda não atingimos o ponto óptimo dessa dessacralização. A nossa vida ainda se regra por certas dicotomias inultrapassáveis, invioláveis, dicotomias as quais as nossas instituições ainda não tiveram coragem de dissipar. Estas dicotomias são oposições que tomamos como dadas à partida: por exemplo, entre espaço público e espaço privado, entre espaço familiar e espaço social, entre espaço cultural e espaço útil, entre espaço de lazer e espaço de trabalho. Todas estas oposições se mantêm devido à presença oculta do sagrado. (FOUCAULT,1984)
}

E há ainda, de acordo com Foucault, os sítios que mais interessam ao autor, aqueles que se relacionam com todos os outros sítios. Esses sítios, lugares ou espaços surgem na superação de dicotomias e levam em consideração experiências e interações entre qualidades subjetivas, objetivas e dinâmicas. 
Esses sítios ou lugares que se relacionam com todos os demais e que desarticulam padrões e alteram relações estabelecidas aparecem nas noções de utopia - espaços sem lugares reais - e heterotopia - espaços reais que se manifestam dentro de toda sociedade. Foucault (1984) diz que heterotopias "são espaços que se encadeiam uns nos outros, mas entretanto contradizem todos os outros."

Foucault discorre ainda sobre a noção de heterotopia: "A heterotopia consegue sobrepor, num só espaço real, vários espaços, vários sítios que por si só seriam incompatíveis." Esse mecanismo de sobreposição leva em consideração aspectos que não se restringem a funções, ordens e disciplinas.

A palavra heteropotia pode ser divida em duas outras: o sufixo hetero, que tem origem do grego e significa diferente, e topia, lugar. A noção de Heterotopia colocada por Foucault trata de aspectos espaciais que levam em consideração contrastes e a existência de espaços que se sobrepõem, se misturam e dissipam aspectos e barreiras dicotômicas. Um exemplo de heterotopia seria a relação que estabelecemos quando nos olhamos no espelho.

(...) transforma este lugar, o que ocupo no momento em que me vejo no espelho, num espaço a um só tempo absolutamente real, associado a todo o espaço que o circunda, e absolutamente irreal, uma vez que para nos apercebermos desse espaço real, tem de se atravessar esse ponto virtual que está do lado de lá. (FOUCAULT,1984)

As considerações de Foucault sobre a noção de heterotopia prevêem uma abordagem menos estruturalista e mais fenomenológica na análise e experiência de eventos. Sobre aspectos da fenomenologia, o autor comenta:

A obra monumental de Bachelard e as descrições dos fenomenologistas demonstraram-nos que não habitamos um espaço homogêneo e vazio mas, bem pelo contrário, um espaço que está totalmente imerso em quantidades e que é ao mesmo tempo fantasmático. (FOUCAULT, 1984)

Esse espaço fenomelógico, composto por qualidades, temporalidades e que permite rupturas com os tempos e as regras espaciais cotidianas, são lugares porosos, áreas em expansão.

As colocações de Foucault auxiliam na observação de condições que superam as demarcações, usos e funções que regulam experiências espaciais e temporais. A noção de heterotopia, como conceito que sobrepõe lugares, espaços reais e imaginários, objetivos e virtuais e gera espacialidades avança para além de considerações sobre formações sociais e prevê o espaço como dinâmica que age entre corpos, coisas, elementos, partículas, imagens, 
formas, respirações e vibrações.

Henri Lefebvre (1991) também analisa o espaço:

\begin{abstract}
Não muitos anos atrás, a palavra "espaço" tinha um significado estritamente geométrico: a idéia evocada era simplesmente a de uma área vazia. $\mathrm{O}$ uso acadêmico era geralmente acompanhado de algum epíteto como "euclidiano", "isotrópico", ou "infinito", e a sensação geral era a de que o conceito de espaço acabou por ser matemático. (LEFEBVRE, 1991:1, tradução nossa) ${ }^{75}$
\end{abstract}

Lefebvre (1991) propõe uma abordagem espacial na qual qualquer tentativa ou estratégia de categorização não passa de uma tentativa de simplificação para conceitualizar e representar o espaço. As definições generalizam, separaram e geram esferas de conhecimento que atuam em campos distintos. Os referenciais não se cruzam. Pressupostos pautados em lógicas dualistas e discriminativas entendem espaços físicos e mentais como domínios distintos.

O pressuposto quase-lógico de uma identidade entre espaço mental (o espaço dos filósofos e epistemologistas) e espaço real cria um abismo entre a esfera mental de um lado e a esfera física e social do outro. (LEFEBVRE, 1991: 6, tradução nossa) ${ }^{76}$

O que entra em jogo na análise e crítica apresentada por Lefebvre é a observação do espaço por uma via que diverge da descrição espacial e que leva em consideração uma multiplicidade de condições e fatores que estão implicados na produção de espaços.

Essas qualidades que se manifestam no conceito de heterotopia apresentado por Foucault aparecem ainda em noções como a de Rhythmanalysis, ou análise do ritmo, de Henri Lefebvre (2004). A Rhythmanalysis é uma abordagem sobre as complexidades e as variações rítmicas que podem ser observadas nas relações espaciais e perceptivas que são geradas em diferentes situações. Espaço e tempo são abordados em uma análise na qual os ritmos ou perspectivas rítmicas superam os esquemas unilaterais e dicotômicos que criam oposições entre elementos e fenômenos:

Agora a abordagem analítica se torna complexa, uma vez que beira realidades complexas. A análise clássica isola um elemento ou um aspecto do objeto. Isto é redutor por definição. As chamadas análises estruturais lançam luz sobre termos

\footnotetext{
75 Texto original: "Not so many years ago, the word 'space' had a strictly geometrical meaning: the idea it evoked was simply that of an empty area. In scholarly use it was generally accompanied by some such epithet as 'Eucliden', 'isotropic', or 'infinite', and the general feeling was that the concept of space was ultimately a mathematical one." (Lefrebvre, 1991:1)

${ }^{76}$ Texto original: "The quasi-logical presupposition of an identity between mental space (the space of the pholosophers and epistemologists) and real space creates an abyss between the mental sphere on one site and the physical and social sphere on the other." (Lefrebvre, 1991:6).
} 
opostos - dois a dois - a fim de estudar as suas relações e interações (assim: tempo e espaço, significante e significado, etc.). (LEFEBVRE, 2004:21, tradução nossa) ${ }^{77}$

O que o autor expõe é a possibilidade de se levar em consideração a desmontagem de estruturas que tendem a organizar as coisas de forma isolada e redutiva. O foco em uma espacialidade gerada a partir de interações conta com aspectos como a imprevisibilidade, que desarticula padrões e modelos. O imprevisível aparece no intervalo entre elementos quantitativos e qualitativos, surge no contato com o corpo, com a carne e com as complexidades que se manifestam na matéria. Lefebvre comenta:

O ritmo reúne aspectos quantitativos e elementos que marcam e distinguem momentos no tempo - e aspectos qualitativos e elementos que os mantêm juntos, consideram a "união" e o resultado deles. O ritmo aparece como tempo regulado, regido por leis de relação, mas em contato com o que é menos racional no ser humano: o vivido, o carnal, o corpo. Ritmos racionais, numéricos, quantitativos e qualitativos se sobrepõem em múltiplos ritmos naturais do corpo (respiração, o coração, fome e sede, etc.) embora não sem alterá-los. (...) No entanto, o natural e racional desempenham apenas um papel limitado nas análises dos ritmos, que são simultaneamente naturais e racionais, e nem um e nem outro. (LEFEBVRE, 2004: 19 , tradução nossa) $)^{78}$

As relações entre tempo e espaço propostas por Lefebvre levam em consideração interferências ambientais e informações que são processadas em superfícies e volumes irregulares, em matérias, elementos e situações que se manifestam no incalculável.

Compreendi os ritmos: árvores, flores, pássaros, insetos. Eles formam uma polirritmia com o ambiente que é a simultaneidade do presente (portanto, de presença), a aparente imobilidade que contém mil e um movimentos. (LEFEBVRE, 2004:26, tradução nossa) ${ }^{79}$

Essa sobreposição de elementos, de desvios, movimentos e interferências que produzem lugares ou espaço improváveis e imensuráveis sob o ponto de vista objetivo geram

\footnotetext{
77 Texto original: "Now the analytic approach becomes complex once it borders on complex realities. Classical analysis isolates an element or aspect of the object. It is reductive by definition. So-called structural analysis casts light on opposed terms - two by two - in order to study their relations and interactions (thus: time and space, signifier and signified, etc.)." (Lefrebvre. 2004:21)

${ }^{78}$ Texti original: "Rhythm reunites quantitative aspects and elements, which mark time and distinguish moments in it - and qualitative aspects and elements, which link them together, found the unites and result from them. Rhythm appears as regulated time, governed by relation laws, but in contact with what is least retional in human being: the lived, the carnal, the body. Rational, numerical, quantitative and qualitative rhythms superimpose themselves on the multiple natual rhythms of the body (respiration, the heart, hunger and thirst, etc.) though not without changing them. (...) However, the natural and the rational play only a limited role on the analysis of rhythms, which are simultaneous natural and rational, and neither one nor the other." (Lefrebve, 2004: 19)

${ }^{79}$ Texto original: "I have understood the rhythms: trees, flowers, birds and insects. They form a polyrhythmia with the surroundings: the simultaneity of the present (therefore of presence), the apparent immobility that contains one thousand and one movements, etc..." (Lefrebvre, 2004: 26)
} 
composições heterogêneas nas quais leves oscilações provocam o surgimento de caminhos e formas aleatórias ou desconhecidas. A observação de movimentos e de relações em eventos cotidianos favorece o confronto com variações que desconhecemos e que supomos estáveis quando as observamos rapidamente.

É importante observar ainda que a abordagem espacial de Forsythe, que se aproxima das colocações apresentadas por Foucault e Lefebvre, supera os modelos descritivos e analíticos e evidenciam aspectos de uma performatividade que está ligada às dinâmicas e ações que geram os eventos.

O termo performatividade ${ }^{80}$, que foi apresentado pela filosofia da linguagem, e mais precisamente por Austin, é assumido pelas vanguardas artística e pela arte contemporânea em projetos e procedimentos que destacam aspectos como mutabilidade e transitoriedade. A noção de performatividade coincide com as instabilidades que ela supõe e o enunciado performativo não se compromete com o estabelecimento de verdades e de pontos de vista rígidos. A performatividade diz respeito ao fazer, aos diferentes atos que se manifestam no mundo. Se alguns atos estabelecem padrões, outros são subversivos e geram novas possibilidades de relação. O importante é perceber que a noção de performatividade se adere ao movimento e não aos discursos que nomeiam e classificam os eventos sem que atuem sobre os seus processos.

Em confronto com os fetiches verdadeiro-falso e valor-fato da tradição filosófica, Austin propõe uma discussão sobre os enunciados que não são nem verdadeiros nem falsos, não descrevem nem servem para informar, mas sim fazem algo. Ele nomeia tal tipo de enunciado de performative, derivando esse nome do verbo perform, um verbo usual em inglês para ação. Numa intrincada argumentação, Austin defronta o que tinha sido um relativo consenso da filosofia da linguagem até então: usamos a linguagem para dizer o verdadeiro ou o falso. (PINTO, 2013)

Nesse processo de acionamento de forças o papel do espectador e a sua função passam a ser amplamente investigados. Teorias da recepção e propostas artísticas irão se ocupar com projetos inclusivos e com procedimentos que darão ênfase à ação do espectador na produção de arte. Da descrição para a ação uma série de fatores e atividades passaram a ser analisadas. Já não bastava a descrição de um evento, mas a observação de atos que geram complexidades

\footnotetext{
80 Existem diferentes abordagens que tratram da noção de Performatividade em seus mais variados desdobramentos. Autores como John Searle e Jacques Derrida, além de Austin, são alguns dos importantes referenciais sobre a questão da performatividade no contexto da filosofia da linguagem. Abordo o termo sob o ponto de vista da ação, dos atos que interpelam estruturas fixas e impositivas da linguagem.

81 Joana Plaza Pinto, 2013, em "Performatividade", matéria publicada na revista Cult. Disponível no site: http://revistacult.uol.com.br/home/2013/11/o-percurso-da-performatividade/. Acesso em outubro de 2015.
} 
nas relações que construímos com o mundo.

No texto a seguir me aproximo de três trabalhos de William Forsythe que em suas propostas geram ressonâncias espaciais que agem na distribuição e na ativação da percepção de artistas e espectadores. Os trabalhos selecionados apresentam características e qualidades que coincidem com a perspectiva espacial expansiva presente nas noções espaciais apresentadas por Foucault e Lefebvre e favorecem uma análise das variações espaciais cênicas exploradas por Forsythe.

A tensão e a negociação com bordas e parâmetros alargam a zona de ação de seus procedimentos para além dos limites que definem enquadramentos e contenções territoriais.

A abordagem dos trabalhos não seguirá uma ordem cronológica na qual as produções aparecem como estruturas em desenvolvimento progressivo e linear. Interessa-me antes pontuar aspectos e qualidades que surgem em diferentes momentos de sua produção e que confirmam o caráter experimental e especulativo de seus trabalhos e de suas incursões espaciais.

Heterotopia (2006), Kammer Kammer (2000) e Endless House (1999) apresentam traços que auxiliam na construção de um eixo de análise para onde convergem considerações sobre diferentes possibilidades de articulação espacial. Essas articulações dobram o espaço, sobrepõem interferências e evidenciam aspectos como desorientação, oscilação e variações temporais que sugerem a mobilização de campos perceptivos. Essas características dizem respeito ainda a ativação de diferentes elementos que constituem campos instalativos e dinâmicos que tendem a interpelar o espectador em seus sentidos.

A presença do espectador, que se torna participante e figura fundamental no processo de produção em arte será o foco de interesse de Forsythe, principalmente, nos trabalhos Objetos Coreográficos, que serão analisados no desenvolvimento desta pesquisa. Essa inclusão e solicitação ativa e física do espectador será abordada aqui como uma condição instalativa na qual interações espaciais reorientam o olhar e constroem espaços que surgem na dinamização e sobreposição de lugares. Essa orientação fica mais evidente na produção de Forsythe a partir do trabalho Endless House e aparecerá, sobretudo, em projetos e parcerias nas quais os diálogos com limites institucionais produzem tensões e perspectivas mais experimentais para as suas práticas.

No trabalho Heterotopia a justaposição de lugares e a proximidade do espectador favorecem o surgimento de arranjos e paisagens dinâmicas que se manifestam em múltiplas camadas. Sons que são projetados e que criam lugares, ações que transitam entre aberturas, buracos, esquinas que se movem e geram espacialidades transitórias. 
Em Kammer Kammer o olhar perambula, atravessa frestas, vê fragmentos de ações, oscila entre imagens ao vivo e monitores de televisão, imagina lugares que se escondem por detrás de praticáveis, tateia sons e percorre diferentes tempos e ritmos.

Em Endless House o espectador atravessa a cidade e acompanha a apresentação em duas situações bastante distintas. A primeira parte do trabalho acontece na Ópera de Frankfurt e a segunda no Bockenheimer Depot, quando o público é inserido fisicamente na zona de ação do trabalho.

As paisagens precárias e frágeis que se manifestam nesses trabalhos são como estruturas instáveis e em constante desequilíbrio. O ponto de fuga disperso e móvel reorienta constantemente o olhar e incentiva a percepção a giros e travessias por estruturas vazadas lugares em aberto, espaços em formação.

Essas composições espaciais que eu chamo aqui de estruturas vazadas contam com tremores e variações que confirmam o interesse de Forsythe por desdobramentos espaciais que acontecem a partir de desvios do olhar, da observação sob múltiplos pontos de vista e da presença do espectador como fator fundamental na ativação de espaços. 
Heterotopia ou sobreposição de lugares
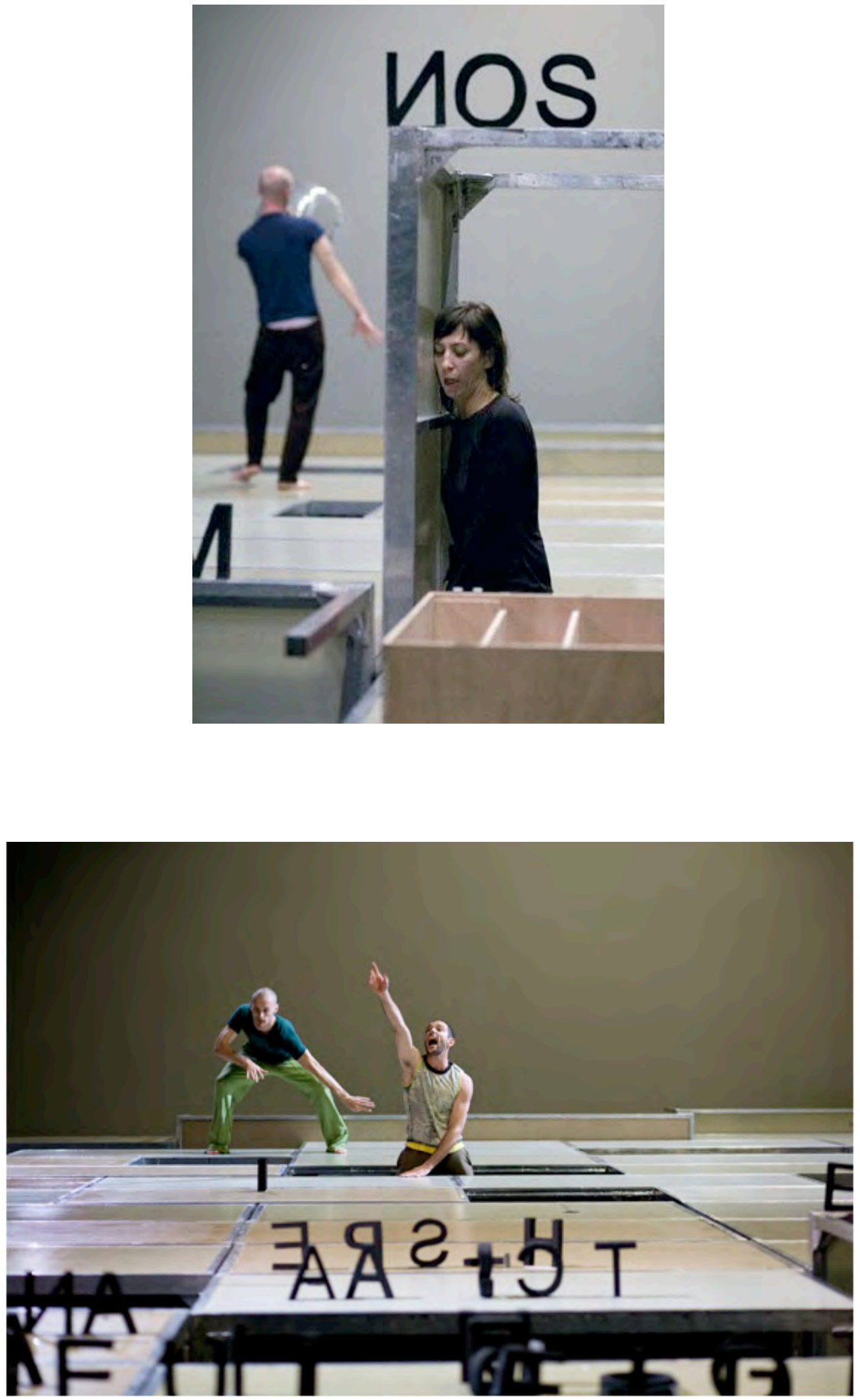
Um jogo de xadrez, um enorme tabuleiro que avança pelo espaço, que ganha volume e profundidade. Uma superfície formada por buracos, frestas, furos. Aquilo que acontece sobre e sob a superfície, uma área que é perfurada, que se dissipa em sons, reverberações vocais e físicas que geram espacialidades visíveis e invisíveis. Letras em três dimensões, palavras em construção, jogos aleatórios que incentivam a repercussão de sons, imagens, corpos, vozes e movimentos imprevisíveis e desconcertantes. É deste modo que o trabalho Heterotopia se aproxima da noção de Heterotopia abordada por Michael Foucault.

Heterotopia é também um conceito chave que dialoga diretamente com problemáticas e pressupostos colocados por essa pesquisa. A condição instalativa destacada neste estudo diz respeito à produção de espaços, à superação de limites que separam funções e desempenhos convencionados. Um lugar de múltiplas camadas, um espaço por onde transitam memórias coincide com uma área de negociações na qual se instalam novas dinâmicas. Respirações em diferentes tempos, dinamização de elementos, suportes e linhas que promovem a rearticulação contínua do espaço são algumas das características que se manifestam nesse lugar heterogêneo e sem acesso definido de entra ou saída.

O trabalho Heterotopia, criado em 2006, faz referência direta ao conceito de Heterotopia que Foucault apresenta no texto "De outros Espaços"

A estreia a os ensaios de Heterotopia aconteceram no Teatro Schiffbau, em Zurique, na Suíça. O teatro é um enorme espaço aberto que já foi usado para a construção de navios.

Gerald Siegmund $^{83}$ comenta o interesse de Forsythe, desde o trabalho Decreation, de 2003, em explorar relações entre som e movimento e destaca esta relação como o ponto de partida para a criação do trabalho Heterotopia. O modo como o movimento transita pelo corpo, percorre diferentes caminhos e afeta as cordas vocais, a produção e a emissão de sons são alguns dos principais pontos de observação e investigação do processo de criação do trabalho.

O posicionamento do corpo, tanto faz se contorcido ou entrelaçado, irá produzir um certo som como resultado direto que age na fisicalidade do corpo. Se você vocalizar uma das letras que estão dispostas(nas mesas), qual seria a sensação, e que tipo de som seria permitido que você fizesse? Movimento e formas são, portanto, traduzidos em som que abre um espaço acústico que funciona como o "outro espaço" do espaço que você realmente vê (SIEGMUND, 2009, tradução nossa) ${ }^{84}$.

\footnotetext{
${ }^{83}$ No texto "Spaces to Explore: Heterotopia by William Forsythe". Disponível no link: http://archive.kfda.be/projects/projects/2009/heterotopia/more. Acesso em junho 2015.

${ }^{84}$ Texto original: "Positions of the body, however contorted or twisted they may be, will produce a certain sound as a direct result of working on the physicality of the body. If you took one of the letters standing on the tables in your mouth, how would that feel, and what kind of sound would it allow you to make? Movement and shapes are
} 
A sonoridade produzida nas interações físicas entre voz, movimento, torções e articulações vocais reverberam no espaço e ecoam favorecendo a produção de sons irreconhecíveis ou que se aproximam de barulhos emitidos por insetos, por animais, línguas desconhecidas, murmúrios e vocalizações que geram ambientes sonoros estranhos aos ouvidos acostumados às batidas e aos compassos cotidianos. As relações entre as movimentações e a produção de sonoridades é atravessada por interferências, como as propostas pelo compositor Thom Willems, que explora e retrabalha eletronicamente as sonoridades produzidas pelos artistas em cena. Camadas sonoras e visuais se sobrepõem em um ambiente que articula diferenças na produção de espaços que exploram materialidades, fisicalidades e reverberações acústicas que fazem vibrar o corpo e geram lugares nos quais aspectos visíveis e invisíveis, palpáveis e impalpáveis se justapõem.

Gerald Siegmund $^{85}$ descreve o trabalho Heterotopia, de Forsythe, a partir do desenho de dois espaços que são separados por uma cortina espessa. O público, assim que entra no espaço da apresentação, se depara com uma grande formação de mesas ${ }^{86}$ que são organizadas de tal modo que aparecem entre elas espaços vazados, frestas e aberturas. A partir dessas aberturas os dançarinos aparecem inesperadamente, gesticulam e riem histericamente, como comenta Siegmund (2009). E é nesse ambiente por onde saltam gestos, sons, vozes, ruídos e ações inesperadas que o espectador é convidado a transitar e a criar caminhos. O público é livre para sentar-se ou mudar de sala sempre que quiser.

No primeiro espaço, onde estão dispostas as mesas, os dançarinos organizam letras aleatoriamente e transitam de um lado para o outro buscando sempre novas relações espaciais com os elementos que compõem esse ambiente. Eles executam ações e produzem sons que reverberam na sala ao lado. No percurso, os sons sofrem estranhas transformações que são logo ouvidas pelos dançarinos e transformadas em contorções e movimentos estranhos, como descreve Siegmund (2009). Aqui o som surge com um importante elemento na construção de intensidades, de camadas que se manifestam longe dos olhos e fazem a percepção atravessar paredes em um movimento no qual o espectador transita entre lugares onde ele está e não está ao mesmo tempo.

A proximidade das ações permite que o público perceba detalhes que em uma situação

\footnotetext{
thus translated into sound that opens up an acoustic space that function as the "other space" of the space you actually see". (Siegmund, 2009). Disponível no site: http://archive.kfda.be/projects/projects/2009/heterotopia/more.

${ }^{85}$ No texto "Spaces to Explore: Heterotopia by William Forsythe". Disponível no link: http://archive.kfda.be/projects/projects/2009/heterotopia/more. Acesso em junho 2015.

${ }^{86}$ Gerald Siegmund menciona o fato de que as mesas têm sido usadas com frequência nos trabalhos de Forsythe deste período.
} 
de palco, com a plateia mais distante do trabalho, passariam desapercebidos. Wiebke Hüster comenta essa proximidade:

Quinze bailarinos se revezam durante duas horas diante de apenas cem espectadores que podem circular livremente no enorme espaço. Todos são parte desta instalação, nenhum passo deixa de ser observado. Os diferentes grupos (de espectadores) se aproximam tanto da cena que, sob a luz forte, é possível ver claramente o esforço dos bailarinos na vermelhidão no rosto e o suor que sai dos poros." ${ }^{87}$

Além das movimentações que orquestram ações que acontecem diante dos olhos, há ainda a reverberação e o desdobramento de planos que parecem escondidos. Os intervalos espaciais, a utilização dos vãos abaixo da superfície das mesas e a projeção de sons que são ouvidos no segundo ambiente vibram ao mesmo tempo em que incentivam o olhar a percorrer lugares escondidos.

Os jogos e as tarefas que são acionados nas relações entre corpos, objetos e espaços se espalham em complexas redes neste ambiente instalativo que produz heterotopias. Silêncios, movimentos, sons, vozes, intensidades, planos, fragmentos e sobreposições ativam possibilidades relacionais com o trabalho. De uma sala para a outra, as variações e os estímulos revelam vestígios de materialidades que escapam de delimitações físicas espaciais. O espaço é agora dinâmica, ou não-lugar no qual heterotopias são geradas.

O conceito de Heterotopia coincide aqui com o teatro, ou com o lugar teatral no que se refere a produção de espaços simultâneos que reconfiguram espacialidades e conceitos:

\begin{abstract}
Para Foucault, o teatro é como um "contra-lugar". Ele tem a capacidade de apresentar diferentes lugares no palco, quer ao mesmo tempo ou sucessivamente. Como uma biblioteca, ele faz cortes "temporais" para manter vários tempos presentes ao mesmo tempo. Se qualquer peça de teatro pode fazer isso, o que faz uma peça que se chama explicitamente Heterotopia? A Heterotopia de William Forsythe é, como eu gostaria de sugerir, a própria heterotopia das peças de teatro e dança convencionais: é o espaço onde as formas comuns de interação social e a forma como elas são representadas em um contexto teatral são questionadas e exploradas. (Sigmund, 2009) ${ }^{88}$
\end{abstract}

\footnotetext{
${ }^{87}$ Texto original: "15 Tänzer verwandeln sich zwei Stunden lang in der riesigen Halle - vor nur einhundert Zuschauern, die sich frei im Raum bewegen dürfen. Alle sind Teil dieser Installation, kein Schritt bleibt unbeobachtet. Sehr nahe kommen sich die sonst getrennten Gruppen, so nahe, dass im grellen Licht der Szene ganz deutlich zu sehen ist, wie die Anstrengung den Tänzern die Röte ins Gesicht und den Schweiß aus den Poren treibt.” Por Wiebke Hüster. Texto disponível no lik: http://www.deutschlandfunk.de/die-heterotopien-deswilliam-forsythe.691.de.html?dram:article_id=50095

${ }^{88}$ Texto original: "For Foucault, the theatre is such a counter-site. It has the capacity to present different places on stage, either at the same time or successively. Like a library, it makes cuts through time to hold various times present at once. If any theatre piece can do this, what does a piece do that explicitly calls itself Heterotopia? Heterotopia by William Forsythe is, as I would like to suggest, the heterotopia of conventional theatre and dance pieces: it is the space where the ordinary ways of social interaction and the way they are represented in a theatrical context are questioned and explored." (Siegmund, 2009).

Texto disponível no site: http://archive.kfda.be/projects/projects/2009/heterotopia/more. Acesso em abril 2015.
} 
Heterotopia estimula os sentidos e faz com que a percepção transite por diferentes focos de ação. Perspectivas sonoras e visuais promovem experiências que passam pela seleção e pela escolha particular de cada uma das pessoas que compõe o grupo de espectadores. Cada um fará seu recorte, produzirá seu sentido ou mesmo criará ligações com o trabalho que extrapolam lógicas temporais pautadas em narrativas cronológicas. Diferentes elementos e intensidades provocam mudanças constantes de foco. Aquilo que é observado some, se transforma em som, reverbera no espaço enquanto novas ações se inauguram. Através da fragmentação a percepção se movimenta por percursos não usuais. $\mathrm{O}$ espectador é inserido em um amplo campo perceptivo desprovido de uma sequência narrativa ou lógica o que desperta a atenção para detalhes e variações que cotidianamente passam, muitas vezes, desapercebidas.

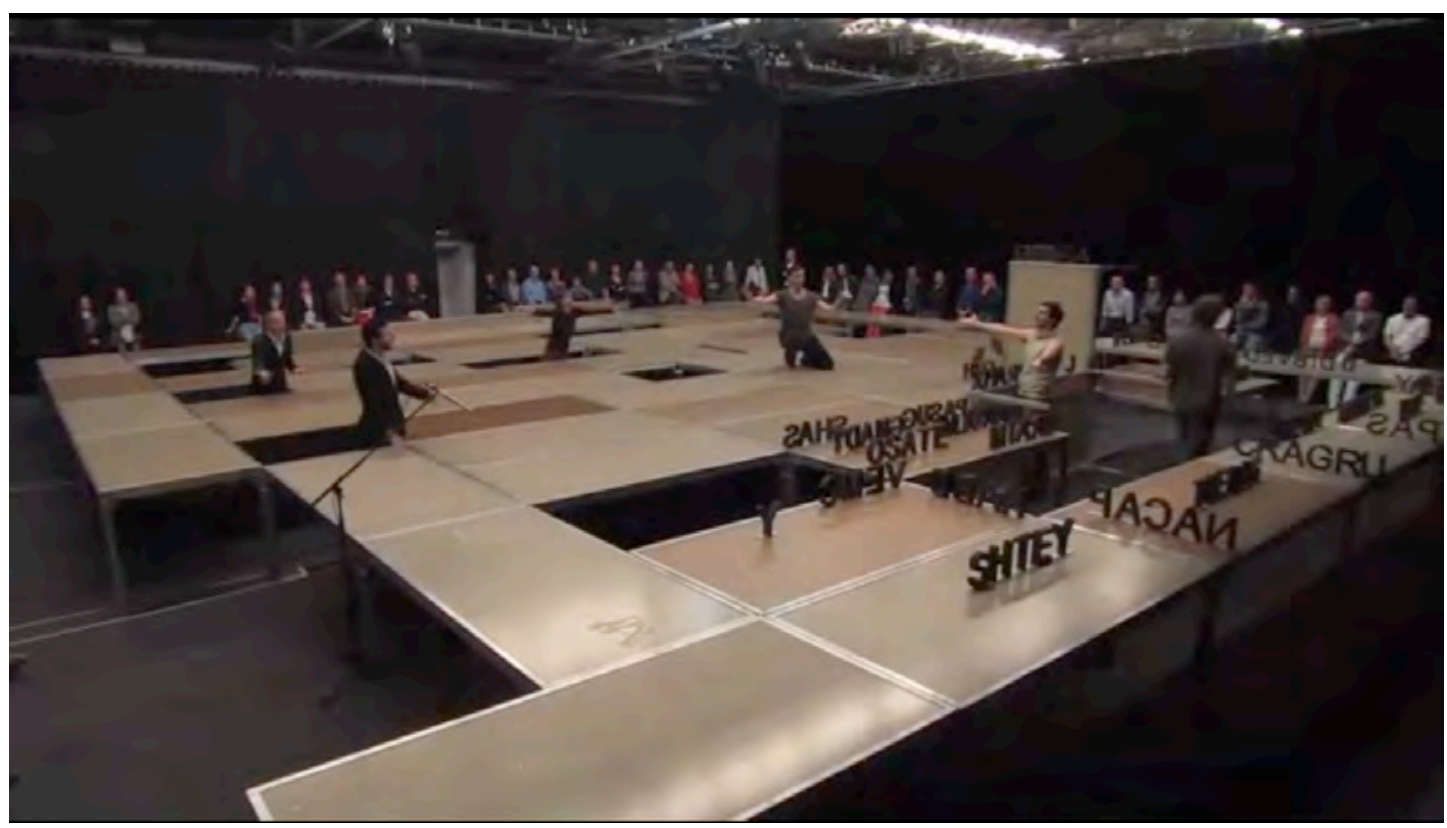

Registro de uma das apresentações em vídeo ${ }^{89}$

Esse cruzamento de informações incentiva a descoberta de espaços diferentes, ambíguos e contraditórios. A experiência e a produção de heterotopias se relaciona com qualidades e propriedades físicas. E as interferências produzidas pelas heterotopias agem na desestruturação de sensos comuns estabelecidos.

A noção de Heterotopia pontua diálogos do trabalho com aspectos e investigações filosóficas que são assim comentados por Forsythe:

A filosofia pode ser uma ferramenta muito útil. Mas ela não tem que exigir ou funcionar como um imperativo. Foucault foi útil para começar alguma coisa. Mas eu

\footnotetext{
${ }^{89}$ Disponível no link: https://www.youtube.com/watch?v=kQv1J19BPXU
} 
não sei se ele foi útil para terminá-la. Eu tenho usado Foucault em várias ocasiões. E eu acho que ele é muito sugestivo em termos procedimentais. (William Forsythe. Entrevista: Claire Lee, 2013) ${ }^{90}$

Outro dado importante que aparece neste trabalho e nas relações que Forsythe estabelece com o conceito de Heterotopia é a utilização de referenciais literários e o modo como esses pensamentos se manifestam espacialmente em sua produção. É freqüente o aparecimento de letras, em formatos tridimensionais em seus trabalhos, a influência da literatura e a citação de livros e autores. As letras tridimensionais transformam a palavra, como metáfora, em matéria e elemento que interage com outros estímulos que compõem a zona de ação de seus trabalhos. A palavra, a arquitetura, referenciais literários e teóricos, equações matemáticas, princípios da física, as relações possíveis do corpo com o entorno, a percepção, impactos físicos, aquilo que acontece antes da elaboração de conceitos e regras fechadas, a reverberação de ambientes sonoros e a interrelação entre espaços subjetivos e materiais são alguns dos pontos difusos que se ligam nas paisagens móveis, transitivas e frágeis de Forsythe.

Essa interposição de estímulos sensoriais que acontecem em detalhes e nas reverberações que atravessam as salas de Heterotopia aparecem nos comentários de Schechner, no texto Seis Axiomas, que abordarei na seção Formações Temporárias, como condições vinculadas à multiplicação e à flexibilização de focos que acionam campos afetivos, sensoriais e intelectuais. Os estímulos sensoriais provocam sensações que alargam e contraem a percepção espacial. As considerações de Schechner auxiliam na visualização de características e propriedades que aparecem neste trabalho:

\begin{abstract}
A sobrecarga sensorial leva a uma sensação de um pequeno espaço explodindo porque ele está muito cheio. Eventos esparsos evocam a sensação de um espaço que é grande, mal povoado, com a maior parte do seu volume ainda inexplorada. A variedade de focos múltiplos se estende de um extremo ao outro incluindo todos os pontos intermediários. (SCHECHNER, 1994:37, tradução nossa) ${ }^{91}$
\end{abstract}

Neste "caleidoscópio intelectual e sensorial"92 as informações transitam por um

\footnotetext{
${ }^{90}$ Entrevista disponível no link: http://www.koreaherald.com/view.php?ud=20130410000930. Acesso em maio de 2015. Texto original: "Philosophy can be a very useful tool. But it doesn't have to demand or function as an imperative. Foucault was useful to start something. But I don't know if he was useful to finish it. I've used Foucault on a number of occasions. And I find that he is very suggestive in terms of procedurals." (Lee, 2013)

91 Texto original: "Sensory overload leads to a feeling of a small space exploding because it is so full. Sparse events evoke the feeling of space that is large, barely populated, with most of its volume still unexplored. The range of multi-focus extends from one extreme to the another including all intermediate points." (Schechner, 1994:37)

92 Termo utilizado por Schechner no contexto da citação acima.
} 
ambiente no qual as faculdades cognitivas e afetivas são muitas vezes incompatíveis ou contraditórias. Os espectadores puxam os mais diversos fios desta trama espacial para construírem suas narrativas ou simplesmente transitam de um ponto ao outro deixando-se levar por volumes sonoros e qualidades sensoriais.

O olhar, as sensações e as abordagens analíticas se multiplicam nesse campo produtor de Heterotopias. A variação dos focos e pontos que acionam os sentidos é também tema e condição do trabalho que abordarei a seguir: Kammer Kammer, no qual o espectador, ainda sentado e da posição da plateia, se depara com ações simultâneas que pulverizam o olhar para diferentes intervalos e frestas que se apresentam no palco.

As aberturas e os deslocamentos gerados no trabalho Heterotopia evidenciam e permeiam abordagens sugeridas por Foucault. Entretanto, esse diálogo de Forsythe com paisagens em construção, nas quais oscilam múltiplos pontos de observação e experiências, acontece em outros contextos e principalmente em suas propostas que enfatizam aspectos e condições instalativas, como os Objetos Coreográficos.

O trabalho a seguir, Kammer Kammer, de 2000, foi produzido anos antes de Heterotopia e apresenta uma configuração espacial na qual a fragilidade se articula entre praticáveis, monitores de televisão, gravações áudio-visuais e composições físicas que aparecem fragmentadas em cena. Essa condição frágil, que faz o acontecimento vibrar em variações que transitam entre indicações e marcações estabelecidas, foram constatadas em uma pesquisa de campo na qual tive a oportunidade de acompanhar o dia-a-dia de trabalho da Companhia na remontagem de Kammer Kammer, em 2015. A experiência com a The Forsythe Company e com o próprio William Forsythe alertou meus olhos para linhas finas e sutis que vibram nas grandes estruturas presentes neste trabalho. Aquilo que parece fixo e determinado oscila de um ensaio para o outro e de uma apresentação para a outra. Forsythe dá ênfase a essas aberturas que mantém o trabalho em movimento. Ele solicita dos artistas um estado de atenção no qual a produção de movimentos está atrelada a desvios de caminhos estabelecidos.

A revelação de contrastes e precariedades em um trabalho que acontece no palco e que faz uso de uma enorme variedade de recursos técnicos foi a grande surpresa que fez meus olhos se atentarem para as sutilezas, para a observação de variações que mantém as estruturas sempre vivas e atuais. As dinâmicas que acionam a grande máquina na qual o trabalho se apresenta surge de detalhes, de aberturas e fragilidades que confrontam os corpos com outros corpos e com materialidades que agem na produção de presenças. 
Kammer Kammer ou perambulações do olhar

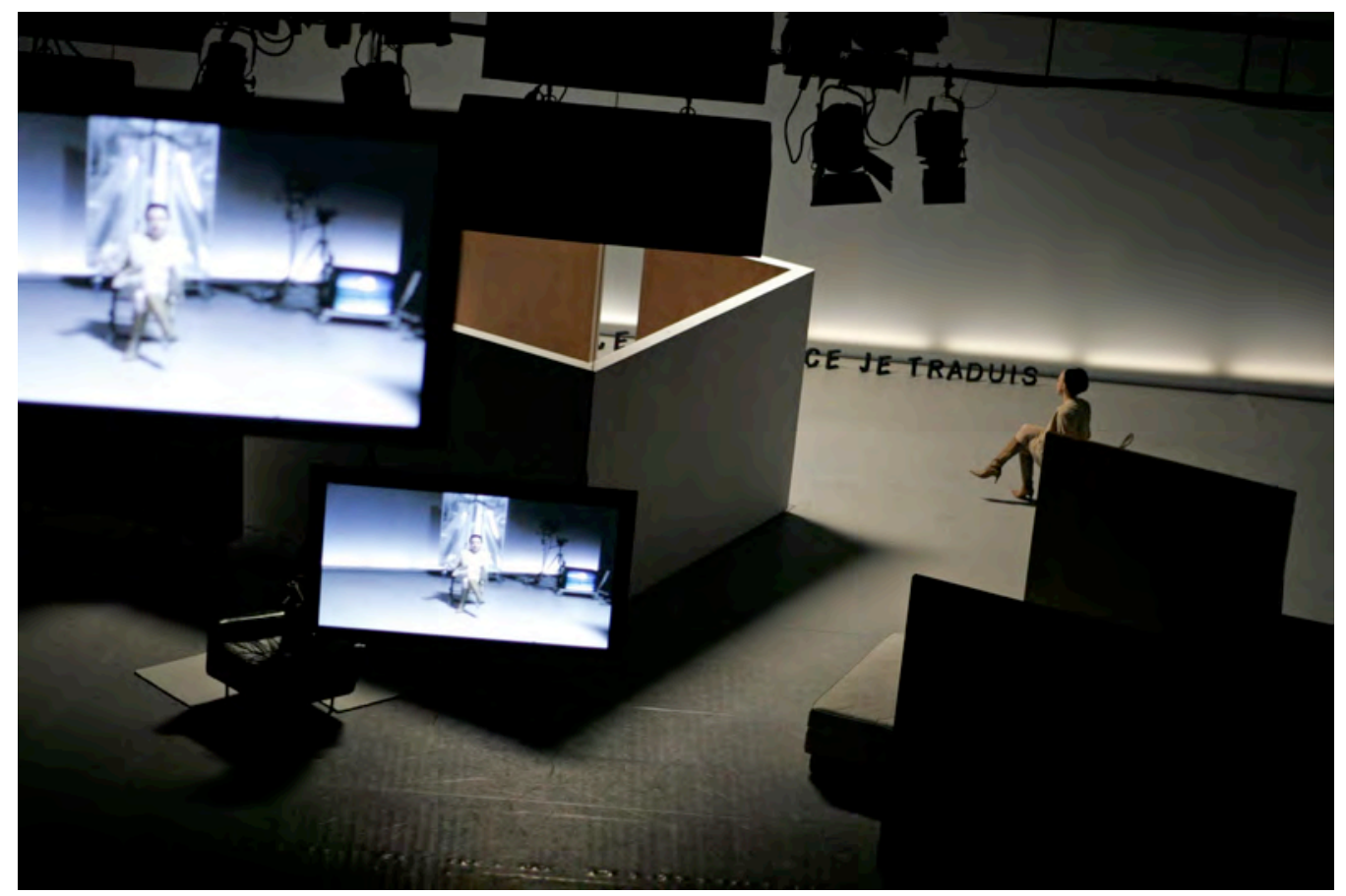

(Kammer Kammer)

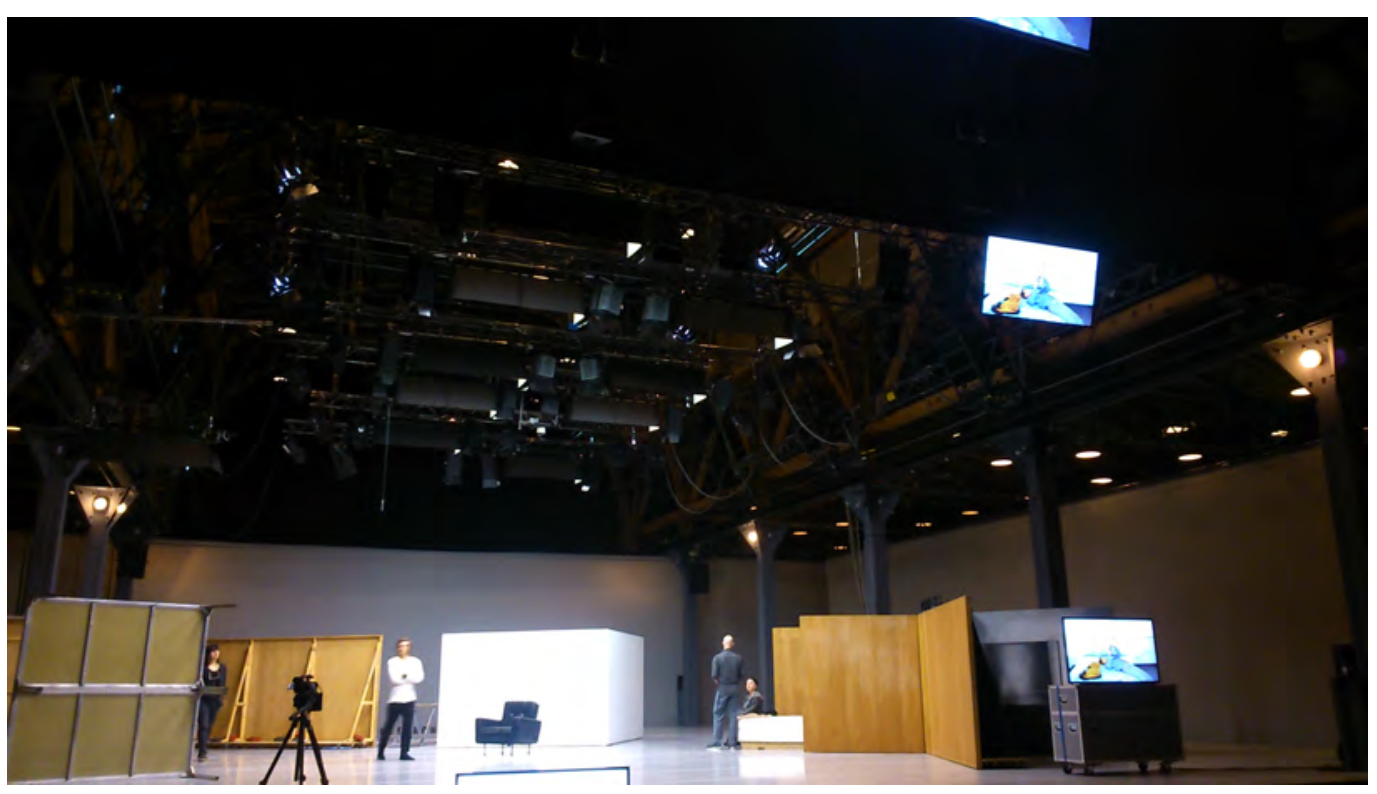

(arquivo pessoal. Ensaio, abril 2015) 
Dia 16 de março de 2015, sol em Frankfurt depois de um longo e escuro inverno ${ }^{93}$.

A remontagem de Kammer Kammer, que aconteceu no período de 16 de março a 10 de abril de 2015, em Frankfurt, teve a seguinte programação: Aulas de balé, de segunda a sextafeira, no período da manhã, das dez e meia ao meio dia, e ensaios do meio-dia e meia às dezoito horas. Os intervalos, de uma hora de almoço, estavam previstos para às quatorze horas.

A peça Kammer Kammer foi montada pela primeira vez no ano 2000, quando William Forsythe atuava ainda como diretor do Balé de Frankfurt. O trabalho, que foi remontado algumas vezes pelo Balé de Frankfurt e também pela The Forsythe Company, foi escolhido para a temporada de despedida do coreógrafo ${ }^{94}$.

Nas anotações seguintes esboço uma rotina de trabalho da Companhia e pontuo qualidades que persistem, que surgem no ambiente de ensaio e que estarão também presentes nas apresentações, como a atualização das dinâmicas entre os artistas e a manutenção de uma certa fragilidade nas partituras de movimentos. Ambas qualidades, ou características, se aproximam e até mesmo se confundem quando lançadas a uma análise mais detalhada que aborda o movimento sob o ponto de vista da instabilidade, das variações que acontecem no contato com o meio.

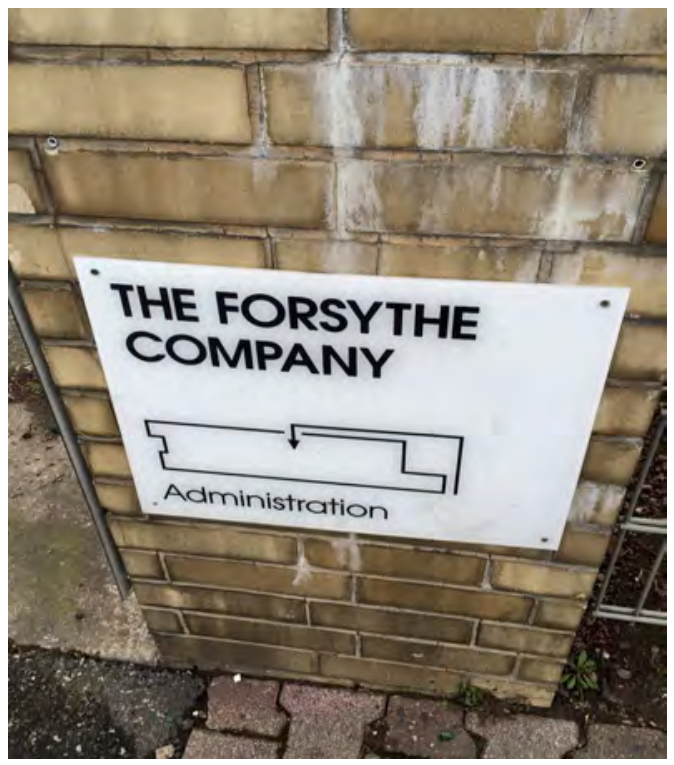

(arquivo pessoal. Ensaio, abril 2015)

\footnotetext{
${ }^{93}$ Registros durante a remontagem de Kammer Kammer no estúdio da The Forsthy Company, na rua Schmidtstraße 12, e no Bockenheimer Depot, na rua Carlo-Schmid-Platz 1, ambos em Frankfurt am Main.

${ }^{94}$ A temporada de despedida aconteceu nos dias 17, 18, 19, no mês de abril de 2015, no Bockemheimer Depot, em Frankfurt.
} 
Está marcada para às 10h30 da manhã a primeira aula de balé do primeiro dia de ensaio da última temporada de trabalho da The Forsythe Company. A língua inglesa facilita a comunicação e aproxima artistas de diferentes nacionalidades e formações que se reúnem para a última remontagem prevista do trabalho Kammer Kammer, que estreou no ano 2000, na cidade de Frankfurt.

O envolvimento de todos da equipe, a gentileza e a abertura do processo para estagiários e interessados são características que pontuam os bastidores da Companhia The Forsythe Company fundada por William Forsythe, em 2004.

A remontagem de Kammer Kammer contou, fundamentalmente, com registros e gravações de vídeos de antigas montagens. Artistas e todos os demais envolvidos em processos anteriores auxiliaram no levantamento e na atualização de memórias que foram compartilhadas com os novos integrantes.

Começa a aula.

Entro na sala de ensaio para fazer as minhas primeiras anotações e logo ouço o som de um piano. A aula de balé95 já começou. O professor de dança, um dos integrantes da The Forsythe Company, e o pianista conversam por gestos que alteram o compasso da música e da aula. As estruturas conhecidas do balé estão lá, mas flexibilizam-se nos corpos de tal forma que quase desaparecem. É como se as posições sugerissem o surgimento de vetores que orientam o movimento tanto para lugares já conhecidos do balé quanto para direções desconhecidas e inesperadas. Observando as aulas, é possível constatar que os bailarinos pesquisam os movimentos enquanto se deslocam através das sequências sugeridas. Há sempre linhas que fogem, que encontram novos percursos mesmo dentro de uma estrutura préestabelecida.

O que percebo, no decorrer da aula, é que o corpo, aos poucos, se projeta em múltiplos níveis, intensidades e qualidades que alteram a composição do espaço. Os vetores de uma ordem, como as do balé clássico, agem como pontes que auxiliam no desdobramento dos movimentos em inúmeras variações. Esses vetores são, nesse contexto, catalisadores de abalos, contrações e expansões que impulsionam o corpo para uma rede de relações. E é nesse contexto que a presença e o deslocamento desses corpos em trajetos instáveis altera as

\footnotetext{
${ }^{95}$ Aulas de balé clássico são oferecidas pelas manhãs aos bailarinos. Alguns optam por outras práticas. Ver livro depoimento da artista.
} 
perspectivas espaciais das paisagens que eles percorrem.

As aulas diárias de balé antes dos ensaios e o modo como cada um se relaciona com os exercícios favorece a ampliação dos movimentos, a multiplicação de diferenças e desvios, a ativação da percepção e a produção de um fluxo de pensamentos que é gerado em movimento. Surgem níveis de corporalidade nos quais uma espécie de percepção ambiental é ativada.

Há ainda um clima de descontração que favorece a experimentação e a interação com o outro. O processo é rigoroso, as aulas acontecem diariamente e as jornadas de trabalho são longas. Entretanto, há um clima de informalidade e liberdade que auxilia o processo investigativo. Os movimentos embora sejam estáveis em seus amplos traços espaciais, apresentam infinitas variações e vibrações quando se colocam em ação e nas relações com outros corpos. Neste ponto, é importante frisar o estímulo e a atenção de Forsythe para esses momentos de atualização do movimento. $\mathrm{O}$ frescor e os pequenos abalos que compõem as sequências são os principais ponto de observação e incentivo do coreógrafo nos ensaios que seguem as aulas de balé.

Para a remontagem de Kammer Kammer, os artistas assistiram aos vídeos de apresentações anteriores, experimentaram sequências, organizaram o espaço e ensaiaram pequenas frases de movimentos sozinhos, em duplas, trios e com o grupo todo.

Em um total de quase um mês de ensaio, a maior parte do trabalho aconteceu no estúdio da Companhia. Apenas na última semana do processo de remontagem é que os ensaios técnicos passaram a acontecer no Bockenheimer Depot, local onde aconteceu a estreia no dia 10 de abril de $2015^{96}$.

A seguir, apresento algumas imagens do estúdio da companhia e de momentos dos ensaios que acompanhei entre março e abril de 2015, em Frankfurt.

\footnotetext{
${ }^{96}$ A reestreia de Kammer Kammer marcou a início da última temporada da The Forsythe Company sob a direção artística de William Forsythe. A Companhia, composta por artistas que trabalham desde o Balé de Frankfurt com Forsythe e por artistas que se somaram ao elenco recentemente, será transformada em uma nova Companhia que terá direção de Jacopo Godani e será formada por um novo grupo de artistas. Certamente, será mudado em breve também o nome da companhia.

Na ocasião da reestreia e logo após a apresentação, houve uma recepção e uma homenagem ao trabalho e a importante atuação de Forsythe em Frankfurt. Forsythe agradeceu a todos e disse que todo o trabalho só foi possível graças a aos artistas com quem trabalha e pontuou ainda que trinta anos, período que ele trabalha em Frankfurt, é um tempo saudável de relação.
} 


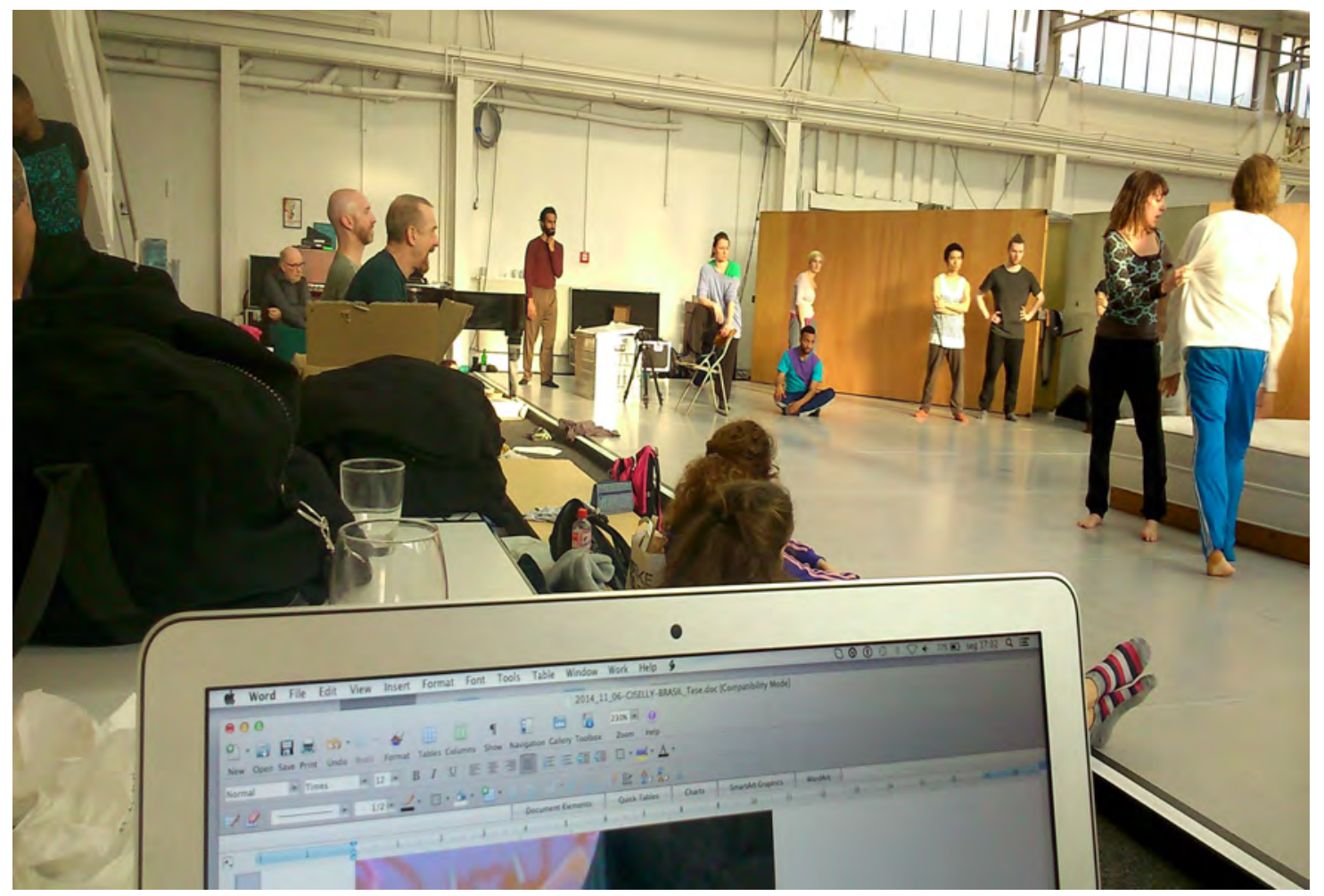

(arquivo pessoal. Ensaio, abril 2015)

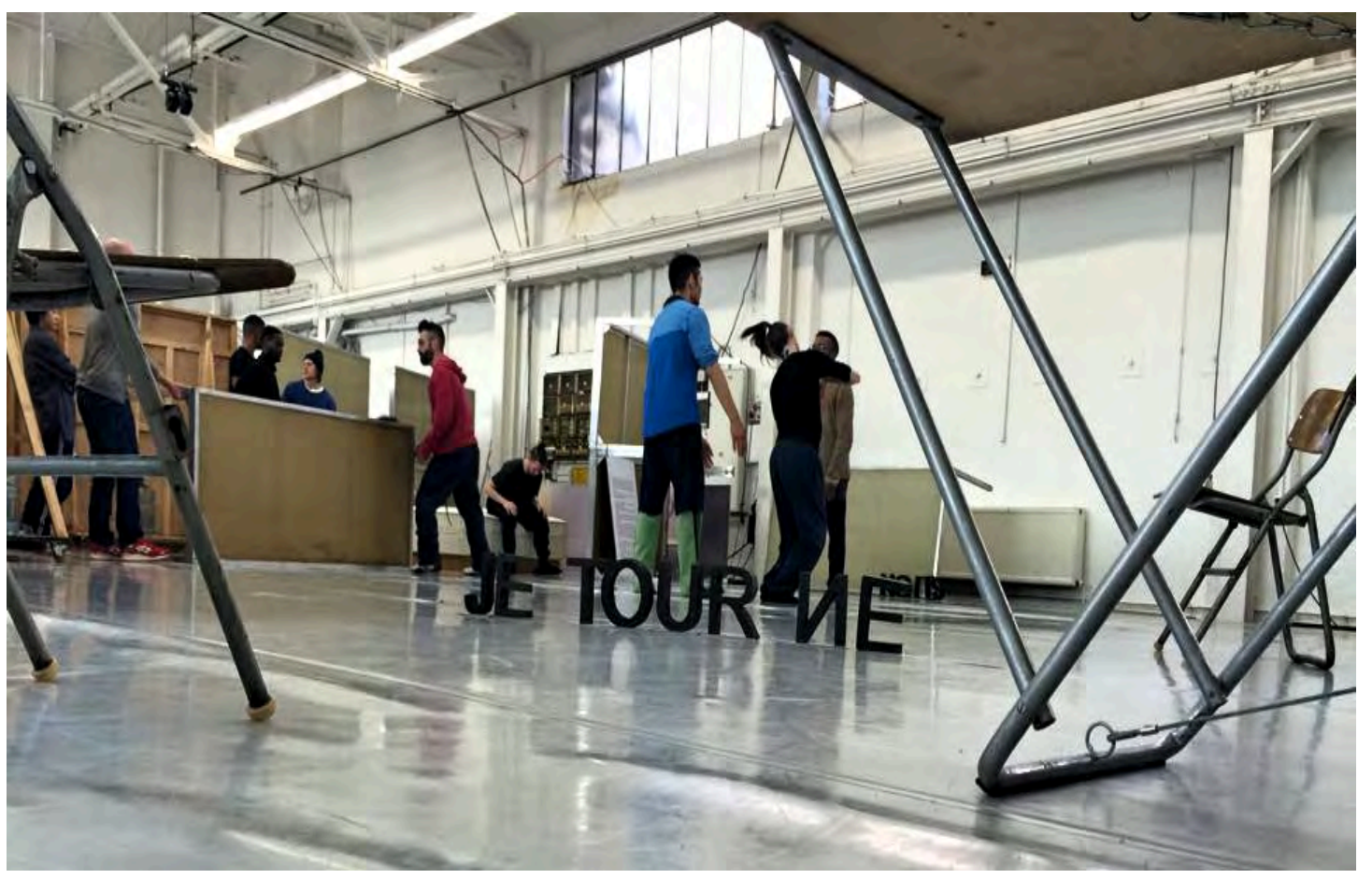

(arquivo pessoal. Ensaio, abril 2015 ) 
Kammer Kammer, a palavra aqui repetida pode ser traduzida, do alemão para o português, como câmara, despensa ou mesmo espaço ou quarto.

Conforme mencionado acima, este trabalho foi criado no ano 2000 pela então companhia Balé de Frankfurt. O espetáculo conta com uma forte presença de elementos fílmicos, como telas, cenas que são filmadas ao vivo e projetadas instantaneamente para o público, gravações e projeções com efeitos visuais, monitores dispostos no palco e em frente ao espaço da plateia e cenários articuláveis com pinturas e imagens de fundo que dialogam com os textos e as ações. Kammer Kammer articula diferentes procedimentos em uma composição que promove encontros entre práticas e conceitos como teatro, dança, artes visuais, cinema e filosofia. A crítica de dança Roslyn Sulca ${ }^{97}$ observa que este trabalho pontua o crescente interesse de Forsythe por criações que funcionam não só no contexto da dança, como também no âmbito das artes visuais e da performance.

O espaço, em Kammer Kammer, é flexível, surge na articulação, na montagem e na desmontagem de lugares. O cenário, composto por painéis deslizantes que são manipulados pelos bailarinos, multiplica os campos de ação, fragmenta a narração e faz a atenção do espectador girar em órbitas imprevisíveis. Além das estruturas articuláveis que alteram constantemente o panorama visual e o campo perceptivo do espectador, as telas direcionadas para o público e com projeções de vídeos gravados, em sua maioria, ao vivo, promovem transferências constantes do olhar. É preciso escolher o que será visto. E é nesse trânsito frenético que os encadeamentos lógicos ou críticos deixam de orientar a percepção. Forças sonoras e, principalmente, visuais atuam na desorientação do olhar e dos sentidos. $\mathrm{O}$ espectador é lançado em uma zona de intensidades que estimula incessantemente o olhar para diferentes direções.

Kammer Kammer é uma composição cênica ou coreográfica inspirada no romance Outline of My Lover, de Douglas A. Martin, e no ensaio Essays Irony is Not Enough : Essay on my Life as Catherine Deneuve, da poeta e acadêmica Anne Carson. A montagem, criada a partir de dois textos literários e de um projeto de vídeo de Martin Schwember, trata de duas histórias de amor que abordam a homossexualidade e que são contadas simultaneamente. Textos e movimentações criam paisagens múltiplas e dinâmicas nas quais os limites entre dança, teatro, cinema, realidade e ficção se confundem.

Antes do público ter acesso as suas poltronas os bailarinos dançam uma partitura de trinta minutos. Os espectadores não vêem o que se passa no palco, apenas ouvem

\footnotetext{
${ }^{97}$ No texto: "Watching the Ballett Frankfurt, 1988-2009", p.14. Livro: William Forsythe and the Practice of Choreography, 2011.
} 
movimentações e uma música que acompanha essa introdução.

Quando o público é convidado a entrar os bailarinos estão no palco se aquecendo, repassam sequências enquanto um dos dançarinos os dirige, corrige frases, detalhes e dá opinião sobre a qualidade dos movimentos. O bailarino em questão faz o papel de Forsythe e, de forma crítica e bem humorada, indica o comportamento de um diretor que está atento a cada gesto e que dança com os bailarinos enquanto explica detalhes sobre os movimentos. Há ainda um narrador que aparece no meio desta ação que acontece no palco. Ele se dirige ao público, conversa com a plateia e faz com que o começo da peça decorra de uma transição na qual a chegada do público passa a fazer parte do início da apresentação. Antony Rizzi que atua aqui como narrador é também uma das figuras centrais da trama, "a boy in the blue sock hat" (garoto com chapéu de meia azul), que relata sua paixão por um homem, que seria na trama uma estrela do rock que é apenas mencionada na encenação. O outro eixo dramático que cruza essa narração fragmentada e interpelada pelos mais diversos estímulos é a aparição de Dana Caspersen como Catherine Deneuve. Deneuve, na peça, é uma professora que se apaixona por uma de suas alunas. Conversas, reflexões e referências filosóficas se cruzam nesse cenário onde os filósofos Sócrates e Sappho são algumas vezes mencionados.

Philip Bussmann e Agnieszke Trojak são responsáveis, respectivamente, pela criação dos filmes experimentais e pela coordenação das filmagens ao vivo que transmitem aos espectadores trechos de cenas que acontecem por detrás dos praticáveis.

A diversidade de elementos e recursos compõe uma paisagem plural que se articula, se monta e se desmonta diante de olhos que perambulam de um canto ao outro da montagem.

Esse encontro, diluição, sobreposição de lugares mentais e físicos e perambulação por lugares em Kammer Kammer é analisada por Forsythe na seguinte entrevista ${ }^{98}$ :

Rebecca Groves: Kammer Kammer talvez seja mais uma peça teatral do que uma
coreográfica. Qual é o papel das sequências de dança, no contexto desta
performance?
William Forsythe: Há uma linha fundamental no início do texto de Carson que
introduz uma distinção entre fantasia mental e realidade: "Enquanto isso, o corpo
persiste." De tudo que nós falamos sobre o etéreo de emoções, elas residem
inteiramente no corpo. Os trios nos colchões são a expressão física da turbulência
emocional. Os cortes na performance para essas cenas são enquadradas em formato
de vídeo. Algumas vezes elas só são visíveis através de aberturas "frestas" nas
paredes (nos praticáveis). Esses trios aparecem como um fluxo contínuo de
conexões físicas e recuos acontecendo em um segundo plano sem começo nem fim.
Cinco dos trios nos colchões foram, portanto, extraído de Kammer Kammer e
apresentados de uma forma menos agitado como uma peça autônoma chamada

\footnotetext{
${ }^{98}$ Rebecca Groves, dramaturga da Forsythe Company, em conversa com o coreógrafo William Forsythe sobre Kammer/Kammer. Entrevista disponibilizada por Thierry Guiderdoni, assistente artístico e responsável pela agenda de Forsythe.
} 
Duplo / Individual. ${ }^{99}$

O trabalho sobrepõe tempos e espaços em ações múltiplas que percorrem o palco e que saltam de frestas e encaminhamentos inusitados. $\mathrm{O}$ olhar corre pelo palco e varre fragmentos que surgem e desaparecem. Há um processo contínuo de formação e dispersão que provoca o susto e a ativação da percepção. A narrativa do trabalho é formada por turbulências e cortes que multiplicam as possibilidades de leitura e relação com a composição cênica. E é nessa desarticulação de trajetos estáveis que o inesperado aciona os sentidos para os cantos, para os vãos entre os praticáveis e para aquilo que vemos parcialmente. Lançamos o olhar para lugares que não vemos, tentamos nos localizar juntando pedaços de ações que já não existem mais e somos surpreendidos pela possibilidade de acessos inesperados que dificultam uma localização estável e previsível. As mais variadas sensações e abstrações habitam o corpo essa fisicalidade complexa que interpõe tempos e espaços em articulações que não apresentam um início ou um fim definido.

Os dançarinos atuam em uma estrutura móvel que gera desvios e expõe fragilidades que transitam entre diferentes estímulos que surgem e somem.

Aquilo que foge aos olhos, aos sentidos, oferece condições para o aparecimento do novo, de variações múltiplas de um fenômeno. A ausência do previsível e do já conhecido surge, neste caso, como condição ou qualidade que nos permite reconhecer a presença como um clarão, luminosidade ou como centelha que nos joga para um momento que não tem passado e nem futuro. Apreendemos o inapreensível.

A autora Heidi Gilpin (2011) ${ }^{100}$ apresenta a noção de lightness ${ }^{101}$ como qualidade que emerge do desaparecimento ${ }^{102}$, do desequilíbrio e da falta. Pode-se dizer, que a presença, como lightness, se manifesta na oscilação e no surgimento do inesperado, o que coincide, de

\footnotetext{
${ }^{99}$ Texto original: "Rebecca Groves: Kammer/Kammer is perhaps more of a theatrical piece than a choreographic one. What is the role of the dance sequences in the context of this performance?

William Forsythe: There is a poignant line at the beginning of Carson's text that introduces the distinction between mental fantasy and reality: "Meanwhile the body persists." For all we say about the ethereality of emotions, they reside entirely in the body. The mattress trios are the physical expression of emotional turmoil. The performance cuts to these scenes from time to time and frames them with the video design. Sometimes they are only visible through cracks in the walls. They feel like a perpetual stream of physical connections and avoidances going on in the background without beginning or end. Five of the mattress trios have also been excerpted from Kammer/Kammer and presented in a less agitated form as a stand-alone piece called Double/Single"

${ }^{100}$ No texto "Aberrations of gravity", no livro "William Forsythe and the practice of choreography, organizado por Steven Spier”, 2011.

${ }^{101}$ Lightness como luminosidade.

${ }^{102}$ É importante pontuar que a autora aborda o conceito de desaparecimento como evento traumático e como perda total da consciência. Embora eu me aproprie de reflexões e noções apontadas pelas autora, a noção de desaparecimento ou de ausência que emprego aqui diz respeito a uma mobilização profunda da consciência, uma perda temporária de referenciais e a descoberta de novos estímulos para a percepção.
} 
acordo com Gilpin (2011) com a experiência de um evento traumático. Gilpin cita o exemplo de um tremor de terra, evento no qual acontecem importantes transformações naquele que o vivencia, mas que os registros produzidos no instante do evento são inacessíveis. As instabilidades que acontecem no corpo e que não podem ser nomeadas ou descritas durante e nem mesmo após o evento instauram diferenciações e mudanças de referenciais e sentidos. Esse instante de deslocamento, no qual os pontos de vista se multiplicam e a estabilidade do olhar é abalada, coincide com condições e experiências muitas vezes vividas por artistas e espectadores.

\begin{abstract}
"Luminosidade" é uma condição em que alguma coisa acontece - um acidente, um evento traumático, um fracasso, um desaparecimento - para além da capacidade de alguma forma de notação. Essas questões podem ser transmitidas através do trabalho do coreógrafo / diretor William Forsythe. No trabalho de Forsythe, "luminosidade" é uma qualidade que emerge do fracasso, do desaparecimento e do desequilíbrio. (GILPIN, 2011: 113, tradução nossa) $)^{103}$
\end{abstract}

A autora pontua ainda que a noção de failure, falta, contém em si a noção de absence, ausência. Ambos conceitos nos remetem àquilo que falta, ao erro, à inabilidade em desempenhar uma função e àquilo que não é bem sucedido, por exemplo. É na falta e na ausência que surgem as lacunas, os lugares improváveis por onde circularão novos fluxos e onde se desenharão estruturas móveis e dependentes de relações e atualizações constantes. Pode-se dizer que é no instante em que a estrutura conhecida falha que a abertura ou a fresta, que incitará importantes giros e mudanças de perspectiva, se revela. Ainda sobre a falha, Gilpin (2011) lança o seguinte comentário:

\begin{abstract}
O trabalho de Forsythe aqui problematizado apresenta o "fracasso" em manter a verticalidade do balé. Embora coreógrafos contemporâneos empreguem o "erro" de muitas maneiras diferentes, o que é interessante é como exatamente as funcionalidades da falha produzem um novo movimento, novas composições cênicas e espaciais e novas interpretações. (GILPIN, 2011: 115, tradução nossa) ${ }^{104}$
\end{abstract}

O desaparecimento, que de algum modo coincide com o erro, com a falta, diz respeito a instauração de novas condições para o acontecimento cênico. A ideia da representação como construção e manutenção de modelos dá lugar a uma profusão de estruturas sonoras,

\footnotetext{
${ }^{103}$ Texto original: "Lightness is a condition where something happens - an accident, a traumatic event, a failure, a disappearance - outside of the capabilities of some form of notation. These issues can be played out via the work of performance choreographer/director William Forsythe. In Forsythe's work, lightness is a quality that emerges out of failure, dissapearance, and disequilibrium." (Gilpin, 2011:113)

${ }^{104}$ Texto original: "The work of Forsythe at issue here presents the failure to maintain the balletic vertical. Although contemporary choreographers employ failure in many different ways, what is interesting is how exactly failure functions to produce new movement, new scenic and spatial compositions, and new interpretations." (Gilpin, 2011:115)
} 
sensoriais e polifônicas que apresentam características e qualidades presentes na noção de performatividade.

Pode-se dizer, deste modo, que o "erro" comentado por Gilpin coincide, na peça Kammer Kammer, com a atitude de Forsythe de apresentar um trabalho no qual os referenciais conhecidos do balé clássico desaparecem diante de uma profusão de dinâmicas. Aquele que espera assistir a um espetáculo de balé pautado em modelos, gestos e linhas espaciais já conhecidas, se decepciona profundamente. Levando-se em conta que o trabalho foi criado por uma companhia de balé do Estado, uma instituição que supõe a manutenção de estruturas e ordens, o susto pode ser maior ainda.

O "erro" de Forsythe, a apresentação do balé em seu "mal desempenho", gera rachaduras em formas já conhecida e promove a possibilidade de construção de novas imagens, experiências e a revisão de conceitos instituídos. O balé, a dança e os sentidos aparecem percorrendo órbitas impensáveis e inapreensíveis.

Neste contexto, o que Forsythe nos oferece é o contato com uma produção que reformula modos de olhar e fazer. Ele leva em consideração alterações de padrões de observação, relação e atuação, o que coincide com considerações sobre performatividade, teatralidade e com a noção de um teatro pós-dramático, colocada por Hans-Thies Lehmann (2010). Essas noções que tratam das dinâmicas sobre os atos e sobre o modo como observamos e nos relacionamos podem ser visualizadas em considerações de Lehman.

O autor, ao traçar características do teatro no contexto atual, que ele denomina como pós-dramático, no qual as ações já não estão subordinadas aos textos e às estruturas dramáticas, nos apresenta o fenômeno teatral como um evento perceptual. $\mathrm{O}$ teatro surge como acontecimento no qual as ações, criadas por diferentes estratégias, são conduzidas muito mais por dinâmicas vinculadas à percepção do que por estruturas, texto e lógicas narrativas.

Essa demanda sensorial ou perceptual coincide com a instauração de recursos e procedimentos que tendem a provocar toques e cruzamentos entre obra e espectador. Um campo dinâmico é gerado no encontro, no momento em que o olhar do espectador é acionado. As possibilidades do olhar se multiplicam e geram aberturas fundamentais para a construção de novas relações. Forsythe faz o seguinte comentário:

... se você está olhando para algo com muita atenção, se você está tentando observar com muito cuidado porque a coisa está um pouco obscura, você tende a ser um espectador mais atento, e pergunta 'o que nós estamos fazendo?' Estamos ensinando uma estética às pessoas? Não, nós estamos ensinando-lhes sobre a observação, sobre 
ser um espectador. Eu não estou tentando refinar o gosto de ninguém, eu gostaria de fazer as pessoas que assistem dança melhores espectadores de dança. (William Forsythe em VASS-RHEE, 2011:146, tradução nossa) ${ }^{105}$

Em Kammer Kammer o balé se dilui em imagens, textos, narrativas não lineares, ambientes sonoros e lugares que se sobrepõem. Os processos analíticos e de interpretação se transformam em experiências que desafiam os limites e as possibilidades perceptivas dos espectadores. Neste contexto, o balé se torna ambiente afetivo, paisagem e peça multifocal. Talvez seja ainda o balé , mas talvez seja o surgimento de uma outra coisa. Cenas escondidas por detrás de praticáveis, das placas móveis que são manipuladas pelos bailarinos e cenas que enxergamos por frestas e por monitores, geram traços e movimentos que se cruzam. As fendas e as aberturas ativam a imaginação para aquilo que se esconde, para aquilo que se revela, para memórias e referenciais que vagam em cena. Diálogos simultâneos, desorientação, discurso pulverizado, descentralizado. A peça assume aberturas, mesmo que inseridas em uma estrutura bem amarrada e com pontuações bem definidas. Essa movimentação vincula corpo e espaço em uma rede de afetos que entrelaça diferentes agentes e produz espacialidades complexas, heterotopias. O afeto é uma das possibilidades de ligação de pontos dispersos em desenhos transitórios:

$\mathrm{O}$ afeto surge no meio, no entre: nas capacidades de agir e ser afetado. Afetar é um choque ou extrusão de um estado momentâneo ou às vezes mais duradouro da relação assim como a passagem (e a duração da passagem) de forças ou intensidades. Isto é, o afeto é encontrado nessas intensidades que passam corpo a corpo (humanos, não-humanos, parte do corpo, e de outras formas), naquelas ressonâncias que circulam sobre, entre, e às vezes se aderem a corpos e mundos, e nas próprias passagens ou variações entre estas intensidades e as próprias ressonâncias. (SEIGWORTH, Greg e GREGG, Melissa, 2010:1, tradução nossa) ${ }^{106}$

Forsythe parte do corpo e cria mecanismos através dos quais esses corpos se vincularão às interferências ambientais. Ele ganha espaço, apresenta no palco estruturas instáveis, com

\footnotetext{
${ }^{105}$ Texto original: “...if you're looking at something very hard, if you're trying to watch very carefully because it's somewhat obscured, you tend to be a more careful viewer, to ask 'what are we doing there?' Are we teaching people the aesthetics at hand? No, we're teaching them about watching, about being a viewer. I'm not trying to refine someone's taste, I would like to make people who watch dancing better dance viewers." (comentário de Forsythe em 2001, em entrevista, de Julie Copeland, disponível na tese de doutorado "Audio-Visual Stress: Cognitive Approaches to the Perceptual Performativity of William Forsythe and Ensemble", 2011, de Freya Vass-Rhee)

${ }^{106}$ Texto original: "Affect arises in the midst of in- between-ness: in the capacities to act and be acted upon. Affect is an impingement or extrusion of a momentary or sometimes more sustained state of relation as well as the passage (and the duration of passage) of forces or intensities. That is, affect is found in those intensities that pass body to body (human, nonhuman, part-body, and otherwise), in those resonances that circulate about, between, and sometimes stick to bodies and worlds, and in the very passages or variations between these intensities and resonances themselves." Seigworth, Greg and Gregg, Melissa, no livro: The Affect Theory Reader, 2010:1.
} 
centros difusos e dispersa a atenção do centro para as dinâmicas que surgem em diferentes ângulos e posições.

Qualidades e princípios que atravessam o corpo irão reverberar no entorno do mesmo modo que o entorno provocará alterações no corpo. E é nesse fluxo de troca e estímulos que Forsythe assumirá seu interesse por objetos, arquiteturas e ambientes que negociarão com o corpo e provocarão mudanças, tremores na percepção e rearticulações espaciais.

Forsythe experimenta arranjos e relações que já não cabem nos palcos um ano antes da montagem de Kammer Kammer. O trabalho Endless House, de 1999, marca essa mudança de interesse. O trabalho acontece metade no palco da Ópera de Frankfurt e metade em um antigo galpão desativado, o Bockenheimer Depot. Essa proposta evidencia seu interesse por aspectos instalativos que deslocam o público fisicamente de um prédio para o outro no meio da apresentação. Aqui não é apenas o olhar que gira, perambula e encontra novas vias de acesso à composição cênica que é apresentada, o espectador precisa agora viajar de metrô e cruzar estações para a segunda parte do trabalho. No Bockenheimer Depot ele é inserido fisicamente na cena, se aproxima de ações, de objetos, dos dançarinos e transita de um lado para o outro buscando o melhor ângulo ou a melhor posição para montar uma cena que se desmonta, que se desfaz, que aparece e some diante de sua presença.

Escolhi abordar este trabalho por último como modo de dar ênfase à participação física do espectador em suas propostas. Endless House é o trabalho que evidenciará a inclusão do espectador à zona de ação das suas propostas. Este trabalho apresenta ainda condições instalativas que me permitem introduzir as questões que serão abordadas na seção seguinte. 


\section{Endless House ou a casa em expansão}

Endless House é o nome do trabalho de William Forsythe que evidenciará seu interesse por configurações espaciais que alterarão radicalmente as relações entre obra e público. O trabalho provocará ainda questionamentos sobre limites impostos por estruturas e definições espaciais que reduzem o conceito de espaço à noção de lugar ou de funcionalidade. $O$ espaço que supera a ideia de lugar se revela logo no título do trabalho. Endless House, que poderia ser traduzido como casa sem fim, é lugar em expansão, é espaço que avança, que se alastra.

O título coincide com o nome de um projeto arquitetônico do austríaco Frederick Kiesler (1896-1966) ${ }^{107}$ - o Endless House. O projeto, que alarga a noção de casa ou lar e no qual Kiesler trabalhou por quarenta anos sem o finalizar, é de 1958. A ideia de criar um espaço de fusão entre arte e arquitetura e de desvincular a noção de casa de um mecanismo de habitação associado a esquemas sociais e planos metropolitanos, favoreceu o surgimento deste projeto que coloca em questão aberturas e flexibilizações de formas conhecidas. $\mathrm{O}$ modo como Kiesler aborda a arquitetura coincide com a noção de um organismo que se expande, de um sistema que se vincula ao entorno: "Ele via arquitetura como um corpo com

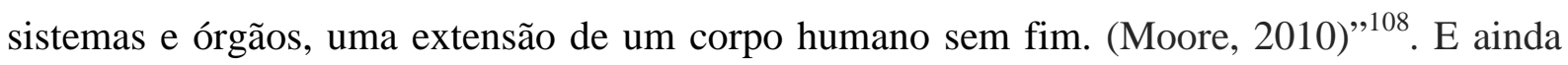
sobre Kiesler:

Ele imaginou a casa como uma forma que fundia arte e arquitetura, iluminação e design de móveis, em um cosmos em miniatura, onde os espaços fluíam naturalmente um no outro e onde a própria vida se torna estetizada. ${ }^{109}$

Richard Schechner (1994) fala ainda sobre um outro projeto de Kiesler, o Endless Theater, que foi criado entre os anos 1916 e 1924. O projeto, que nunca saiu do papel, previa uma nova função para o teatro e tinha espaço para 100.000 pessoas. Schechner apresenta a

\footnotetext{
${ }^{107}$ Steven Valk, dramaturgo da Ópera de Frankfurt entre os anos de 1998 e 2004, afirma que existe uma relação direta deste trabalho com o projeto do arquiteto Frederick Kiesler. Forsythe se inspirou no livro de Kiesler para produzir o Endless House em 1999. (nome do livro).

108 Case Study by Carly Moore, 2010.

Texto disponível no link: https://carlymmoore.files.wordpress.com/2010/12/endless-house-final.pdf. Acesso em agosto de 2015. Texto original: "He saw architecture as a body with systems and organs, an extension of the endless human body."

${ }^{109}$ Texto original: "He imagined the house as a form that fused art and architecture, lighting and furniture design, into a miniature cosmos, where spaces flow naturally into one another and where life itself becomes aestheticized." Matéria da New York Times sobre a exposição Endless House: Intersections of Art and Architecture, que acontece no Museu de arte Moderna de Nova Iorque, no MoMA, entre junho de 2015 e março de 2016. Link: http://www.nytimes.com/2015/08/28/arts/design/review-endless-house-expands-the-definition-ofhome.html?_r=0. Acesso em agosto de 2015.
} 
descrição do Endless Theater feita por Kiesler em 1930.

Toda a estrutura é envolta em capas duplas de aço e vidro opacos soldados. O palco é uma espiral sem fim. Os vários níveis estão ligados com elevadores e plataformas. Arquibancadas, palco e plataformas elevatórias são suspensas e estendidas umas sobre as outras no espaço. A estrutura é um sistema de construção elástico de cabos e plataformas desenvolvidas na construção de pontes. O drama pode se expandir e desenvolver-se livremente no espaço. (KIESLER apud SCHECHNER, 1994:31) ${ }^{110}$

A Endless House de Forsythe é outra. Entretanto, alguns pontos de coincidência justificam o nome de Kiesler nesse contexto. Os traços de uma arquitetura que se abre para o entorno, que se move e incentiva um olhar para o espaço sob um ponto de vista móvel e instável coincide com pressupostos e fundamentos colocados também por Forsythe em seu trabalho.

O autor Steven Spier (2011) percebe no trabalho Endless House uma mudança de interesse de William Forsythe. É a partir desta produção que Forsythe passará a investigar, de modo mais deliberado, espacialidades que não dependem de formatações e limitações que costumam se colocar entre palco e espectador, no contexto do palco italiano. Com esse trabalho ele sugere novas formações espaciais para o balé, para a noção de coreografia e sinaliza o início de um processo de investigação que prevê a observação de princípios da dança em novas articulações e incursões espaciais. A dança salta dos limites do palco, atravessa a rua, cruza a cidade e se posiciona entre bailarinos e espectadores no trabalho Endless House. A público e os bailarinos se aproximam, os corpos se confundem no espaço e é no acionamento de novas dinâmicas e relações espaciais que novos canais de percepção serão solicitados. A transição proposta na estrutura do trabalho, que acontece metade na Ópera de Frankfurt e metade no Bockenheimer Depot, descreve uma trajetória que coincide com alterações fundamentais nas perspectivas e procedimentos que Forsythe passará a investigar no contexto da The Forsythe Company e em projetos nos quais o corpo do espectador é força motriz de suas propostas, como os Objetos Coreográficos. Spier comenta essa mudança de interesse:

Endless House, por exemplo, capta a sua mudança de interesse e a utilização que ele faria do TAT (Theater am Turm) no Bockenheimer Depot. A primeira metade, dirigida por Caspersen, acontece na Opera House e é tanto uma ode quanto elegia ao

\footnotetext{
${ }^{110}$ Texto original: "The whole structure is encased in double schells of steel and opaque weldes glass. The stage is a endeless spiral. The various levels are connected with elevators and platforms. Seating platforms, stage and elevator plataforms are suspended and spanned above each other in space. The structure is an elastic building system of cables and platforms developed from bridge building. The drama can expand and develop freely in space.” (Kiesler apud Schechner, 1994:31)
} 
proscênio do palco, revelada em um tipo de experiência que oferece a literal exposição da sua infra-estrutura. Na segunda metade, o público é deslocado para o Bockenheimer Depot, onde ele é "colocado" à beira ou mesmo dentro do trabalho, que apresenta um grande número de performances simultâneas em diferentes escalas. (Spier, 2011: 146, tradução nossa) ${ }^{111}$

Endless House estreou em Frankfurt no dia 15 de outubro de 1999. O próprio nome do espetáculo, como mencionado acima, coloca em questão aspectos da uma arquitetura que se desfaz, que desenha e apaga o lugar, a casa, o espaço determinado. Casa sem fim, lugar que não é delimitado por paredes, por estruturas fixas, mas que avança, que se constrói em movimento. Esse trabalho marca o início de uma fase de Forsythe na qual aspectos instalativos evidenciam seu interesse pelo espaço, pelos seus desdobramentos e relações com o espectador.

Na Ópera de Frankfurt o espaço do palco, do lugar cênico, é expandido na revelação da estrutura, das vigas e armações que compõem essa espacialidade. Aquilo que na maioria das composições cênicas se esconde é aqui parte de uma paisagem em movimento que insere traços e qualidades do entorno. O espectador no início e no final da apresentação pode espiar o avesso do palco. A arquitetura é exposta e o olhar avança e inclui à área de ação detalhes e elementos do entorno. O palco é desenho borrado que se espalha e se mistura aos mecanismos que se articulam para a montagem e a desmontagem de climas e situações. No Bockenheimer Depot o espectador é imerso em ações e participa da construção de espacialidades que surgem na aproximação com dançarinos e objetos dispostos no local. O espectador, em movimento, passa a fazer parte de ações nas quais se cruzam corpos e objetos que desenham um espaço ativo e voraz de inclusão. Um espaço no qual sujeito e objeto são agentes.

$\mathrm{Na}$ Ópera de Frankfurt, sede do Balé de Frankfurt naquele período, é onde acontece a primeira parte do trabalho. No palco estão dois homens e dois bancos de praça. O fundo do palco é coberto por uma tela que logo no início da apresentação desce lentamente. Ouve-se uma musica oriental enquanto os dois homens estão deitados no chão. Eles se sentam em um dos bancos e repetem o seguinte texto: "não é minha responsabilidade, é sua responsabilidade". Luminárias redondas sobem e descem e acendem e apagam enquanto eles falam. Agora um está sentado e o outro está deitado. As luminárias são como focos de luz. Dezesseis grandes lustres redondos com luzes coloridas se movimentam para cima e para

\footnotetext{
${ }^{111}$ Texto original: "Endless House, for example, captures the shift in his interests and the uses he would make of the TAT (Theater am Turm) at Bockenheimer Depot. The first half, directed by Caspersen, takes place in the Opera House and is both an ode and an elegy to the proscenium stage, revelling in the type of experience it can offer and literally exposing its infrastructure. For the second half the audience relocates to the Bockenheimer Depot, where it mills about at the edge of or within the performance, which has a multitude of concurrent performances of different scales." (Spier, 2011:146)
} 
baixo, sobem e descem e compõem um ambiente no qual som, música e vozes criam uma coreografia de objetos. A cena evolui até que a imagem do palco volte a ser composta por dois bancos num espaço que nos revela a arquitetura do prédio onde o espetáculo é encenado. O espaço se move, se desdobra, expõe aquilo que não vemos com frequência, deixa à mostra as vigas, os suportes que sustentam máquinas, as barras de ferro, as estruturas de aço e todo o aparato implicado na construção do palco e do espaço cênico. O palco despido de ornamentos e cortinas revela sua estrutura, seus maquinários e revela aos espectadores a máquina que se esconde por detrás daquilo que é exposto ao público.

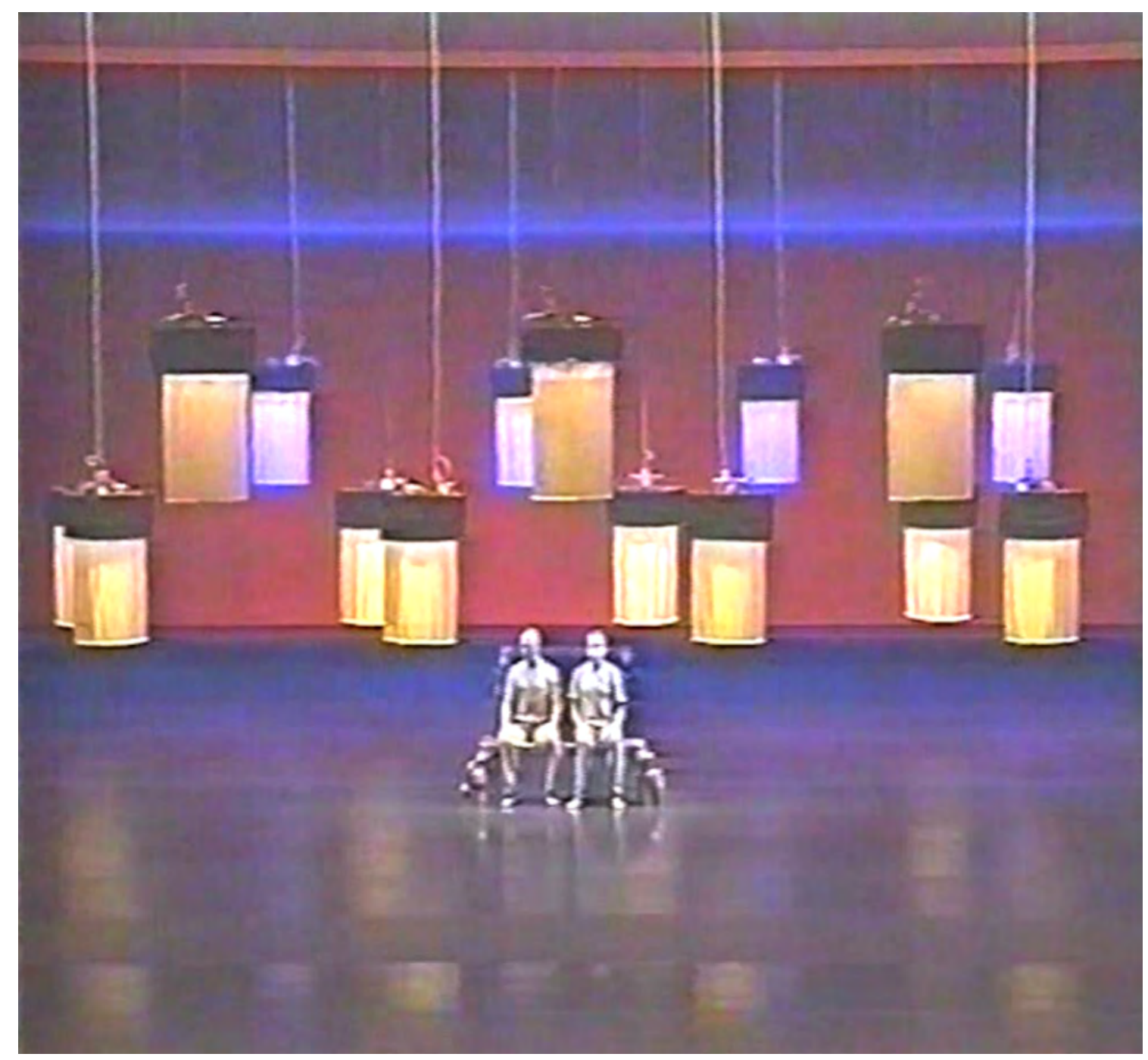

Endless House parte 1 


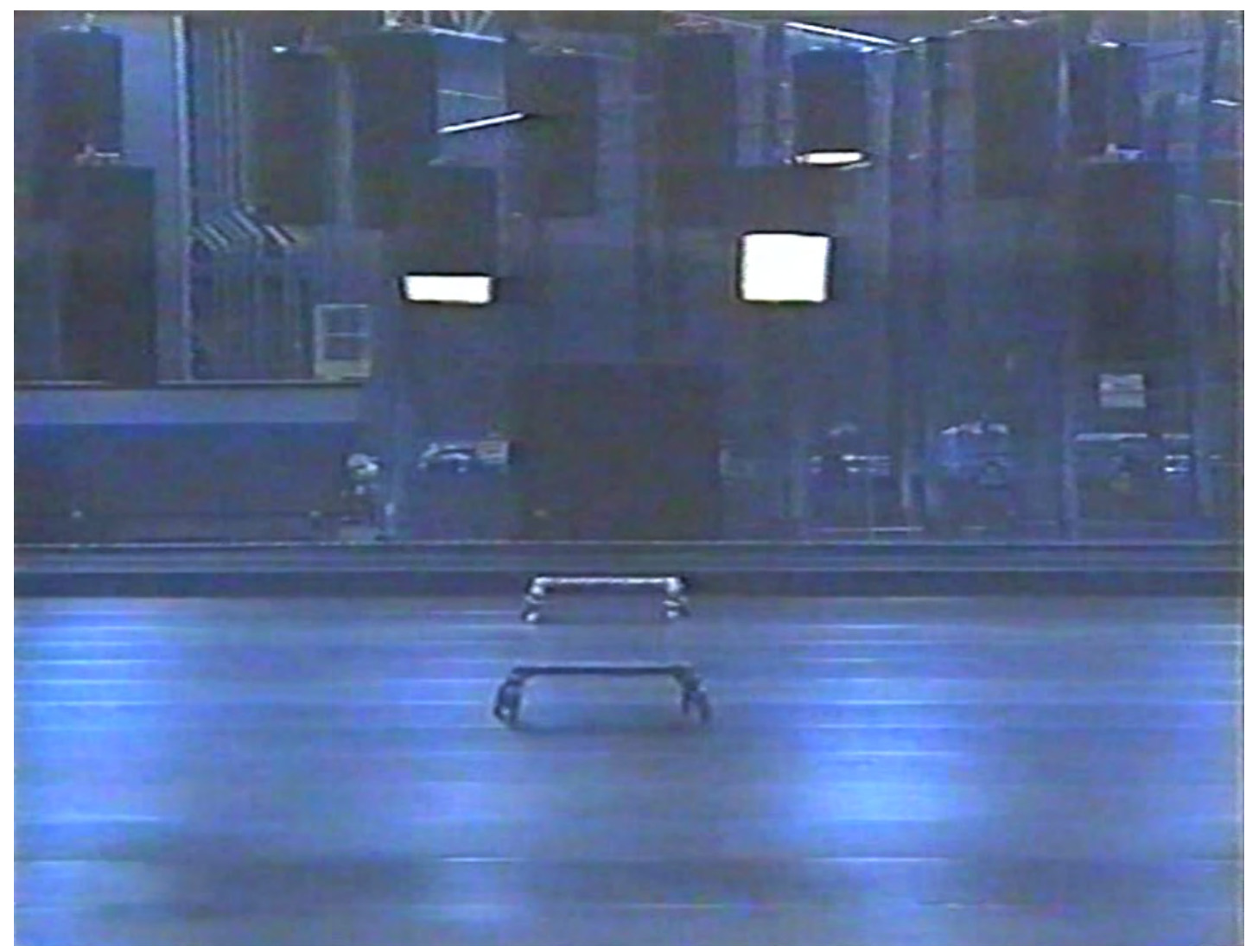

Endless House parte 1

Nesta primeira parte da apresentação, dirigida por Dana Caspersen, William Forsythe e Ron Thornhill dividem o palco. São eles os homens que interagem nas proximidades dos bancos dispostos no palco.

No jornal Berliner Zeitung ${ }^{112}$, Michaela Schlagenwerth, descreve detalhes do trabalho e enfatiza a presença da música na composição de um cenário em movimento onde se cruzam frases que reproduzem parte do discurso do julgamento de Charles Manson, figura polêmica que cometeu inúmeros crimes nos Estados Unidos, fundou uma comunidade alternativa e promoveu discussões controversas nos anos sessenta.

$\mathrm{Na}$ segunda parte do trabalho os espectadores são convidados a se deslocarem até o Bockenheimer Depot, um antigo depósito de trem que era sede da TAT (Theatre am Turm) naquele ano. $\mathrm{O}$ trajeto prevê um deslocamento entre quatro estações de metrô. É preciso pegar a linha U4 na Willy-Brandt-Platz, onde fica a Ópera de Frankfurt, e seguir até a estação final Bockenheimer Warte, onde está o Bockenheimer Depot.

\footnotetext{
${ }^{112}$ Link: http://www.berliner-zeitung.de/archiv/drogen--pop--sex--rausch-mit-charles-manson-und-sharon-tate-william-forsythes--endless-house--helter-skelter,10810590,9723408.html. Publicado em 19.10.1999. Acesso em julho de 2014.
} 


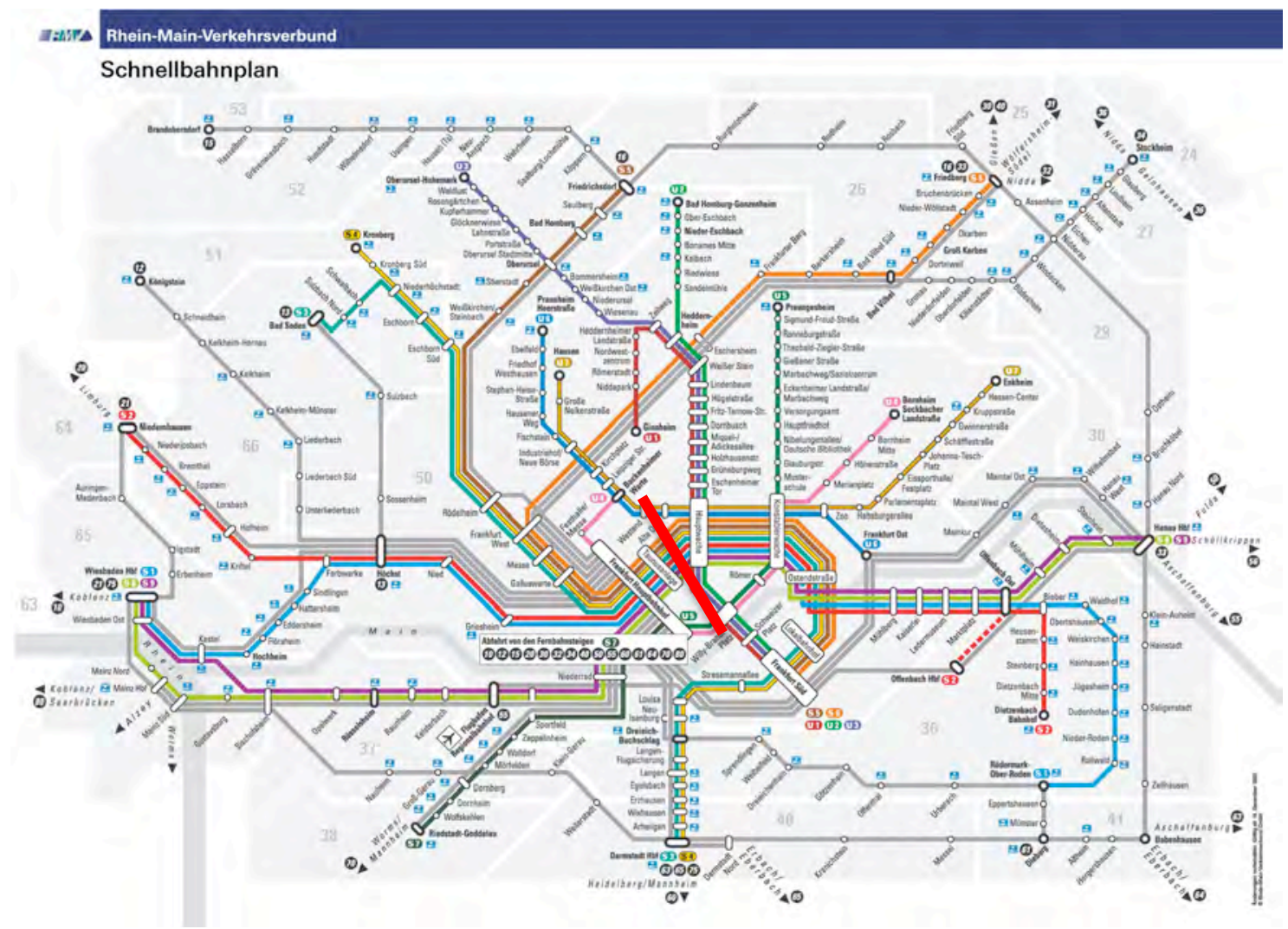

Trajeto de metrô destacado em vermelho

No Bockenheimer Depot os artistas se alongam entre o público que começa a chegar. Artistas dançam e falam enquanto o público se aproxima. Uma bailarina fala ao telefone com alguém insinuando fricções e variações entre o real e o ficcional. Os dançarinos se aquecem. Cadeiras estão espalhadas e os bailarinos dançam e exploram diferentes possibilidades espaciais. Múltiplos focos e ações dividem e confundem a atenção dos espectadores que estão aqui imersos ou, pelo menos, muito próximos das ações dos bailarinos.

Já na entrada os vinte e oito dançarinos estão em ação, se aquecem, ensaiam sequências de movimento ou falas. A maioria dos espectadores tentam primeiramente pegar lugares com o melhor campo de visão possível. Mas, com o início da peça percebe-se que não há nenhuma posição no espaço onde todas as ações possam ser vistas. A peça acontece de modo que nem todos os eventos são perceptíveis. (EVERT, 2003:142, tradução nossa) ${ }^{113}$

Endless House é uma composição de impressões, memórias, figuras, textos, músicas, vestígios e presenças que abordam aspectos contraditórios, ambíguos e conflituosos que

\footnotetext{
113 Texto original: "Bereits mit den Einlass sind die 28 Tänzer in Aktion, wärmen sich auf, probieren Bewegunssequenzen oder Sprechszechen. Die meinsten Zuschauer versuchen zunächst, Plätze mit einem möglichst guten Sichtfeld einzunehmen. Doch mit Beginn des Stückes stellt sich heraus, dass es keine Position im Raum gibt, von der aus alle Vorgänge eingesehen und beobachtet werden können. Das Stück ist so angelegt, das nicht alle Ereigniss wahrnehmbar sind."
} 
atravessam os pensamentos e as ações humanas. As contradições aparecem entre sutilizas, violências e horrores que formam os cenários e os mares por onde transitam as questões abordadas pelo trabalho.

O interesse pelo espectador e pelo reposicionamento não só do seu olhar, como do seu corpo e de sua fisicalidade em ações e trajetos que solicitam um deslocamento pela cidade em uma viagem de metrô, confirmam uma virada decisiva nas abordagens e práticas de Forsythe a partir do trabalho Endless House, de 1999.

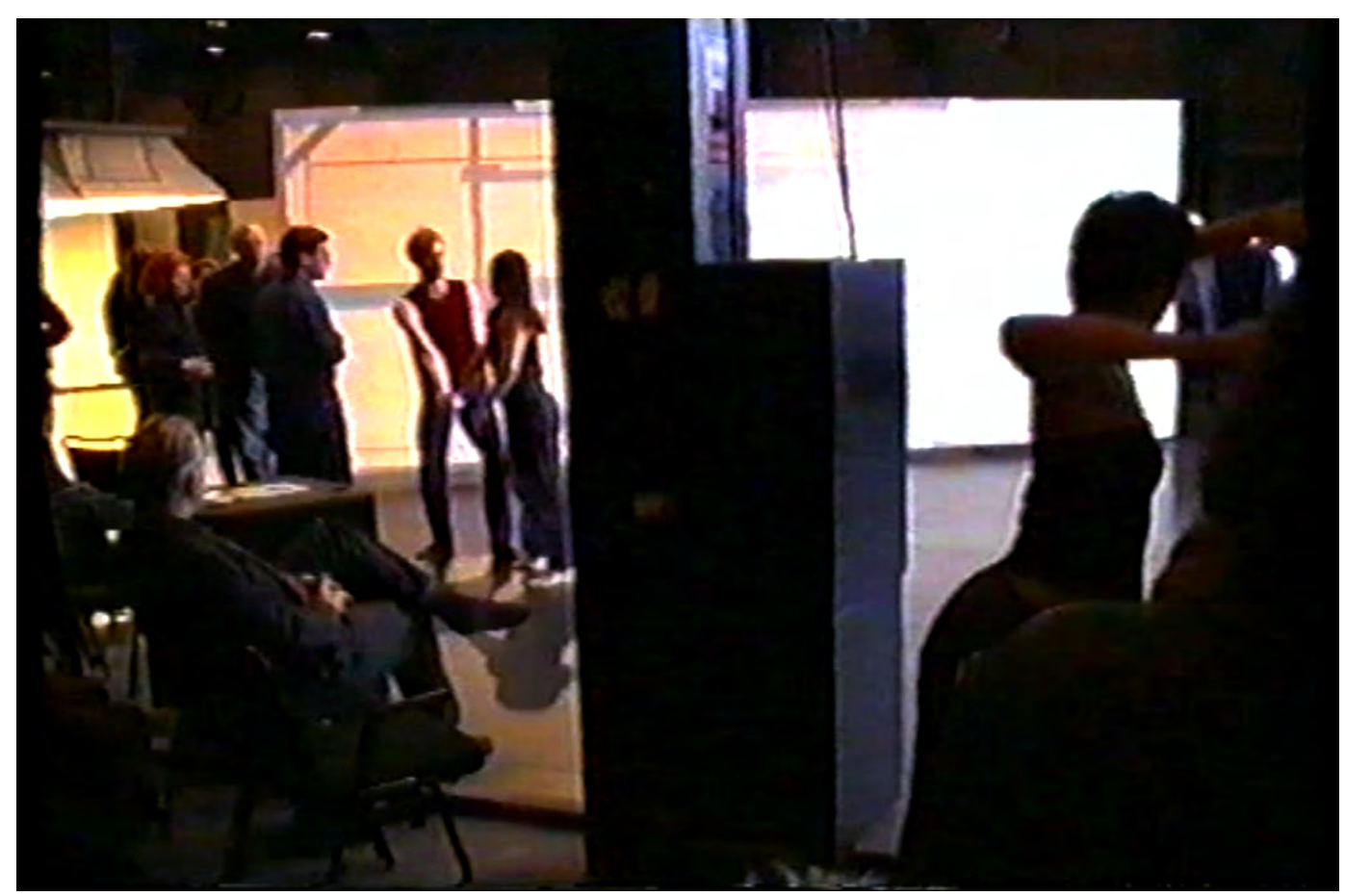

Endless House parte 2

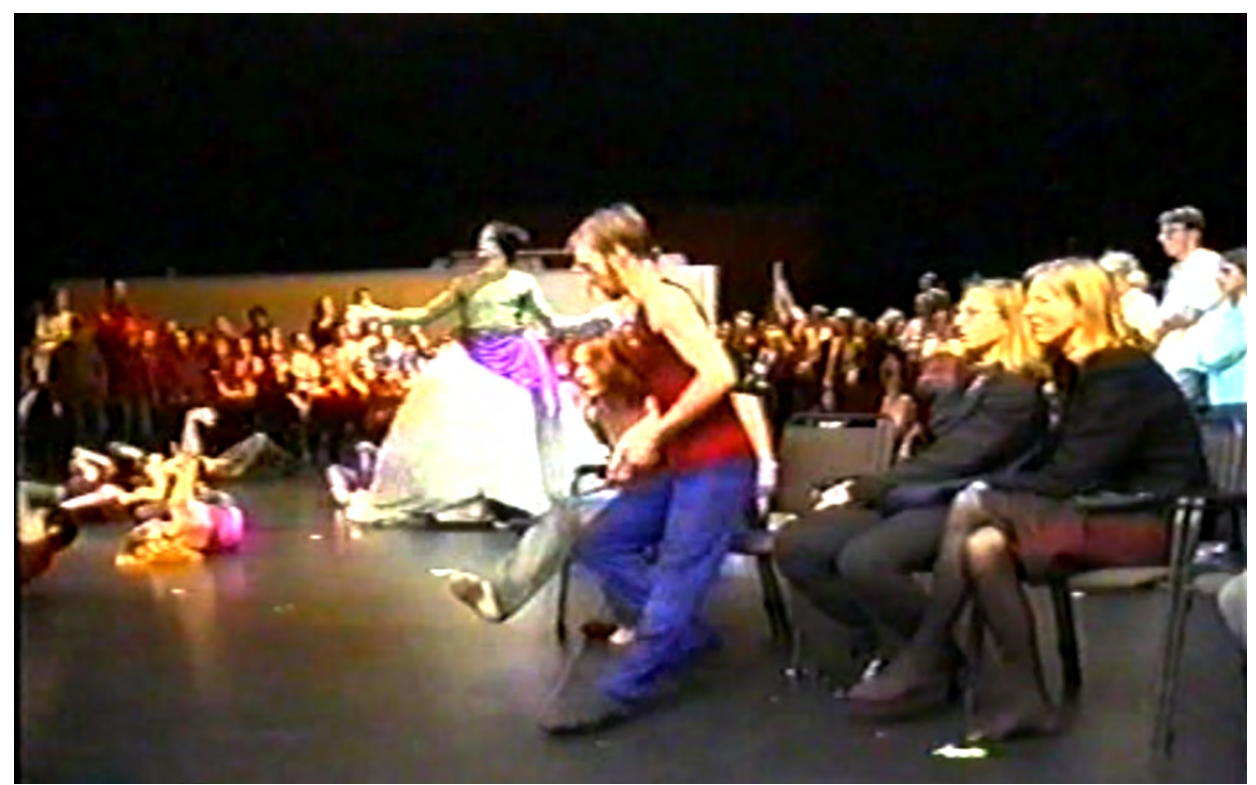

Endless House parte 2 


\section{Mudanças de lugar}

No ano de 1999, com Endless House, um caráter instalativo e experimental irá se impor em suas produções e promoverá rearticulações espaciais que alterarão definitivamente as perspectivas do corpo e do espaço. A prática do balé, do início de sua formação e carreira, mantém-se apenas como orientação, como estrutura que auxilia na construção de pensamentos coreográficos migratórios. A produção e análise do movimento tornam-se seus principais focos de interesse e se desdobram nas mais variadas ações e experimentos.

O que eu chamo aqui de condição instalativa é uma disposição espacial que prevê mudanças constantes de perspectiva e observação. Essa abordagem age na dissolução de bordas que impõem funções e separam a ação artística de seu entorno. O corpo e a percepção se manifestam em zonas indeterminadas e difusas nas quais os arranjos espaciais se encontram em processo de construção e desmontagem. Formação e desaparecimento são ações de um mesmo evento.

Essas características aparecem nas propostas de Forsythe logo em seus primeiros trabalhos, nos quais ele explora variações e desarticulações dos eixos do balé clássico. Entretanto, é o trabalho Endless House que evidenciará seu interesse por formações espaciais que extrapolam os limites cênicos e alteram a distância entre obra e espectador colocada pela configuração da caixa preta. É interessante mencionar ainda que é neste ano de 1999 que Forsythe criará, em parceria com Dana Caspersen ${ }^{114}$, o objeto coreográfico White Bouncy Castle.

A estreia de Endless House coincide ainda com a ameaça de fechamento do Balé de Frankfurt e com o início de sua atuação no Bockenheimer Depot, espaço onde Forsythe desenvolverá projetos mais experimentais e já desvinculados de compromissos com o universo do balé, que de algum modo fazia parte das expectativas e do contexto da companhia do Estado - o Balé de Frankfurt.

Os aspectos instalativos identificados em suas produções passam a ocupar uma posição de destaque na transição do Balé de Frankfurt para a The Forsythe Company. Seus projetos, cada vez mais experimentais, sinalizam seu interesse por questões espaciais que ele investigará em trabalhos e parcerias que acontecerão tanto no contexto dos Objetos Coreográficos, quando em produções junto à The Forsythe Company e em iniciativas que

\footnotetext{
${ }^{114}$ Bailarina que trabalha com Forsythe desde o Balé de Frankfurt e é sua segunda e atual esposa. Dana Caspersen trabalha com Forsythe desde 1988. Carpensen atuou como figura central de diferentes trabalhos de Forsythe tanto no contexto do Ballet de Frankfurt quanto na The Forsythe Company.
} 
destacarão aspectos da arquitetura e das relações institucionais que se colocam entre ação artística e normas pautadas pelas instituições de arte. As dinâmicas e ações que rearticulam o olhar e os sentidos aparecem como principais pontos de interesse e investigação do coreógrafo.

Em Kammer Kammer, por exemplo, a velocidade que surge na costura de cenas e nos intervalos entre uma ação e outra age na fragmentação, na descentralização do olhar e solicita do espectador um estado de atenção ativo no qual os olhos percorrem cantos e dobras escondidas entre as câmeras, entre os lugares que surgem e se escondem entre os praticáveis.

No trabalho Heterotopia princípios e incursões ambientais fazem emergir corpos ambulantes que geram e apagam limites e bordas enquanto interagem com o entorno.

Endless House pressiona as margens do teatro, se espalha pelas ruas de Frankfurt e direciona o público ao Bockenheimer Depot. Como o que acontece na pintura não se aplica somente à pintura, o que vemos na produção de Forsythe é uma pressão sobre a margem, o momento em que o trabalho se espalha e adianta um período de trânsitos e negociações com limites institucionais que virá a seguir. Ao mesmo tempo em que o trabalho se expande novas relações com o espectador passam a ser investigadas. A presença do espectador passa a ganhar destaque no encontro e na fusão entre aquilo que se convencionou chamar obra e espectador.

Esse trabalho explode o lugar do proscênio, avança pela estação de metrô de Frankfurt e pode ser observado a partir de um fenômeno análogo que acontece nas artes visuais e que espalha o lugar da pintura para além dos limites da tela.

Nesta abordagem coreográfica, na qual estão explícitas relações e ativações, o espectador ganhará mais espaço e passará a ser agente fundamental em um processo performativo que prevê a movimentação como ato que se manifesta e se produz no mundo. Essas novas perspectivas de análise da noção de dança e coreografia se manifestam também em ações que desafiam limites institucionais. 


\section{Lugares em Construção}

Lugares de abraçar,

lugares para passar.

Passagens.

Instalar

Montar, desmontar, produzir texturas, intensidades, alturas e oscilações. 
Apresento a seguir um olhar sobre condições presentes em projetos de William Forsythe que evidenciam seu interesse por problemáticas e articulações espaciais ao mesmo tempo em que colocam em questão aspectos e limites institucionais. Lugares que se dissolvem, estruturas ambientais e arquiteturas articuláveis que propõem novos pactos e zonas de ação para a produção de arte.

A imersão por lugares que são gerados em processo e que negociam com regras e modelos impostos por instituições é um dos principais pontos de discussão desta seção. A noção de instituição será abordada aqui sob o ponto de vista do consenso, das definições circulares que se pautam e se repetem em regras e postulados aceitos coletivamente. Mais do que lugares estáveis e reguladores de modelos institucionais que podem ser observados na estrutura de escolas, teatros e museus, por exemplo, o termo instituição é empregado aqui como organização que se fundamenta na regulamentação de ordens e sistemas que agem reprimindo dissensos, rupturas inesperadas e movimentos aleatórios em diferentes contextos.

O conceito de Heterotopia, abordado na seção anterior, define propriedades, dispersões e choques espaciais que despertam o interesse de Forsythe ainda como diretor e coreógrafo de peças e composições cênicas que são apresentadas a um público, que mesmo bastante próximo do evento, não é ainda protagonista de suas proposições. É no cruzamento de lugares que Forsythe experimentará novas condições para o espectador e apresentará trabalhos que se colocam entre noções como artes visuais, dança, coreografia e arquitetura. Suas propostas pautadas em aspectos instalativos e dinâmicos desenham e apagam ambientes. Elas aparecem principalmente na série de Objetos Coreográficos. Essas produções destacam a presença do espectador em composições mais livres e desvinculadas das condições que se colocam em uma apresentação com hora e local marcado.

O objetivo aqui é dar ênfase a problemáticas que redefinem limites entre arte e instituição. De que modo Forsythe propõe uma reformulação do lugar da dança ou mesmo da arte? E quando a dança já não está condicionada a lugares regulados por modelos e padrões instituídos? E o que acontece quando a dança acontece no susto, na surpresa do corpo diante de reformulações espaciais? Forsythe comenta:

Penso que a dança não é dependente de nenhuma instituição. Mesmo que amanhã você feche todos os teatros do mundo, ainda assim haverá sempre dança de vários tipos para toda a humanidade. (FORSYTHE, 2004:6 em "Ballettanz, das Jahrbuch", tradução nossa) $)^{115}$

\footnotetext{
${ }^{115}$ Texto original: "Ich glaube, dass Tanz in keiner Weise von Institutionen abhängt. Selbst wenn Sie morgen alle Theater der Welt schliessen, gabe es immer noch genug Tanz der unterschiedlichsten Art für die gesamte
} 
Ao propor o trabalho Endless House, ou "casa sem um fim determinado", Forsythe alarga limites institucionais. A instituição como casa, como lugar seguro e destinado a uma função determinada e utilitária entra em crise. A casa que Forsythe propõe atravessa os limites que orientam a estabilidade do lugar. Sua casa é demolição de lugar seguro, é aquilo que se alonga, que cruza a cidade, é ato de caminhar e transitar entre lugares. E é deste modo que ele enfrenta e problematiza seus vínculos institucionais tanto com a instituição Balé de Frankfurt quanto com as instituições balé, coreografia e arte.

Essa observação diz respeito ainda a enfrentamentos das artes com a instituição em diferentes situações. Tanto no teatro quando nas artes visuais, a instituição aparece muitas vezes vinculada à ideia da casa, do lugar que acolhe e prevê organizações que são regidas por regras e regulamentações que determinam modelos estéticos e mercadológicos. Quando a casa que acolhe se abre para condições menos seguras e estáveis, propostas e condições experimentais tendem a desarticular as decorações e os modelos que acostumam o olhar para relações previsíveis. Nikolaus Hirsch comenta essa analogia da casa com o lugar estável a partir de considerações sobre o "cubo branco", nas artes visuais, e a "caixa preta" no teatro:

\begin{abstract}
Análogo ao "cubo branco" das artes visuais, a "caixa preta" do teatro é um paradigma arquitetônico que se constrói para o controle total: é um espaço neutro autônomo, e estável, com luz e um clima estável. Ao contrário dos museus de arte moderna, o "Teatro Municipal" tradicional é uma "casa estável" com uma estrutura social segura que normalmente tem um grupo permanente empregado e técnicos de palco sindicalizados". ( HIRSCH, 2007: 65, tradução nossa) ${ }^{116}$
\end{abstract}

Hirsch (2007) pontua diferenças e localiza os museus de arte moderna como lugares menos seguros, sob o ponto de vista das regulamentações, ideia que pode ser problematizada tendo em vista os mecanismos mercadológicos que se impõem nessas instituições e geram campos seguros para o evento da arte. Entretanto, as práticas nesses espaços museológicos, se comparadas àquelas que povoam casas de teatros mais convencionais, tendem a ser mais flexíveis e experimentais. Vale à pena lembrar ainda que a estrutura que o autor destaca como exemplo da caixa preta é pautada em referenciais, sobretudo, europeus, onde os teatros municipais e estaduais contam com equipes e grupos de artistas contratados como funcionários da casa. Situação esta que pode ser muito distinta em diferentes continentes,

Menschheit." William Forsythe ( ballettanz, das Jahrbuch, 2004:6)

116 Texto original: "Analogous to the "White cube" of visual art, the "black box" of the performing arts is an architectural paradigma that is constructed for total control: it is an autonomous, neutral, stable space with even light and a steady climate. Unlike the museums of modern art, the classic "city theater" is a "stable house" with a basically secure social structure that usually includes a permanently employed ensemble and unionized stage technicians". (Hirsch, 2007: 65) 
onde as organizações teatrais seguem outras lógicas.

\title{
Pressão sobre as margens
}

Brian O' Doherty (2002), no livro No Interior do Cubo Branco ${ }^{117}$, tece importantes considerações sobre o espaço da arte, problemáticas institucionais e transformações que alteram as perspectivas espaciais do Cubo Branco $^{118}$ a partir de uma análise sobre o espaço de exposição das galerias modernistas. O isolamento dos trabalhos de arte, neste contexto, é interpretado por O' Doherty como a reprodução de ambientes nos quais as convenções definem regras e isolam os trabalhos das interferências do mundo.

\begin{abstract}
A galeria ideal subtrai da obra de arte todos os indícios que interfiram no fato de que ela é "arte". A obra é isolada de tudo o que possa prejudicar sua apreciação de si mesma. Isso dá ao recinto uma presença característica de outros espaços onde as convenções são preservadas pela repetição de um sistema fechado de valores. Um pouco da santidade da igreja, da formalidade do tribunal, da mística do laboratórios de experimentos junta-se a um projeto chique para produzir uma câmara de estética única. Dentro dessa câmara, os campos de força da percepção são tão fortes que, ao deixá-la, a arte pode mergulhar na secularidade. (O’ Doherty. 2002: 3)
\end{abstract}

O’Doherty fala sobre a pressão sobre a margem, a importância do Impressionismo nesse processo gradual de assimilação e superação da moldura e aborda também a ideia da pintura como objeto isolado do entorno na seguinte consideração:

\begin{abstract}
Uma marca do Impressionismo é o modo como o tema, escolhido espontaneamente, atenua a função estrutural da borda num ponto em que a margem se encontra pressionada pela crescente falta de profundidade do espaço. Essa pressão duplicada e bem contrária sobre a margem é o prenúncio da definição da pintura como um objeto auto-suficiente - um receptáculo de um fato ilusório agora se torna o próprio fato primário -, o que nos coloca na direção certa de um clímax estético arrebatador. (O’ DOHERTY, 2002:13)
\end{abstract}

Os movimentos que acontecem na própria área da tela, ou da representação, reorientam, aos poucos, o olhar e o acontecimento para zonas instáveis que surgem nas relações possíveis da obra com o entorno. As expansões laterais da tela, como essas apontadas no contexto do Impressionismo, seguem adiante e ganham força nas pinturas expressionistas. O’Doherty (2002) afirma:

\footnotetext{
${ }^{117}$ Livro que apresenta quatro ensaios de O’Doherty que foram inicialmente publicados na revista Art Fórum nos anos 70 e 80.

${ }^{118}$ Cubo branco se refere aqui ao espaço ideal, neutro e isento de interferências onde a obra modernista poderia ser apresentada ao público.
} 
As pinturas expressionistas abstratas seguiram o caminho da expansão lateral, dispensaram a moldura e gradativamente passaram a conceber a borda como a unidade estrutural por meio da qual a pintura começava a dialogar com a parede por trás." (O’ DOHERTY, 2002:21)

E é neste processo de expansão e de rearticulação de concepções espaciais que a área da tela como espaço fechado de representação se transforma em uma superfície ativa. O’Doherty (2002:32) afirma ainda que "essa superfície reage como um campo a qualquer marca sobre ela."

Os registros ilusionistas se diluem na tinta, na matéria que virou sujeito da pintura. A superfície pictórica se apresenta agora como diálogo intenso de forças estéticas que assumem o espaço da tela como campo gerador de sentidos e materialidades que escapam das molduras.

A neutralidade do Cubo branco é ameaçada pelo potencial da matéria e das forças que saltam das telas e das esculturas. As linhas dos quadros se estendem tocando a arquitetura e gerando espaços que surgem da relação e intersecção de forças que apontam para múltiplas direções.

E é deste modo que propostas artísticas e curatoriais redesenham o espaço, lançam o olhar para além dos limites da obra, criam espaços para a habitação do corpo, redefinem normas e limites institucionais.

Ao desafiarem limites institucionais Marcel Duchamp (1887 - 1968) e Kurt Schwitters (1887 - 1948), por exemplo, redefinem parâmetros para os trabalhos de arte e para o espectador. Sua propostas estimulam a produção de estruturas complexas que reorganizam constantemente os pactos entre arte e instituição ao mesmo tempo em que desafiam a percepção para novos acessos espaciais.

Marcel Duchamp, um dos expoentes das artes no século XX, redefiniu limites de noções e conceitos de obra de arte, foi curador de exposições surrealistas entre 1938 e 1942, em Nova Iorque, e criou espaços ou ambientes por onde o público circulava e era convidado a participar de experiências sensoriais. Em 1938, na exposição 1.200 sacos de carvão, Duchamp cobriu o teto da sala de exposição com sacos de carvão. $O$ teto se desloca, ganha volume e profundidade. Enquanto o espectador caminha pelo espaço expositivo uma fuligem proveniente desses sacos cai sobre as suas cabeças e roupas. O ambiente limpo, neutro e passivo da galeria surge aqui como um lugar ativo que provoca o olhar e o deslocamento do corpo do espectador.

Na exposição First Papers of Surrealism, realizada em 1942, na Whitelaw Reid Mansion, inúmeras linhas foram colocadas no espaço expositivo, de modo que o espectador 
precisava cruzar os emaranhados para conseguir se aproximar dos quadros. Novos elementos transformam os ambientes expositivos em espaços interativos nos quais a percepção dos espectadores é alterada e novas relações são produzidas.

Há de se mencionar ainda, no que diz respeito a ativação do espaço e a transformação deste lugar em ambiente, a atuação de Kurt Schwitters. O artista, conhecido pelo trabalho Merzbau, antecipa a construção daquilo que será conhecido como Environment. "O Environment era um gênero que só apareceria quarenta anos depois, e a ideia de um espectador rodeado ainda não existia" (O’Doherty, 2002: 43). Entretanto, estão lançados ali os princípios que mudariam de uma vez por todas as perspectivas espaciais e temporais do espaço expositivo.

Merzbau era uma obra mais forte e sinistra do que aparentam as fotografias que dispomos. Nasceu em um ateliê - quer dizer, um recinto, materiais, um artista e um processo. Espaço ampliado (escada acima e abaixo) e efeito do tempo (por cerca de treze anos). Não se pode pensar na obra como estática, como aparece nas fotografias. Composta por metros e anos, era uma estrutura mutante, polifônica, com múltiplos motivos, funções, conceitos de espaço e de arte. (O’Doherty, 2002:44)

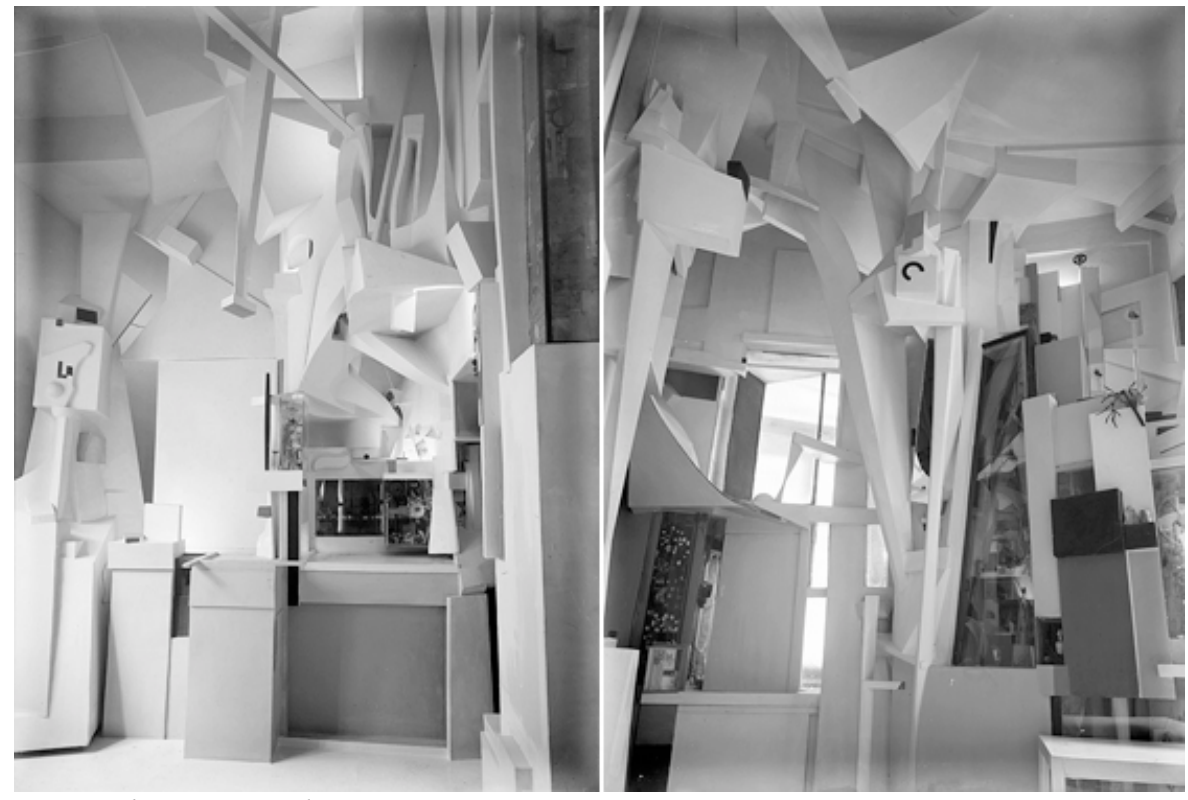

Merzbau, Kurt Schwitters

O’Doherty, ao fazer ainda considerações sobre o trabalho Merzbau, diz que este "talvez seja o primeiro exemplo de uma "galeria" como câmara de transformação, a partir da qual o mundo pode ser colonizado pelo olho convertido.”(O’Doherty, 2002:46)

Esse lugar dinâmico no qual o olho do espectador penetra a superfície do trabalho e trafega por materialidades que se vinculam ao seu corpo, apresenta traços de uma composição espacial que será amplamente investigada e experimentada por práticas e procedimentos 
artístico ao longo do século XX até os dias atuais.

Essas dinâmicas aparecerão em noções como a de instalação, que destacarei a seguir no contexto de uma parceria de Forsythe com o arquiteto Nikolaus Hirsch.

\section{Ocupação Bockenheimer}

A noção de instalação como princípio orientador das investigações espaciais no contexto do projeto de Forsythe desenvolvido em parceira com o arquiteto Nikolaus Hirsch no Bockenheimer Depot diz respeito a construção de uma arquitetura frágil, porosa e em constante processo de criação.

Instalar uma situação, desdobrar o espaço, manejar, organizar, desmontar e rearticular, escorregar, pendurar, sentar, deitar e levantar, atravessar, deslizar e parar são ações que decorrem de ocupações que vinculam relações e escolhas. Os vetores que acionam a percepção potencializam o surgimento de ambientes instalativos, lugares que alteram referenciais, que aceleram ou desaceleram o tempo, modificam o peso e as perspectivas de um olhar que já não está centrado na visão. O corpo age e reage ao ambiente, o corpo dilui-se na paisagem. Orientações e desorientações espaciais provocam movimentos e escolhas que levam o corpo, muitas vezes, para lugares pouco prováveis. No momento em que perde seu referencial, o corpo gira enquanto procura novos pontos de apoio. A perda do chão ou o grito do olhar ao se deparar com o desconhecido aciona um processo intenso no qual a velocidade do susto evita que as escolhas sejam resultados de processos analíticos e intelectuais. As forças que puxam, suspendem e lançam a percepção para uma rede de novas sinapses oferecem condições para que os sentidos selecionem, mapeiem e descubram trajetos.

Levando-se em consideração a criação de espaço sob o ponto de vista do movimento e dos resíduos presentes nas curvas e declives da percepção, é possível verificar o surgimento de um pensamento que experimenta trajetos não lineares e que assim mapeia novas rotas espaciais. Pode-se ainda considerar que essas forças difusas se manifestam como pensamentos ambulantes que dinamizam relações instalativas.

Nas relações dinâmicas entre corpo e espaço destaco a noção de instalação.

Escolho o termo instalação como noção orientadora de problemáticas, condições transitórias e também como substantivo ou partícula gramatical que se desdobra em verbo de ação indicativo de um ato ou movimento - instalar.

Instalar um espaço implica alterar linhas, pontos de apoio, dinamizar estruturas e é neste 
movimento que são propostas novas relações entre corpo e espaço.

O termo instalação coincide com o momento em que o ponto de fuga abandona uma posição estável e percorre diferentes trajetos. Instalação é um conceito amplo e mutante que provoca a redefinição constante de sua própria noção assim como favorece o surgimento de novos parâmetros e pontos de vista para a reflexão e conceitualização do fenômeno artístico.

Os trajetos e a relação entre diferentes elementos costumam compor os ambientes propostos pelas instalações. De acordo com a Enciclopédia do Itaú Cultural ${ }^{119}$, o termo que foi incorporado ao vocabulário das artes visuais na década de 1960 se refere às colagens e aos ambientes construídos, principalmente, em espaços de galerias e museus.

\begin{abstract}
A instalação arte difere, pois, da mídia tradicional (escultura, pintura, fotografia, vídeo) ao abordar o espectador diretamente como uma presença literal no espaço. Mais do que imaginar o espectador como um par de olhos sem corpo que observa o trabalho à distância, a instalação arte pressupõe um espectador (encarnado) cujos sentidos de tato, olfato e audição são intensificados assim como o seu sentido visual. (BISHOP, 2005: 6, tradução nossa) ${ }^{120}$
\end{abstract}

Cores, peças, objetos, materiais e sons são alguns dos componentes desses trabalhos de arte que ao problematizarem limites, como o espaço do espectador e o espaço do trabalho, se lançam ao desafio de questionar noções e conceitos que limitam e definem o campo de ação da arte. Enquanto contornos se diluem o corpo investiga, tateia e produz espaços. E é na dinamização dos corpos e dos espaços que surge o terreno híbrido e complexo da arte da instalação.

O conceito de instalação surge na redefinição e na flexibilização do acontecimento artístico. As décadas de 50 e 60, sobretudo, sinalizaram importantes questões práticas e teóricas que atravessaram o século XX e se colocam hoje, no século XXI, como condições fundamentais de práticas e teorias sobre o fenômeno de arte. Neste contexto, destaco a condição instalativa ou mesmo o amplo campo de ação da instalação, que foi intensamente investigado, principalmente em meados do século XX, para pensar a multiplicidade de eventos, experimentações e diálogo entre campos e linguagens na arte contemporânea. $\mathrm{O}$ foco desta abordagem não se dirige à instalação como categoria ou gênero, mas como estrutura disparadora de ações que borram os limites entre conceitos, espaços e ações em um

${ }^{119}$ Disponível no link:

http://www.itaucultural.org.br/aplicExternas/enciclopedia_ic/index.cfm?fuseaction=termos_texto\&cd_verbete=3 648. Acesso em: 02.03.2014

${ }^{120}$ Texto original: "Installation art therefore differs from traditional media (sculpture, painting, photography, vídeo) in that it addresses the viewer directly as a literal presence in the space. Rather than imagining the viewer as a pair of disembodied eyes that survey the work from a distance, installation art presupposes an embodied viewer whose senses of touch, smell and sound are heightened as their sense of vision.” (Bishop, 2005:6) 
movimento de superação de dicotomias que fundamentaram ontologicamente a filosofia moderna, com a distinção entre sujeito e objeto.

Instalação arte é ainda um termo que, assim como ambiental, vem sendo amplamente utilizado no contexto da arte contemporânea para tratar de condições transitórias, de arranjos provisórios que assimilam e dialogam com o entorno. De acordo com a autora Julie H. Reiss (2001):

Antes do termo "instalação arte" tornar-se parte do vernáculo da arte contemporânea, havia o termo "Ambiente", que foi usado por Allan Kaprow, em 1958, para descrever seus trabalhos multimídia (com medidas de um quarto). A crítica apropriou-se deste termo para descrever uma série de trabalhos por duas décadas. Em meados dos anos 1970, o termo "Ambiente", embora ainda popular, se juntou a outros, incluindo "projeto de arte" e simplesmente "arte temporária". (REISS, 2001:6, tradução nossa) ${ }^{121}$

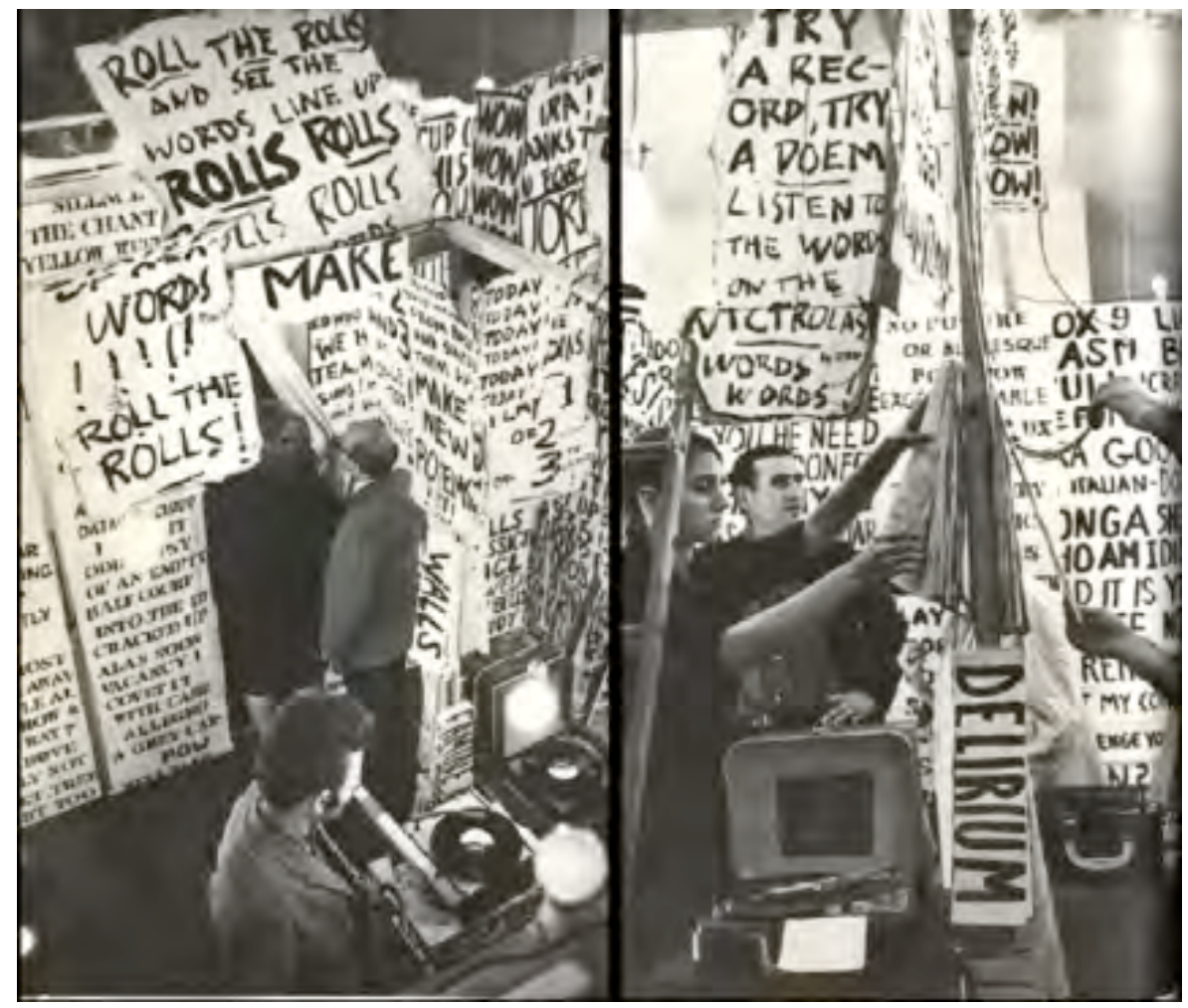

Environment, Kaprow

Mobilidade espacial, abertura da zona de ação cênica e desdobramentos múltiplos do espaço são alguns dos princípios que aparecem no projeto de ocupação do Bockenheimer

\footnotetext{
121 Texto original: "Before the term "Installation art" became part of the vernacular of contemporary art, there was the term "Environment", wich was used by Allan Kaprow in 1958 to describe his room-size multimedia works. This term was picked up by critics and used to describe a range of works for two decades. In the mid1970s, the term "Environment", while still popular, was joined by others, including "project art" and simply "temporary art".” (Reiss, 2001:6). No livro "From Margin to Center, the Spaces os Installation Art".
} 
Depot. Apresentarei a seguir o surgimento dessas qualidades, de estímulos e provocações que reorientam experiências espaciais e promovem encontros acidentais e inusitados em condições desvinculadas dos padrões de relação que, na maioria das vezes, se estabelecem em uma instituição teatral.

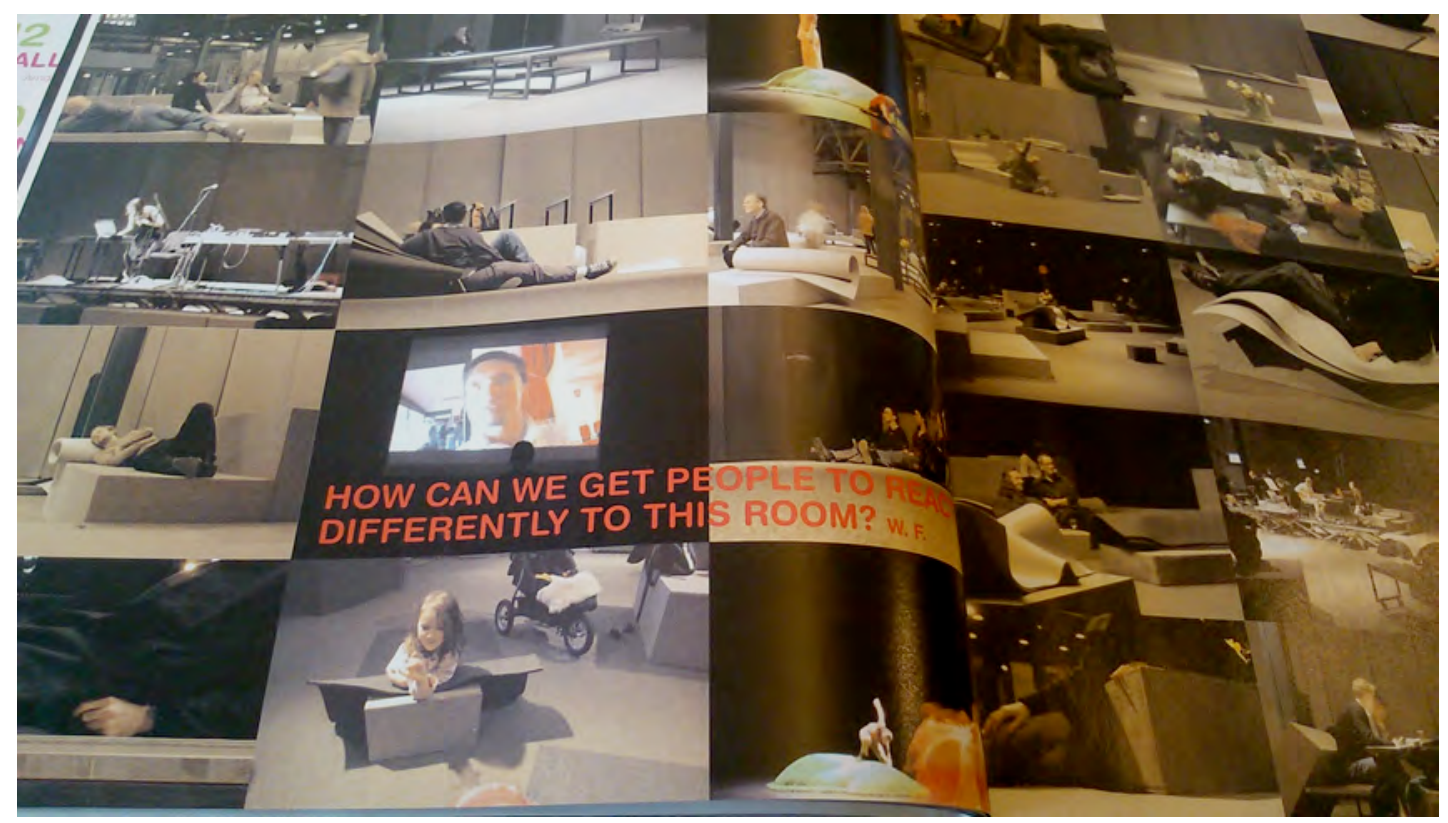

Ocupação do Bockenheimer Depot

O projeto de ocupação do Bockenheimer Depot aconteceu em 2004, ano em que houve o fechamento ${ }^{122}$ do Balé de Frankfurt e do grupo de teatro TAT( Theater am Turm) ${ }^{123}$, e estava inserido no contexto de uma ampla programação de final de temporada ${ }^{124}$ que contou com uma série de apresentações "de teatro, dança, filme e aulas, muitas das quais aconteciam em diferentes lugares da cidade (SPIER, 2011:146)".

O Bockenheimer Depot é um antigo depósito de trem localizado no quarteirão da universidade Johann Wolfgang Goethe, em Frankfurt. O local, sede da companhia TAT, de 1995 a 2004, foi ocupado na ocasião da programação acima com um projeto de instalação de Nikolaus Hirsch ${ }^{125}$ e Forsythe que durou quatro meses. A instalação, montada no interior do Bockenheimer, transformou o espaço em uma área pública e comunitária que podia ser ocupada, sem nenhum custo, das quartas-feiras aos sábados, das $14 \mathrm{~h}$ às $22 \mathrm{~h}$. Entre as questões

\footnotetext{
${ }^{122}$ Problemas orçamentários e dificuldades de relação levaram ao fechamento do Balé de Frankfurt e do grupo TAT (Theater am Turm) neste mesmo ano de 2004.

${ }^{123}$ TAT - Theater am Turm - foi um importante grupo de teatro politicamente engajado que atuou em Frankfurt desde 1953 em diferentes espaços/sedes.

${ }^{124}$ Que era também um protesto em relação ao fechamento do Ballet de Frankfurt.

125 Nikolaus Hirsch é arquiteto, curador, escritor e vive em Frankfurt am Main.
} 
levantadas por esse trabalho, a crítica sobre as relações entre o público e o privado surge como uma das problemáticas fundamentais, assim comentada por Forsythe: "Eu pensei em um espaço onde ninguém estivesse tentando vender alguma coisa ou dizer-lhe quanto tempo você poderia ficar ou como se comportar, onde você não tivesse que gastar nenhum dinheiro" ${ }^{26}$. Spier explica ainda que Forsythe considerava o espaço como um parque com teto ${ }^{127}$ no qual as pessoas podiam levar suas comidas, havia brinquedos para as crianças, uma livraria, jornais e ainda um restaurante take-away. Forsythe explica:

Nós não tínhamos licença para um restaurante então Heiner Blum surgiu com a ideia de garçons com telefones celulares e o menu era uma compilação de todas as coisas disponíveis nos lugares take-away do bairro. Você apenas ligava e o pedido estava lá em 10 minutos. (FORSYTHE em Spier, 2011:47, tradução nossa) ${ }^{128}$

Para acomodar o trânsito de pessoas no interior do Bockenheimer Depot, Forsythe e Hirsch criaram estratégias e lançaram mão de recursos e materiais que transformaram as características e as qualidades daquele lugar. O amplo espaço industrial construído com tijolos e colunas de ferro foi transformando em um ambiente mais caloroso e convidativo à ocupação. Spier pontua que para isso, cortinas de feltro cinza foram estendidas entre o espaço das apresentações e o foyer e todo o chão da área aberta ao público foi coberto com esse mesmo material, o que interferia na acústica e evitava a propagação do som.

Para a ocupação do Bockenheimer, Forsythe e Hirsch projetaram blocos leves e tridimensionais em diferentes formatos, que poderiam ser utilizados como mesa, banco ou apoio para o corpo. Essas estruturas desafiam o corpo à construção de novas relações físicas que implicavam na descoberta de novas possibilidades de movimentação e ocupação. Ao incentivar novas orientações e deslocamentos, Forsythe instaura um pensamento coreográfico que amplia as possibilidades de relação deste corpo com os demais elementos que constituem o ambiente. O corpo é convocado a percursos coreográficos inesperados. E é neste ponto que princípios orientadores de conceitos como dança e coreografia serão confrontados com novas perspectivas de análise. O esgotamento da noção de dança como sinônimo de coreografia e a noção de coreografia como um conjunto estável de movimentos previsíveis e precisos acontece neste instante de oscilação e indeterminação no qual as atualização, falhas e desvios

\footnotetext{
${ }^{126}$ Texto original: "I thought, how about a space where no one was trying to sell you anything or tell you how long you can stay or how to behave, where you don't have to spend any money". (Spier, 2011:146”. Em entrevista a Spier no dia 21 de novembro de 2007.

${ }^{127}$ Idem 127.

${ }^{128}$ Texto original: "We didn't have a permit for a restaurant so Heiner Blum came up with the idea of waiters with mobile phones and the menu was a collection of all things available from all the neighbourhood take-away places. You just called up and it was there in 10 minutes." (William Forsythe em Spier, 2011:47)
} 
de percurso instauram qualidades nos movimentos que ampliam seus conceitos.

O pensamento coreográfico abordado por Forsythe extrapola os limites da dança, do evento cênico e promove variações nas relações que os corpos estabelecem com diferentes estímulos. Mecanismos que induzem o corpo a deslocamentos padronizados são substituídos por dispositivos que convocam o surgimento de novas organizações, relações e temporalidades. Aparatos como cadeiras e mesas desaparecem e no lugar surgem cubos, bolas e estruturas de diferentes formas geométricas que propõem novos trajetos e acomodações para os músculos e para os ossos. Forsythe e Hirsch pontuam: "As pessoas estão usando mais do que apenas suas costas para se sustentarem. Elas estão espalhando seus corpos, seu peso é distribuído de forma diferente, diferentes músculos são solicitados. (Spier, 2011:147)"129

Em uma conversa ${ }^{130}$ entre William Forsythe e Nikolaus Hirsch sobre aspectos do projeto, são feitas as seguintes considerações:

Hirsch: No Bockenheimer Depot, nós colaboramos com algo que oscila ou transita entre determinação e indeterminação. Eu ainda não sei como descrever o nosso papel: será que nós projetamos o espaço, num sentido literal de predeterminação ou designação?

Forsythe: Ele está pronto? Ainda não. Isto é algo como um “proto projeto". A primeira decisão diz respeito ao chão. De certa forma, as pessoas deveriam voltar para o chão. É por isso que o espaço é muito orientado para o solo. (Revista ballet$\operatorname{tanz}, 2004: 20$ e 21, tradução nossa). ${ }^{131}$

O espaço do Bockenheimer Depot, neste projeto, sugere uma aproximação do chão, o que coincide com uma orientação bastante explorada também pela dança, já que o solo é a primeira superfície de contato e o plano que está em negociação direta com o corpo do dançarino em suas evoluções espaciais. Aproximar o corpo do chão é reorganizar equilíbrios e toda a estrutura muscular e óssea em busca de novos modos de se movimentar. A força da gravidade passa a agir diretamente sobre estruturas já conhecidas provocando a descoberta de novas relações e modos de interagir com o meio.

As sugestões espaciais apresentadas por Hirsch e Forsythe são orientadas pelo surgimento de posições, relações e movimentos inesperados e não pela determinação de

\footnotetext{
${ }^{129}$ Texto original: "People are using more than just their backbones to support themselves. They are spreading their bodies out, their weight is differently distributed, different muscles are required." (Spier, 2011:147)

${ }^{130}$ Conversa publicada na revista ballet-tanz, das Jahrbuch/ Bill's universe 2003/2004. "Planning the Unpredictable William talks to architect Nikolas Hirsch about the temporarity of body, space and dance."

${ }^{131}$ Texto original: "Hirsch: In the Bockenheimer Depot, we collaborated on something that oscillates or shifts between determination and indetermination. I am still not quite sure how to describe our role: Did we design the space, in a literal sense of predetermining or designating? Forsythe: Is it design? Not yet. It is something like protodesign. The first decision concerned the floor. In a way, people should get back to the floor. That's why the space is very floor-oriented. (Revista ballet-tanz, 2004: 20 e 21)."
} 
ocupações e comportamentos espaciais específicos.

A solicitação do corpo a partir de estímulos que fogem dos padrões já conhecidos provoca alterações de rota que conduzem o movimento para lugares desconhecidos. A desorientação e a construção instantânea de novos eixos orientadores desmontam estruturas fixas e possibilitam rearticulações físicas.

$\mathrm{O}$ arquiteto Nikolaus Hirsch comenta a relação entre aquilo que é proposto e as situações inesperadas que surgem quando as pessoas passam a interagir com os elementos e estímulos sugeridos:

É interessante como elementos modulares são transformados em camas, cobertores, travesseiros, de modo quase imprevisível. O que, na verdade, é algo que me interessa muito: como que algo que foi planejado é capaz de desaparecer como forma. Uma oscilação entre algo planejado e algo que se desenvolve. Algo aparentemente contraditório: Planejar o imprevisível. (HIRSCH, 2004: 24, tradução nossa $)^{132}$

Esse espaço que provoca novas percepções e experiências do corpo no espaço toca em questões fundamentais que tratam da desmontagem de sistemas e mecanismos já conhecidos.

Explorar temporalidades e possibilidades espaciais coincide com a produção de novas lógicas e abordagens na observação e experiência de fenômenos, implica provocar sustos aos sentidos para que novas formações e percepções se instalem:

\begin{abstract}
Assim que o momento requer que nos abandonemos para receber essa "luminosidade" capaz nos cegar e de nos fazer cair do cavalo. Logo haverá o tempo de revelar os vazios e de pensar com clareza. Mas, para começar, precisamos de revelação, precisamos que um golpe contra o chão nos corte a respiração por um tempo, e pelo menos no momento desta apneia, deixarmo-nos levar pelo desejo e capricho da intuição. "( CONDE-SALAZAR, Jaime em LEPECKI, 2006: 11, tradução nossa) $)^{133}$
\end{abstract}

As posições acostumadas do corpo desviam de suas zonas confortáveis, do já conhecido e dos apoios cotidianos. Um pensamento coreográfico é produzido nessa zona de desvios, desequilíbrios e negociações com estímulos ambientais. Esse pensamento negocia com regras institucionais, com padrões de comportamento e favorece novas experiências de tempo e

${ }^{132}$ Texto original: "It is interesting how modular elements are reconfigured into beds, blankets, pillows, in an almost unpredictable way. Which, in fact, is something that interests me a lot: how something that we planned is able to disappear as a design. An oscillation between something planned and something that evolves. Something seemingly contradictory: Planning the unpredictable." (Revista tanz-ballet, 2004: 24)

${ }^{133}$ Texto original: "Lo que el momento requiere es que nos abandonemos para recebir ese fogonazo capaz de cegarnos y hacernos caer de caballo. Luego ya habrá tiempo de ir rellenando vacíos y de pensar con claridad. Pero para comenzar, necesitamos uns revelación, necesitamos que el golpe contra el suelo nos corte la respiración durante un ratito, y, al menos en ese momento de apnea, dejarnos llevar por el deseo, el capricho y la intuición.” (Jaime Conde-Salazar no livro Agotar la Danza, Lepecki, 2006: 11) 
espaço.

Esse projeto, em parceria com um arquiteto, confirma mais uma vez o interesse de Forsythe por incursões e articulações que incluem corpo e percepção em um processo dinâmico no qual é possível mudar tudo de lugar.

A noção de arquitetura, ainda que esteja amparada em uma sobreposição de aspectos físicos, objetivos, subjetivos, visíveis e invisíveis, oferece ferramentas objetivas que auxiliam na investigação de particularidades do espaço. As contribuições de princípios arquitetônicos aparecem no entrelaçamento de referencias em uma trama que evidencia propriedades e qualidades nos intervalos entre a matéria e as condições ambientais. São massas, pesos, volumes, formas, esquemas geométricos, curvas, passagens, estruturas e formações que avançam sobre o corpo e sobre os sentidos.

No conceito de coreografia de William Forsythe a observação de linhas, espirais, posições, planos e torções são algumas das orientações para o movimento. Essa noção desenha o corpo no espaço e o espaço no corpo. Com isso, é possível afirmar que em suas pesquisas Forsythe investiga também fundamentos que se cruzam na definição de arquitetura.

A autora Juliet Rufford (2015) fala sobre a noção de arquitetura sob uma perspectiva ampla e associada a essa construção de relações.

\begin{abstract}
Arquitetura envolve uma ampla gama de considerações que vai da poética e planejamento, simbolismo e estrutura à legislação de saúde, segurança e logística de uso. Trata-se da "configuração" inteligente de espaço a partir do nível macro do desenho urbano e arquitetura paisagística ao nível micro do detalhe e construção de projetos de móveis. Arquitetura, finalmente, diz respeito à escultura do espaço e a organização dos ambientes em que vivemos e agimos - e que agem sobre nós através do uso de luz, materiais, tecnologia, textura e som. (RUFFORD, 2015:12, tradução nossa) ${ }^{134}$
\end{abstract}

E é neste ponto de análise que Spier (2011) destaca a coincidência de afinidades e pontos de contato entre o conceito de coreografia experimentado por Forsythe e a noção de arquitetura. "Isso ajuda, portanto, a explicar afinidades "arquitetônicas" com o seu trabalho, sua definição de coreografia poderia ser também uma definição de arquitetura. (Spier, 2011:139)" "135

\footnotetext{
${ }^{134}$ Texto original: "Architecture involves a large range of considerations, from poetics and planning, symbolism and structure, to heath and safety legislation and logistics of use. It is about the thoughtful design of space from the macro-level of urban design and landscape architecture to the micro-level of construction detailing and furniture design. Architecture, finally, is about the sculpting of space and the organization of the environments in which we live and act - and which act upon us - through the use of light, materials, technology, texture and sound." (Rufford, 2015:12)

${ }^{135}$ Texto original: "It also helps to explain architect's affinity for his work, for his definition of choreography could as well be a definition of architecture". (Spier, 2011:139)
} 
Ainda sobre as afinidades entre observações do corpo em interações espaciais que tomam como referencial aspectos e indicações da arquitetura, vale à pena mencionar o interesse de Rudolf Laban por estruturas espaciais e o início de sua carreira como arquiteto. Laban, que inicia sua carreira estudando arquitetura, logo investigará as possibilidades arquitetônicas do movimento e do corpo. Essa possibilidade de observação das dinâmicas corporais sob o ponto de vista de recursos e métodos de investigação do espaço utilizados pela arquitetura permite um olhar sobre o corpo sob uma perspectiva que contempla a análise de planos, volumes, linhas, superfícies e interações. O corpo é analisado e estudado como estrutura e matéria suscetível às variações do meio. Se o olhar do arquiteto procura e negocia com ângulos, passagens e a disposição de acessos e áreas que criarão relações e possibilidades de deslocamento, o diálogo da arquitetura com estudos e procedimentos práticos que investigam dinâmicas entre corpo e espaço intensificará as possibilidades de diálogo do corpo com o entorno e vice-versa.

Essas questões que surgem nas investigações e práticas de Forsythe discorrem sobre uma das questões centrais da produção de arte nos séculos XX e XXI, a superação do aparecimento da obra como elemento individual e imune às interferências do ambiente. $\mathrm{O}$ que vemos em Forsythe é o desejo de produzir espaços plurais que são gerados em processos de ambientação que lançam linhas e traços para além dos contornos do corpo e produzem experiências e problemáticas presentes no eventos artísticos contemporâneos. Sobre a criação desses espaços plurais a autora Juliet Rufford (2015) faz as seguintes considerações:

\begin{abstract}
Um projeto de teatro que criou os tipos de espaços informais que promovem a hospitalidade e a inclusão social ao mesmo tempo em que se recusam a vender fantasias sociais da casa ou a repetição automatizada de um espaço sequencial definido, que são heranças burguesas, desafia o modelo de capitalismo da moradia privada e molda um espaço de convívio, no sentido de um lugar compartilhado - um lugar que ligaria o teatro com outras casas (por exemplo, cafés, casas públicas) destinadas à sociabilidade e ao diálogo. (Rufford, 2015: 67, tradução nossa) ${ }^{136}$
\end{abstract}

O projeto de ocupação do Bockenheimer Depot propõe novas articulações espaciais e promove movimentos de interação que aproximam pessoas. O espaço é aberto a uma ocupação pública.

O corpo experimenta novas condições ao mesmo tempo em que promove o surgimento

\footnotetext{
136 Texto original: "A theater project that created the sorts of informal spaces that foster hospitality and social inclusivity while refusing to peddle social fantasies of the home or to repeat unthinkingly the contained, sequential space that are bourgeois inheritance could challange capitalism's model of the private dwelling and model a more convivial, shared sense of place - one that would link the theatre with certain other houses (e.g. coffeehouses, public houses) intended for sociality and debate." (Rufford, 2015: 67)
} 
de arranjos dinâmicos que ativam o ambiente instalativo projetado por Forsythe. E é neste ponto que Forsythe oferece ao público a possibilidade de experimentar princípios que fundamentam o seu trabalho, do mesmo modo em que coloca em questão a utilização de espaços públicos e privados. De acordo com Spier, neste projeto Forsythe "confrontou o público com suas ideias sobre o pensamento coreográfico e explicitou uma crítica sobre a privatização de espaços públicos. (SPIER, 2011:146)”

\section{Lugares públicos}

No texto a seguir abordarei aspectos que se referem a duas propostas de Forsythe que acontecem em lugares públicos e que desafiam não só padrões institucionais, como também formas e modelos de organização que operam em vias públicas nos quais instruções e ordens tendem a orientar os sentidos.

Nestes projetos ou propostas públicas o corpo que se movimenta é aquele que geralmente encontramos em definições como passante e transeunte, por exemplo. Corpos que cruzam as cidades, que visitam museus, bienais e que esperam o próximo trem. São esses os corpos e as suas potencialidades coreográficas em diferentes situações que despertam a curiosidade de Forsythe em suas propostas que cruzam os limites da instituição e se afirmam em passagens públicas. Diferentes dinâmicas incentivam relações nas quais objetos, coisas e instruções compõem uma multiplicidade de ambientes, de pensamentos que acontecem na desordem e na reestruturação de vínculos já conhecidos e mantidos por diretrizes ou ordens que regulam os lugares públicos.

Sob essa perspectiva de produção e investigação artística, diferentes experimentos desafiarão a arte a uma multiplicidade de relações e questionamentos que acontecerão no corpo, no espaço, nas telas e em intervenções públicas e institucionais que convocarão o público e as instituições aos mais diversos diálogos sobre a arte como fenômeno social e provocador do sujeito.

O autor André Lepecki contribui com importantes considerações sobre arte e política. No texto "Coreopolítica e coreopolícia", Lepecki faz uma análise ampla e precisa de relações e dinâmicas que se estabelecem em contextos públicos a partir de apontamentos sobre política e polícia. Para tratar da diferença entre os conceitos, o autor escolhe a noção de "dissenso", do filósofo francês Jacques Rancière. $\mathrm{O}$ dissenso, que entrelaça arte à política, atua na produção de rupturas de hábitos e comportamentos. E é sob esse ponto de vista que ele fundamentará 
seu argumento de que a estreita relação entre arte e política, principalmente na arte contemporânea, pode ser constatada na produção de rupturas com hábitos e padrões de conduta. Essa dimensão política que se embaralha com a arte estaria presente em intervenções que modificam o modo de ver e se relacionar com o mundo.

Enquanto a dimensão política age na rearticulação de ordens, a polícia atua na determinação e tem como função fazer cumprir a lei. Lepecki pontua, valendo-se de colocações de Jacques Rancière, as diferenças entre as noções de política e polícia e inaugura dois termos que tratam de possibilidades de arranjos ou estruturas que definem ou reformulam ordens: a coreopolítica e a coreopolícia.

$\mathrm{Na}$ evidência do corpo, em suas capacidades e potências, os termos acima se relacionam com os modos como os sentidos são produzidos ou perturbados. A coreopolítica estaria vincula ao dissenso, a produção de movimentos que geram novas relações do corpo com o chão, com o entorno, e a coreopolícia atuaria na manutenção de fluxos e circulações que definem os espaços urbanos de acordo com funções e determinações da cidade. Lepecki explica:

O fim do coreopoliciamento é o de desmobilizar ação política por via da implementação de certo movimento que, ao mover-se, cega e, consensualmente, é incapaz de mobilizar discórdia; um movimento incapaz de romper com a reprodução de uma circulação imposta (e retificada como natural à imagem própria da cidade como espaço para o espetáculo permanente do movimento supostamente livre). (LEPECKI, 2012:54)

O trabalho City of Abstracts, no qual uma câmera ao vivo captura a imagem de pedestres em diferentes locais da cidade e um programa de computador deforma e modula as imagens desses corpos, acontece em lugares públicos em diferentes cidades e países desde o ano 2000 . 


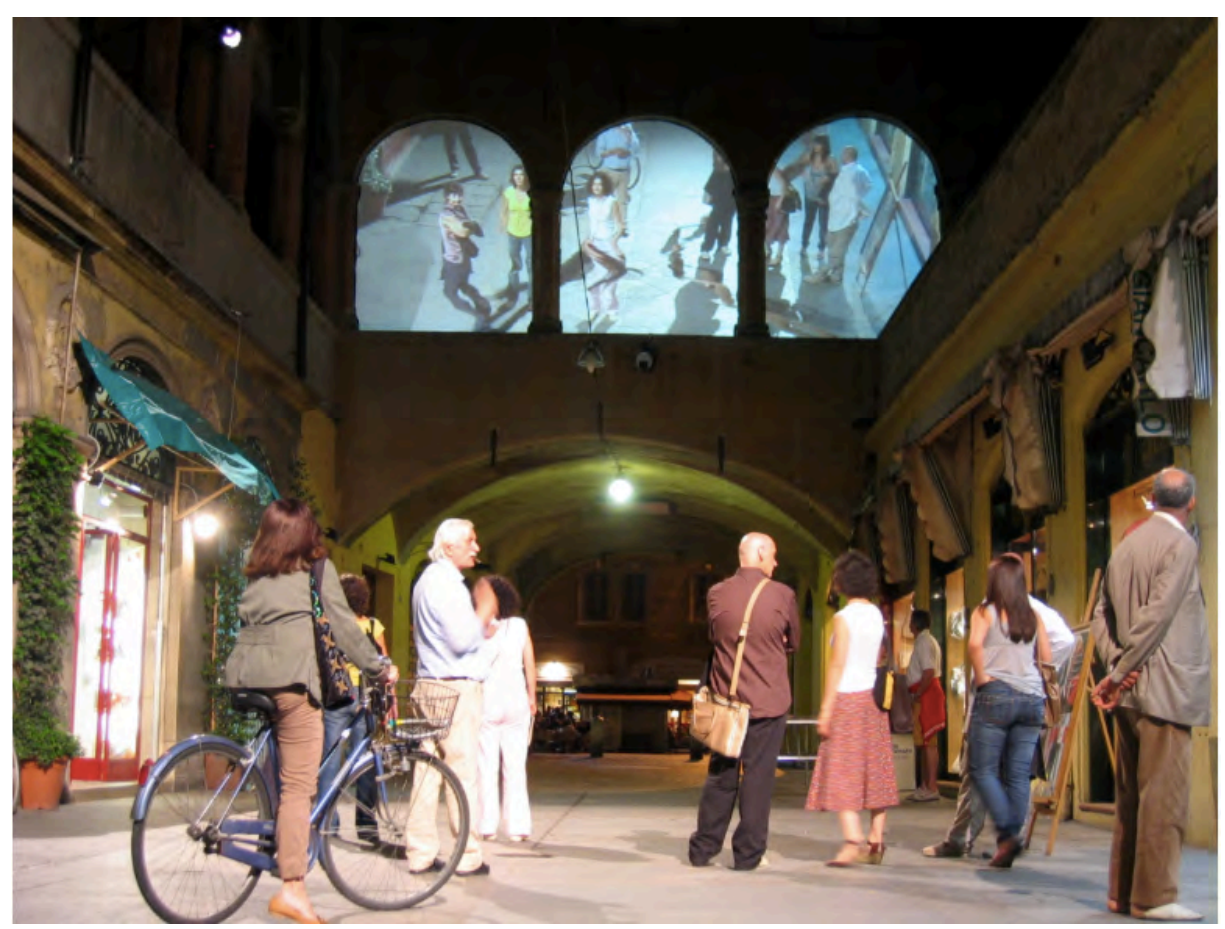

City of Abstracts

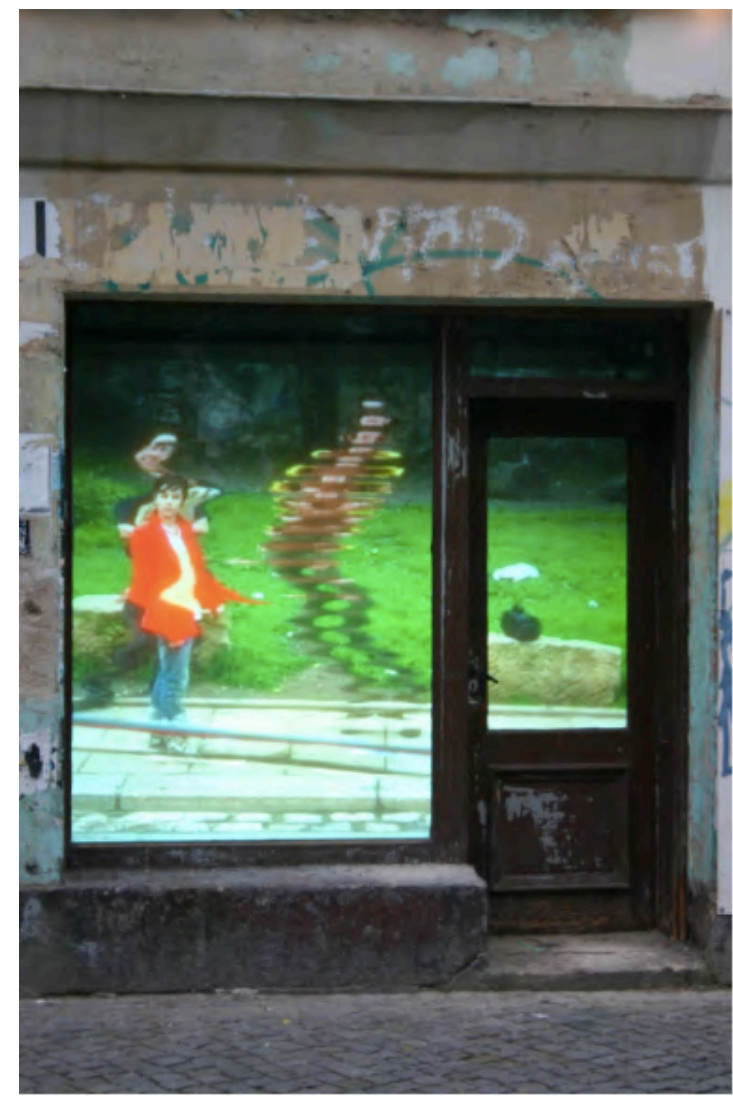

City of Abstracts 
William Forsythe, em conversa com Gerald Siegmund ${ }^{137}$ sobre projetos como "City of Abstracts", fala sobre o seu interesse pela intervenção em espaços públicos. Forsythe aponta para o fato de estar mais preocupado com o espaço e com o seu desdobramento do que com a sua forma ${ }^{138}$. Esta afirmação dá ênfase as suas considerações sobre as inúmeras modulações possíveis entre corpo e espaço em diferentes situações.

No que diz respeito ao lugar teatral, Forsythe fala sobre as restrições observadas nas disposições espaciais que definem a posição e o ponto de vista do espectador. Ele diz ainda que "O espaço dá o tempo. A distância da plateia até o palco determina a recepção. Eu acho que há uma série de afetos humanos que surgem automaticamente, dependendo da proximidade com a figura humana ou com a figuração" ${ }^{139}$ (Forsythe em Siegmund, 2001:73). Forsythe critica ainda o condicionamento da percepção no âmbito dos grande teatros, lugar onde uma certa história do teatro atua de forma incisiva interferindo nas expectativas, no olhar e nas disposições do espaço.

Desde o trabalho Artifact (1984) que suas investigações se pautam em desdobramentos espaciais que testam os limites da instituição teatral e de seus aspectos históricos. "Em princípio, este é o projeto com o qual estou preocupado desde "Artifact", mas nem toda dança necessita de um espaço de teatro a fim de criar um projeto próprio. E vice-versa, nem todos os diálogos sobre dança pública precisam de um teatro." (Forsythe em Siegmund, 2001:73) ${ }^{140}$ Ao longo de sua trajetória Forsythe descola a dança da ideia de um lugar ou situação específicos. A dança aparecerá vinculada ao seu interesse em construir relações espaciais que independem de regras e disposições impostas por sistemas e delimitações institucionais.

Forsythe, questionado sobre a produção de coreógrafos contemporâneos que optam por abordar a questão da representação na dança dentro do próprio contexto institucional, onde existem expectativas em relação ao modo como os trabalhos serão criados e apresentados ao público, fala que é preciso se testar repetidas vezes os limites do sistema "teatro". E nesse ponto sinaliza que mais importante do que romper com os limites impostos é negociar com essas limitações.

\footnotetext{
${ }^{137}$ Texto "Coreographic Thinking" ( Gerald Siegmund in conversation with William Forsythe) - revista Ballet Tanz, 2001.

${ }^{138}$ Texto original: "I am basicaly more pre-occupied with space and the folding of the space than I am with form." (Forsythe em Siegmund, 2001:73)

139 "The space gives you timing. The distance the audience has to the stage determines the reception. I think there are a number of human affects that automatically arise depending on proximity to the human figure or figuration". (Forsythe em Siegmund, 2001:73)

${ }^{140}$ Texto original: "In principle, this is the project with which I am preoccupied with since "Artifact", but not all dancing needs theatrical space in order to create a project of its own. And vice versa not all discourses in public dancing need theater". (William Forsythe em entrevista a Gerald Siegmung, 2001:73)
} 
A questão é, no entanto, se como artista você está disposto a abandonar ou a negociar com os limites dos projetos do século XVIII (...). Essa negociação dos limites é o ponto interessante. Já que de algum modo ainda somos um pouco reféns do sistema da época do Iluminismo. (FORSYTHE, entrevista SIEGMUND, 2001: 73 , tradução nossa) $)^{141}$

E é na negociação com padrões e limitações que Forsythe se lança a um projeto de democratização da dança que se realiza, principalmente, em corpos amadores nas mais diversas situações. Pode-se dizer que a dança vai para as ruas, museus, bienais e acontece sob condições que não são determinadas por definições espaciais já conhecidas, como aquelas previstas pelos teatros, por exemplo.

É exatamente por isso que eu fiz algo como o "Bouncy Castle" ou "City of Abstracts", junto com Dana Caspersen, porque eu sinto que um projeto democrático em dança seja talvez quase impossível de se realizar dentro de um teatro. Parece que só "solicitando" amadores você pode chegar a uma forma verdadeiramente democrática de organização em dança. Enquanto se estiver em um ritual anunciado do início de uma performance e as pessoas tiverem que estar em um determinado lugar em um certa hora, isso não será possível. (FORSYTHE, entrevista a SIEGMUND, 2001:73, tradução nossa) ${ }^{142}$

Forsythe descreve o trabalho "City Of Abstracts" no qual algumas pessoas estão sentadas em uma parada de trem ${ }^{143}$ quando de repente percebem que suas imagens estão sendo projetadas em uma parede do outro lado da rua. A surpresa é seguida por tímidas tentativas de interação com a projeção ao vivo de vídeo. Forsythe comenta ainda que:

Eles aos poucos reconhecem o que está acontecendo e participam balançando suas sacolas de compras ou abrindo e fechando seus guarda-chuvas. $\mathrm{O}$ interessante é que as pessoas que estavam do outro lado da rua não entendiam por que essas pessoas todas estavam se comportando daquela maneira. (FORSYTHE em entrevista a SIEGMUND, 2001:74, tradução nossa) ${ }^{144}$

\footnotetext{
${ }^{141}$ Texto original: "The question is, however, whether as an artist you are willing to abandon or to negotiate the boundaries of the projects of the 18th century (...). This negotiation of the limits is the interesting point. In a way we are still held a bit hostage by the system of the Age of Enlightenment." (William Forsythe em entrevista a Gerald Siegmung, 2001:73)

${ }^{142}$ Texto original: "That's precisely why I did something like "Bouncy Castle" together with Dana Caspersen or "City Of Abstracts" because I feel the Project of the democratic dance is perhaps almost impossible to achieve within a theatre. It seems that only by ambushing amateurs can you arrive at the truly democratic way of organising dance. As long as they are in a ritual announcement of the performance beginning and people having to be at a certain place at a certain time, this will not be possible. (William Forsythe em entrevista a Gerald Siegmung, 2001: 73)

${ }^{143}$ Ou paradas de trem, no caso da versão aqui mencionada do trabalho City Of Abstracs, que aconteceu em Frankfurt.

${ }^{144}$ Texto original: "They slowly realised what was going on and joined in by swinging their shopping bags or opening and folding their umbrellas. What was interesting was that people standing on the other side of the Road did not understand why those people were all behaving that way." (William Forsythe em entrevista a Gerald Siegmung, 2001: 74, tradução nossa.)
} 
Em uma análise possível deste trabalho, é possível observar a dança desvinculada de regras, padrões temporais, estruturas e suportes já conhecidos. Muito embora fique evidente na produção de Forsythe seu interesse pelo movimento constante em mudar as coisas de lugar sem a intenção de encontrar um lugar de repouso ou um ângulo fixo de observação dos eventos. Se hoje ele observa os fenômenos sob o ponto de vista da dança, amanhã ele observará sob o ponto de vista da arquitetura, da coreografia, da física, da matemática e assim por diante sem procurar paradeiros seguros e estáveis.

$\mathrm{O}$ interessante nessa proposta é o desvinculamento da dança dos aparatos e normas institucionais. O que era dança ou balé sob uma perspectiva determinada e previsível surge agora na parada de ônibus, na parede precária, no prédio abandonado, na fachada de alguma casa antiga e em vestígios de demolição. Os corpos se imprimem na cidade. Novas instruções geram dissensos, movimentos que alteram os fluxo cotidianos.

No trabalho Instruction, de 2003, apresentado em Paris, quinze instruções coreográficas foram distribuídas pela cidade. Steven Spier (2014) comenta que essas instruções foram impressas em Braille - o que confere à noção de coreografia uma perspectiva física e não apenas visual $^{145}$ - e distribuídas em espaços públicos, escolas e bibliotecas. De acordo com Spier, algumas instruções foram divulgadas em placares, na internet, nas rádios e em revistas. Essas instruções, que sugerem a execução de uma sequências de movimentos, convidavam os passantes a uma experiência coreográfica que poderia ser ignorada ou acontecer na rua, ali onde eles liam as indicações, ou mesmo em casa.

\footnotetext{
${ }^{145}$ Fala de Steven Spier na palestra disponível: https://www.youtube.com/watch?v=NI8hRRTTHag. Acesso em agosto de 2015.
} 


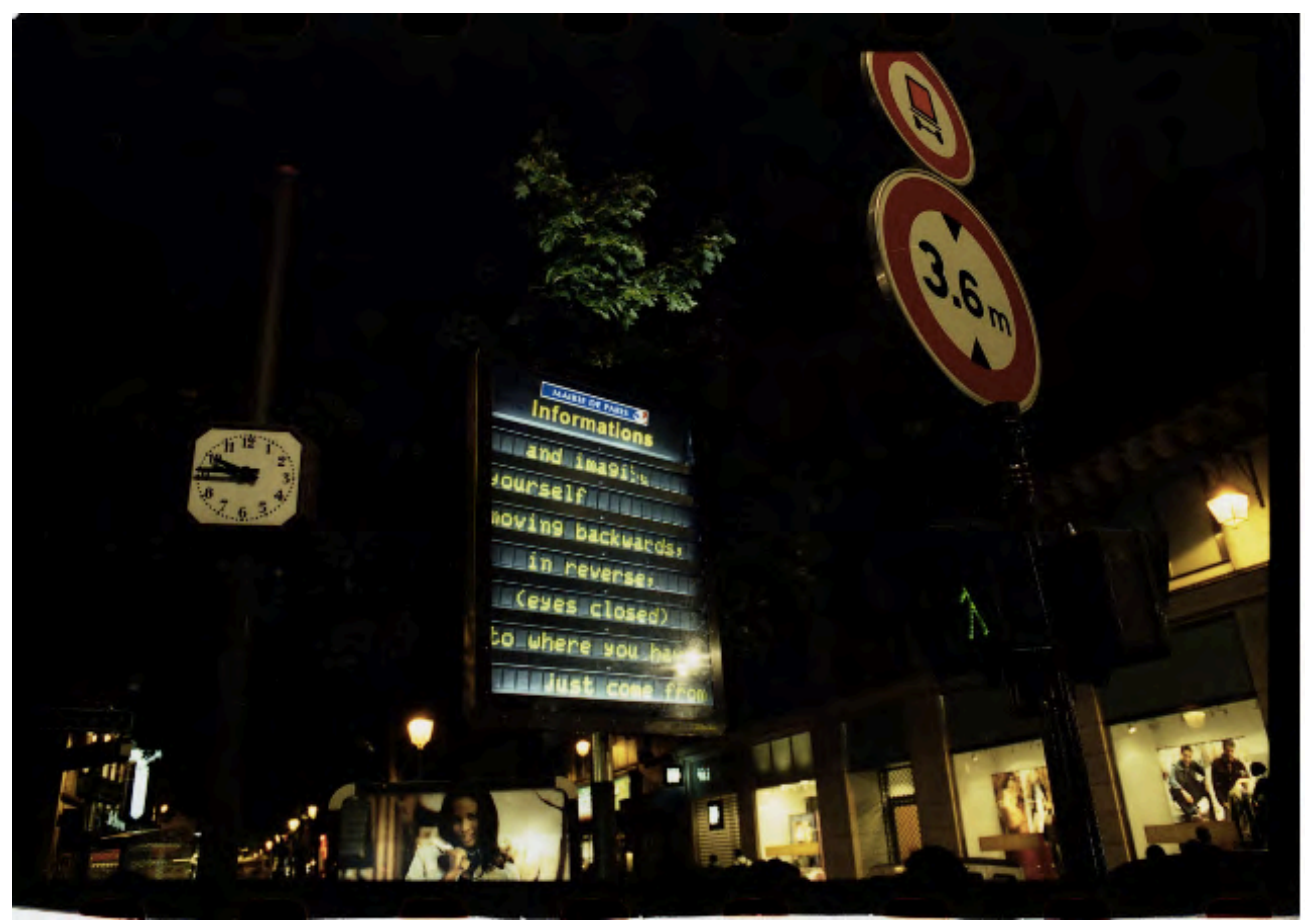

Instruction

Abaixo o texto de uma das instruções oferecidas em uma das versões do trabalho:

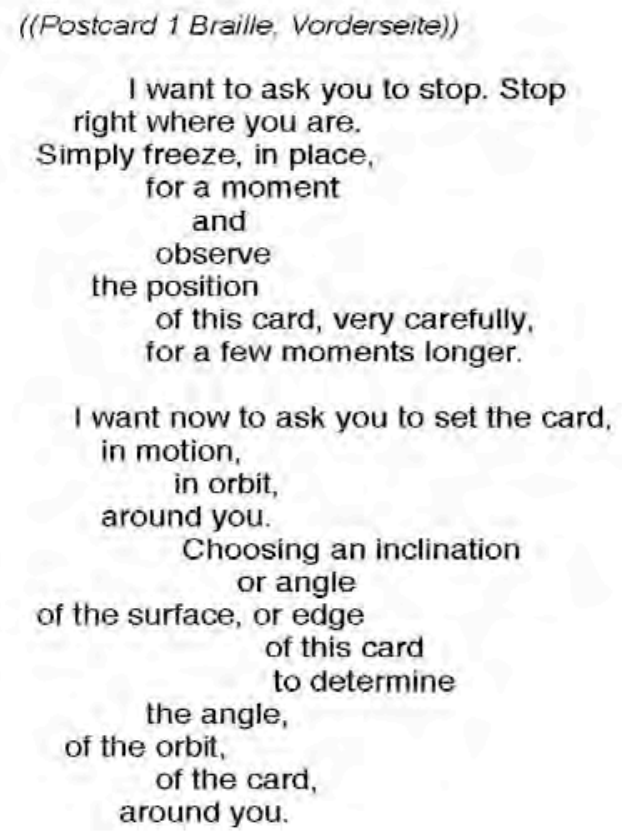

A interação do corpo com o cartão sugerida pelas instruções solicitam inicialmente uma parada e em seguida a observação de ângulos e relações possíveis com o material ou com essa superfície. O pensamento coreográfico aqui é uma negociação entre a visualização da movimentação descrita por Forsythe com a sua execução concreta no espaço. Há uma sobreposição de espaços mentais e abstratos com experiências corporais físicas. A orientação 
visual é aqui transformada em passeios por linhas imaginárias e desenhos espaciais experimentados pelo corpo.

O que chama a atenção é a possibilidade de abordar a dança sob novas condições e a partir de relações mais livres e fluídas entre corpo e espaço. Observar a dança sob o ponto de vista das dinâmicas sugeridas acima é mexer nos mecanismos que fixam o olhar para um ponto determinado e definido, é encontrar novas fórmulas ou acessos para um evento que se fundamenta na construção de relações, desenhos, rotações e linhas.

A atuação de Forsythe demonstra um percurso investigativo no qual espaço e tempo se manifestam no trânsito entre instituições e passagens públicas.

Pode-se dizer até mesmo que o balé reaparece nesses trabalhos como paisagem de fundo, como desenho que se inscreve em novas geometrias e em terrenos irregulares, o balé desaparece e não importa o nome ou a categoria a que esses experimentos e propostas podem pertencer. O mais interessante e importante é a observação de estruturas espaciais, temporais e torções que aparecem no corpo do dançarino, em seus primeiros trabalhos, e que se manifestam agora também em passagens públicas e em corpos amadores. $\mathrm{O}$ foco de atenção percorre novos e inusitados caminhos, o espectador passa a fazer parte de uma espacialidade que solicita sua presença física em situações nas quais seu corpo e sua percepção experimentam novas variações e intensidades.

Se no projeto do Bockenheimer Depot, Forsythe experimenta situações e encontros que simulam, de algum modo, o que acontece em lugares públicos, como parques, praças etc., nos trabalhos City of Abstracts e Instructions o coreógrafo interpela as pessoas nas ruas, em seus trajetos cotidianos. O susto é aqui mais evidente e acontece no trânsito. Não há a necessidade de se dirigir para um lugar específico, o trabalho vai ao encontro e interpela os corpos que atravessam e transitam pela cidade.

Esses trabalhos evidenciam descolamentos em relação aos vínculos institucionais e motivam diálogos sobre a função e a prática da arte em ambientes públicos e privados.

A coreografia ou o pensamento coreográfico proposto por Forsythe coincide com a noção de dissenso quando provoca paradas, mudanças de direção e desvios de passagens repetitivas e já automatizadas pelo corpo e pelos sentidos.

\section{Sobre a instituição}

É importante pontuar aqui que os limites institucionais se manifestam, na maioria da 
vezes, em expectativas e exigências que condicionam o acontecimento artístico a contextos temporais e físicos nos quais os papéis e as funções são previamente definidas. Lá está a obra e lá está o público com data e hora marcada. E lá estão também os dançarinos se apresentando a uma plateia. Uma mudança radical dessas normas pode comprometer a viabilidade do trabalho. E é assim que as instituições pontuam seus campos possíveis de ação. Negociações são possíveis, aberturas e mudanças também, porém uma mudança radical de perspectiva só é possível quando esta é assumida e assimilada pela própria instituição. No contexto das artes visuais, se comparado ao das artes cênicas, as negociações entre formatos instituídos e processos que ampliam as relações e leituras das experiências artísticas aparecem com mais evidência quando museus e centros de arte apresentam trabalhos que ora se apresentam como objetos, ora como propostas de interação e ora como acontecimentos efêmeros que só poderão ser acessados posteriormente a partir de registros em vídeos ou fotos. Essa incorporação de diferentes práticas, linguagens e ações somadas à atuação das atividades educativas e às propostas curatoriais que muitas vezes desestabilizam os meios conhecidos de acesso aos trabalhos de arte, evidenciam importantes reorganizações que acontecem no âmbito institucional. Muito embora seja importante frisar que existem ordens, sobretudo mercadológicas, que regulam toda a desordem que altera padrões e propõe novas relações com a produção de arte.

Os diálogos e negociações com a instituição apontados por William Forsythe podem ser observados a partir das problemáticas presentes nas reflexões e episódios propostos por Luís Camillo Osório em diferentes momentos e situações dos trabalhos de Hélio Oiticica em contextos institucionais.

\section{Subjetividades ambulantes}

No que diz respeitos às lógicas institucionais, menciono o artigo "A política das artes e/ou a apropriação institucional: a partir de alguns casos com os Parangolés de Hélio Oiticica”, de 2004, do crítico e curador Luís Camillo Osório. Neste texto Osório discute aspectos dos dispositivos institucionais e das práticas expositivas a partir de dois episódios com os Parangolés, de Hélio Oiticica. Uma mesma obra e a sua relação com a instituição em diferentes momentos pontua as diferenças conceituais e estruturais que regulam e delimitam como e onde o fenômeno da arte pode acontecer.

O primeiro episódio descrito por Osório (2004) aconteceu em 1965, quando Oiticica, 
sambistas e instrumentistas da Mangueira chegaram ao vão do Museu de Arte Moderna do Rio de Janeiro "em grande procissão festiva"146 vestindo os Parangolés e foram logo barrados na entrada do museu. O evento, que era em si a própria obra de Oiticica, esbarrou em limitações institucionais, assim comentadas por Osório: "tratando-se de um museu de arte ainda marcado pelas premissas das belas-artes que dividia e classificava os meios expressivos e os modos de ser e experienciar cada gênero artístico, aquele não era um espaço do samba, de sambistas, de músicos e, por que não dizê-lo, de favelados." Sendo o museu um lugar de restrições, o evento acabou acontecendo nos jardim e também no vão do museu.

Os trabalhos experimentais só ganham espaço nos museus quando seus processos se transformam em formas possíveis e aceitáveis por novas regras institucionais, o que acontece, principalmente, a partir do final dos anos 1960. Osório comenta:

(...) os museus passaram paulatinamente a incorporar os processos experimentais entre as obras colecionáveis e exibíveis, redefinindo e flexibilizando o estatuto do que seria obra, inscrevendo em sua rotina - curatorial, educativa, museográfica, arquitetônica - elementos intrínsecos da crítica institucional. Destacaria então que a partir do final dos anos 1960 começa a mudar o estatuto do que seja obra de arte, as formas expositivas, a estrutura institucional (o museu, as escolas de belas-artes, as galerias, as bienais). Neste campo ampliado, a prática curatorial nasce incorporando dinâmicas ao mesmo tempo críticas e espetaculares, obrigando-nos a rever o que podemos esperar da arte em um mundo aparentemente sem alternativas extrainstitucionais. (OSÓRIO, 2004:26)

O segundo episódio aconteceu em 2002, no mesmo museu, porém agora na ocasião da exposição "Hélio Oiticica: obra e estratégia", mostra que deu destaque aos trabalhos experimentais de Hélio Oiticica e a qual disponibilizou Parangolés para quem os quisesse vestir. Osório discorre sobre o ocorrido com o artista pernambucano Lourival Cuquinha, que vestiu um dos Parangolés e permaneceu com ele durante a festa de abertura que aconteceu do lado de fora do museu. Osório comenta a dificuldade que Cuquinha encontrou para devolver o trabalho:

\footnotetext{
Quando quis devolvê-lo o museu já estava fechado e não o deixaram mais entrar. Conclusão: seu casaco ficou dentro do MAM e o parangolé ficou com o artista indo com ele para a Lapa, área boêmia do Rio e depois para casa. Na manhã seguinte, toca o telefone de sua casa e é deixada a seguinte mensagem por uma funcionária do museu: ou devolve até o meio-dia ou a polícia será mobilizada. (OSÓRIO, 2004:27)
}

Aconteceu que o mesmo trabalho que teve sua entrada barrada na porta do museu é agora objeto de desejo, com valores agregados e submetido às ordens impostas pela

\footnotetext{
${ }^{146}$ Artigo de Luís Camillo Osório. ArteFilosofia Ouro Preto n.17, dezembro de 2014. Disponível no link: http://www.raf.ufop.br/pdf/artefilosofia_17/25_31LuisCamillo.pdf. Acesso em outubro de 2014.
} 
instituição. Osório dá continuidade ao artigo pontuando aspectos e problemáticas políticas que se impõem no contexto mencionado acima.

As relações entre arte e instituição coincidem com situações de conflitos, negociações, aberturas e limitações que colocam em jogo a própria prática da arte. E é neste contexto que a propostas experimentais desempenham um papel fundamental na rearticulação de discursos e na dissolução de restrições normativas. Osório comenta:

\begin{abstract}
As normas sempre existiram e existirão, cabe à arte - aos artistas e curadores negociar com elas e deslocar seu poder de determinação sobre as possibilidades artísticas. Dadas as restrições, o que se pretende é perceber o modo como elas se transformam a partir dos conflitos instaurados por práticas experimentais, abrindo horizontes criativos e estratégias poéticas até então inimagináveis. (OSÓRIO, 2004:27)
\end{abstract}

Os espaços das galerias e dos museus, por exemplo, são questionados em suas funções quando novas lógicas e perspectivas espaciais e conceituais são criadas.

As transformações e as aberturas para novas possibilidades institucionais e artísticas dizem respeito, de acordo com Osório, à dimensão política da arte. E é neste contexto e nesta tensão entre arte e instituição que acontecem transformações que alargam conceitos e alteram os mecanismos de produção de sentidos. Seja dentro da instituição, testando e provocando os seus limites, ou fora dela, afirmando que as ações artísticas não estão vinculadas às normas institucionais, o que importa são as dinâmicas que questionam os pontos de vista estáveis e fixos que conduzem a percepção para lugares já conhecidos. Osório alerta:

\footnotetext{
A possibilidade de engajamento combativo no interior das instituições tem em vista resistir aos modelos instituídos, ou seja, ampliar e multiplicar o modo pelo qual a arte produz sentido. Neste processo, na tensão entre adequação e inadequação, a arte mantém-se experimental, resistindo às convenções e aos modos de perceber e falar fixados historicamente. (OSÓRIO, 2004:28)
}

Ao tecer considerações sobre os Parangolés, Osório trata da liberação e multiplicação de sentidos e relações através da obra, da proposição do artista, e com isso aponta uma questão fundamental que surge também nos trabalhos de William Forsythe no que diz respeito às fronteiras institucionais e à superação de limites entre artista e espectador e entre atividade e passividade.

Desloca-se o lugar do sentido que deixa de se concentrar na obra e passa a habitar o contato, indo da substância plástica para a relação estética - enquanto relação poético-criativa, na qual quem vê traduz o visível em ideias e movimentos. A dimensão participativa não deve ser instrumentalizada, é um convite a atualizar, em 
qualquer um, formas abertas de engajamento criativo com o sentido virtual, compreendendo-o como algo a ser produzido neste contato, nada passivo e harmônico, com múltiplos corpos e olhares. A participação implicada nestas obras, para além de uma forma específica de manuseio, diz respeito à multiplicação das formas de interação, das possibilidades constituintes de um devir-forma, devir-arte, devir-sujeito. (OSÓRIO, 2004:30)

A multiplicação de devires e sentidos surge nas produções contemporâneas a partir de mecanismos que questionam as formas e investigam as dinâmicas que mobilizam o evento artístico como procedimentos pautados na ação, no ato, naquilo que aciona o gesto. $\mathrm{O}$ agir, a construção de caminhos instáveis que contam com a presença e com as escolhas do artista ou do espectador provocam o surgimento da obra como processo, como lugar em construção e aberto aos mais variados estímulos. É possível dizer que esse lugar que surge sob as condições apontadas acima é o terreno performativo por onde circula grande parte dos trabalhos e das pesquisas de arte contemporânea. Uma virada performativa coincide com um giro que desloca o foco da forma para o impulso que aciona a ação. E é nesse momento que os gestos aparecem como memórias, fluxos e dinâmicas que são ativadas por um emaranhado complexo de forças no qual a arquitetura e os demais estímulos ambientais atuam provocando deslocamentos do corpo em diferentes sentidos e intensidades.

A abordagem performativa, pautada no ato, e a problematização da arte e da função e gesto do artista são geradores de confrontos que incentivam a observação da arte como campo de importantes transformações nas quais sujeito e espaço são instâncias instáveis que se constituem mutuamente em um processo contínuo de diferenciação ${ }^{147}$.

Neste processo é importante pontuar que as mudanças, mesmo que fundamentadas em experimentos e práticas de interação, correm o risco de cair em padronizações que passam a impor ordens e comportamentos repetitivos e deste modo cairiam novamente no consenso ou no senso comum. Osório reflete sobre a situação no contexto dos museus de arte:

Penso na multiplicação de formas de lidar com a arte, simétrica à multiplicação dos modos de ser da arte, sem reduzir tudo a uma espécie de imposição participativa no sentido da interação física ou mesmo tecnológica. Sigo acreditando que o museu deve equacionar linhas de fuga e linhas de composição diante das práticas cotidianas. Não podemos esquecer que temos visto ultimamente, junto à virada performativa, uma espetacularização dos museus, que por sua vez reduzem o espectador a mero consumidor de experiências fugazes. O tempo deste consumo é homogêneo ao ritmo acelerado do cotidiano, mobilizando sensações que não produzem um sensível heterogêneo àquele da vida cotidiana, antes confirmam seus parâmetros de afetação. É na possibilidade da inscrição de experiências não extensivas ao modo de ser de nosso aparato sensorial instituído, que me interesso pela incorporação da dinâmica performativa pelos museus. Acreditando nisso podemos ampliar os modos de ser do museu, tornando-o um lugar que misture jogo

\footnotetext{
${ }^{147}$ Conceito criado por Deleuze e intensamente explorado em seus textos.
} 
e resistência, experiência e experimentação com sentidos ainda não definidos. (OSÓRIO, 2004: 31)

\title{
Reinventar lugares
}

A experiências em arte tratam das formas de perceber, falar, desenhar, dança, pintar e compreender a realidade. Elas operam nesse registro virtual em que a linguagem e a subjetividade se reinventam na configuração de novas possibilidades de ser.

Se ruptura ou negociação com modelos e regras estruturantes, o que importa são os diálogos possíveis, os tremores que farão vibrar as forças que criam e desmontam sistemas.

William Forsythe atua entre contextos institucionais, regras e rupturas. Ele trabalha em instituições como o Balé de Paris e também em projetos que convocam a participação de corpos amadores. Ele experimentar novos passos, limites de regras e expectativas. Suas propostas são como ambientes ou lugares de ressonância nos quais diferentes corpos em diferentes situações podem experimentar movimentações e deslocamentos não previsíveis em suas atividades cotidianas e rotineiras.

Uma reflexão de William Forsythe que dá conta do assunto abordado nesta seção:

\begin{abstract}
Eu cheguei a pensar que fazer dança dentro de um teatro é muito conveniente, porque eles são muito bem organizados. O que poderia estar disponível ao ar livre é pensamento coreográfico. Eu estava tentando descobrir como eu poderia criar um ambiente coreográfico, o que, neste caso, significa ter a experiência de interagir com uma ideia que muda a maneira de pensar sobre a organização do seu corpo em movimento. (FORSYTHE em entrevista a SIEGMUND, 2001:74, tradução nossa) ${ }^{148}$
\end{abstract}

\footnotetext{
${ }^{148}$ Texto original: "I'd arrived at thinking that making dances inside a theatre is very convenient, because they are so well organised. What could be available outdoors is choreographic thinking. I was trying to figure out how I could create a choreographic environment, which in this case means having the experience of interacting with an Idea that changes the way you think about your body organizing moving. (Forsythe em entrevista a Siegmund, 2001:74)
} 


\title{
Formações
}

\author{
temporárias \\ Formações
}

Temporárias

\author{
Formações \\ temporárias
}

Formações

temporárias

Formações

Temporárias

Formações

temporárias 


\section{Advertências 1}

O termo formação pode ser ainda substituído por organização, arranjo ou composição. O mais importante é que tempo e duração não sejam ignorados.

O advérbio temporário é apresentado como condição que revela certa porosidade, transitoriedade e contornos sensíveis às interações com o meio. Temporárias são dinâmicas que se alteram constantemente, que acontecem no tempo, que surgem e desaparecem, que apresentam bordas indefinidas, que se misturam a matéria densa e fina que compõe paisagens.

Formações temporárias são planícies, montanhas, planaltos, terrenos irregulares que confundem e acalmam o olhar. São lugares, espacialidades transitórias, áreas sujeitas às variações do tempo, aos vendavais, às tempestades e aos dias de sol.

O lugar da representação, a área segura e estável se transforma, é agora observada sob o ponto de vista das dunas que se movem e mudam de posição a cada temporada. As paisagens já não são fotografias de tempos inertes congelados. As oscilações e as variações que lapidam as pedras à beira mar são aquelas que estão presentes também nas artes, em projetos e procedimentos que passam a assumir qualidades e especificidades do tempo e do espaço. A transitoriedade é um dos pontos de virada que acionará as práticas artísticas e incentivará dinâmicas e articulações entre os mais variados elementos. Pintar é também exercício da cor no espaço.

Quando o quadro pula da parede e quando as cenas se multiplicam em pedaços que se deslocam e compõem novas opções para o olhar, o espectador torna-se agente e elemento fundamental dos experimentos artísticos. E a partir de então ir ao teatro, a um museu ou a um espaço expositivo requer do espectador a pré-disposição de flutuar e encontrar novos pontos de fuga para o olhar. Olhar pode ser agora montar um quebra-cabeças como a possibilidade de compor múltiplas figuras, pode ser demorar-se em alguma forma já conhecida ou manipular um objeto. Pode ser que olhar seja caminhar por trajetos traçados por algum diretor ou curador de arte. O certo é que os sentidos podem agora experimentar olhares que escapam aos olhos e tocam em paisagens impensáveis.

Essa perspectiva que inclui o espectador de modo direto e até mesmo físico, diz respeito a um projeto de expansão da experiência artística e da articulação de condições instalativas que colocarão em questão a área de representação como espaço separado do meio.

Nesta seção proponho um olhar sobre a crise da representação e abordo o termo ambiental, utilizado tanto no contexto do teatro quando no das artes visuais, para me 
aproximar de premissas e qualidades que expandirão conceitos e noções, como a de acontecimento cênico e teatralidade, que serão observadas na próxima seção em diálogo com os Objetos Coreográficos.

Uma das principais condições apresentadas nas colocações desta seção diz respeito ao tempo, às experiências temporais que convidam o espectador à interações físicas ou promovem rearticulações na cena que levarão em consideração à transitoriedade dos elementos, das formas e agentes que compõem às paisagens que se formam diante ou na relação com o corpo.

Se a arte moderna dá ênfase às interações de elementos agregados em suportes e convoca o olhar para relações mais complexas com os trabalhos de arte, a arte contemporânea se lança ao desafio de experimentar propostas mais radicais que aparecem, muitas vezes, na rearticulação da percepção através do corpo, do contato com particularidades que se expõem nesse sistema complexo constituído por matéria e ligações sutis que estão em constante processo de organização.

\section{Transições}

No decorrer do século XX, pensamentos, teorias, práticas e paradigmas passam por revisões fundamentais que abrem conceitos e ordens instituídas para experiências temporais nas quais a imobilidade e a separação darão lugar a processos dinâmicos, instáveis e que se alteram constantemente. Um ponto de vista se multiplica em uma sucessão de pontos dispersos e difusos que permitem acesso ao mundo sob as mais variadas perspectivas.

O modernismo afirma e dá ênfase à autonomia dos trabalhos de arte em relação ao público ao mesmo tempo em que insinua variações e alternativas que provocarão novas aproximações entre obra e espectador. Se nas artes plástica o modernismo assume o interior de um cubo branco - espaços neutros nos quais eram expostos quadros e esculturas - como o lugar ideal para a apresentação dos trabalhos sem maiores interferências do meio, é também neste período que aparecerão formulações que tratarão de desmontar e promover as primeiras articulações que posteriormente abrirão quadros, esculturas e objetos para os mais variados experimentos. Nas artes cênicas a caixa preta, que dava suporte às mais diversas operações, muitas vezes pautadas em mecanismos ilusionistas, que destacavam limites entre obra e espectador, será o lugar de afirmação de preceitos modernistas ao mesmo tempo em que presenciará o surgimento de procedimentos que logo explodirão esquemas que criam 
universos e recortes espaciais autônomos para a obra e para o espectador.

Esses movimentos indicam importantes transformações que marcarão o que críticos e historiados de arte nomeiam e localizam como período de transição da arte moderna para a arte contemporânea.

As paisagens pautadas em paradigmas que constroem tempos distintos e espaços separados entre obra e espectador, tanto no contexto modernista do cubo branco quanto no da caixa preta, ganham tonalidades, matizes, pesos e proporções que revelam camadas de um ambiente dinâmico que se constrói na presença de materialidades. Molduras, pedestais, quarta paredes e demais convenções, que pareciam garantir a estabilidade do espaço intocável da obra, são colocados agora a mercê do tempo e de intempéries que provocam o desaparecimento momentâneo ou demorado dessas linhas que separam espaços e que se colocam diante dos olhos e da presença do espectador.

As paisagens passam a experimentar movimentações que ativarão a relação de elementos e qualidades que movimentarão o quadro, a cena, a escultura. Um espaço cinético passa a ser explorado e a área da representação, que se impunha como lugar separado do entorno, passa a experimentar dinâmicas que logo se expandirão para a área ocupada pelo espectador. Tempos paralelos, lugares distintos e uma moldura ou uma quarta parede que garantia a estabilidade do espaço intocável da obra passam a ser questionados. Ao espectador, que cabia a observação, mesmo que ativa, de ações que se desenvolviam em outro tempo e outro espaço, torna-se agente fundamental das propostas e de arte.

\section{Crise da representação}

Explorar espacialidades, limites, sentidos, possibilidades de percepção e a criação de espaços de partilha são algumas das premissas que cruzam os séculos e continuam presentes em discussões e procedimentos artísticos.

A crise da representação, anunciada no final do século XIX e início do século XX e ainda hoje investigada em procedimentos de arte contemporânea, explora condições espaciais capazes de acionar os mais variados elementos e agentes em diferentes procedimentos artísticos. Tais condições, que não são dadas a priori, mas que são criadas ao longo do evento artístico, surgem como dinâmicas de interação e promovem a expansão do fenômeno da arte para além de regras, padrões e referenciais instituídos. O fenômeno da arte, neste contexto, aparece como distribuição e organização de potencialidades que convocam a ação, o 
movimento e a transformação, o que coincide com propostas e produções artísticas no contexto atual.

Enquanto a arte moderna apresentou novas formas de pensar e sentir o mundo e buscou revelar aquilo que poderia ser a condição necessária ou a essência da pintura, como a planaridade - de acordo com Antônio Cícero (2005), a arte contemporânea se volta às possíveis relações do quadro ou do objeto de arte com o entorno e com o espectador. A arte moderna inicia um movimento de reconhecimento de elementos que tensionados parecem provocar a percepção. As pinceladas e materialidade do quadro evidenciam, aos poucos, aspectos e qualidades da pintura que logo avançarão pelo espaço. Já a arte contemporânea se empenhará na produção de experiências que questionam as áreas delimitadas de representação. O espaço da tela se estende, se mistura ao espaço do mundo, os lugares se somam, dialogam e promovem novas considerações a respeito do fenômeno artístico.

Neste ponto, problemáticas sobre a representação ganham destaque ao incentivarem questionamentos sobre limites e bordas. Ao questionarem as áreas de representação, as proposições artísticas parecem, em comum acordo, se ocuparem cada vez mais com aspectos que extrapolam os limites de uma área restrita de atuação e se lançam a movimentos ousados e dinâmicos que interpelam o espectador em seus sentidos e percepções. Esta dinâmica, hoje tão comum nos procedimentos artísticos parece ter sua origem em problemáticas que anunciam o fenômeno da arte como acontecimento que não está preso a uma determinada área, linguagem ou suporte. É neste contexto que surge uma pintura que já não cabe na área delimitada de uma tela e uma peça de teatro que ultrapassa os limites do palco, do texto ou da cena. Movimentos internos e próprios de cada manifestação artística percorrem o espaço e se fazem espaço enquanto exploram novas zonas de ação e sentidos.

Ainda sobre a crise da representação, a autora Juliane Rabentisch (2013) sugere um olhar para as problemáticas colocadas pela concepção modernista de autonomia estética a partir da noção de participação sob o ponto de vista da imersão, do mergulho do espectador em um tempo espaço independente. Noções modernistas previam o contato com a obra como ato de adesão a uma manifestação universal. "No âmbito de padrões influentes da estética modernista, que vão de Theodor W. Adorno a Michael Fried, participação em artes significa transcender a própria subjetividade e participar de algo que possui validade universal" (Rabentisch, 2013:89). ${ }^{149}$ Deste modo, a estética modernista aborda a produção artística como

\footnotetext{
${ }^{149}$ Texto original" "Whitin the framework of a very influential standart of modernist aesthetics, ranging from Theodor W. Adorno to Michael Fried, participating in arts means transcending one's subjectivity and partaking in something that possesses universal validy." (Rabentisch, 2013:89) ), no livro "Dance and Theory", Gabriele
} 
evento que transcende os aspectos materiais. O que entra em jogo aqui é uma relação na qual o espectador transcenderá sua posição de mero observador e será absorvido por uma composição que se manifesta de modo autônomo e universal.

\begin{abstract}
Esta é também a razão pela qual o sublime e não o belo é a categoria central da estética modernista. A arte não é mais definida como o produto de habilidades treinadas na aplicação de regras de simetria e proporção, mas um evento que transcende a lógica do domínio. Mas por mais atraente que esta ideia ainda possa ser silenciosa, deve-se levar em conta que a estética modernista entende o respectivo evento como uma manifestação da universalidade. (RABENTISCH, 2013:89, tradução nossa) $^{150}$
\end{abstract}

A participação em arte se afirma, sob essa perspectiva, como a partilha de uma universalidade, conforme pontua Rabentisch. E é deste modo que o "o observador, o ouvinte, o espectador, ou o leitor, ao se relacionar com o trabalho, supera sua própria contextualização empírica. Sob essas condições, um toque de utopia se acrescenta à experiência estética." (Rabentisch, 2013:90) $)^{151}$

Sob as condições apresentadas acima, as relações entre arte e espectador se definem a partir de premissas que pontuam valores e modulações pautadas em ideias conclusivas e acessíveis aos olhos e olhares que priorizam o universo proposto pela obra ao invés das relações possíveis geradas pelo contato com o trabalho.

Enquanto a estética modernista define sua produção como a construção de uma realidade autônoma e isolada do entorno, a arte contemporânea assume o indeterminado, as variações e as frestas que alteram constantemente suas bordas e confundem sua localização.

A noção de estética relacional, desenvolvida por Nicolas Borriaud, contribuiu significativamente para a superação de pontos de vista sobre o fenômeno da arte como a produção de áreas autônomas e aparece como alternativa para as premissas modernistas. Entretanto, a ênfase de Borriaud em aspectos sociais e políticos podem gerar novas conclusões sobre a experiência em arte. $\mathrm{O}$ autor levanta questões e sugere alternativas para as problemáticas apresentadas pela estética modernista ao mesmo tempo em que limita as diferentes possibilidade de compreensão sobre a participação em arte quando reduz a prática

Brandstetter e Gabriele Klein (org.).

150 Texto original: "This is also the reason why the sublime and not the beautiful is the central category for modernist aesthetics. Art is no longer defined as the product of trained skills applying rules of symmetry and proportion, but as an event that transcends the logic of mastery. But however appealing this Idea still might be, it has to be taken into account that modernist aesthetics understands the respective event as a manifestation of universality." (Rabentisch, 2013:89).

${ }^{151}$ Texto original: "the beholder, listener, spectator, or reader, by relating to the work, likewise overcomes her own empirical situatedness. Under these conditions, a tinge of utopia accrues to aesthetic experience."

(Rabentisch, 2013:90, tradução nossa) 
artística a um instrumento de prática política e social. Suas considerações abordam a participação social sem com isso instaurarem diferenciações estéticas que operem para além dos vínculos institucionais, como pontua Rabentisch (2013).

A autora explica as contradições e paradoxos que permeiam a noção de estética relacional proposta por Borriaud:

\begin{abstract}
Em outras palavras, em vez de afirmar a autonomia da arte a fim de representar uma utopia inatingível para qualquer política concreta, a arte se torna um instrumento de realização prático- política do que é micro-topicamente possível: ajudar na obtenção de participação social. Com efeito, essa mudança teórica apenas implementa uma superação paradoxal da arte na vida que mais uma vez cimenta a diferença entre a prática ideal de arte e a realidade menos-que-ideal. No entanto, esta diferença já não pode ser conceitualizada como diferença estética, mas reinstala-se como diferença social. (RABENTISH, 2013:90, tradução nossa) ${ }^{152}$
\end{abstract}

O que Rabentisch discute é a redução dos processos artísticos a considerações sobre relações e aspectos políticos que novamente limitariam a investigação do que a participação em arte pode vir a ser. Concepções alternativas sobre os desdobramentos possíveis de uma relação estética são transformados em afirmações que, ao localizarem a arte como prática política ou de participação social, freiam ou até mesmo bloqueiam a elaboração de conceitos alternativos sobre a produção em arte.

Mesmo que o conceito de política esteja pautado em noções abrangentes e que levam em consideração o ato político como ação vinculada a percepção e ao modo como criamos relações, ainda assim qualquer localização parece limitar a possibilidade de investigação dos fenômenos para além de referenciais já conhecidos.

Jacques Rancière discute a política sob o ponto de vista do sensível, da partilha de sensibilidades, e levanta também importantes considerações sobre a arte como campo político no qual a provocação da percepções gera novas possibilidades de relação com o entorno.

Entretanto, é importante observar o alerta da autora Juliane Rabentisch no que diz respeito a construção de entendimentos estáveis que estimulam compreensões e abordagens repetitivas. Se as contribuições dos autores como Borriaud e Rancière são fundamentais na ativação de perspectivas e reflexões que ampliam as possibilidades de se pensar a relação e a produção em arte, há de se considerar que uma investigação sobre a experiência ou

\footnotetext{
152 Texto original: In other words, instead of asserting art's autonomy in order to represent a utopia unattainable to any concrete politics, art is to become an instrument of the practical-political realization of what is microtopically possible: assisting in achieving social participation. In effect, however, this theoretical shift merely implements a paradoxical sublation of art into life that once again cements the difference between the ideal practice of art and less-than-ideal reality. However, this difference can no longer be conceptualized as aesthetic difference, but reinstalls itself as social difference. (Rabentisch, 2013:90).
} 
participação estética está comprometida com qualidades e referenciais oscilatórios que se manifestam em diferentes níveis. As tramas que acionam relações agem nos ossos, nas organizações sociais, na sensação da pele e em qualidades invisíveis que se manifestam em nevoeiros que desorientam associações e identificação de terrenos. Experiências estéticas são fenômenos que aceitam múltiplas orientações e sentidos, são atos gerados em ligações e emaranhados ambientais e linhas fugidias que se apresentam e somem em um espaço de heterotopias.

Sob este ponto de vista, a observação de diferentes pensamentos e discussões é fundamental para a visualização do fenômeno da arte sob uma perspectiva ampla e difusa na qual tensões, elementos e agentes se interligam e promovem a possibilidade de ativação de paisagens complexas e efêmeras que estão em constante processo de criação e desaparecimento. A produção desses movimentos coincide com uma expansão que fura as bordas do evento e emancipa a produção de arte de modelos e parâmetros que regulam o olhar e os sentidos.

As complexidades e dinâmicas das relações que se entrelaçam em considerações sobre possibilidades de experiência estética são assim descritas por Rabentisch:

\begin{abstract}
Arte, em outras palavras, não é objetivo dado mas algo que passa a existir em virtude das experiências que são comunicadas - o que também significa que a diferença entre estética e não-estética não é mais concebida como aquela entre o que está contido no trabalho e o que é externo a ele. De acordo com este ponto de vista, a estética não constitui de modo algum um domínio especial separado da não-estética. A estética, ao contrário, existe no evento ou no processo de se tornar estética. A estética e a não-estética consistem em uma transformação reflexiva da não-estética. (RABENTISCH, 2013:91, tradução nossa). ${ }^{153}$
\end{abstract}

Esse criar e apagar linhas aparece em experiência que flutuam entre noções, conceitos e articulação de planos e materialidades que legitimam a arte em sua condição dinâmica e transitiva. Esse diálogo que propõe aberturas nos processos artísticos trata ainda de condições e experiências que dão destaque às interações entre elementos nas quais corpo e espaço aparecerão como instâncias frágeis e relacionais que se manifestam em variações e possibilidades ambientais.

Mover, ativar e considerar a presença do corpo na relação com o ambiente passam a ser

\footnotetext{
${ }^{153}$ Texto original: "Art, in other words, is not an objective given but comes into existence in and by virtue of the experiences it releases - which also means that the difference between the aesthetic and the non-aesthetic is no longer conceived as that between a self-contained work and what is external to it. According to this view, the aesthetic does not constitute a special domain separate from the non-aesthetic at all. The aesthetic exist instead in the process, or the event, of becoming aesthetic. The aesthetic and the non-aesthetic consists in a reflexive transformation of non-aesthetic." (Rabentisch, 2013:91)
} 
atos imprescindíveis em diferentes projetos e especulações sobre o fazer artístico. Corpo e espaço iniciam um intenso diálogo que promoverá as mais variadas possibilidades de observação e prática dos eventos artísticos. Uma constelação de agentes interage entre si provocando o olhar para a percepção de movimentos sutis que aparecem em intervalos.

Essa ativação coloca em evidência o corpo, a presença de variações que se manifestam em detalhes e diferenças que são acentuadas em ações que levam em consideração particularidades da matéria, relações, acasos e imprevisibilidades que decorrem de contatos e interferências ambientais.

O corpo ganha importância e se torna centro de investigações práticas e teóricas, sobretudo, a partir da década de 50, quando as artes se apropriam de discussões que apontam para a dissolução das relações dicotômicas entre sujeito, objeto e espaço. Correntes pósestruturalistas, no contexto da filosofia, incentivaram importantes mudanças de referenciais que alteraram radicalmente noções e conceitos sobre conhecimento e percepção que se refletiram em diferentes campos, sobretudo, nas artes. A experiência do sujeito passa a ser compreendida como dinâmica e é neste contexto que as vanguardas artísticas do início e meados do século XX irão propor uma dinamização dos processos e propostas artísticas. A ideia de uma obra ambiental, no qual dinâmicas aproximam obra e espectador, passa a compor a paisagem de inúmeras propostas de arte a partir de então.

$\mathrm{Na}$ dinamização da pintura surge a action paiting, a performance, o happening, na dinamização das esculturas surgem os ambientes, as instalações que reconfiguram o espaço e alteração a posição do espectador.

O reconhecimento do espectador parece ser uma das condições fundamentais nesse movimento de diálogo da produção artística com o entorno e a chave de acesso a novos campos de investigação.

A pintura que antes absorvia e solicitava uma participação imersiva do espectador, a partir de narrativas ou efeitos ilusionistas, aos poucos experimenta novas condições e revelase enquanto linguagem em movimento, matéria e presença.

O foco se desloca da compreensão de discursos visuais ou teóricos e se dirige a uma multiplicidade de relações que dinamizam o fenômeno da arte e acionam vínculos com o espectador. O que está em pauta não é a apreensão de um significado, mas os movimentos de interação que provocam diferentes experiências.

A desarticulação do tempo e do espaço, das linhas narrativas regulares e cronológicas promovem descontinuidades que abrem e ampliam o campo perceptivo para interferências e organizações que não dependem de estruturações narrativas ou lineares. A percepção avança 
para o corpo, para a matéria e se desvincula dos esquemas que priorizam discursos regulares e previsíveis. A coexistência de múltiplos aspectos é revelada em experiências que inviabilizam a possibilidade de retenção de pontos de vista estáveis.

O corpo gira, desliza e se move em uma rede de relações que evidenciam avessos, memórias, sons, tonalidades, cores, texturas em um amplo campo de ação no qual os mais variados estímulos interagem entre si. O corpo percebe.

A percepção pode ser compreendida como a própria consciência sobre as coisas e não como propriedade que precede ao ato. Perceber é entrar em relação, é movimentar-se. E é deste modo que a percepção aparece como um ato corporal. Ao perceber o corpo é convocado ao movimento, à ação.

Esta experiência pode ser melhor compreendida a partir das palavras de Maurice Merleau- Ponty:

\begin{abstract}
A experiência revela sob o espaço objetivo, no qual finalmente o corpo toma lugar, uma espacialidade primordial da qual a primeira é apenas o invólucro e que se confunde com o próprio ser do corpo. Ser corpo, nós o vimos, é estar atado a um certo mundo, e nosso corpo não está primeiramente no espaço: ele é no espaço" (MERLEAU-PONTY, 1999:205)
\end{abstract}

A percepção, deste modo, manifesta-se como evento da corporeidade, como relação estabelecida, e não como uma representação analítica e racional. Merleau-Ponty (1999) critica a supremacia da razão e anuncia que o conhecimento do mundo se dá através de experiências que desenham continuamente um novo corpo. Corpo este que aparece como o próprio lugar do conhecimento.

Tal abordagem referente à ação, à percepção e ao corpo apresenta uma noção de espaço que entra em conflito com aquela adotada pela física clássica. O espaço surge agora como instância, trânsito e interação e não como um território previamente mensurado e delimitado por regras e medidas, como queria a noção euclidiana de lugar.

A partir das noções e conceitos apresentados acima, é possível dizer que um campo de caráter efêmero e processual é inaugurado. O espaço artístico se transforma em um lugar que pretende alterar dispositivos que costumam regular a percepção e os sentidos.

\title{
Espaços
}

No que diz respeito ao espaço, é importante mencionar as contribuições de Appia e 
Craig na abertura e mobilidade do espaço cênico. Essas transformações auxiliam na observação da noção de ambiental que será abordada em seguida.

Adolphe Appia e Gordon Craig, logo no início do século XX, apresentam importantes contribuições para o teatro moderno ao darem ênfase aos aspectos materiais que compõem o campo de ação cênico. A ativação do espaço a partir da dinamização de objetos, corpos, luzes e demais elementos que constituem o campo teatral, colocam o ator diante de materialidades que já não são passivas ou anteparos de ações, mas antes agentes em uma complexa espacialidade composta por volumes, texturas, cores, camadas e intensidades que provocam a observação do teatro sob uma perspectiva multidimensional e dinâmica. A cena se abre, apresenta-se como profundidade, ângulo e peso.

Adolphe Appia, no ano de 1921, anuncia "Nós estamos finalmente livres"154. De acordo com Barbara Gronau, sua euforia anuncia uma mudança de paradigma na qual a dimensão performativa do espaço é apresentada.

Ele (Appia) realiza uma mudança da lógica bidimensional da fase ilusionista das imagens do palco para espaços dinâmicos de ação. Os novos espaços cênicos surgem da interdependência da arquitetura e do movimento, o que significa: a partir da interação de espaço, corpos e ação. (GRONAU, 2010:255) ${ }^{155}$

Appia antecipa uma discussão que a partir da segunda metade do século XX surgirá apoiada por conceitos ou noções como performatividade e teatralidade, que tratam das dinâmicas, dos diferentes modos de fazer e ver.

O projeto Scene, de Gordon Craig, abordado detalhadamente pelo crítico e pesquisador Luiz Fernado Ramos (2014) no texto ${ }^{156}$ "O Projeto Scene de Gordon Craig: história aberta à revisão", é fundamentado em mecanismos que movimentam a cena a partir de telas móveis e articuláveis. Essas telas foram, de acordo com Ramos, "um mecanismo poético para criar $a$ nova arte do teatro", além de tornarem as encenações mais baratas. Craig interfere nas relações espaciais com suas estruturas cinéticas que reposicionam elementos na cena e o olhar do espectador.

\footnotetext{
${ }^{154}$ Disponível no texto "Dynamische Räume", de Barbara Gronau, no livro "Theater Ohne Fluchtpunkt", 2010:255.

${ }^{155}$ Texto original: "Er vollzieht sich als Abkehr von der zweidimensionalen Logik des illusionistischen Bühnenbildes zugunsten dynamischer Handlungsräume. Die neuen Bühnenräume erwachsen aus der Interdependenz von Architektur und Bewegung, das heiß aus dem Zusammenspiel von Raum, Körpern und Handlung." (Gronau, 2010:255)

${ }^{156}$ Luiz Fernando Ramos - "O Projeto Scene de Gordon Craig: história aberta à revisão".

Rev. Bras. Estud. Presença, Porto Alegre, v. 4, n. 3, p. 443-462, set./dez. 2014.

Disponível em: <http://www.seer.ufrgs.br/presenca
} 
As contribuições de Craig e Appia destacam a ação, as relações entre elementos e a possibilidade de construção de espacialidades complexas que reverberam para além de convenções que associam o teatro ao texto e às estruturas narrativas dramáticas. As lógicas temporais e a reestruturação dos elementos da cena convidam o espectador para experiências que levam em consideração camadas mais complexas do evento. Cores, volumes e materialidades geram novas zonas de ação entre palco e público. O espaço ganha intensidade, respira, ganha tonalidades e qualidades ambientais.

Qualidades ambientais são instabilidades, indeterminações, imprevisibilidades e as dinâmicas que negociam com diferentes elementos e situações. Qualidade ambiental é mudança de perspectiva e a consideração de pontos de vista musculares, ósseos, orgânicos, auditivos, visuais e táteis. É confluência que gera oscilações, é a aranha que baba e tece a teia ao mesmo tempo.

Essas qualidades ambientais, verificáveis em procedimentos de William Forsythe, coincidem com abordagens instalativas nas quais corpo, espaço e percepção produzem formações temporárias. Essas paisagens frágeis podem ser observadas sob o ponto de vista de uma condição teatral que verifico em produções que não se restringem à prática daquilo que é institucionalizado ou classificado como teatro.

A noção de ambiental prevê incursões espaciais detectáveis na produção de arte contemporânea em experimentos temporários e inclassificáveis.

Uma noção que auxilia na observação do teatro e da produção artística como terreno em expansão e em dialogo com o ambiente e com as texturas espaciais é o conceito de ambiental.

O conceito de ambiental aparece como condição na qual os fenômenos artísticos se apresentam como potencialidade de relação, como compartilhamento de espaço e como surgimento de pontos de observação múltiplos e dinâmicos. Um evento sem ponto de fuga, sem um orientador fixo que garanta o reconhecimento de fórmulas e padrões instituídos. Participar não tem aqui a mesma conotação de participação colocada por Juliane Rabentish no contexto da arte moderna e fundamentada na ideia de imersão, de participar e ser absorvido por uma obra que se coloca no mundo como construção paralela. A participação aqui diz respeito ao agir com, ao acionamento de forças que são geradoras de experiências e situações na produção de arte. Esse agir, entretanto, não está condicionado apenas às propostas que solicitam a presença física do corpo do espectador, mas antes na dinamização e nas mudança de padrões que favorecem alterações nos sentidos.

A ideia da obra como processo e não como objeto acabado em si confere ao evento de arte condições transitivas que aparecerão em aberturas e passagens que se comprometem com 
a inclusão do espectador, seja de modo direto, a partir de sua presença física, ou na provocação da sua percepção.

Nos exemplos e considerações a seguir focarei em propostas que chamam o espectador para relações corporais como modo de observar qualidades e pensamentos que surgem de interações físicas e espaciais.

Richard Schechner e Hélio Oiticica apresentam importantes qualidades ambientais ao se apropriarem do termo ambiental em suas produções.

Schechner, na introdução da edição expandida do livro Environmental Theater, informa que o termo Environmental, usado em seus trabalhos, sobretudo na década de 70 , vem do conceito de Allan Kaprow, que em 1966 escreveu o livro Assemblages, Environments $e$ Happenings. A noção de Environmental no contexto de Kaprow se relaciona com o mundo da pintura e é a partir daí que Schechner irá colocar tal noção em diálogo com a perspectiva teatral. $\mathrm{O}$ autor faz ainda algumas considerações sobre a sua concepção de ambiental:

Os significados teatrais e ecológico dos ambientes não são antitéticos. Um ambiente é o que envolve, sustenta, envolve, contém, aninha. Mas ele é também participativo e ativo, uma concatenação de sistemas vivos. Em termos de planeta terra, o ambiente é o lugar onde a vida acontece. $\mathrm{O}$ ambiente da terra é afetado por seres vivos (bem como por eventos naturais não vivos, como erupções vulcânicas, tempestades, inundações, marcas solares, etc.) (SCHECHNER, 1994:5, tradução nossa) $)^{157}$

A noção de teatro ambiental, de Schechner, implica uma série de noções que são estruturadas a partir de um texto seu de 1967, Six Axioms for Environmental Theater, Seis Axiomas para um Teatro Ambiental, que foi republicado no livro Environmental Theater, de 1994. Esse livro apresenta uma reflexão sobre a noção de ambiental a partir de temas como espaço, participação, nudez, performer, xamã, terapia, texto, grupos e diretor.

Das orientações previstas em seu texto de 1967 e das noções que ele adiciona a sua edição mais recente, destaco considerações sobre o espaço e sobre a participação.

Uma das bases principais do conceito de Environmental Theater, de Schechner, é a rearticulação espacial a partir da afirmação de relações e perspectivas que geram encontros e fusões do trabalho com o espectador. Como comenta o autor: "Em uma palavra, ambientes ecológicos ou teatrais podem ser imaginados não só como espaços, mas como participantes

\footnotetext{
157 Texto original: "The theatrical and the ecological meaning of environments are not antithetical. An environment is what surrounds, sustains, envelope, contains, nests. But it is also participatory and active, a concatenation of living systems. In terms of the planet earth, the environment is where life happens. The earth's environment is affected by living beings (as well as by non-living natural events such as volcanic eruptions, storms, floods, sunspots, etc.)." (Schechner, 1994:5)
} 
ativos em sistemas complexos de transformação. (Schechner, 1994:5)." ${ }^{\text {"158 }}$ Schechner chama a atenção para a observação do fenômeno teatral sob uma perspectiva ecológica na qual diferentes agentes de um sistema se relacionam e se transformam.

O autor afirma ainda que o Environment Theater trata de aspectos da direção teatral, da composição de trabalhos, da organização do espaço, da formação ou termino de grupos e é também um manual de treinamento para o performer, ou o atuante, baseado em práticas corporais de relaxamento, respiração e produção de sons.

No texto "Six axioms for Environmental Theater", o autor descreve os seis axiomas: o primeiro se refere ao evento teatral como um conjunto de negociações relacionadas; o segundo diz que todo o espaço é aproveitado pela performance; o terceiro afirma que o evento teatral pode acontecer tanto em um espaço totalmente modificado quanto em um espaço que é "fundado", no quarto Schechner diz que o foco é flexível e variável; o quinto é sobre os elementos que constituem a produção teatral e neste axioma o autor diz que todos os elementos falam sua própria língua; o sexto e último axioma afirma que o texto não deve ser nem o ponto de partida e nem o objetivo de uma produção e que é possível que não exista texto verbal.

Com esses seis axiomas Richard Schechner faz um panorama de condições e situações que definem a sua noção de um teatro ambiental. Este texto, que foi escrito cinco anos antes de Schechner terminar o livro "Environmental Theater", foi a sua primeira investigação do que viria a ser a sua noção de teatro ambiental. Os aspectos destacados pelo autor, nesse texto, dão ênfase às relações ativas entre os elementos que constituem as suas abordagens. Schechner explica:

\footnotetext{
Nem ambientes ecológicos nem performances são passivos. Eles são agentes de interação em eventos que de modo orgânico ocupam completamente espaços vivificados. O ambiente da performance é uma "posição" no sentido político, um "corpo de conhecimento" no sentido acadêmico, um " lugar verdadeiro", no sentido teatral. Assim, encenar uma performance "ambientalmente" significa mais do que simplesmente mover-se para fora do proscênio ou para fora da arena. Uma performance ambiental é aquela em que todos os elementos ou partes que compõem a performance são reconhecidos de modo vivo. "Estar vivo" é mudar, desenvolver, transformar; ter necessidades e desejos; até mesmo, potencialmente, adquirir, expressar e usar a consciência. (SCHECHNER, 2004: 5) ${ }^{159}$
}

\footnotetext{
${ }^{158}$ Texto original: "In a word, environments ecological or theatrical can be imagined not ony as spaces but as active players in complex systems of transformation." (Schechner, 1994:5).

${ }^{159}$ Texto original: "Neither ecological nor performance environments are passive. They are interactants in events organically taking throughout vivified spaces. A performance environment is a "position" in the political sense, a "body of knowledge" in the scholarly sense, a "real place" in the theatrical sense. Thus, to stage a performance "environmentally" means more than simply to move it off of the proscenium or out of the arena. An environmental performance is one in which all the elements or parts making up the performance are recognized
} 
No segundo axioma, que trata diretamente do espaço, a concepção ambiental proposta por Schechner fica clara quando ele fala sobre a superação de divisões entre a área de atuação e da área do espectador. Os campos se misturam, se tocam e formam um campo amplo e único no qual estão previstas trocas e contatos diretos.

Neste ponto as considerações de Schechner sobre um teatro ambiental encostam nas problemáticas e propostas incentivadas pelos experimentos de Hélio Oiticica.

Propositor de experiências que farão parte de um projeto ambiental, Oiticica apresenta a sua noção de ambiental quando promove alterações estruturais que libertarão seus trabalhos da dependência de suportes e configurações espaciais que separam a obra do ambiente. Uma obra ambulatória e em constante diálogo com o entorno fundamentará as propostas ambientais de Hélio Oiticica. Vemos surgir aqui também uma paisagem em expansão no qual o espectador é convidado a participar de ações que fundamentarão a produção de seus trabalhos.

A partir dos seus trabalhos conhecidos como Metaesquemas, que foram criados no período concreto quando Oiticica ainda investigava estruturas geométricas, o artista se empenhará na criação de propostas espaciais e instalativas que descolarão de uma vez por todas as linhas e as cores do suportes tradicionais da pintura e do quadro. Com os Núcleos e os Penetráveis as manifestações ambientais passam a fazer parte de um programa no qual a participação do espectador é efetivada em experiências físicas e sensoriais com cores e movimentos. As relações plásticas e físicas que são criadas confirmam pressupostos ambientais colocados por Oiticica.

\footnotetext{
As descobertas realizadas no desenvolvimento dos Penetráveis passam a ser a coluna das obras posteriores do artista, como os Bólides, os Parangolés e os Ambientes. É com os Penetráveis que Oiticica corporifica a cor e temporaliza no espaço a estrutura. Transformando as relações plásticas em vivencias os Penetráveis superam as questões construtivas modernas. (JEZZINI, 2012) ) $^{160}$
}

Helio Oiticica comenta o surgimento de novas condições estéticas a partir de uma perspectiva mais ampla na qual os desdobramentos dos trabalhos no espaço e as interações

alive. To "be alive" is to change, develop, transform; to have needs and desires; even, potentially, to acquire, express, and use consciousness." (Schechner, 2004:5)

${ }^{160}$ No texto: "A arte brasileira no espaço e no sentido da construtividade", Jhanainna Silva Pereira Jezzini, 2011. Disponível no link: http://www.revistaohun.ufba.br/pdf/janaina.pdf. Acesso em maio de 2015. 
entre elementos denota uma das principais características do que serão suas obras ambientais. De acordo com Oiticica:

\begin{abstract}
Como está tudo tão claro agora: que a pintura teria de sair para o espaço, ser completa, não em superfície, em aparência, mas na sua integridade profunda. Creio que só partindo desses elementos novos poder-se-á levar adiante o que começaram os grandes construtores do começo do século (Kandinsky, Malévitch, Tatlin, Mondrian etc.), construtores do fim da figura e do quadro, e do começo de algo novo, não por serem "geométricos", mas por que atingem com maior objetividade o problema da não-objetividade. (OITICICA, 1986: 27)
\end{abstract}

Celso Favaretto (2000) comenta ainda a relação entre o desinteresse de Oiticica por estruturas orientadoras e o seu projeto ambiental, que é visto pelo autor como uma espécie de antiarte no que se refere à negação de padrões estruturais e estéticos que determinavam a noção de arte. "A antiarte ambiental é consequência da expansão das operações construtivas ao espaço das vivências e exemplo da nova situação estética" (Favaretto, 2000:123).

Obra ambiental, instalação ou condição instalativa são algumas das noções abordadas nesta pesquisa que favorecem a observação da produção em arte sob uma perspectiva ampla e complexa na qual a cena como imagem, como plano bidimensional, como tela é superada dando lugar a construção de ambientes que se formam no cruzamento de forças e potencialidades, de terceiras e quartas dimensões na qual público e obra se entrelaçam.

Nesta relação entre obra e espectador, sob o ponto de vista da interação de materialidades e qualidades que reverberam no corpo, apresento, a seguir, considerações sobre os artistas Lygia Clark e Helio Oiticica. A observação do percurso de Clark e Oiticica contribuem com observações e exemplos que discorrem sobre a crise da representação, a inauguração de novas relações entre obra e espectador ao mesmo tempo em que tratam do corpo em experiências nas quais a matéria e os impactos físicos estimulam a percepção e a produção de espaços ou heterotopias que interligam e acionam múltiplos agentes.

A questão da materialidade e os aspectos perceptivos que se manifestam no corpo em suas interações espaciais será tema da seção seguinte, na qual destaco relações entre ações de vanguarda, sobretudo do minimalismo, com alguns dos Objetos Coreográficos de William Forsythe.

\title{
Hélio e Lygia
}

As investigações experimentais de Hélio Oiticica e Lygia Clark, que chamo aqui de arquiteturas teatrais, estimularam novas perspectivas para a prática e o pensamento da arte e 
formam o escopo principal das problemáticas que destaco nos trabalhos de William Forsythe.

Enquanto Forsythe parte da dança e encontra pontos, linhas, orientações geométricas e articulações espaciais como lugar de potência e provocação de experiências, Oiticica e Clark investigam a zona de representação do quadro, desdobram o plano e chegam no corpo, no movimento e na dança como meio e fim do acontecimento artístico. Tanto Forsythe quando Clark e Oiticica pesquisam a construção de ambientes e interações que o teatro, como espaço de relações, encontros e partilhas, cria ao ultrapassar as delimitações que o encerram ao contexto de uma cena, por exemplo. A presença e a transfiguração do espaço coincidem com estímulos fundamentais presentes nas investigações e propostas desses artistas.

O que legitima o acontecimento da arte não se encerra aos registros ou às referências materiais desta ou daquela linguagem. Não é o quadro, não é a escultura, não é o pintor, não é a tinta, não é a tela, não é o palco, não é o bailarino, não é o passo. O que entra em jogo é a multiplicidade dos corpos e os trânsitos que criam espaços e percursos.

No Brasil, o início da arte contemporânea coincide com o surgimento de movimentos, como o Neoconcretismo, de 1959, que questiona os limites entre as linguagens artísticas propondo expressões que ultrapassam as definições de pintura e escultura, principalmente. As experimentações e as relações entre obra e espectador são os principais focos de interesse. Trabalhos que incentivam estímulos sensoriais ou o pensamento são tendências que exigem do espectador interpretações e a criação de sentidos. A partir de então se torna impossível pensar a arte apenas com base no valor visual ou nas classificações habituais. Questiona-se a própria definição de arte.

As novas orientações artísticas articulam diferentes linguagens, como dança, música, pintura, teatro, escultura, literatura e procuram aproximar arte e vida, favorecendo o contato da arte com a natureza, com a realidade urbana, com a arquitetura e com as tecnologias.

A produção do artista Helio Oiticica, no contexto deste estudo, contribui para o mapeamento de pensamentos e transformações que coincidem com os interesses de William Forsythe. Do abandono da tela como suporte da pintura para experiências que exigem a presença ativa do corpo do espectador, como os Parangolés, Helio Oiticica percorre uma trajetória que reforça e confirma o interesse pela desestabilização de sentidos e padrões.

Enquanto Oiticica parte de estruturas planares e geométricas e encontra a dança - o corpo em movimento e em relação, como lugar de acesso aos seus trabalhos de arte, Forsythe parte das estruturas rígidas e codificadas do balé e chega nos ambientes abertos e dirigidos à interação do espectador - os Objetos Coreográficos. 


\section{Arquitetura teatral}

$\mathrm{O}$ termo arquitetura teatral, no contexto desta pesquisa, se aproxima daquilo que o artista Helio Oiticica chamou de Manifestações Ambientais, a partir da década de 60. O conceito "ambiental" presente nos trabalhos e nos textos do artista coincide com uma abordagem e visão ampliadas do fenômeno artístico, no qual o uso de diferentes meios e linguagens favorece diferentes possibilidades participativas. A noção de arquitetura teatral será então abordada sob o ponto de vista da criação de ambientes que estimulam experiências e provocam a percepção do espectador. Lugar que se constrói enquanto o sujeito se desloca, percorre e cria espaços. Essa dinâmica entrelaça conceitos que categorizavam e delimitavam distintas posições para aquilo que se convencionou chamar de obra de arte e espectador.

No decorrer da produção de Oiticica é possível perceber que a prática da arte vai ganhando uma perspectiva cada vez mais pautada em experimentos que buscam acionar o espectador. $\mathrm{O}$ acontecimento artístico passa a compreender uma esfera mais abrangente e complexa na qual o diálogo entre elementos e agentes se intensifica.

Seus trabalhos incentivam propostas, trocas, aberturas e intercâmbios que desenham um novo lugar para o acontecimento da arte. Surge um terreno no qual as relações e interações são ressaltadas em detrimento das formas.

\section{Helio Oiticica}

Hélio Oiticica (1937- 1980), nasceu no Rio de Janeiro, Brasil. Originário das artes visuais, o artista é um dos nomes mais importantes no que diz respeito às propostas de interação. Seus interesses se centralizam na criação de trabalhos que estimulam a ação do espectador em suas relações como o entorno, sugerindo as obras ambientais.

Em 1954, Oiticica inicia estudos de pintura e desenho e escreve seu primeiro texto sobre artes plásticas. A partir daí textos e reflexões acompanharão a sua produção. Participa do Grupo Frente em 1955 e 1956. Em 1957, inicia suas pinturas geométricas de guache em cartão, que nos anos 1970, ele dará o nome de Metaesquemas. Segundo Oiticica, essas pinturas geométricas já apresentam o conflito entre o espaço pictórico e o espaço extrapictórico, o que o levou a superação do quadro como suporte da pintura. 


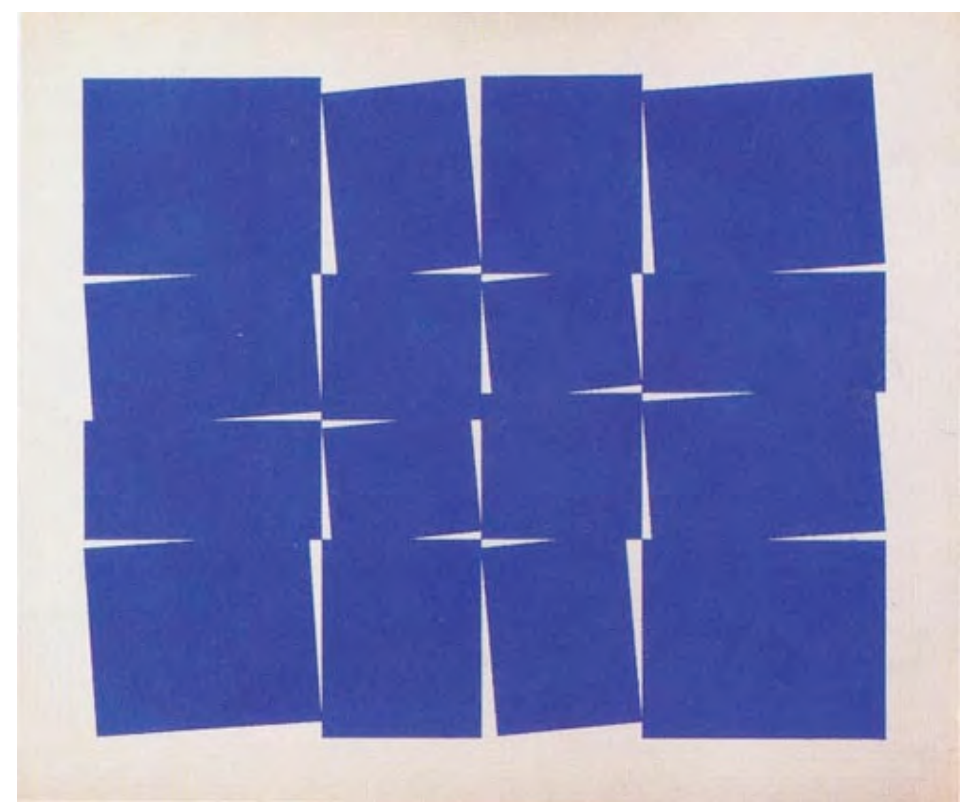

Metaesquema

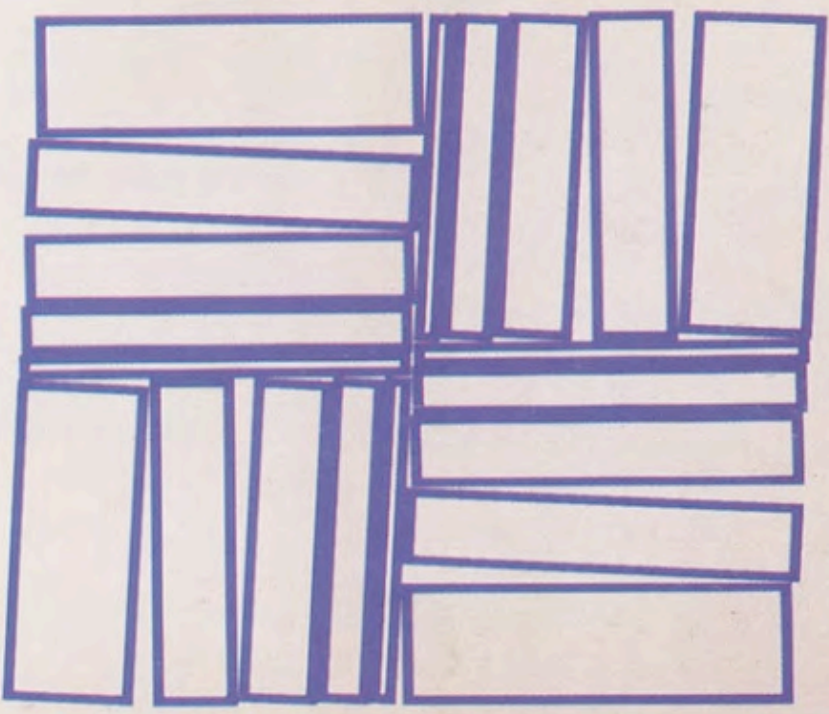

Metaesquema 


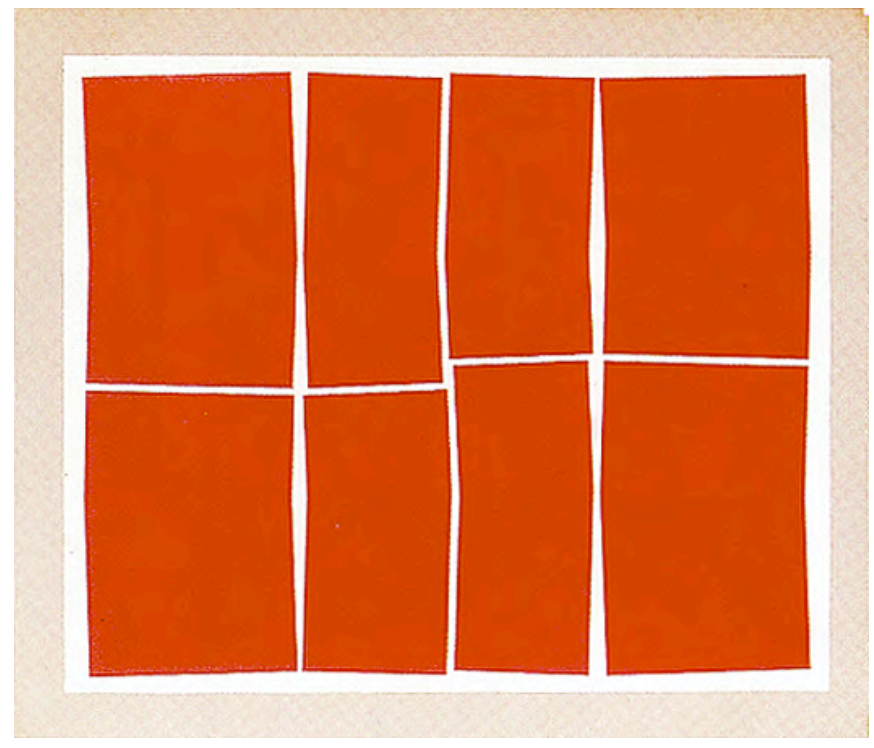

Metaesquema

Com a série Invenções (1959-1962), pequenos quadrados monocromáticos, o artista inicia a transição da tela para o espaço antes destinado ao público, que acontecerá, em 1959, com as suas primeiras obras tridimensionais: os Bilaterais - chapas monocromáticas pintadas suspensas por fios de nylon - e os Relevos Espaciais.

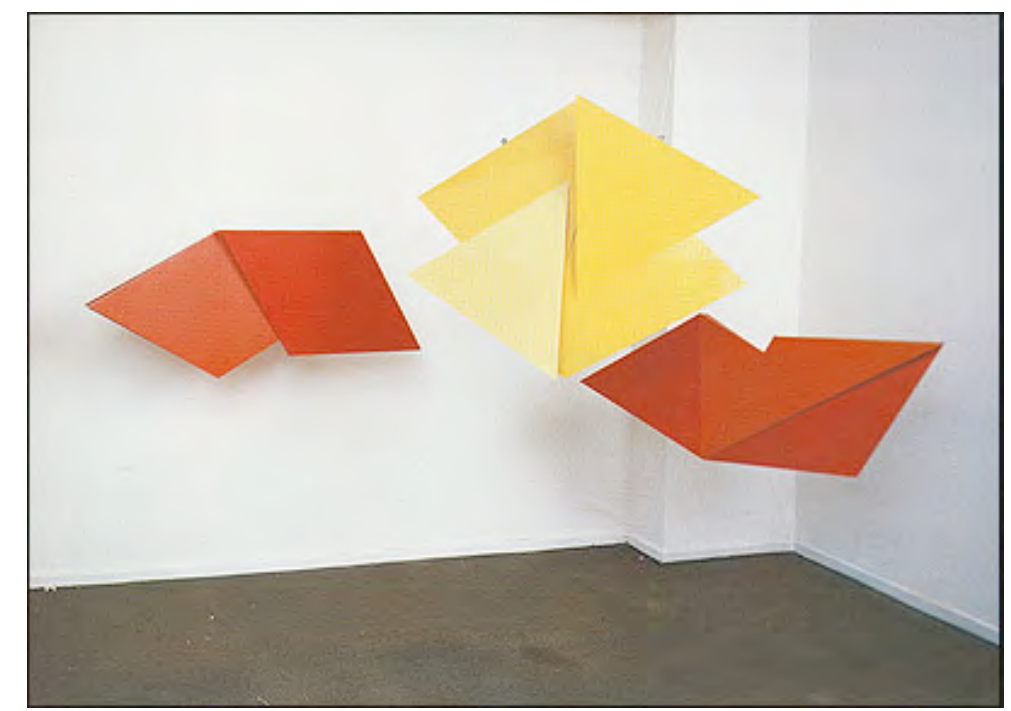

Relevo Espacial, enciclopédia Itaú Cultural

Em 1960, Hélio Oiticica cria os primeiros Núcleos, também denominados Manifestações Ambientais e Penetráveis - placas de madeira pintadas com cores quentes penduradas no teto por fios de nylon. Nesses trabalhos, o deslocamento do espectador e a movimentação das placas integram o acontecimento da obra.

Em 1963 surgem Os Bólides, as primeiras estruturas manuseáveis através das quais o 
espectador é convidado à experiência da cor como matéria e estímulo sensorial.

Os primeiros Bólides são recipientes que contêm pigmento de diferentes cores. Surgirão, a seguir, variações de Bólides, também chamados de Transobjetos, compostos por diferentes materiais, como conchas e latas.

A potência dos materiais em fundar novas relações entre o espectador/participador e o mundo é ativada através da estrutura Bólide, que aglomera a matéria e estimula a percepção para o já conhecido e disperso no ambiente. Pode-se dizer que os Bólides são estruturas compostas por elementos e materiais que condensados ou agrupados fundam diferentes percepções sobre o estar das coisas.

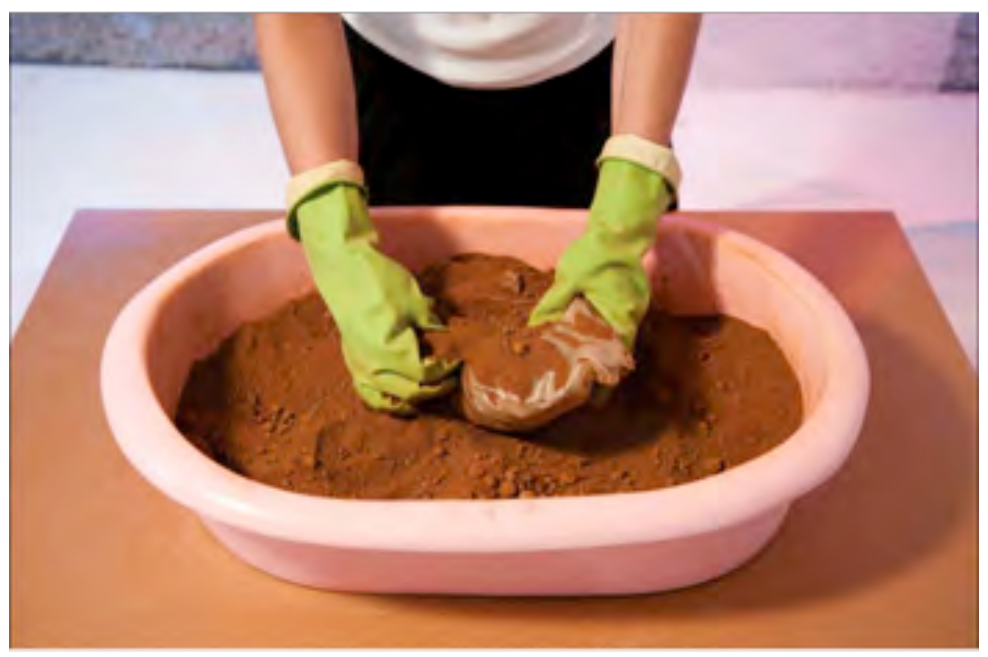

Bólide

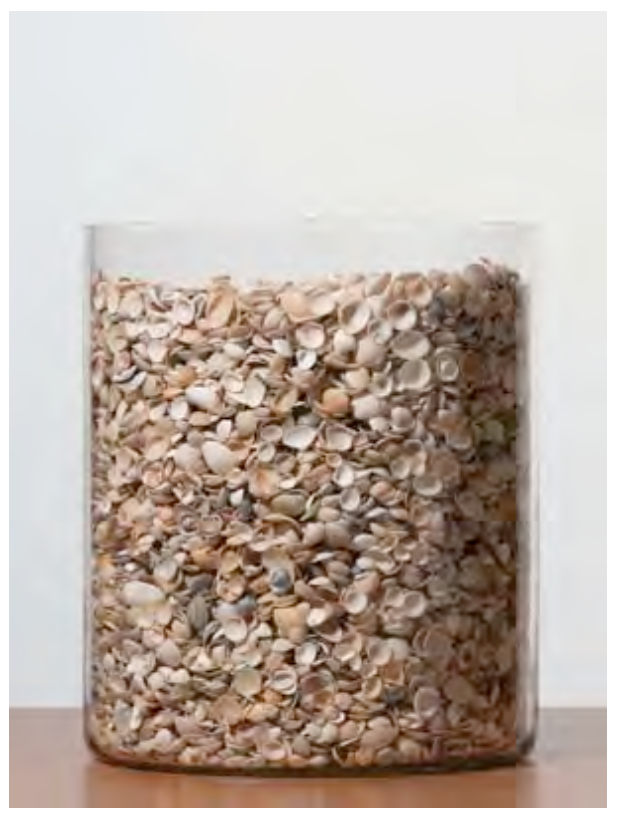

Bólide 
De acordo com o filósofo Celso Favaretto (1992), é possível identificar duas fases na obra de Oiticica: uma mais visual, que tem início em 1954 na arte concreta e vai até a formulação dos Bólides, em 1963, e outra sensorial, que segue até 1980.

Dando continuidade à criação dos Bólides, Oiticica concebe, em 1964, o primeiro Parangolé, que viria a ser a primeira capa como proposição da experiência da cor no corpo. $\mathrm{O}$ Parangolé é uma espécie de capa colorida que deve ser vestida pelo participante. Vestir o Parangolé e dançar constituem princípios desta proposição que prevê a experiência do corpo em movimento. $\mathrm{O}$ ato corporal como ação formadora e transformadora da percepção. Os Parangolés são como pinturas ou esculturas vivas e ambulantes.

Bólides e Parangolés são proposições ou estruturas perceptivas que propõem interferências no campo da sensibilidade. Pode-se dizer que mais do que criar novos objetos, ele coloca em prática um projeto estético ampliado.

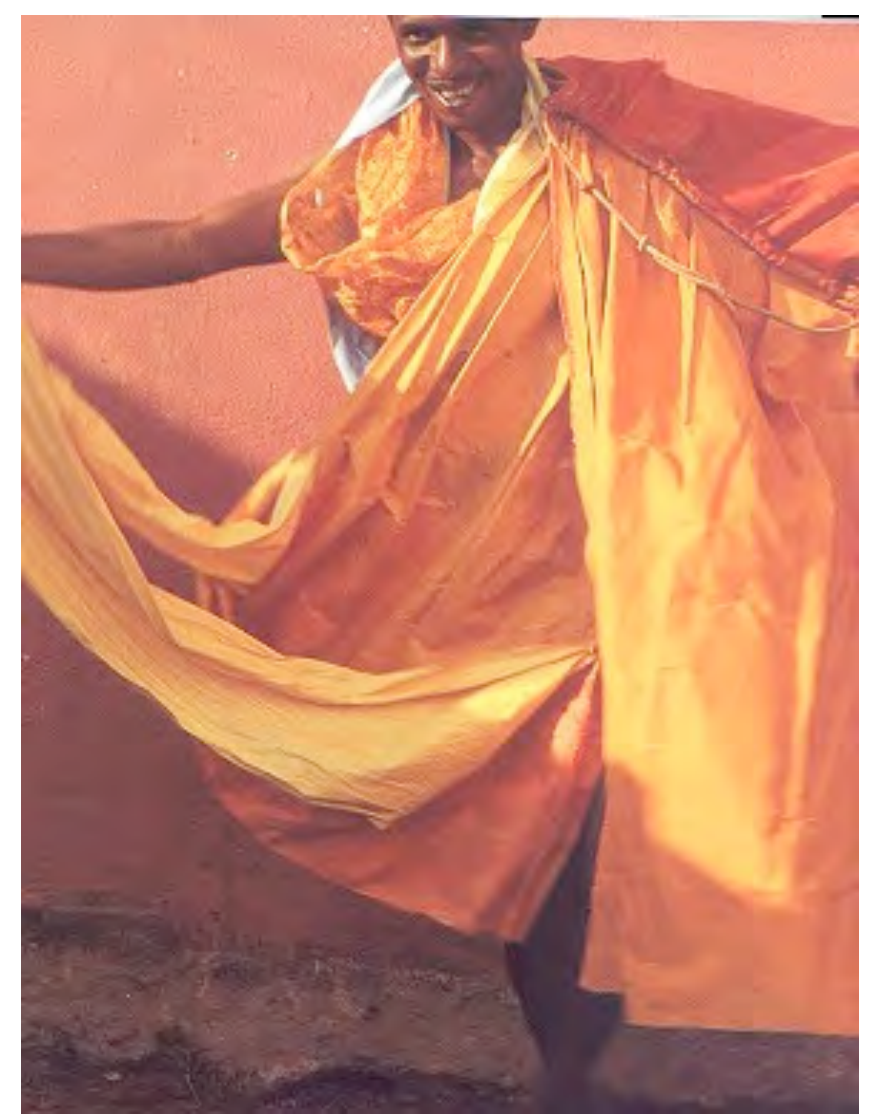

Parangolé

Para Helio Oiticica, a chave daquilo que ele chama de "arte ambiental" está no eternamente móvel, no ato do espectador e naquilo que é transformável, naquilo que acompanha o ato perceptivo. 
Em 1967, o destaque da sua produção é o trabalho Tropicália, considerado o apogeu de seu programa ambiental e apresentado na exposição Nova Objetividade Brasileira, no MAM/RJ. Tropicália é um labirinto penetrável que estimula o espectador a partir de interações físicas, como pisar na areia.

Oiticica transita da teoria do Não Objeto, de Ferreira Gullar, que questiona a dissolução do objeto de arte para a criação em um espaço coletivo que integra e solicita a participação. O artista radicaliza e pensa a "obra" como o "mundo".

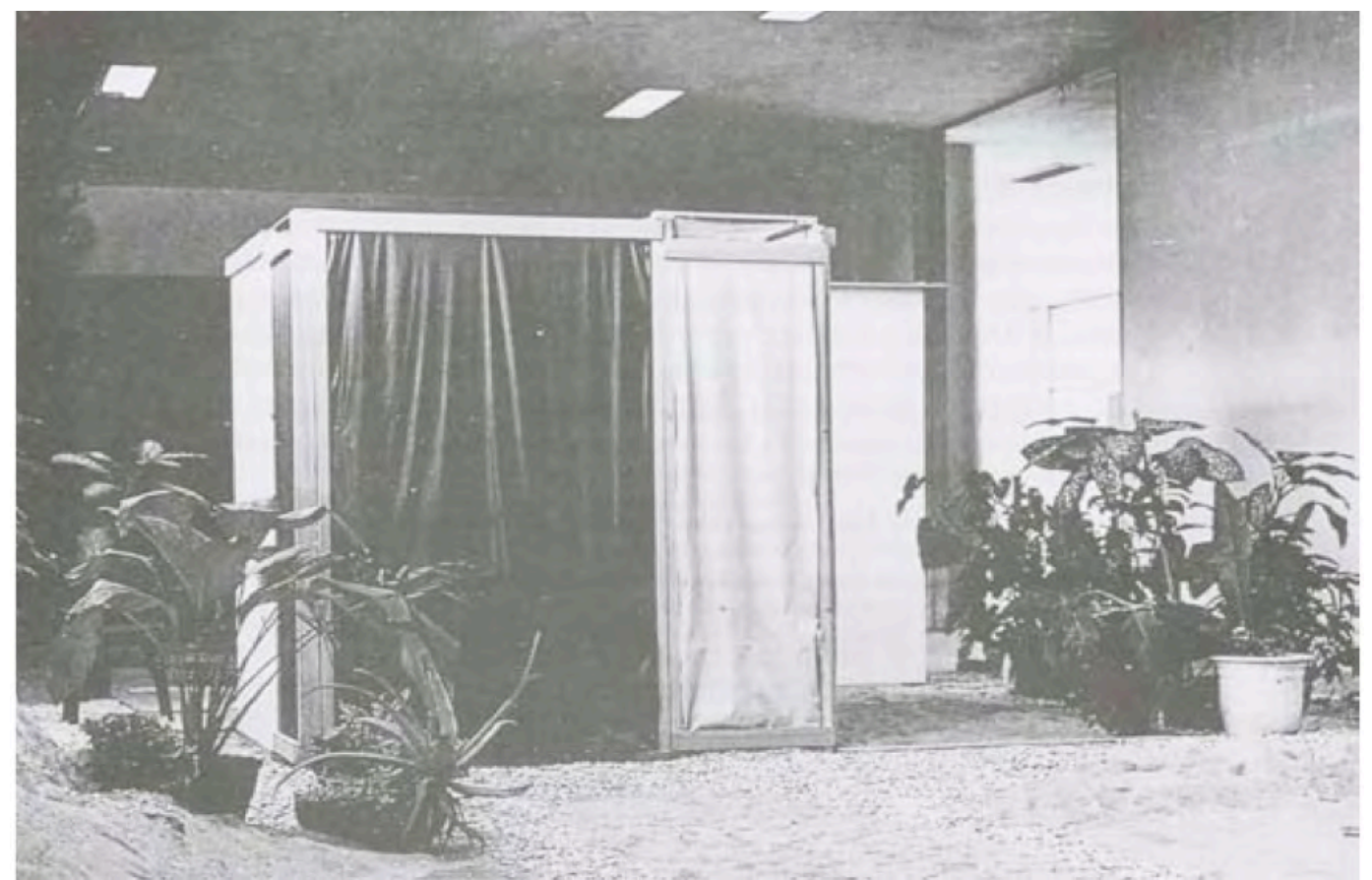

Tropicália, Oiticica

\section{Lygia Clark}

Lygia Clark se interessa pela arquitetura e pelos encontros possíveis entre o quadro e o ambiente. A pintura que antes repousava sobre o quadro, se movimenta percorrendo novos caminhos. Surge um lugar de tensão entre o quadro e o mundo.

Clark "desdobra gradualmente o plano em articulações tridimensionais - "casulos", "bichos" e "trepantes" - onde vai se insinuando a participação do espectador." (Milliet, 1992:21). Sua trajetória coincide com rupturas e investigações que promovem a superação da obra unidade separada do entorno.

O plano, assim como o quadro como espaço semântico isolado é superado e aos poucos é inserido à sala onde é exposto. Há uma continuidade, uma transferência do olhar da figura 
para as linhas que percorrem um espaço que convencionalmente é destinado ao espectador. Abalos na imagem reverberam criando movimentos que já não cabem mais no espaço fechado da moldura.

\footnotetext{
O plano é um conceito criado pelo homem com fins práticos: para satisfazer sua necessidade de equilíbrio. O quadrado, criação abstrata, é um produto do plano. $\mathrm{O}$ plano, marcando arbitrariamente os limites do espaço, dá uma ideia inteiramente falsa e racional de sua própria realidade. Daí surgem os conceitos antagônicos como $\mathrm{o}$ alto e o baixo, o avesso e o direito - contribuindo para destruir no homem o sentimento da totalidade. É também a razão pela qual o homem projetou sua parte transcendente e lhe deu o nome de Deus. Assim colocou o problema de sua existência - inventando o espelho de sua própria espiritualidade.

O quadrado se carregava de uma significação mágica quando o artista o considerava como levando uma visão total do universo. Mas o plano está morto. (CLARK, 1980:13)
}

Enquanto o quadro deixa de ser suporte e área de representação isolada do entorno, o movimento, a ação e a interação passam a mobilizar o fenômeno da arte. A relação do artista com a sua produção e o vínculo do espectador com o acontecimento artístico ganham sentido à medida que o quadro, como lugar fechado de representação, perde sentido.

Das incursões dos trabalhos de Clark pelo espaço antes destinado ao público, nascem as proposições que incentivam a participação e que serão responsáveis pela grande notoriedade da artista. É quando as linhas fogem para o espaço que novas experiências são investigadas e inaugura-se uma fase na qual a ação do espectador será determinante para o acontecimento artístico.

Entre as proposições que solicitam a presença de espectador e conseqüentemente de seu corpo como elemento fundamental da experiência artística, é possível trazer dois exemplos.

O primeiro exemplo é da fase Nostalgia do Corpo, de 1966. Clark pretende despertar a consciência do corpo a partir da redescoberta dos sentidos. Nostalgia indica saudade e um possível resgate do corpo perdido. O reencontro com este corpo esquecido acontece por meio de objetos que agem como intermediários dentro do processo de despertar as sensações corporais. Os objetos utilizados são elementos do cotidiano, como água, sementes, conchas e borrachas, por exemplo.

Nesta fase em que as propostas consistem na manipulação de objetos que poderão sensibilizar o corpo, Clark propõe ainda luvas, óculos e cintos, e sugere ambientes e roupas que tendem a estimular a percepção. Como exemplo, tem-se Luvas Sensoriais, que coincide com a redescoberta do tato. Nestes trabalhos, as experiências são vividas individualmente. $\mathrm{O}$ participante está ainda sozinho. Ele manipula objetos e atualiza memórias esquecidas. A ativação de sensações, memórias e impressões são as bases por onde transitam as proposições 
de Lygia Clark nesta fase. As proposições seguintes se destinarão a duplas e por fim a grupos.

Em 1968 a artista cria a instalação Casa é Corpo, que simula o aparelho reprodutor feminino e permite a passagem de pessoas em seu interior.

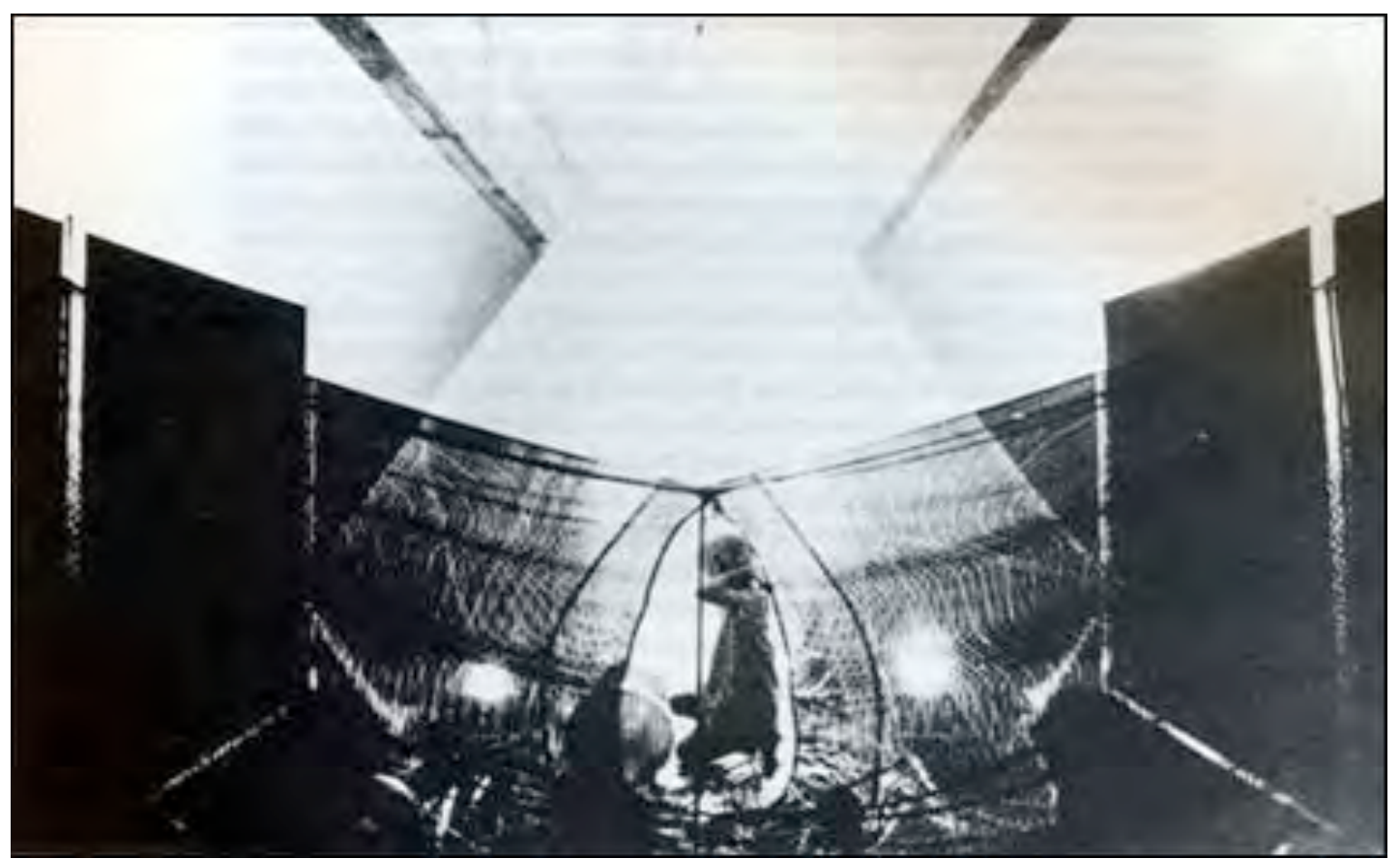

Lygia Clark. "Casa é o Corpo: Labirinto”, 1968. Instalação realizada no MAM-RJ e na Bienal de Veneza, em 1968.

A partir de 1969 destacam-se as experiências em grupo, e ainda de acordo com Milliet: "Esse corpo revisitado adquire dimensão social e, entrelaçado a outros, forma uma trama de comunicação coletiva." (Milliet, 1992: 30). As práticas deste período são conhecidas como Corpo Coletivo.

Um dos trabalhos desta fase, Mandala (1969), tem como proposta a aproximação, a relação e a ligação entre indivíduos. Elásticos ligam os participantes pelos pulsos e tornozelos. Há aqui um modelo existencial que coincide com a superação das dicotomias, quando a ação de um repercute no todo. A ação de um participante interfere na ação dos demais. 

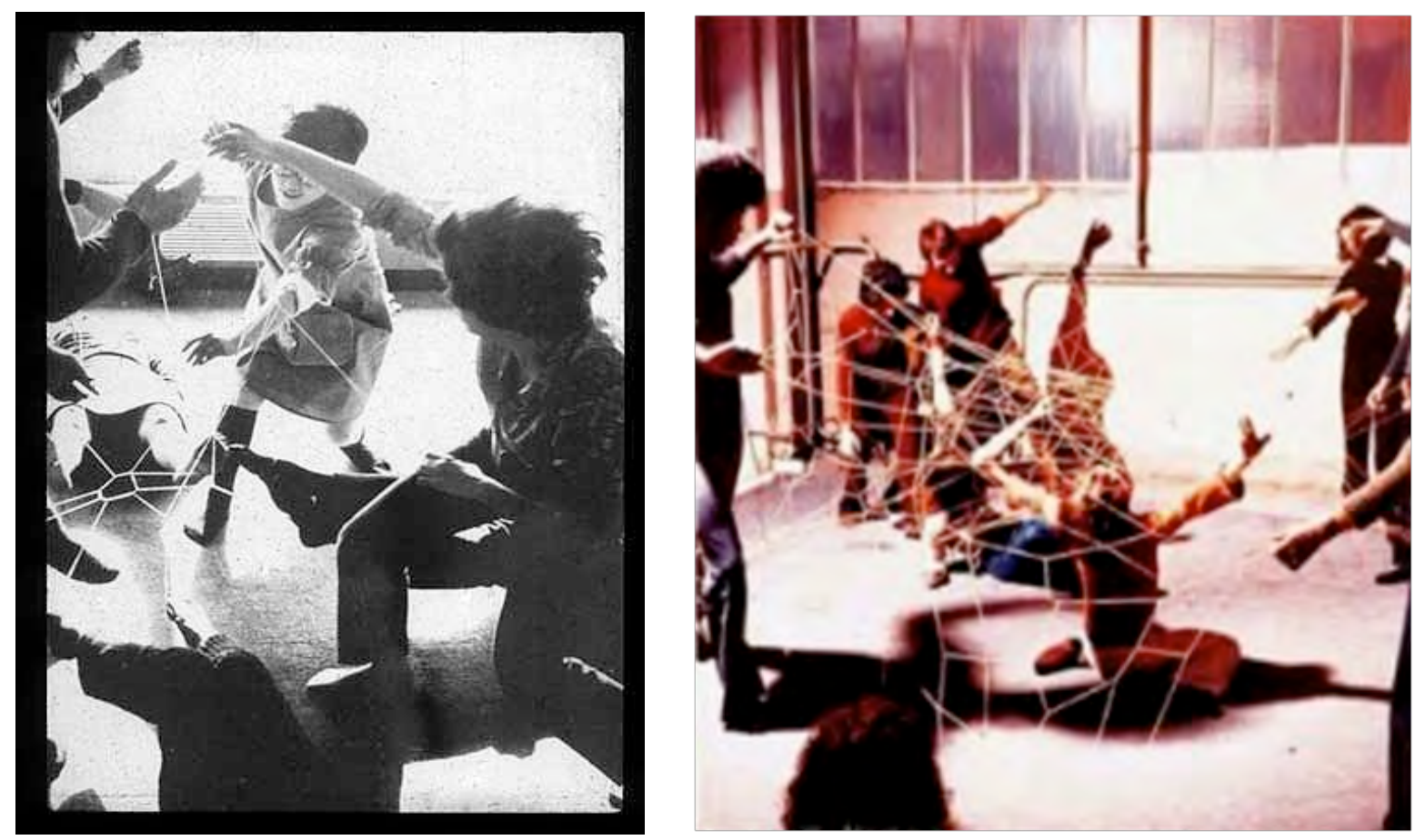

Mandala, 1969

Por fim, é possível dizer que as produções de Helio Oiticica e Lygia Clark, inseridas nos movimentos de vanguarda do século XX, especialmente entre os anos 50 e 70, provocaram expansões de limites do campo artístico e questionamentos sobre a função e o espaço da arte. O espaço de representação é, aos poucos, transformado em tempo-espaço "vivo" e o fenômeno da arte passa a se constituir na relação com o espectador.

A partir das propostas de Oiticica e Clark, mencionadas acima, é possível relacionar ou perceber a presença de princípios de seus trabalhos presentes nas estruturas de diversas propostas da cena contemporânea. A construção de ambientes, a expansão e crise do lugar de representação e a ativação da percepção do espectador, no contexto do fenômeno da arte, aparecem como características, pistas e traços de uma produção que se dá como um possível ambiente de interação. Lugares que pressupõem a habitação, espaço por onde transitam desejos, afetos e forças que transformam o lugar. $\mathrm{O}$ espaço se move, se molda e arquiteturas teatrais são criadas.

Os questionamentos referentes aos limites da pintura, a superação da tela como espaço ilusório e de representação e os avanços desta mesma pintura pelo espaço das galerias, dos museus e para fora deles, permitiram a reformulação de concepções institucionais e a expansão das experimentações artísticas. E nas palavras de Ferreira Gullar, 
superfícies mais contraditórias, fugir pela janela para além dos edifícios e das montanhas e ocupar o mundo. É a redescoberta do espaço. (GULLAR, 1980:9)

A redescoberta do espaço e a experimentação foram os principais focos de interesse do Neoconcretismo. O Movimento Neoconcreto, de 1959, formado por artistas como Lygia Clark, Helio Oiticica, escritores e poetas incentivou grandes mudanças nas abordagens e perspectivas artísticas. E de acordo com o "Manifesto Neoconcreto":

\begin{abstract}
Não concebemos a obra de arte nem como "máquina", nem como "objeto", mas como um quasi-corpus, isto é, um ser cuja realidade não se esgota nas relações exteriores de seus elementos; um ser que, decomponível em partes pela análise, só se dá planamente à abordagem direta, fenomenológica. Acreditamos que a obra de arte supera o mecanismo material sobre o qual repousa, não por alguma virtude extraterrena: supera-o por transcender essas relações mecânicas (que a Gestalt objetiva) e por criar para si uma significação tácita (M.Ponty) que emerge nela pela primeira vez. ( Manifesto Neoconcreto, 1959) ${ }^{161}$
\end{abstract}

Helio Oiticica, determinado a investigar a dissolução da área retangular do quadro e inaugurar um novo espaço para a pintura, constrói os não-mais-quadros, que de acordo com Vera Martins ${ }^{162}$, “ora são pendurados no teto isoladamente, ora em grupos, formando uma trama suspensa" (2009:20)

De acordo com Oiticica:

\begin{abstract}
Sinto que a o quadro não satisfaz de forma alguma as necessidades de expressão do nosso tempo. A eliminação do quadro é continuação, de certo modo, da eliminação da figura. Isto porque o quadro é um espaço a priori - um retângulo, um suporte para a contemplação. É um elemento contemplativo por excelência. Quando existe um suporte, para que se faça em seu interior uma composição, o que decorre é sempre uma figuração. Dado o quadro, temos o suporte para a figuração. (OITICICA por MARTINS, 2009:21)
\end{abstract}

Oiticica (2009) pontua ainda que vários pintores colocam em questão, de diferentes maneiras, a necessidade de destruição do quadro que, de acordo com o artista, é uma necessidade em sua época sentida universalmente. A desmontagem da área retangular e previsível do quadro permite a abertura da pintura para novas experiências.

Do mesmo modo, a superação do balé como estruturação geométrica pautada em regras

\footnotetext{
${ }^{161}$ Publicado no Suplemento Dominical do Jornal do Brasil em 21 e 22 de março de 1959. Texto disponível no livro Neococretismo, de Ronando Brito, 1999:10.

${ }^{162}$ Texto: A transformação dialética da pintura, por Vera Martins, no livro Encontro, Hélio Oiticica, publicado em 2009, e publicado originalmente no Suplemento Dominical do Jornal do Brasil, em 21 de maio de 1961.
} 
e relações fixas com a superfície e com o espectador são também criticadas por Forsythe. As estruturas regulares e sem relações diretas com o entorno divergem dos pensamentos e das abordagens contemporâneas.

Como exemplo dessa crise do plano, Oiticica cita Jackson Pollock (1912-1956). A grande dimensão da tela que Pollock esticava no chão era um fator determinante na construção de novas dinâmicas e perspectivas para a produção da pintura. $\mathrm{O}$ retângulo ou quadro, passa a agir sob o corpo do pintor de tal modo que a pintura surge agora de uma intensa interação física do artista com uma espacialidade, que mesmo ainda centrada no espaço da tela, reverbera agora em todas as direções. $\mathrm{O}$ quadro surge muito mais como plataforma de diálogo do artista com a sua matéria do seu trabalho do que como espaço vazio e passivo para o gesto.

A área do quadro se desdobra, as poucos, em ações que desvinculam a noção de quadro do conceito de pintura. E é justamente nesse movimento de deslocamento que localizo a curiosidade investigativa de Forsythe de pensar o dança desvinculada das noções clássicas de coreografia.

Com os Objetos Coreográficos, o intuito é investigar as possibilidades da dança sem a presença das estruturas já conhecidas, como a composição de desenhos coreográficos fechados e a presença de bailarinos. Como pensar a dança para além desse esquema? Como pensar a pintura para além da noção de quadro?

Pintura não é sinônimo de quadro, assim como coreografia não é sinônimo de dança.

Hélio Oiticica, William Forsythe, Lygia Clark entre outros, aparecem aqui coreógrafos no sentido amplo do termo. Todos se preocuparam e atuaram nos limites entre corpo e espaço propondo novas dinâmicas de interação, deslocamento e investigação no qual sujeito e objeto se transformam em agentes de um processo contínuo de descobertas e revelações de novos referentes.

Objeto e sujeito como coisa, plasmação e não um a serviço do outro. A função utilitária dá lugar a um espaço amplo e sem bordas que é constituído em trânsito e que encontra algum repouso na composição de novos lugares, estruturas, paisagens, alturas, intensidades, silêncios, palavras, idiomas, temperaturas e texturas.

\section{Fragilidades}

De acordo com as considerações acima, localizo as propostas de Forsythe nesse intervalo crítico e dinâmico no qual a construção e a justaposição de lugares estimulam 
diálogos entre as suas práticas e as problemáticas investigadas pelos artistas aqui mencionados. Na ativação de elementos e na construção de situações e relações surgem formações frágeis e temporárias que dialogam com o teatro contemporâneo. A fragilidade das formas trata de um projeto experimental que lançará mão dos mais variados estímulos e elementos para a composição de espacialidades e paisagens desconhecidas.

A condição abordada neste estudo coincide com deslocamentos e o acionamento de dinâmicas que vinculam o corpo e incitam o surgimento de ambientes precários e fugidios.

Problemáticas das artes visuais, da arquitetura, de noções sobre instalação, da dança e da filosofia formam um escopo que orienta e estimula a observação de elementos estruturais, texturas, materiais e princípios que expandem articulações entre corpo, espaço, voz, palavras e demais estímulos que agem e interferem na produção artística.

O neoconcretismo brasileiro e mais precisamente o projeto ambiental de Oiticica apresenta indícios que verifico também nos Objetos Coreográficos de Forsythe. Não por serem essas manifestações análogas, mas por convidarem o corpo a percursos, danças e caminhadas por paisagens frágeis, lugares que promovem giros e flutuações. O modo como vejo e as alterações da percepção dizem respeito a inauguração de espaços instalativos nos quais um olhar antropofágico vivencia saltos, presencia abismos e se move lentamente entre novas planícies e formações temporárias.

O imprevisível e o acaso aparecem como estímulos e ingredientes que alterarão a experiência do lugar, assim como prevê William Forsythe nos trabalhos Objetos Coreográficos. Tratarei pontualmente deste tema na sessão seguinte Suspensões, na qual apontarei desdobramentos de noções como objeto e coreografia no contexto dessas propostas.

\section{Advertência ¿}

Feitas as considerações e os apontamentos sobre ativações que solicitam a participação direta e física do espectador, vale o alerta:

Participar de uma instalação não é sinônimo de atividade, assim como assistir a um espetáculo em uma cadeira distante da cena tão pouco é sinal de passividade. O que entra em jogo nas articulações que indicam ação parece ser o surgimento de metáforas ou relações vivas e dinâmicas que estremecem convicções e categorias. O passivo, o receptor seria aquele que vê o que já conhece, que reconhece regras naquilo que vê ou experimenta. E nesse caso, tanto a arte renascentista quando a arte contemporânea são testemunhas de propostas que 
incitam a atividade ou a passividade. Quem não assistiu a um trabalho de arte contemporâneo e não viu lá uma repetição de princípios e procedimentos? Quem não se assustou diante de uma pintura tradicional limitada por uma grande moldura? Quando os olhos saltam, o corpo vibra, estremece e novos olhares para o mundo são criados. 


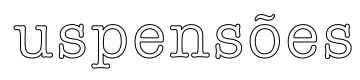


Escolho abordar a palavra Suspensão a partir de duas possíveis orientações que acentuam seu caráter instável e que se relacionam com os Objetos Coreográficos selecionados para essa seção. A primeira orientação sugere à palavra a condição de indeterminação, de suspense, daquilo que está por se fazer ou se manifestar. Essa orientação deixa em aberto conceitos, noções e considera o surgimento do inesperado. A segunda orientação diz respeito à ação física de suspender, de negociar com a gravidade, de alterar os eixos de apoio, de modificar a perspectiva espacial do corpo, dos ossos, de fazer girar articulações e de exigir esforços em novas direções.

Ambas orientações são provocações que fazem oscilar determinações espaciais, temporais e conceituais. Neste contexto, uma fenda se abre para que objeto e coreografia se apresentem como intervalos, como linhas em formação que ora se impõem e ora desaparecem.

Suspender conceitos ou definições que limitam a observação de fenômenos foi uma das principais problemáticas abordadas pela filosofia no contexto da "Suspensão do Juízo", que mais tarde será um dos pontos de apoio das colocações e discussões da Fenomenologia. Associado à suspensão radical do juízo está o ceticismo antigo, que nasce com Pirros de Élis. E entre os modos de argumentação encontrados pelos céticos, um deles está na variação constante de condições e pontos de vista que alteram radicalmente o modo como vemos e nos relacionamos com o mundo.

\begin{abstract}
Os órgãos dos sentidos variam de uma espécie para outra. A representação de um mesmo objeto deve, portanto, variar de uma espécie para outra em virtude dessas diferenças. Não temos, contudo, um critério para declarar que as percepções de uns representam mais fielmente a realidade que as percepções dos outros. O segundo, terceiro e quarto modos exploram o fato de que, segundo as circunstâncias juventude ou velhice, saúde ou doença, movimento ou repouso - um mesmo sujeito não vê necessariamente o mesmo objeto sempre da mesma maneira. Além disso, as sensações que um sujeito tem variam também segundo o lugar, a posição e a distância do objeto. Outro argumento lembra que os costumes, as leis, as crenças variam. Todos os dez modos apelam para vários fatores (tais como as condições que afetam o sujeito e o objeto e as circunstâncias em que o objeto se encontra), que influenciam a maneira como as coisas nos aparecem. A conclusão é que o conhecimento sensível é relativo; que podemos dizer como as coisas nos aparecem, mas não como são em si mesmas, em sua natureza real; e que sobre este último ponto devemos suspender o juízo. (CONTE, 2010)
\end{abstract}

A suspensão das ideias que imediatamente associamos às noções de Objeto e de Coreografia é um dos principais desafios quando nos aproximamos de alguns entre tantos

\footnotetext{
${ }^{163}$ No texto "O início: Sexto Empírico e o ceticismo pirrônico", de Jaimir Conte. Disponível no link: http://revistacult.uol.com.br/home/2010/03/o-inicio-sexto-empirico-e-o-ceticismo-pirronico/. Acesso em julho de 2015.
} 
trabalhos da série Objetos Coreográficos. Coreografia e objeto aparecem aqui sob uma perspectiva fenomenológica e multifocal que convida o corpo e os sentidos a percorrem órbitas imprevisíveis. Os conceitos de objeto e coreografia se aderem às interferências ambientais e à decorrência de situações e particularidades que desafiarão a percepção. Particularidades da matéria, dos materiais que entram em relação com o corpo, e particularidades do corpo na relação com o entorno irão compor paisagens de diferentes matizes. Pensamentos são gerados nesses ambientes aguados que borram limites entre objeto, forma, matéria e tempo.

Pode-se dizer que a produção de Forsythe é influenciada pela abertura de conceitos e relações propostas por artistas como Marcel Duchamp e se aproxima também de abordagens do Minimalismo no que diz respeito ao reposicionamento da percepção e aos procedimentos que evidenciam a presença de linhas, formas e particularidades da matéria.

Durante a exposição The Fact of Matter ${ }^{164}$ William Forsythe destaca a importância e a influência de Richard Serra, figura importante no contexto do Minimalismo, em sua trajetória e exemplifica uma das grandes contribuições do artista com a seguinte frase de Serra ${ }^{165}$ : "Eu sempre parto do princípio de que meu público é muito mais inteligente do que eu". O destaque à presença viva, física, vigorosa e pensante do espectador é uma das principais contribuições das vanguardas na abertura de possibilidades múltiplas para o fenômeno da arte.

Forsythe cita ainda o trabalho de Duchamp 3 stoppages étalon (3 Standard Stoppages), de 1913-4, e afirma que o artista foi um dos maiores coreógrafos do século $\mathrm{XX}^{166}$. O humor e a ironia de Duchamp frente a parâmetros e medidas encontram ressonâncias nas abordagens de Forsythe e aparecem em propostas do artista que desafiam ordens e parâmetros instituídos. A noção coreográfica que aparece nos trabalhos de Forsythe desafia modelos previsíveis e supera relações específicas e pautadas em modelos de representação criados para forjarem

\footnotetext{
${ }^{164}$ A abertura da exposição aconteceu no dia 16 de Outubro de 2015. A exposição The Fact of Matter, que aconteceu no Museu de Arte Moderna (Museum für Moderne Kunst - MMK) de Frankfurt, de 17 de outubro de 2015 a janeiro de 2016, traz uma retrospectiva dos Objetos Coreográficos de William Forsythe no ano de sua despedida da Alemanha. O projeto curatorial previa uma aproximação entre os trabalhos de Forsythe, pautados na expansão do conceito de coreografia, com obras da coleção do MMK. Entre os artistas que compõem a coleção do museu estão: Marcel Duchamp, Bruce Nauman, Richard Serra, entre outros. Um panorama minimalista e de vanguarda é confrontado com os trabalhos atuais e antigos de Forsythe. Essa exposição seria como um novo começo de Forsythe em Frankfurt. Link: https://www.youtube.com/watch?v=OAyNzdaKjIk. Acesso em 20 de outubro de 2015.

${ }^{165}$ Depoimento de Forsythe no vídeo da exposição The Fact of Matter.

Link: https://www.youtube.com/watch?v=OAyNzdaKjIk. Acesso em outubro de 2015. Fala: "I always assume that my audience is much more intelligent than I am".

${ }^{166}$ Comentário disponível no vídeo institucional da exposição The Fact of Matter que aconteceu no Museu de Arte Moderna de Frankfurt am Main (MMK), de outubro de 2015 a janeiro de 2016, https://www.youtube.com/watch?v=OAyNzdaKjIk._Acesso em dezembro de 2015.
} 
vínculos viciados e repetitivos entre matéria e espaço.

Os questionamentos e os experimentos sugeridos pelas vanguardas, sobretudo pelo minimalismo, evidenciam a presença da matéria, das massas e formas que produzem espacialidades e possibilidades de aproximação e experiência do evento artístico.

A partir dessas duas considerações de Forsythe que tocam em pressupostos e questionamentos colocados por Duchamp e por iniciativas minimalistas, proponho um olhar sobre aberturas e expansões produzidas por ações de vanguarda que favoreceram o deslocamento e a variação de referenciais, de pontos de observação e da prática em arte em diferentes contextos e experiências.

Antes de abordar particularidades da série Objetos Coreográficos e apresentar alguns dos trabalhos que selecionei para essa seção, sinalizarei fundamentos encontrados em procedimentos das vanguardas artísticas do início e meados do século XX que reverberam na produção de Forsythe.

No século XX, e sobretudo, as décadas de 50 e 60 foram fundamentais para a desestabilização de padrões e modelos que regulavam práticas e teorias sobre arte.

Objeto, espaço e sujeito passam a compor uma paisagem na qual as suas constituições acontecem no diálogo entre suas forças e potências. A expansão de conceitos reformula importantes concepções. Na arte, o lugar da representação, como a manifestação do mimético, é colocado em questão enquanto um lugar de relações e partilhas é inaugurado. Uma sequência de transformações é acompanhada por uma série de múltiplos experimentos no campo das artes.

A pintura atravessa o quadro, a dança investiga a superação de padrões de movimento, a música silencia, pausa, o teatro desmonta os limites do palco e é nesse ambiente efervescente de rearticulações que os movimentos artísticos experimentarão a liberdade de composições aleatórias que fundamentam as práticas contemporâneas.

Os padrões de representação dão lugar a um campo processual e efêmero no qual propriedades da matéria, do tempo e do espaço passam e ser provadas pelos sentidos e pelo corpo.

$\mathrm{O}$ interesse pela materialidade, por um retorno às propriedades inerentes à matéria, e pelas relações entre corpo e espaço, marcaram a atuação de artistas como Richard Serra e de tendências minimalistas que se fundamentaram no exercício da percepção. Um retorno às qualidades físicas e materiais estimulam novas condições para as relações entre público e obra. Os sentidos passam a ser construídos no instante em que obra e espectador se tocam. Pode-se dizer que o lugar da representação se desestabiliza e que já não há, nesse contexto, 
um discurso prévio e preparado como um simulacro que se apresentará ao espectador.

As múltiplas manifestações das práticas contemporâneas confirmam a investigação do espaço sob uma perspectiva na qual seu conceito coincide com um trama de ações, movimentos, declives e curvas que orientam diferentes experiências artísticas e espaciais. Público e obra tendem a ser misturar em um conjunto sonoro, visual e sensorial no qual os sentidos se constituem em movimento.

Um campo de instabilidades, flutuações e construções que não se limitam a verdades e imitações da realidade imediata é inaugurado pelos movimentos de vanguarda.

Aquilo que se pautava em normatizações estáveis ganha agora contornos mais fluídos, frágeis e móveis. O objeto como lugar fechado e separado do entorno se deforma ao considerar fissuras, rasgos e aberturas como interstícios de conexão com o entorno.

\section{Duchamp}

O desvinculamento de Marcel Duchamp de uma perspectiva unilateral fez com que sua atuação fosse marcada pelo trânsito entre linguagens e pela sugestão de lugares não reconhecíveis. Duchamp atuou como pintor, curador, escultor, criou e participou de filmes, produziu miniaturas de seus trabalhos, que são encontradas nas famosas malas verdes, se apropriou e transformou imagens consagradas, como a Monalisa, de Leonardo Da Vinci, adicionou humor aos trabalhos, assinou seus trabalhos com pseudônimos, como R. Mutti, e foi responsável pela curadoria de exposições Surrealistas nas quais o público deparava-se com situações inusitadas para o contexto expositivo do início do século XX. Duchamp posou ainda para fotos de Man Ray, seu amigo, travestido de Madame Rrose Sélavy, e com esse mesmo nome assinou muitos de seus trabalhos. Rompeu com as estruturas narrativas tradicionais do cinema ao criar, em 1926, com a colaboração de Man Ray, o filme experimental Anémic Cinema, composto por discos giratórios com imagens de círculos em espiral e fragmentos textuais, presentes em alguns dos discos, que entram em movimento e provocam a imaginação e a percepção do espectador.

Este breve panorama de algumas das propostas de Marcel Duchamp confirma sua atuação como propositor que dialoga e provoca o espectador em diferentes situações. Se conceitualmente ou sensorialmente, o intuito de Duchamp parece ser um só: desestabilizar as relações institucionalizadas entre obra e espectador para que o pensamento se descubra como o acidental, o imprevisível e como tudo que está ainda por ser criado ou vivenciado. 
O trabalho 3 stoppages étalon (3 Standard Stoppages), ou três interrupções/suspensões de padrão, de 1913-4, consiste em um experimento feito por Marcel Duchamp no qual medidas e padrões lógicos são questionados. Duchamp solta três fios, de um metro cada, em réguas de madeira. Os fios caem de uma altura de um metro, igual a de suas medidas, tocam a superfície e se transformam em impressões sobre madeira. Duchamp joga com a padronização das medidas que regulam experiências espaciais e temporais. A ironia de Duchamp e suas provocações agem na produção de alternativas que contestam regimes e sistemas estáveis. E é neste ponto que Duchamp é considerado, por William Forsythe, como o maior coreógrafo do século $\mathrm{XX}^{167}$.

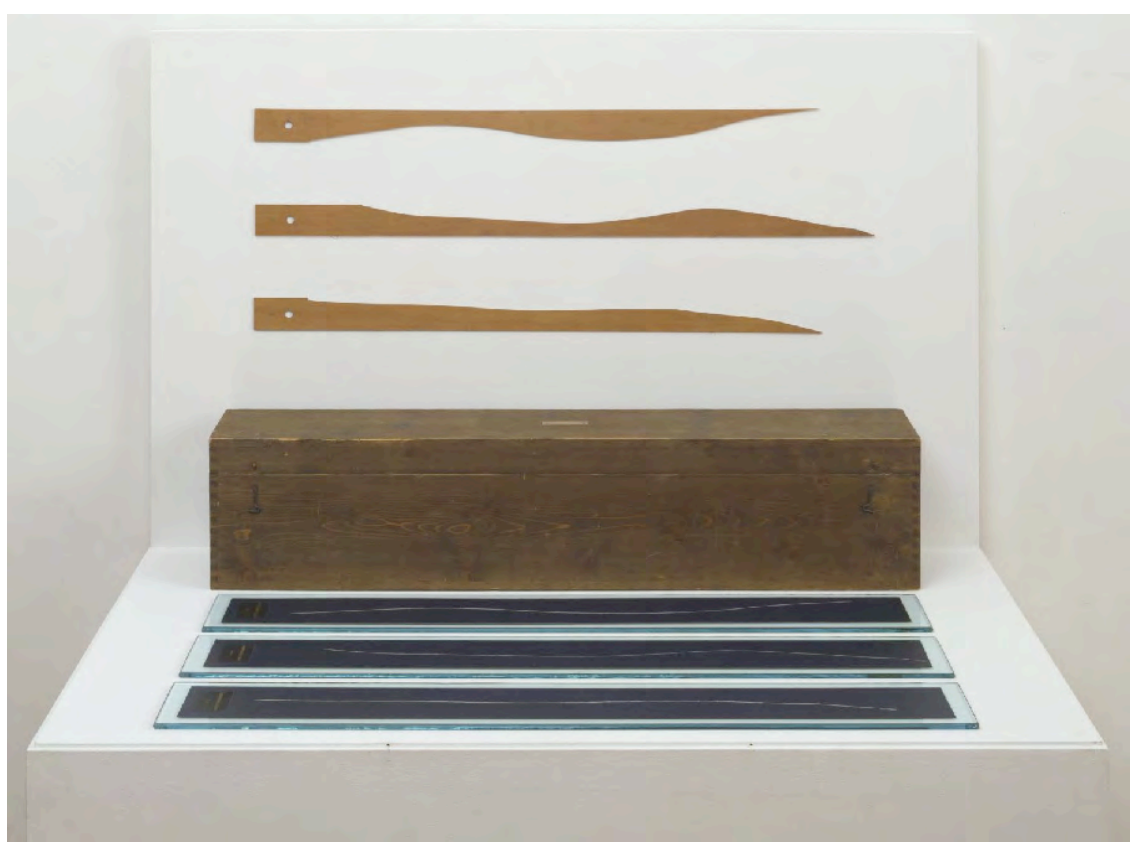

3 stoppages étalon (3 Standard Stoppages)

A abertura para novas possibilidades no processo de apreender e gerar situações, leituras e contatos com o mundo foi o empurrão inicial em uma série de transformações práticas e teóricas que ainda hoje especulam as dinâmicas que tencionam e produzem arte. Essas dinâmicas podem ser analisadas, no contexto dos Objetos Coreográficos, a partir da rearticulação de noções que dão nome a série: os conceitos de objeto e coreografia.

Para abordar a série da trabalho intitulada Objetos Coreográficos considero importante partir de noções que estão presentes na própria nomenclatura desses trabalhos. O nome da série "Objetos Coreográficos" carrega e sinaliza importantes definições que auxiliam no

\footnotetext{
${ }^{167}$ William Forsythe fez essa afirmação em uma conversa pública que aconteceu no Museu de Arte Moderna de Frankfurt (MMK) no dia 18 de novembro de 2015 e na qual estive presente.
} 
mapeamento e na investigação de problemáticas propostas por esses trabalhos.

Os termos objeto e coreografia são noções ou conceitos que fundamentam e problematizam princípios presentes nos Objetos Coreográficos de William Forsythe.

Apresento um breve panorama na qual estão implícitas considerações sobre a noção de objeto, bem como reflexões sobre condições espaciais e perceptivas que flexibilizarão e expandirão o conceito de coreografia.

Reviravoltas na noção de objeto fomentam importantes discussões sobre as relações entre obra e espectador ao mesmo tempo em que solavancos no modo de perceber criaram novos parâmetros para o pensamento e prática em arte. Mudanças de perspectiva sob a noção de objeto prevêem interações entre forma, matéria e tempo. Coreografar, no sentido aqui empregado, diz respeito ao ato de compor e transitar por estruturas porosas e flexíveis que dinamizam relações entre corpo e espaço.

\title{
Objeto
}

A noção de objeto abordada por William Forsythe, na série Objetos Coreográficos, coincide com problemáticas e questões apresentadas pela Teoria do não-objeto ${ }^{168}$, de Ferreira Gullar. O texto, produzido no contexto do movimento Neoconcretista brasileiro, foi publicado no ano de 1959 e contribuiu com importantes reflexões acerca da produção de arte sob uma perspectiva mais processual e fenomenológica e é uma importante referência que pontua a abertura e superação do conceito de objeto como coisa objetiva e apreensível. O objeto aparece como ativador, mobilizador de dinâmicas e campos perceptivos que são experimentados física e sensorialmente. De acordo com Gullar:

\begin{abstract}
A expressão não-objeto não pretende designar um objeto negativo ou qualquer coisa que seja o oposto dos objetos materiais com propriedades exatamente contrárias desses objetos. O não-objeto não é um antiobjeto mas um objeto especial em que se pretende realizada a síntese de experiências sensoriais e mentais: um corpo transparente ao conhecimento fenomenológico, integralmente perceptível, que se dá à percepção sem deixar resto. (GULLAR, 2007:90) $)^{169}$
\end{abstract}

O conceito de objeto surge na dissolução de categorias, expande a compreensão de fenômenos e desmonta modelos pautados em categorias fixas. O objeto se move, é agente de

\footnotetext{
168 O texto "Teoria do Não-Objeto", de Ferreira Gullar, apareceu numa edição do Suplemento Dominical do Jornal do Brasil como contribuição à II Exposição Neoconcreta, realizada no salão de exposição do Palácio da Cultura, Estado da Guanabara, de 21 de novembro a 20 de dezembro de 1960.)

${ }^{169}$ Ferreira Gullar, Teoria do Não-Objeto, no livro "Experiência Neoconcreta: momento-limite da arte", 2007.
} 
uma série de relações que estabelece com o mundo.

\begin{abstract}
Romper a moldura e eliminar a base não são, de fato, questões de natureza meramente técnica ou física: trata-se de um esforço do artista para libertar-se do quadro convencional da cultura, para reencontrar aquele "deserto" de que nos fala Malevitch, onde a obra aparece pela primeira vez livre de qualquer significação que não seja a de seu próprio aparecimento. Pode dizer-se que toda obra de arte tende a ser um não-objeto e que esse nome só se aplica, com precisão, àquelas obras que se realizam fora dos limites convencionais da arte, que trazem essa necessidade de deslimite como a intenção fundamental de seu aparecimento. (GULLAR, 2007:94)
\end{abstract}

Os objetos no contexto da arte moderna e contemporânea percorrem um trajeto de emancipação em relação ao lugar de isolamento que ocupavam e se libertam de seus limites, pedestais e molduras lançando-se a um espaço que era antes reservado ao espectador.

Concepções e premissas conduzem pensamentos e questões filosóficas que movem e fundamentam as transformações desse período. A ideia de absoluto, de moral, de uma verdade fechada e acabada em si dá espaço ao transitivo e ao efêmero. Os objetos passam a ser abordados como potências ou campos de força participantes no estabelecimento de relações, vínculos e transformações da percepção. De passivos, tornam-se agentes.

O Minimalismo é um dos movimentos que apresentará importantes contribuições para a observação do objeto sob uma perspectiva que enfatiza a materialidade e qualidades espaciais que se manifestam na presença da matéria no espaço. Volumes, estruturas vazadas e uma variedade de arranjos geométricos e espaciais confrontarão o espectador com proporções, dimensões, massas e propriedades que alterarão definitivamente relações amparadas por narrativas lógicas, lineares ou orientadas por estímulos que não são disparados por aspectos ou pela manifestação da matéria.

Relações entre o Neoconcretismo e o Minimalismo, com fundamentos da fenomenologia, são observadas no caráter processual dos eventos e na investigação de relações que levam em consideração o corpo e as dinâmicas da percepção nos fenômenos artísticos.

A autora Claire Bishop (2005) comenta a relação do Minimalismo com a fenomenologia de Maurice Merleau-Ponty: “A tradução para o inglês de seu livro A Fenomenologia da Percepção (1962) foi crucial para a teorização da escultura minimalista por artistas e críticos na década de 1960, e para a sua compreensão da intensa experiência corporal do espectador deste trabalho."(2005:10) ${ }^{170}$

\footnotetext{
${ }^{170}$ Texto original: "The english translation of his book The Phenomenology of Perception (1962) was crucial to the theorisation of Minimalist sculpture by artists and critics in the 1960s, and to their understanding of the viewer's heightened bodily experience of this work." (Bishop, 2005:10)
} 


\section{Minimalismo}

Algumas passagens do Minimalismo evidenciam a presença e a manifestação física da matéria no espaço. A afirmação de particularidades e qualidades da matéria interrompe o surgimento de modelos e tendências que apresentam a obra como metáfora, fábula ou enredo. O que vemos surgir a partir da materialidade que nos é revelada por investidas minimalistas, que criticarão perspectivas modernistas nas quais a obra aparecem como lugar ou objeto delimitado e independente da presença ou olhar do espectador, é o surgimento de linhas, cores, variações de peso, texturas, superfícies e volumes que provocarão novos modos de perceber e interagir com o meio.

O minimalismo, no entanto, se transforma. As tendências iniciais que se pautavam no isolamento da forma e na negação de narrativas, se transformarão posteriormente em abordagens a partir das quais a presença do espectador será fundamental no processo de construção de percepções em relação às formas propostas.

Se em um primeiro momento questões de ordem estrutural davam ênfase a aspectos da forma como modo de reduzir ao máximo vínculos entre forma e conteúdo ou de suprimir abordagens narrativas e dar destaque a literalidade daquilo que era visto, um momento posterior estará mais pautado na relação, nas possibilidades ambientais nas quais a presença da forma e do espectador serão fundamentais para o acontecimento da arte.

Outro aspecto importante é a noção de literalidade apresentada pelos minimalistas. O literal ou a literalidade acaba sendo alvo de críticas por tratar de uma relação direta com a forma, com aquilo que é dado sem que haja um apelo ao que a forma possa vir a representar. As críticas giram em torno da impossibilidade de uma relação que acontece a partir, exclusivamente, de aspectos formais que se colocam no espaço. As formas se interpõem de tal modo que movimentam a percepção do espectador em diferentes níveis, já que uma forma é muito mais do que uma junção ou um justaposição de arestas que se aproximam, se sobrepõem e se separam. As formas constituem imagens que percorrem sentidos e memórias que só serão revelados na relação e de forma particular e intransferível.

O autor Didi-Hubermann (2010), chama a atenção para essa contradição que aparece nos enunciados Minimalistas quando defendem a ideia de um anti-ilusionismo. Didi aborda essa premissa destacando aspectos da literalidade. O literal almejado pelos Minimalistas é uma condição que não corresponde ao modo como criamos vínculos ou como interagimos com formas e materialidades, já que, como coloca Hubermann, toda forma dialoga com memórias e sensações que são geradas nos encontros. Uma forma não é apenas uma forma. 
Aquilo que vemos é um cruzamento de imagens que habitam sonhos, registros físicos, devaneios e informações socialmente geradas.

Voltando aos enunciados minimalistas, ainda que o Minimalismo tenha surgido no contexto da pintura, é na escultura ou em propostas apresentadas por esculturas que aspectos e manifestações da matéria no espaço serão evidenciados. Materiais industriais, lâmpadas fluorescentes e aço são alguns dos materiais que serão utilizados na construção de relações e interações espaciais que apostarão na presença e experiência corporal do espectador.

Em exposicão pela primeira vez em 1959 com os "Black Paintings" de Frank Stella no Modern Art Museum de Nova Iorque, a atrair pela primeira vez a atenção da crítica em 1963 na Green Gallery com as obras de Robert Morris, e finalmente a confirmar-se como tendência em 1966 no Jewish Museum sob a designação de "Primary Structures", o minimalismo veio firmando terreno e facturando projeção e polêmica- a quantidade de rótulos para o movimento não é desigual à proliferacão das suas interpretacões: "arte das estruturas primárias", "cool art", "ABC art"17 , "literalist art", "topological art", só para referir alguns, vinham satisfazer a avidez de um vocabulário, de uma fórmula ou de um corolário que facilitasse a assimilacão de uma arte que resistia fortemente ao sentido, ao prazer visual e às convencões, procurando a pureza, o concreto, o imediato, o simples, o irrelacional e o objecto mais do que a obra. (FLORES, 2007) ${ }^{171}$

O minimalistas apresentam importantes considerações sobre a noção de objeto a partir de colocações que passam a analisar aspectos e condições espaciais e temporais nas quais ele está inserido. Essas condições se colocam como elementos decisivos que se revelam junto ao aparecimento dos objetos. Morris pontua:

A experiência do trabalho existe necessariamente no tempo. A intenção é diametralmente oposta ao cubismo com o seu interesse em vistas simultâneas em um único plano. Alguns dos trabalhos têm expandido os termos da escultura ao focar de modo mais enfático nas condições sob as quais certos tipos de objeto são vistos. $\mathrm{O}$ objeto em si é cuidadosamente colocado sob essas novas condições para fazer parte destes termos. $\mathrm{O}$ objeto sensual, resplandecente com relações internas compactadas, teve que ser rejeitado. Assim, muitas considerações devem ser levadas em conta a fim de que o trabalho mantenha o seu lugar como um termo de uma situação expandida, raramente indicando uma falta de interesse no próprio objeto. Mas os interesses agora são mais o controle e/ou a cooperação da situação como um todo. $\mathrm{O}$ controle é necessário se a variável de objeto (luz, espaço, corpo) tem uma função. $\mathrm{O}$ objeto em si não se tornou menos importante. Ele se tornou menos auto importante. (...). (MORRIS, “Notes on Sculpture 1-3”, 2002:819)

\footnotetext{
${ }^{171}$ Minimalismo e Pós-Minimalismo Forma, Anti-forma e Corpo na Obra de Robert Morris, Vitor Flores, 2007. http://www.livroslabcom.ubi.pt/pdfs/20110829-flores_victor_minimalismo_pos_minimalismo.pdf

${ }^{172}$ Texto original: "The experience of the work necessarily exist in time. The intention is diametrically opposed to Cubism with its concern for simultaneous views in one plane. Some of the new work has expanded the terms of sculpture by a more emphatic focusing on the very conditions under wich certain kinds of objects are seen. The object itself is carefully placed in these new conditions to be but one of the terms. The sensuous object, resplendent with compressed internal relations, has had to be rejected. That many considerations must be taken into account in order that the work keep its place as a term in the expanded situation hardly indicates a lack of interest in the object itself. But the concerns now are more control of and/or cooperation of the entire situation.
} 
E é sob essa perspectiva que deslocará o foco do objeto como manifestação fechada e com bordas definidas que a arte passará a se apresentar como força e experiência de troca e movimento no qual a circulação de energia gerará sempre novos pontos de vista e sensações. Morris comenta:

\begin{abstract}
O separação da energia da forma de arte do ofício da produção de um objeto tedioso tem outras implicações. Essa recuperação do processo de reorientação da arte como energia que movimenta a percepção. A atenção dada tanto à matéria quanto a sua inseparabilidade do processo de mudança não é enfatizado sobre o fenômeno da representação. O que é revelado é que a própria arte é uma ação de mudança, de desorientação e deslocamento, de violenta descontinuidade e mutabilidade, da vontade de confusão a serviço da descoberta de novos modos de percepção. (MORRIS, “ Notes on Sculpture 4: Beyond Objects”, 2002:872, tradução nossa) ${ }^{173}$
\end{abstract}

Os minimalista são considerados aqueles que, de algum modo, abrem e lançam as primeiras propostas e procedimentos que darão ênfase à matéria em detrimento de modelos e composições representacionais. Os pós-minimalistas se concentram ainda em fundamentos que foram lançados pelos minimalistas, entretanto atualizam colocações e sugerem perspectivas menos rígidas para a observação da matéria. Como é o caso da artista Eva Hesse, que mesmo influenciada por artistas que articularam as primeiras discussões e teses minimalistas, trabalha com materiais e estruturas menos rígidas. Uma constante em seus trabalhos é a presença de látex, fibra de vidro e plástico. Seus trabalhos insinuam linhas corpóreas, são maleáveis, flexíveis e apontam a presença do corpo. Formas orgânicas e dinâmicas que marcam a presença de esculturas como estruturas elásticas.

\title{
Materialidade, Richard Serra
}

No final da década de 60 o artista americano Richard Serra ficou conhecido por explorar a tridimensionalidade e as propriedades específicas de materiais pesados, como o aço. Entre os anos 1970 e 1980 ele trabalhou com composições relativamente simples. Eram unidades de

Control is necessary if the variable of object, light, space, body, are to function. The object itself has not become less important. It has merely become less self important. (...)" Robert Morris "Notes on Sculpture 1-3", 2002: 819, no livro "Art in Theory 1900-2000: An Anthology of Changing Ideas. Charles Harrison \& Paul Wood (org.)".

${ }^{173}$ Texto original: "The detachment of art's energy form the craft of tedious object prodution has further implications. This reclamation of process refocuses art as an energy driving to change the perception. The attention given to both matter and its inseparableness from the process of change is not an emphasis on the phenomenon of means. What is revealed is that art itself is an activity of change, of disorientation and shift, of violent discontinuity and mutability, of the willingness for confusion even in the service of dicovering new perceptual modes." Robert Morris, “ Notes on Sculpture 4: Beyond Objects”, 2002:872, no livro "Art in Theory 1900-2000: An Anthology of Changing Ideas. Charles Harrison \& Paul Wood (org.)”. 
aço que produziam uma forte presença pela sua dimensão e pelas próprias características do material. Essas estruturas avançam pelo espaço e reverberavam no ambiente físico e perceptivo do espectador.

A investigação da materialidade e da presença da matéria são algumas das características dos trabalhos de Serra e de premissas Minimalistas que irão incentivar múltiplos experimentos nessa direção. O desdobramento da noção de objeto fomentará importantes investigações da matéria e das relações que o corpo estabelece com diferentes elementos em diferente situações.

Em uma aula lecionada na Yale University em janeiro de $1990^{174}$, Serra aborda a história da escultura moderna sob a perspectiva da solda, da aglutinação de partes para a formação de um todo. As esculturas tradicionais eram compostas, em sua maioria, por pedaços que fundidos geravam uma imagem, a própria estrutura da escultura. De acordo com Serra, o que a escultura passa a investigar quando rompe com padrões e perspectivas modernistas, é a solda, não como elemento produtor de imagens ou a serviço de construções pictóricas, mas como material de construção em termos de massa, peso, contrapeso, suporte de cargas, compressão etc. O material passa a ser investigado em suas potencialidades, propriedades, possibilidades formais, estáticas e dinâmicas. O processo de produção, assim como na arquitetura, na engenharia, por exemplo, são revelados. As estruturas se apresentam de tal modo que o espectador presencia a mecânica, as juntas, os apoios, os vão e as propriedades do material. Serra pontua que a revelação do processo despersonifica e desmistifica a idealização da força ou da presença do escultor.

Sob esse ponto de vista, o que se apresenta diante dessa abordagem de Serra é um deslocamento da construção da imagem para uma investigação da matéria. A escultura se liberta do compromisso com a representação de imagens e se coloca no espaço como elemento constituinte e transformador da paisagem e do contexto geral onde ela se encontra.

Com essa transformação, o objeto, como escultura isolada em seu espaço simbólico e de representação, abandona o espaço seguro e estável do pedestal para se colocar na relação. Sua zona de ação de expande e a sua presença altera a configuração e a percepção do ambiente. Sua massa, volume, forma e matéria aparecem agora como tensão e potencialidade que gera novas movimentações e trajetos do espectador pelo espaço.

\footnotetext{
${ }^{174}$ Quando acontecimentos relacionados a polêmica história da escultura Tilted Arc, de Richard Serra, estavam em curso. A escultura foi encomendada em 1970 para a Federal Plaza em New York e removida 10 ano mais tarde. Esse episódio gerou importantes debates e reflexões sobre obra e espaço público.
} 
Condições apresentadas no contexto do Minimalismo, do Neoconcretismo e das propostas de Lygia Clark e Helio Oiticica evidenciam a presença do corpo, da materialidade, do entorno e das relações como elementos chave na construção de novas perspectivas de observação do objeto no evento artístico.

$\mathrm{O}$ objetos que antes eram quadros, esculturas e estruturas que se colocavam diante dos olhos e do olhar, se apresentam agora como formações temporárias, como lugares provisórios que convidam o espectador a interações físicas, sensoriais ou mesmo conceituais. Os objetos se espalham pelo espaço, se aderem à diferentes espacialidades e acionam o pensamento em dinâmicas que aparecem em noções como instalação, ambiente, teatralidade e performatividade. O corpo está agora comprometido com tramas espaciais que se configuram e desaparecem constantemente.

O acontecimento do objeto em sua condição temporal, rotativa e oscilante prevê ajustes sobre noções espaciais determinadas. Sob a condição instável do objeto, o conceito de coreografia, como grafia, como desenho que traça trajetos espaciais para o corpo, passa por uma importante revisão. Se os objetos são agentes, estimulam e acionam movimentos, e se esses objetos compõem ambientes e paisagens nas quais corpos, coisas e demais elementos se relacionam mutuamente, os percursos espaciais não podem contar apenas com determinações impressas ou desenhadas previamente para deslocamentos do corpo. A noção de coreografia passa a considerar as interferências que se cruzam no corpo, as linhas que fogem de arquiteturas e as pulsões ambientais que alteram rotas e levam a percepção e a paisagem para lugares imprevisíveis. A coreografia passa a ser considerada sob um ponto de vista mais amplo no qual múltiplas camadas se sobrepõem e geram desvios para o corpo e para o olhar.

A seguir apresentei condições e traços que sugerem a observação condições que se aderem a noção de coreografia e amplificam a sua observações. A noção de coreografia aparece aqui sob perspectivas que não aquelas vinculadas a fixação de normas e referenciais que fazem o corpo se deslocar no espaço.

\section{Coreografia}

Se o mundo é percebido como uma realidade construída de interações, relacionamentos, constelações e proporcionalidades, a coreografia pode assumir a prática criativa de definir tais relações, ou estabelecer as condições de tais relações, a emergirem. (KLIEN, 2008, tradução nossa). ${ }^{175}$

\footnotetext{
175 Tese Michael Klien, 2008, "Choreography as an aesthetic of change", Texto original: "If the world is perceived as a reality constructed of interactions, relationships, constellations and proportionalities, choreography can assume the creative practice of setting such relations, or set the conditions
} 
Coreografar é ato de observar linhas, volumes sólidos, estruturas voláteis, é rabisco que antecipa lugares, é tropeço que altera percursos, é desvio, passagem, porta aberta e desenho que interliga janelas e paralelepípedos. Coreografia é uma palavra composta por, pelo menos, duas outras: coreo e grafia. Palavras que falarão sobre a composição, a grafia, a escrita, o desenho. O sufixo coreo é ainda traduzido em alguns dicionários como dança. Levando-se em conta que a dança se manifesta para além dos aspectos repetitivos e previsíveis que se aderem a noções que desejam controlar passos, intensidades e deslocamentos espaciais, as escritas do corpo no espaço e as grafias que se imprimem ao corpo dão vazão a uma profusão de significados através dos quais os termos coreografia e dança passam a acontecer em diferentes interstícios e situações ambientais. Coreografar é gerar possibilidades de deslocamento, é acionar o olhar para as frestas, para as bordas, para os efeitos das texturas e cores no espaço. A coreografia que esteve por muito anos atrelada ao sinônimo de dança aparece agora como rede difusa, como emaranho complexo que mobiliza os sentidos para aventuras e incursões pelo espaço.

Dos conceitos e considerações que falam sobre o ato de coreografar, a noção que me parece mais pertinente para o contexto deste estudo, é a abordagem que leva em consideração o desequilíbrio e o surgimento de negociações que inauguração dinâmicas e trânsitos para o para o olhar e para os sentidos.

A observação da dança desvinculada de obrigações que empurram o corpo para esta ou aquela posição ou qualidade de movimento, permite a livre circulação, a demora do olhar, a respiração que se liga ao chão e a produção de novos parâmetros e formações coreográficas. Expandir a noção de dança é gerar novos desenhos para o conceito de coreografia, assim como liberar a escrita dos sentidos e frases usuais é produzir novas imagens e composições para que palavras e gestos podem ser reinventados.

Gerald Sigmund (2013) apresenta a noção de coreografia como um conceito aberto que, no contexto da dança, pode ser verificado em práticas que se pautam na ativação de elementos e potencialidades e não na fixação de instruções:

Os dançarinos já não devem mais apenas seguir instruções. Em vez disso, muitos coreógrafos contemporâneos têm se movido em direção a um "conceito aberto da coreografia" que coloca todos os elementos do "teatro" em movimento, revelando um potencial antes inimaginado do corpo. (SIEGMUND, 2013, tradução nossa) ${ }^{176}$

for such relations, to emerge." (Klien, 2008) Disponível no link: https://www.academia.edu/3809926/CHOREOGRAPHY_AS_AN_AESTHETICS_OF_CHANGE. Acesso em julho de 2015. 
Tendo em vista que os percursos e movimentos do corpo são complexos, amplos e infinitamente minúsculos, representar simbolicamente esse trajetos é tarefa árdua e que prevê inevitavelmente falhas, fracassos e variações constantes entre aquilo que é grafado em papel e aquilo que acontece no corpo. Gerald Siegmund diz que " a noção de coreografia é marcada, já em sua origem, por um "fracasso", por uma ideia de fim ao se constituir como um sistema de notação que tem como objetivo a representação simbólica e escrita de movimentos e percursos percorridos pelo corpo, como afirma Gerald Sigmund (2010:14) ${ }^{177}$. A Instabilidade como ordem potencial que se manifesta na noção de coreografia prevê perdas, deslizes e quedas que não estão previstas pela noção usual que associa o conceito à formação de passos previamente determinados.

O conceito de coreografia é hoje muito mais do que uma noção aplicada ao universo da dança apenas. $\mathrm{O}$ conceito se desdobra em múltiplas possibilidades de abordagem que podem ser utilizadas tanto em fenômenos sociais de relação e deslocamento, quanto em distribuições, condições e negociações que entram em jogo em produções e procedimentos artísticos.

O que vivemos hoje é uma transformação constante de pontos de vista que ampliam compreensões, que alargam conceitos e que se concentram em dinâmicas que promovem encontros e desafios sociais e artísticos.

O conceito de coreografia abordado por Forsythe é uma das chaves fundamentais para a compreensão das suas propostas e de características que persistem em seus trabalhos.

A coreografia, em seus trabalhos, é lugar de encontro, desenho espacial que prevê sensações e percursos inusitados que aproximam lugares, pessoas e provocam experiência singulares. Coreografia é uma noção espacial na qual o corpo pode ou não estar presente.

Susan Leigh Foster (2010), no texto "Choreographing your move" "178, apresenta uma retrospectiva histórica do termo coreografia e o localiza, no contexto atual, como uma noção ampla vinculada à ideia de regulação do movimento.

Em seu apanhado histórico, Foster (2010) nos revela com precisão as origens e as

176 Texto original: "Dancers no longer merely had to follow instructions. Instead, many contemporary choreographers have been moving towards an "open concept of choreography" that sets every part of the theatre in motion, releasing previously unimagined potential from the body." Gerald Siegmund, "What is Choreography?", 2013.

Disponível no link: https://www.goethe.de/en/kul/tut/gen/tan/20363200.html. Acesso em dezembro de 2014.

177 Disponível no texto "Five Thesis on the Function od Choreography", na Revista Score 0, 2010, disponível no link: http://tqw.at/sites/default/files/SCORES_FOLDER_final.pdf. Acesso em novembro de 2014.

${ }^{178}$ Texto que compõe o material de apresentação da exposição MOVE: Choreographing you.

Move - choreographing you: [art and dance since the 1960s] / Ed. by Stephanie Rosenthal, London Hayward, 2010 . 
transformações do termo no contexto da dança. Dois momentos principais localizam o conceito em diferentes situações, a primeira é quando o termo se refere a um sistema de notação que utiliza papel e símbolos para a descrição e a representação da dança e o segundo diz respeito a relação direta entre o nome coreografia e a própria criação em dança. Dançar e coreografar tornam-se sinônimos e esse contato fundamentará o universo da dança por muitos anos.

De acordo com Foster, a primeira noção do termo coreografia diz respeito a uma relação inovadora entre corpo, espaço e símbolo impresso.

Foster, pontua que Coreografia foi o nome dado ao primeiro sistema de notação em dança, criado por Pierre Beauchamps, mestre de dança de Luís XIV, e transformado em um sistema impresso de notação por Raoul Auger Feuillet. Coreografia era então um sistema de notação e os coreógrafos, por sua vez, eram pessoas que conheciam esses símbolos, que sabiam ler e escrever essas partituras de movimentos. Como afirma Foster, esse primeiro conceito de coreografia estabeleceu uma relação inovadora entre corpo, espaço e símbolos impressos. Documentar dança significava registrar movimentos que eram constituídos por posições, passos, quedas, giros etc.

A integração desses sinais ou registros em um suporte plano formado por símbolos transformou o corpo em um elemento vertical que se deslocaria em um plano geométrico horizontal. No contexto do sistema que notações, o corpo surge como forma bidimensional, ou como altura e largura, que atravessa um campo regido por símbolos que direcionam os movimentos e evoluções. Os símbolos se referiam apenas à direção, ao tempo e à orientação espacial do corpo no espaço. Aspectos outros e particularidades do corpo eram ignoradas no sistema de notação.

No contexto atual, estruturas que acionam e desdobram movimentos, relações entre objetos, coisas, pessoas e arquiteturas são alguns dos pontos de ligação deste traçado em expansão que hoje conhecemos como coreografia.

Noção dinâmica de difícil definição, coreografia, de acordo com Foster, se refere a qualquer estrutura de movimento, seja ela constituída por movimento humano ou não. Suas considerações inserem o conceito de coreografia em um campo bastante amplo e por vezes até mesmo indefinido. Entretanto, é essa abertura do conceito que nos permite observar e especular o fenômeno coreográfico sob diferentes perspectivas. Foster chama atenção ainda para a característica viral do termo coreografia e apresenta sua presença em diferentes contextos, como por exemplo: 
Prédios coreografam espaço e o movimento das pessoas entre eles; câmeras coreografam ações cinemáticas; pássaros desenvolvem complicadas coreografias; e um combate é coreografado. (...) e até mesmo a existência é coreografada." $(\text { FOSTER, 2010) })^{179}$

Esta perspectiva bastante dilatada do termo estende a ação coreográfica para além do campo da dança e até mesmo para além das investigações em arte. Coreografia aparece como estrutura de movimento presente em todas as instâncias do nosso dia-a-dia e da nossa existência. O modo como a arquitetura, as pessoas e as coisas se relacionam formam uma complexa rede que pode ser visualizada a partir de uma perspectiva coreográfica.

No texto "Choreographic Objects"180 Forsythe faz uma revisão do termo coreografia, que historicamente está vinculado a padrões e ao ambiente da dança, e reflete sobre este conceito como estrutura análoga a um pensamento físico. Coreografias são como potencialidades, estruturas para a interação. O que mais, além do corpo, poderia parecer um pensamento físico? É possível que uma coreografia gere expressões autônomas de seus princípios sem o corpo?, se questiona William Forsythe. E é deste modo que Forsythe investiga possibilidades coreográficas em propostas que são potencialidades de transição de um estado para o outro em qualquer espaço que se possa imaginar, sejam elas acessados pelo corpo ou não. O termo coreografia surge, na maioria das vezes, associado à ideia do corpo humano em ação. Entretanto, a partir de alguns trabalhos da série Objetos Coreográficos, Forsythe se dispõe investigar estruturas que mesmo sem a presença física do corpo evidenciam aspectos vinculados à ação e à interação. Esses trabalhos, no entanto, não fazem parte do escopo das discussões apresentadas por este estudo.

De acordo com Forsythe, resumir o termo coreografia a uma única definição é não compreender ou considerar o mais importante do seu mecanismo: resistir e reformular concepções prévias de sua definição. A palavra em si e o processo que ela descreve é alusivo, ágil e não mensurável.

De acordo com Forsythe, coreografia provoca ação sobre a ação: é um ambiente de regra gramatical regido pela lei da exceção. Coreografia é um lugar alternativo e potencial da ação de residir ou mesmo transitar.

Que caminhos são esses que os dançarinos percorrem quando estão dançando? Como que o espectador pode experimentar estímulos que provocam deslocamentos e a produção de

\footnotetext{
${ }^{179}$ Texto original: "Buildings choreograph space and people's movement between them; cameras choreograph cinematic action; birds perform intricate choreography; and a fight is choreographed. (...) and even existence is choreographed". Foster, 2010.

${ }^{180}$ Texto escrito por William Forsythe e disponível no link: http://www.williamforsythe.de/essay.html
} 
novas percepções? A coreografia aparece como um mapa que, de acordo com interações e acasos, se transformará em diferentes paisagens. Ainda de acordo com Forsythe ${ }^{181}$, "Coreografia e dança são duas práticas distintas e muito diferentes. No caso em que coreografia e dança coincidem, coreografia muitas vezes serve como um canal para o desejo de dançar."

O termo coreografia é abordado neste estudo a partir de uma perspectiva espacial que o aproxima de noções como desenhos, linha, traços, percursos, arquiteturas e trajetos que se cruzam e produzem espaços. Coreografar aqui corresponde ao ato de escrever, desenhar e propor estímulos para o movimento. Coreografia é esboço e trajeto nos quais estímulos textuais, físicos, sonoros, visuais se cruzam na construção de movimentos que estimulam a atenção, a escuta e a produção de respostas para situações e conflitos que se manifestam espacialmente.

O conceito de coreografia, de Forsythe, coincide com o desaparecimento de linhas e regras que costumam definir sistemas estáveis de organização e notação, sobretudo, no universo da dança. O que vemos em seus trabalhos, e principalmente nos mais recentes, é o surgimento de um sistema instável que contém fissuras e brechas que favorecem negociações entre corpos, objetos e arquiteturas. Negociar com o entorno e com múltiplos estímulos é ampliar possibilidades de relação em situações experimentais mais livres e desafiadoras de regras e imagens estabelecidas. Siegmund (2013) ${ }^{182}$ comenta:

Compreender coreografia como um conflito possibilita acordar e negociar regras, para, ludicamente, as testar e descobrir possíveis associações e, no processo, desenvolver corpos que contradizem as noções e imagens comuns do corpo. (SIEGMUND, 2013, tradução nossa) ${ }^{183}$

Ao promover rupturas com associações estabelecidas, a noção de coreografia se afirma como ato de compor, desenhar e apagar linhas que circulam pelo espaço e o conceito de objeto se apresenta como aquilo que aparece nas frestas da matéria. Objeto é elemento

\footnotetext{
181 Texto original: "Choreography and dancing are two distinct and very different practices. In the case that choreography and dance coincide, choreography often serves as a channel for the desire to dance." Choreographic Objects, texto de Forsythe disponível no livro "William Forsythe and the Practice of Choreography, org. Steven Spier:, 2011:90 e no link: http://www.williamforsythe.de/essay.html ${ }^{182}$ No texto "What is Choreography?" publicado do site do Goethe Institut e disponível no link: https://www.goethe.de/en/kul/tut/gen/tan/20363200.html. Acesso em novembro de 2014.

${ }^{183}$ Texto original: "Understanding choreography as a conflict makes it possible to negotiate and bargain on rules, to playfully test them and discover possible associations and, in the process, to develop bodies that contradict common notions and images of the body." (Siegmund, 2013).

Texto disponível no link: https://www.goethe.de/en/kul/tut/gen/tan/20363200.html. Acesso em abril de 2015.
} 
passível de transformações e composição que desafia o corpo ou o olhar a novas relações com a matéria. Aquilo que você conhece como cadeira é distinto da experiência cadeira em suas variações espaciais e materiais. Objeto é espaço aberto ao susto. Sob este ponto de vista, o elemento tempo se manifesta como definidor de ligações que se alteram constantemente.

A partir do momento que as noções de objeto e coreografia superam o estatuto de independência em relação ao entorno e passam a ser compreendidas como composições ou formações em andamento e processo, qualidades ambientais são enfatizadas. A partir das considerações e apontamentos tecidos nas seções anteriores e da mobilidade de perspectiva sugerida pelas variações e oscilações que compõem os eventos artísticos, as noções de objeto e coreografia parecem ganhar abrangentes entonações. E é sob essa perspectiva fluída e móvel que sugiro a análise dos Objetos Coreográficos que selecionei para esta seção: White Bouncy Castle, The Fact of Matter, Scattered Crowd, City of Abstracts, Nowhere and Everywhere at the Same time e Additive Inverse.

Suas propostas cruzam referenciais e criam espaços nos quais a apreensão de suas ideias ou propostas passam por uma complexa rede de pensamentos, reflexões e investigações que ora empurram e ora puxam o corpo para diferentes experiências. Quais os princípios que agem nesses dispositivos e provocam movimentos que se fundamentam na indeterminação e na imprevisibilidade?

\section{O que são os Objetos Coreográficos?}

Entre os projetos que surgiram com a saída de Forsythe do Balé de Frankfurt, estão os Objetos Coreográficos, quando seu interesse atravessa e extravasa a zona de atuação dos bailarinos e se lança a novas abordagem sobre o espaço, a dança, os objetos, as composições espaciais e as experiências artísticas. Nesse percurso o espectador, como presença física e perceptiva, se tornou também um de seus focos de investigação.

Os Objetos Coreográficos são como instalações, ambientes, formações e organizações espaciais e potencialidades de movimentos que podem ser produzidas e acessadas pelo espectador, que é agora participante. Geralmente expostos em bienais e exposições de arte, os Objetos Coreográficos são ambientes ou estruturas que, na maioria das vezes, solicitam a presença do corpo. Entretanto, serão os espectadores e não os bailarinos que experimentarão relações com objetos e arquiteturas. Serão os corpos dos espectadores que criarão novos acessos e lugares a partir das propostas de Forsythe. Serão esses os corpos que negociarão 
com o meio a partir da descoberta de trajetos, matérias e temporalidades. Os trabalhos são ambientes coreográficos orientados pela produção de experiências sensíveis, imagéticas e fenomenológicas.

E se considerarmos o seu percurso como coreógrafo que atuou e atua junto à companhias de balé, é possível afirmar que nesses trabalhos há um deslocamentos do bailarino, como figura central, para a afirmação e investigação da presença do espectador na produção de arte.

Coloco-me alguma perguntas: como descrever a experiência de contato com os Objetos Coreográficos? Como relatar esses trabalhos? Como construo espacialidades a partir dessas propostas? Como desenho textualmente a experiência de um objeto coreográfico? Essas são problemáticas que irei abordar nas considerações seguintes sobre alguns dos trabalhos desta série. Pretendo partir de descrições mais sensoriais e do contato com os trabalhos como modo de gerar registros que dialoguem com a experiência provocada pelas propostas de Forsythe.

Um objeto coreográfico, ou uma composição, é, por natureza, algo aberto a uma ampla variedade de investigações fenomenológicas porque ele reconhece o corpo como inteiramente projetado para ler, persistentemente, todos os sinais do seu ambiente. (FORSYTHE, 2011, tradução nossa) ${ }^{184}$

A ação da gravidade, a suspensão do corpo, o desvio e a negociação com massas de arte são considerações que dialogam com os Objetos Coreográficos selecionados para esta seção.

Na suspensão do corpo está implícito o reconhecimento do próprio peso. Na suspensão percebo minha massa corpórea e a negociação deste volume com a gravidade. Quando o corpo é suspenso o equilíbrio se altera e minha percepção se movimenta. Enquanto caminho e exerço atividades cotidianas, que não solicitam alterações radicais dos meus eixos de apoio, percebo o meu corpo sob uma perspectiva estável. O meu corpo em equilíbrio costuma produzir movimentações conhecidas e repetitivas. Percorro percursos conhecidos em um vai e vai pelo mundo.

Nos Objetos Coreográficos White Bouncy Castel e The Fact of Matter, o corpo do espectador, do participante que atua diretamente no campo fenomenológico que será gerado, é suspenso a partir de estruturas que ao elevarem a massa corporal produzem efeitos distintos. Vamos aos objetos:

\footnotetext{
${ }^{184}$ Texto original: "A choreographic object, or score, is by nature open to a full palette of phenomenological investigations because it acknowledges the body as wholly designed to persistently read every signal from its environment." ( William Forsythe, em seu texto Choreographic Objects, publicado no livro William Forsythe and the Practice of Choreography, org. Steven Spier, 2011:90)
} 
De acordo com o autor Steven Spier $(2011)^{185}$, o balé de Frankfurt não haviam ainda se apresentado na Grã Bretanha quando William Forsythe foi sondado, em 1993, sobre a possibilidade de produzir um trabalho que viria a ser conhecido como White Bouncy Castleque originalmente foi chamado de Tigh Roaring Circle.

No dia 26 de março de 1997 o trabalho, que contou com a colaboração de Dana Caspersen e Joel Ryan, estreou em Londres, na The Roundhouse, uma construção de 1846 que é hoje um espaço de arte.

White Bouncy Castle, o castelo elástico branco, consiste em uma estrutura inflável e flexível produzida em material branco e no formato de um castelo. O público é convidado a entrar e percorrer essa estrutura em uma ambientação que conta com a composição sonora produzida por Joel Ryan. De acordo com o texto de apresentação do trabalho ${ }^{186}$, a coreografia que aparece, conduzida pela trilha sonora de Ryan, é o resultado da completa desestabilização física e do absurdo social decorrente.

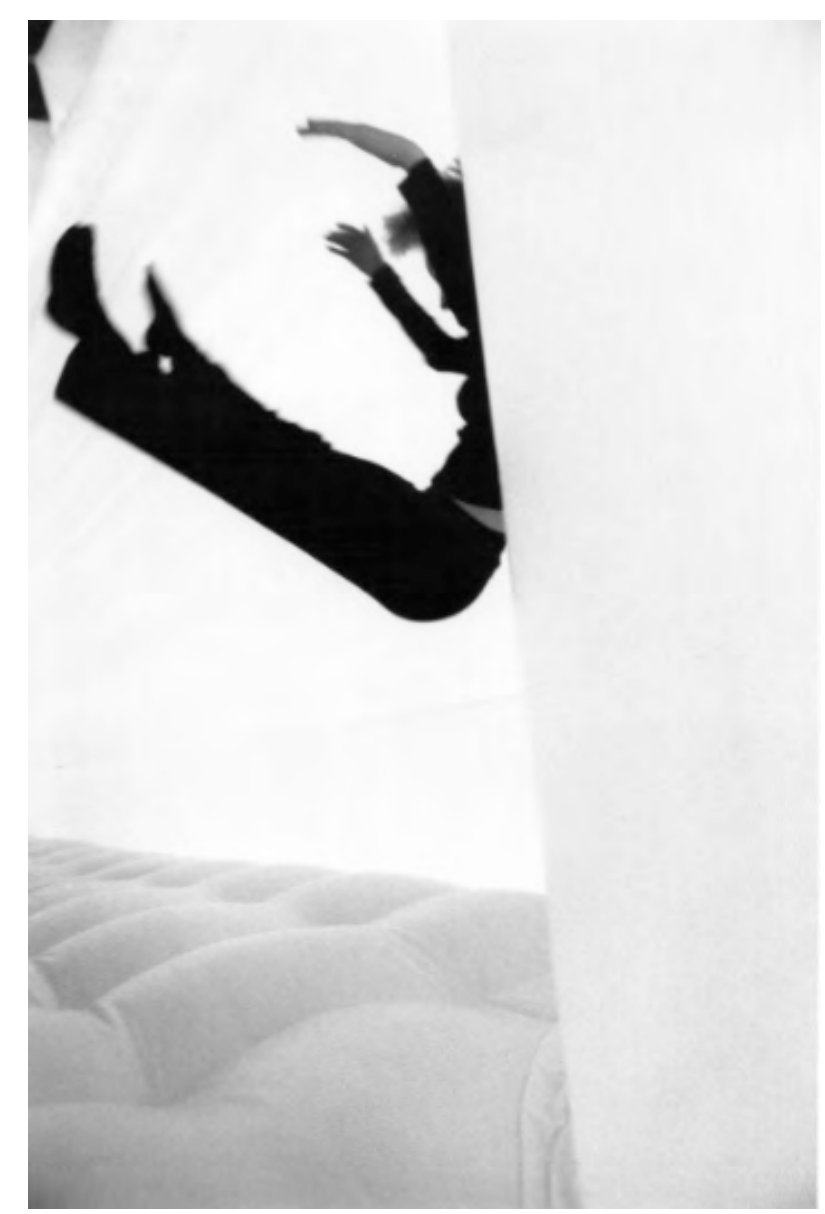

White Bouncy Castle

\footnotetext{
${ }^{185}$ No texto "Choregraphic thinking and amateur bodies", no livro William Forsythe and the Practice of Choreography, 2011.

${ }^{186}$ Texto disponível no site de William Forsythe, no link:

http://www.williamforsythe.de/installations.html?\&no_cache=1\&detail=1\&uid=30
} 
A estrutura inflável lança o corpo para cima, altera o equilíbrio e provoca novas negociações do corpo com o chão e com o ar. Este ambiente aéreo suspende o corpo, torna a massa corporal mais leve e age na construção de novos mecanismos de apoio. O corpo em contato com o ar, em suspensão, ou quando toca o castelo elástico é menos estável, negocia com oscilações e desequilíbrios ao mesmo tempo em que se percebe mais leve. Os saltos são provocados por impulsos resultantes da movimentação dos corpos que compartilham este espaço vertiginoso e pela própria ação do material e das massas de ar que agem sobre o corpo. Os pontos de apoio se multiplicam e se dispersam em um ambiente no qual os ponto de fuga se movimentam em órbitas desconhecidas.

$\mathrm{O}$ ambiente aciona até mesmo aqueles que decidem se sentar dentro da estrutura. A reverberação dos corpo em movimento e a ação provocada pelo castelo estimula ativações em diferentes níveis. Há uma ativação física e direta que age na reorganização do modo como percebo meu próprio corpo. Os vetores que jogam o corpo para o alto permanecem agindo sobre a percepção mesmo quando o participante sai do castelo e pisa novamente o chão firme. Sensações são acionadas nesses intervalo de contato com o ar, nesses saltos que deixam o corpo mais leve e livre das condições impostas pela gravidade nos deslocamentos cotidianos. O corpo agora se lança ao imprevisto, ao acaso, fica mais leve, mais desajeitado e encontra novas possibilidades de se mover.

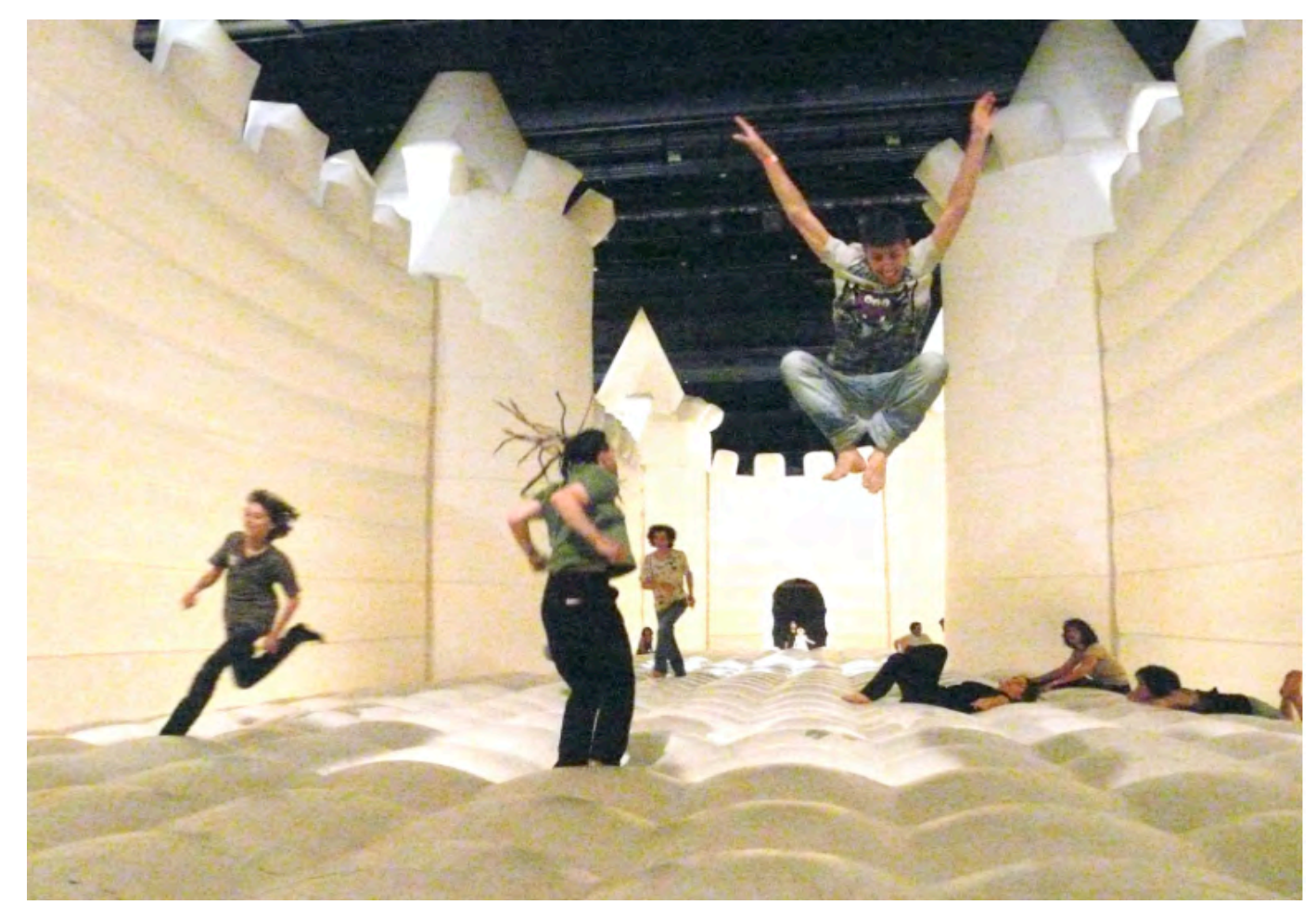

White Bouncy Castle 
Forsythe comenta a experiência deste trabalho:

\begin{abstract}
Para nós foi uma coisa extremamente interessante e maravilhosa estar no castelo, nesta sala de não-espectadores, apenas participantes, e experimentar o surgimento de uma coreografia que não poderia ser falsa. Não seria nunca falsa porque os parâmetros de desestabilização, a inclusão inevitável do acaso, o enorme absurdo e o fato de que o castelo levou você a se mover de uma certa forma criou uma situação onde não havia espaço para ações que não estivessem ligadas ao presente. Isto é reação autêntica, algo que muitas vezes se perde nos rigores do mundo do balé, e sem o qual o balé é ainda totalmente sem sentido. (FORSYTHE em Sulcas, 2011:13, tradução nossa) ${ }^{187}$
\end{abstract}

No trabalho The Fact of Matter, a suspensão do corpo se dá pela força e habilidade em suportar o próprio peso e coordenar movimentos que permitam ao participante transitar entre argolas que são penduradas no teto. O contato com o ar e o afastamento do solo solicitam aqui um esforço extra e tomadas rápidas de decisão para que o corpo permaneça suspenso e em contato com o objeto.

The Fact of Matter foi criado em 2009 e apresentado na Bienal de Veneza. Desde lá o trabalho já esteve presente em inúmeras exposições e mostras de arte.

Neste trabalho inúmeras argolas são penduradas por fitas que suportam o peso de até dois corpos. As argolas suspensas ficam próximas e o participante deve atravessar a sala através desta estrutura. É preciso se pendurar, ir de uma argola para a outra, com o apoio dos pés e das mãos, e encontrar meios de avançar para chegar do outro lado da sala. A tarefa é árdua e exige força, coordenação, flexibilidade e atenção em relação ao trajeto e a escolha das argolas para a transferência do peso e movimentação do corpo.

Em conversa ${ }^{188}$, Forsythe diz que nesse trabalho é possível perceber qualidades e características bastante particulares de cada corpo. Os participantes se são conta de, basicamente, três aspectos, assim descritos por Forsythe: "um: você não é tão leve quanto pensa, dois: não é tão coordenado e três: não é tão forte". Como o próprio nome do trabalho insinua, o que acontece com o participante é uma revelação ou um contato com fatos e circunstâncias que se manifestam na matéria (The Fact of Matter - na realidade, de fato, etc.), na prática, e que não percebemos em nossa movimentação cotidiana.

Neste trabalho a suspensão prevê também a mudança e a transferência de pontos de

\footnotetext{
${ }^{187}$ Texto original: :It was for us an extremely interesting and wonderful thing to be in the castle, in this room of no spectators, only participantes, and experience the arising of a choreography which was incapable of being false. Is was never false because the parameters of destabilization, unavoidable inclusion in the event, the sheer absurdity and the fact that the castle led you to move in a certain way created a situation where there was no room for actions that were not connected to the present. This is authentic reaction, something which often gets lost in the rigours of the ballet world, and yet without which ballet is utterly meaningless." (William Fosrythe em Sulca, 2011:11)

${ }^{188}$ Conversa pública que aconteceu no dia 18 de novembro de 2015 em evento no MMK, em Frankfurt.
} 
apoio. O corpo negocia com as argolas e com as fitas que as suspendem. Os pés que se apóiam nas argolas oscilam e a instabilidade deste ambiente gera tensões que dificultam a realização da tarefa sugerida pelo trabalho. Atravessar a sala sob as condições apresentadas por este objeto requer tomadas de fôlego, movimentos que fazem o corpo avançar e recuar, exige atenção aos eixos e aos novos pontos de equilíbrios que são gerados na passagem de uma argola para outra. A respiração aqui fica ofegante, o ar mais curto e a força da gravidade age deliberadamente sugerindo que o corpo volte a tocar o solo. É preciso persistir, silenciar, tentar novamente, dar alguns passos à frente e voltar. As direções se multiplicam e os percursos não são nada óbvios. O corpo precisa experimentar o objeto, as forças que mantém a suspensão e aprender a lidar com aquelas que forçam o corpo a tocar o chão. $\mathrm{O}$ ar e a suspensão estão aqui associados com um esforço extra e a convocação de forças e relações desconhecidas para muitos que participam ou que tentam participar deste trabalho. As argolas geram oscilações, desestabilizações e desafiam o corpo a encontrar novas organizações em momentos de suspensão.

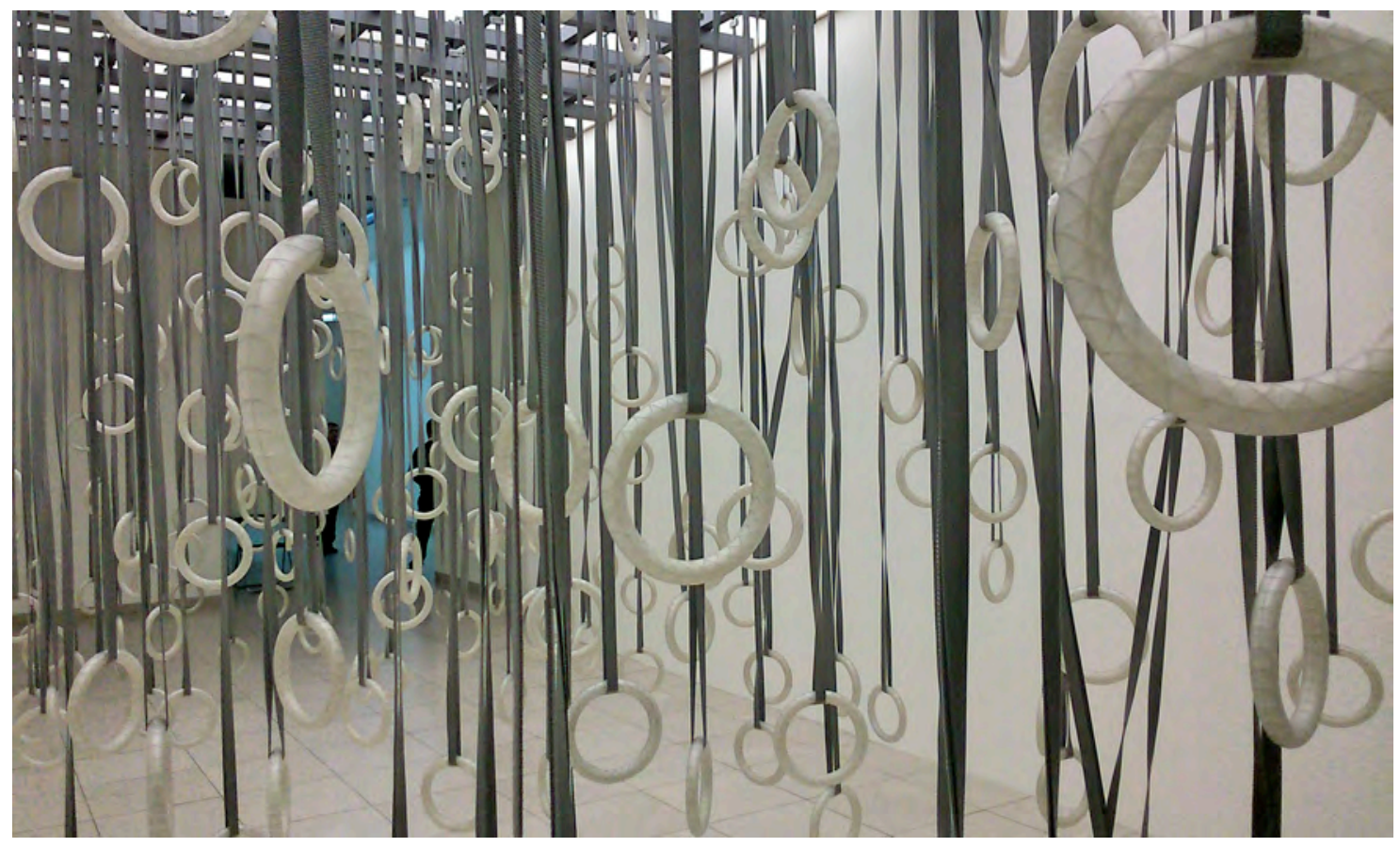

The Fact of Matter, 2015

Nos trabalhos White Bouncy Castel e The Fact of Matter, referenciais físicos, matemáticos e atmosféricos agem diretamente sob a massa corporal e provocam ativações na percepção, no modo como o corpo se organiza, se relaciona e produz espaços. Os mecanismos são distintos, enquanto em um o corpo aparece mais leve e descolado do solo, no outro ele 
aparece mais pesado e tendendo a tocar o solo no primeiro deslize, na primeira tomada de decisão apressada que o faça se desgrudar das argolas. A suspensão nos dois trabalhos descola o corpo do chão, gera trajetos atmosféricos e prevê a reorganização e a descoberta de equilíbrios que acontecem em situações inesperadas ou incalculáveis sob o ponto de vista de uma perspectiva euclidiana na qual o ponto de apoio é fixo e orientador das paisagens que conhecemos.

As paisagens nesses trabalhos são precárias, dispersas e frágeis. Elas se constroem à medida que os corpos interagem com o entorno e descobrem novas possibilidades de movimentação. Descobre-se também, nos contextos analisados, os pontos em que o corpo fracassa na execução de tarefas, o momento em que impossibilidades se impõem e geram novas ordens, desvios. As falhas, aquilo que não se dá de acordo com o esperado produz tonalidades desconhecidas e aciona linhas imprevisíveis na relação que o corpo estabelece com o ambiente.

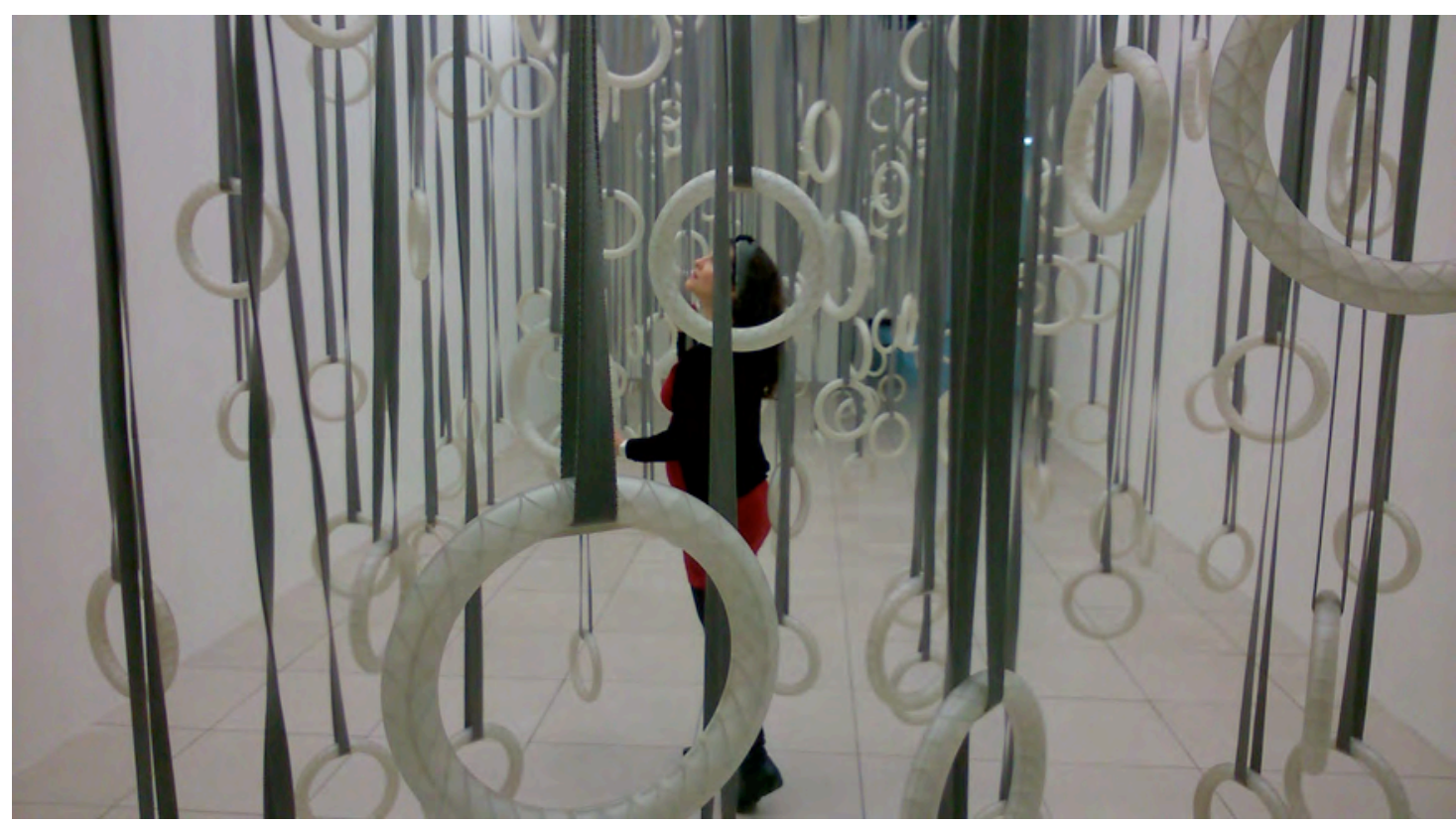

The Fact of Matter, 2015

Se propusermos a observação da dança sob o ponto de vista das experiências provocas por esses dois trabalhos, é possível afirmar que dançar já não coincide com a execução de movimentações estáveis que conduzem o corpo para este ou para aquele lugar. Dançar aqui implica novas variações, a desarticulações de estruturas e a instauração de um campo dinâmico que conta com quedas, falhas, impossibilidades, organizações, imprevisibilidades e desorganizações. 
No que diz respeito a esse assunto, o autor André Lepecki (2006) ${ }^{189}$ fala da desmontagem de analogias e conceitos estáveis como um modo de esgotar o conceito de dança dos referenciais já conhecidos e associados a padrões repetitivos que determinam posições e temporalidades. Vincular dança a um sistema contínuo e sistemático de movimentos é limitar reflexões fundamentais e ontológicas a seu respeito.

A dança moderna, por exemplo, estava associada a estruturas cinéticas, ao movimento incessante e contínuo. Entretanto, é na desaceleração e na reestruturação de ordens que novas perspectivas e possibilidades para os eventos são produzidas.

Na medida em que o projeto cinético da modernidade torna-se a ontologia da modernidade (sua realidade inescapável, a sua verdade fundamental), o projeto de dança ocidental se alinha cada vez mais com a produção e a exibição de um corpo e de uma subjetividade aptos para executar esta mobilidade ininterrupta. (LEPECKI, 2006: 17 , tradução nossa) ${ }^{190}$

A abordagem da dança no contexto contemporâneo leva em consideração sua alteridade, sua imprevisibilidade e as forças que estimulam a criação de novos ângulos de observação sobre o seu acontecimento.

Os dois objetos a seguir permitem ainda considerações sobre qualidades exercidas pelo ar, pelo contato de volumes de ar com a pele. Entretanto, Scattered Crowd e Additive Inverse, propõem incursões atmosféricas nas quais as suspensões acontecem em experiências que enfatizam qualidades temporais. Os impactos físicos são aqui mais sutis. $\mathrm{O}$ ar assopra a pele, se materializa e propõe o aparecimento de tempos mais lentos.

Scattered Crowd ou "multidão espalhada” é um trabalho de 2002 que vem sendo apresentado em diferentes arquiteturas e contextos. Neste trabalho, uma sala ou um espaço delimitado é invadido pela presença de balões brancos que são dispersos e suspensos pelo espaço. Uma paisagem frágil, delicada e aérea é apresentada aos corpos que transitam pelo espaço instalativo proposto por Forsythe. Uma composição sonora acompanha os balões em órbita.

William Forsythe ${ }^{191}$ comenta as duas versões deste trabalho. Na primeira versão os balões são dispostos em uma sala pequena e as pessoas precisam evitar o contato com os

\footnotetext{
${ }^{189}$ No texto “Agotar La danza”, de André Lepecki, 2006.

${ }^{190}$ Texto original: "En la medida em que el proyecto cinético de la modernidad se convierte en la ontologia de la modernidad (su ineludible realidad, su verdad fundacional), el proyecto de la danza occidental se alínea cada vez más con la producción y la exhibición de un cuerpo y una subjetividad aptos para ejecutar esta imparable motilidad." (Lepecki, 2006:17)

${ }^{191}$ Em entrevista realizada no dia 25 de março de 2015, em Frankfurt.
} 
volumes de ar, na segunda versão os balões aparecem em amplos salões e os visitantes devem organizar o ambiente interagindo com esses objetos aéreos.

As duas situações geram, de acordo do Forsythe, diferentes qualidades de relação. Se na primeira versão é preciso evitar o contato e procurar meios de desviar dos balões, na segunda a manipulação desses volumes de ar faz que com as pessoas executem movimentos muito lentos e cuidadosos. Diferentes tempos se instauram. Entretanto, o estado de alerta e o olhar atento ao entorno são condições e qualidades que compõem a orquestração desses ambientes.

Este ambiente gera movimentos que se entrelaçam em tramas nas quais o corpo observa e toca em vazios, formas, proximidades, distâncias e sensações que alteram o compasso do tempo. Formas voláteis, a temperatura, os volume e as massas de ar que deslocam o corpo e são por ele deslocadas. Os trajetos do ar, o tempo ao contrário e os ponteiros de relógio marcando intervalos mais lentos.

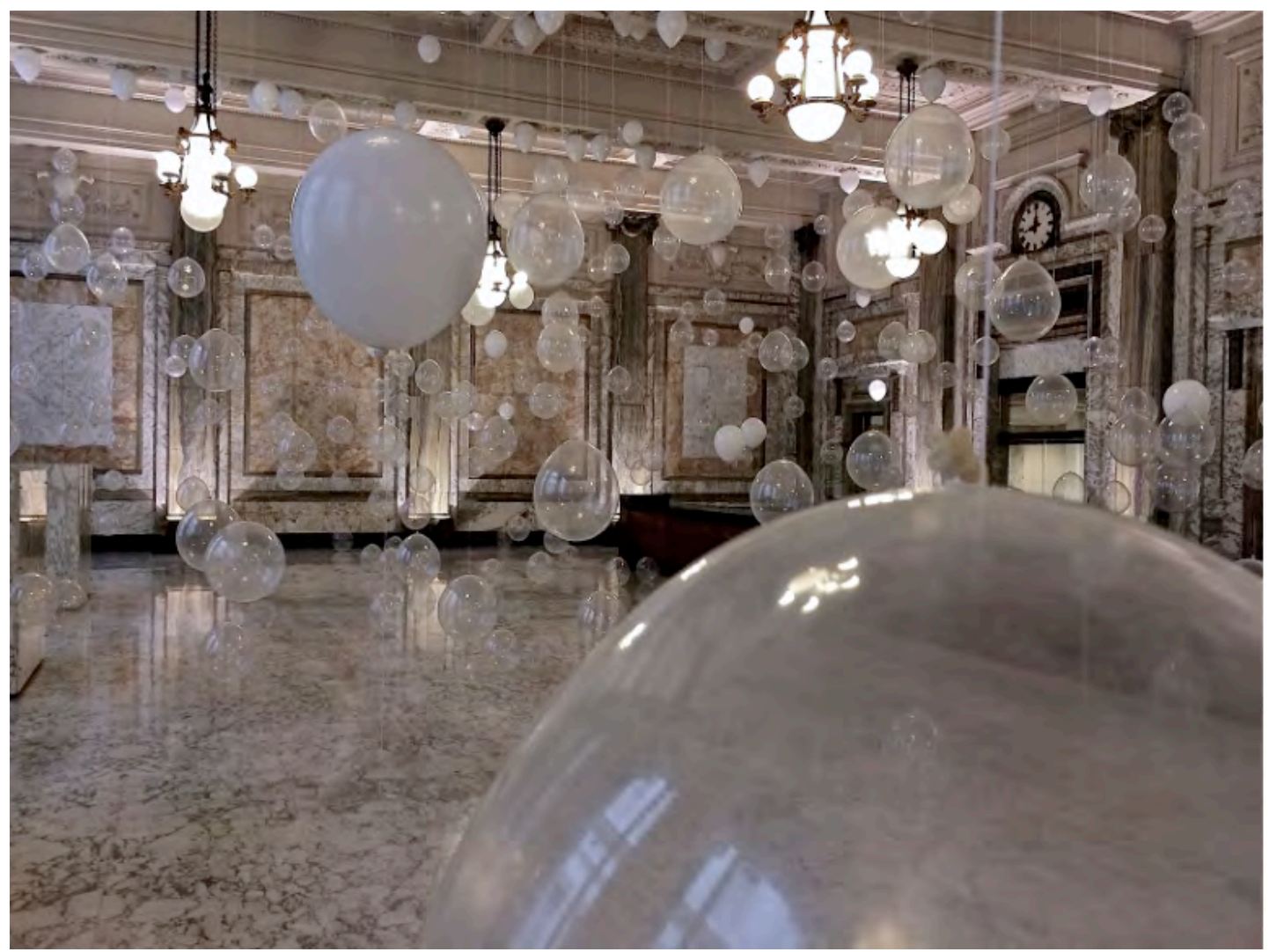

Scattered Crowd

Desacelerar e experienciar novas relações com o tempo cotidiano coincide com o acionamento de qualidades frágeis e sutis que se revelam na matéria, no ambiente e nas ligações que aproximam e dispersam elementos e estímulos. A respiração, o ar e os volumes que negociam constantemente com o corpo provocam alterações na fala, no deslocamento e 
na configuração dos ossos, das contrações e expansões da pele.

Additive Inverse, de 2007, confunde os limites entre escultura, desenho e filme. $\mathrm{O}$ trabalho foi apresentado pela primeira vez em Tóquio, em uma mostra de $\operatorname{Design}^{192}$, e conta com projeções e uma estrutura por onde circula gelo seco.

Na versão de 2015, a sala onde o trabalho é montado é escura e logo na entrada há a indicação de que os visitantes devem se mover com cuidado pela sala para que suas presenças não influenciem na atmosfera. Mover-se com cuidado é evitar que o ar se mova, que a massa de ar que circula pela estrutura não seja perturbada.

"O contrário de adicionar", que seria uma tradução possível do título do trabalho Additive Inverse, joga com a ideia da eminência do desaparecimento. A movimentação dos visitantes, dentro da sala onde está a instalação, pode fazer com que o trabalho desapareça. As pessoas precisam se mover de forma mais lenta. Devem permanecer atentas aos deslocamentos de ar que se tornam visíveis no volume de fumaça concentrado no centro da sala e dentro da caixa onde são projetados três vídeos. O trabalho é perda, é sistema prestes a desaparecer e é o oposto da somatória e da fixação que compõe formas subordinadas a um suporte estável.

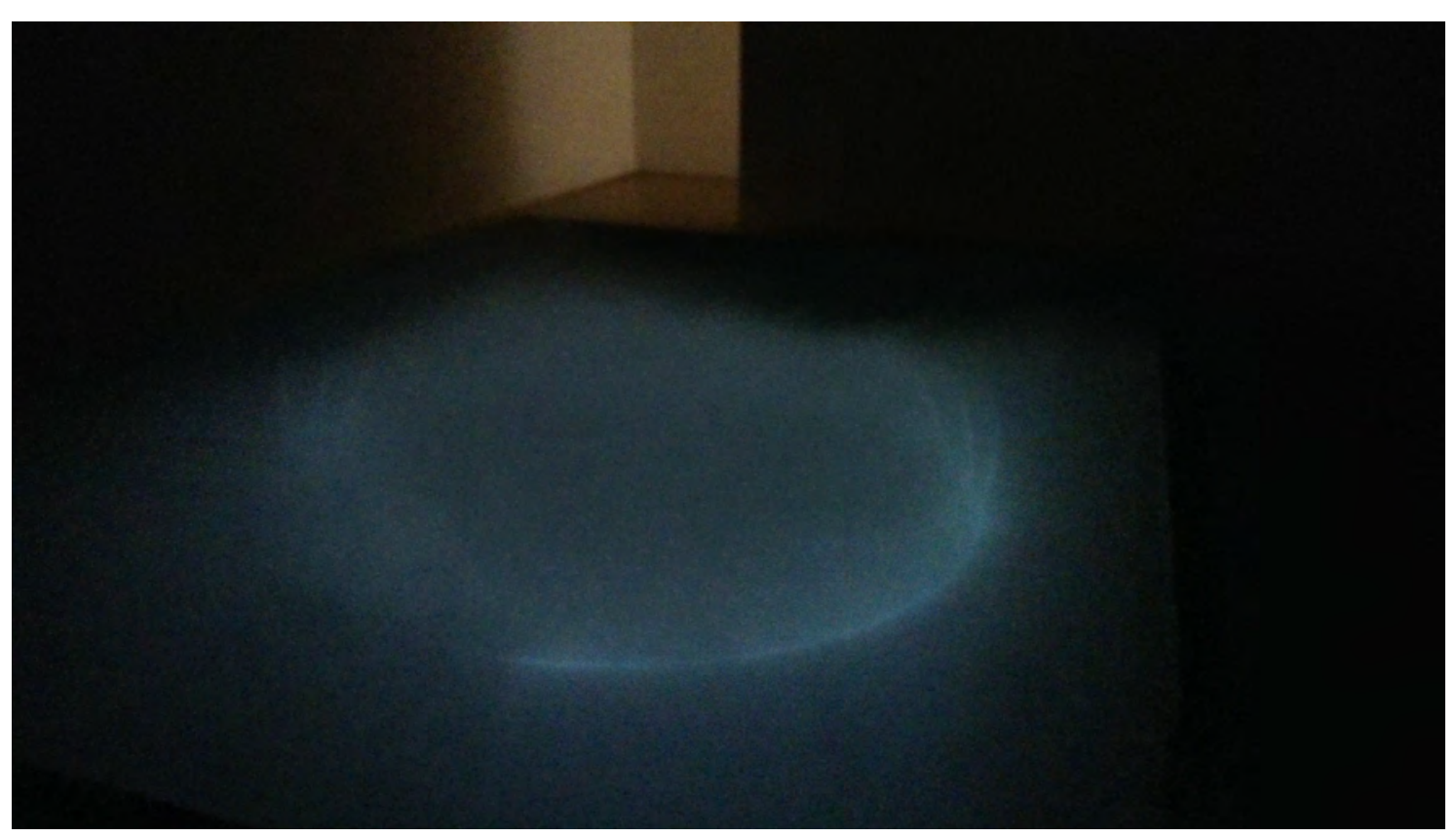

Additive Inverse, Arquivo pessoal. MMK, Frankfurt, 2015

A fragilidade da paisagem proposta pelo trabalho se expressa na desaceleração dos

192 Sobre a mostra: http://www.2121designsight.jp/en/designsight/ 
corpos que se aproximam do objeto. O espaço, a arquitetura, o silêncio e os movimentos mais lentos são agora qualidades e linhas frágeis que podem ser assopradas, que saltam aos olhos como matéria densa, sutil e suscetível às variações provocadas ao caminhar.

Ar é matéria viva que encosta na pele e a indicação de não perturbar o ambiente passa a soar como um desafio. Os visitantes querem deslocar o ar, querem assoprar e perceber o momento em que a massa atmosférica desvia de sua rota circular e avança pelo corpo. A sensação do fino, do delicado, do sutil e da fragilidade que atravessa a percepção acontece quando o corpo descobre variações temporais a partir da pressão do ar sobre a pele.

Em Scattered Crowd e Additive Inverse os impactos físicos são delicados, acontecem na superfície da pele, nos movimentos lentos que se manifestam em balões brancos que cruzam a sala ou na fumaça densa que escapa de uma área delimitada e encosta o corpo. A respiração fica mais lenta, a pressão do ar desliza pelo espaço enquanto o corpo acompanha os trajetos em silêncio.

Uma pausa se impõe entre o olhar-corpo e os estímulos provocados pelo ambiente. Nesses trabalhos a suspensão se dá no tempo, na percepção e na possibilidade de explorar a duração, a matéria e os tremores da memória que respiram pela pele.

As qualidades sugeridas por esses trabalhos acontecem no encontro do corpo com condições e flutuações ambientais. O tempo se expande, se contrai e as marcações que classificam e recortam o tempo em fatias e porções encapsuladas se transformam em linhas contínuas que avançam, que sobrevoam e despertam a atenção para movimentações demoradas, para flutuações que jogam o olhar para a ponta dos dedos e desafiam o corpo a respirações mais longas e pausadas.

Sobre a experiência de um tempo mais lento, cito ainda a versão The City of Abstracts exposta no Museu de Frankfurt, em 2015. Para tanto, farei antes algumas colocações que favorecem a observação deste trabalho no contexto da produção de arte contemporânea.

Deslizes, quedas e os mais variados estímulos passaram a fazer parte dos caminhos e dos processos de aproximação e relação do público com a obra. E é nesse exato momento que os conceitos de público e obra são revisados e colocados em questão.

Uma das grandes viradas na transferência do foco de atenção das metáforas para a matéria, foi a constatação e o estímulo da experiência do tempo como fenômeno que produz faíscas nos sentidos. O tempo em suas variações espaciais e físicas gera interferências na percepção. A temporalidade altera padrões, ela se expõe nas transformações e perturbações físicas. 
A temporalidade, o fenômeno, a matéria que se sobrepõe à metáfora e à constatação de que os eventos acontecem no tempo e no espaço provocam importantes considerações sobre a indeterminação e os processos dinâmicos verificáveis em procedimentos artísticos. Neste sentido, a ação do tempo e a duração são condições e qualidades que se manifestam no movimento e podem ser observadas como um dos fatores decisivos na construção de relações possíveis entre obra e espectador.

Marcel Duchamp, que é muitas vezes inserido de modo restrito a um universo conceitual da arte, vai além do conceito e da experiência intelectual ao promover discussões que alargam as possibilidades estéticas na produção de arte.

Uma das noções apresentadas por Duchamp é o "retardo". Ele faz uso desse conceito para tratar do trabalho A noiva despida por seus celibatários, mesmo ou O Grande Vidro (1915-23) ou ainda "atraso em vidro" e fugir da classificação habitual da pintura. Este trabalho de Duchamp propõe infinitas abordagens tanto sobre a sua narrativa quanto sobre os elementos e qualidades presentes na enorme estrutura de vidro produzida pelo artista. $\mathrm{O}$ vidro, aliás, funciona aqui como passagem, como furo, como lugar que é atravessado pelo olhar do espectador. A transparência permite contatos entre o trabalho e o espaço expositivo. $\mathrm{O}$ material vidro, diferentemente das telas usuais da pintura, incentiva acesso ao avesso, a uma experiência espacial na qual o movimento e o tempo são qualidades fundamentais em sua proposta. Claudia Duarte ${ }^{193}$ no texto "Marcel Duchamp, olhando o Grande Vidro como interface" cita as palavras de Duchamp:

\begin{abstract}
Como suporte, o vidro me interessava muito devido à sua transparência. Isto já era bastante. E além disso a cor, quando aplicada sobre o vidro é visível do outro lado, e perde a possibilidade de oxidar, se a fechamos hermeticamente. A cor permanece com sua aparência pura por tanto tempo quanto é fisicamente possível. Com o vidro você pode se concentrar na figura se você quiser, e pode trocar o fundo se você quiser, movendo o vidro. A transparência do vidro atua por você. A questão da pintura num fundo é desgastante para o pintor. A coisa que você quer expressar não está no fundo. (DUCHAMP apud DUARTE, 2000)
\end{abstract}

Entretanto, o que me interessa destacar neste trabalho é aquilo que Duchamp chama de "retardo" - um tempo que decorre em uma duração mais lenta ou mesmo a possibilidade de criar relações nas quais as qualidades temporais e transitivas suspendem as associações imediatas que confirmam definições tradicionais da pintura. O "retardo" de Duchamp prevê movimento, duração e um tempo que provoca a mobilidade do olhar. Essas condições alertam

\footnotetext{
${ }^{193}$ Cláudia Duarte em "Marcel Duchamp, olhando o Grande Vidro como interface”, Rio de Janeiro, Rios Ambiciosos, 2000:42,43.
} 
os sentidos para características da matéria em seu processo contínuo de atualização. O "retardo" confronta a ideia com uma presença física e temporal.

Essa temporalidade presente na ideia de "retardo" aparece anos antes no trabalho $\mathrm{Nu}$ descendo a escada, de 1912. O trabalho foi rejeitado pelos cubistas por trazer em sua composição indícios temporais que não cabiam nas regras colocadas pelo Cubismo. As regras de decomposição da imagem em fragmentos, colocada pelos cubistas, ganha agora um novo elemento, o tempo, como condição que fará a pintura se movimentar em novos compassos. $\mathrm{O}$ tempo em desaceleração, o retardo, apresentado por Duchamp neste trabalho permite a observação do movimento em seu trajeto. Duchamp coloca o espectador em contato com uma nova articulação temporal que prevê a mobilidade que se manifesta na matéria, no movimento. O olhar se movimenta com o corpo nu descendo a escada. Tempo e movimento se sobrepõem e se produzem mutuamente. A temporalidade que é assumida na relação com a matéria, em Duchamp, será um dos temas e assuntos que o Minimalismo mais tarde irá explorar.

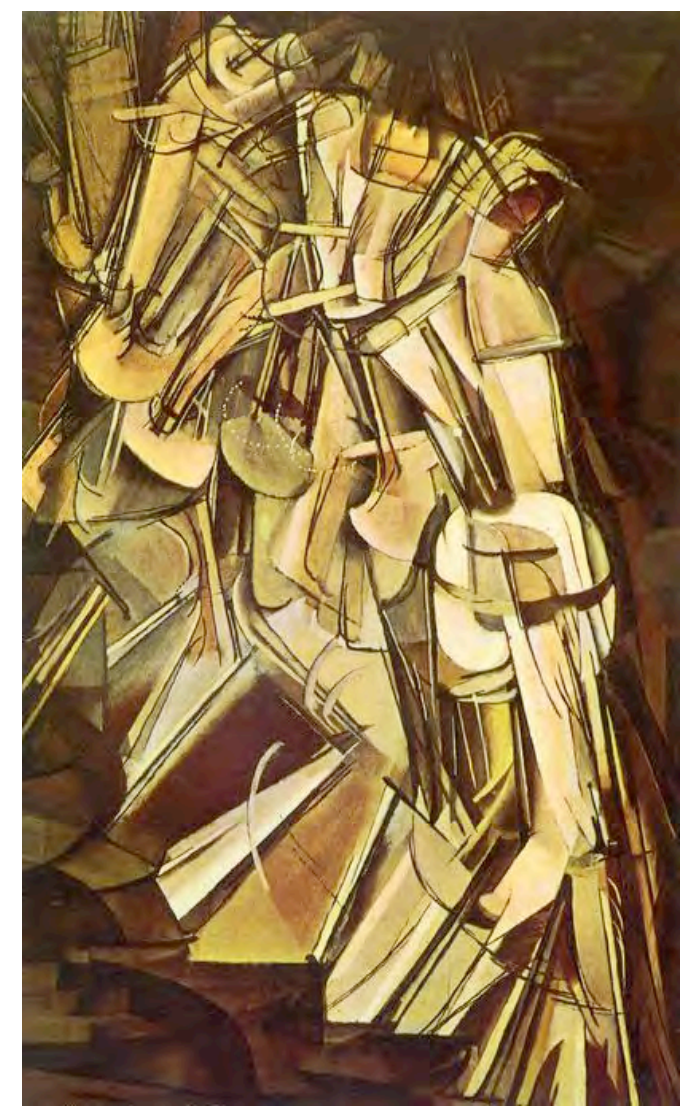

Nu Descendo a Escada, 1912, Marcel Duchamp

Valendo-me das considerações acima sobre o tempo como duração e condição que se manifesta no movimento e da noção de dissenso que Andre Lepecki apresentada no texto 
"Coreopotícas e Coreopolícias" - abordado na seção Lugares em Construção, que trata dos trabalhos de Forsythe em espaços públicos - apresento o trabalho City of Abstracts no contexto da exibição The Fact of Matter em um museu de arte ${ }^{194}$.

Logo no hall de entrada o tempo recua. Os ponteiros do relógio voltam no tempo e os meus primeiros passos dentro do museu podem ser vistos sob a perspectiva de um jogo que aciona tempos passados, futuros e presentes. Diante de um enorme monitor o caminho que percorri é distorcido em imagens e tempos nos quais me vejo em pedaços, em curvaturas que me possibilitam ver o tempo agindo na movimentação do meu corpo. Uma espécie de decomposição do movimento é proposta pela tela que se impõe na entrada da exposição The Fact of Matter.

Os recursos tecnológicos deste trabalho estão baseados em algoritmos que causam distorções na imagens captadas e provocam oscilações na percepção do tempo.

Assim que percebem os efeitos que estão sendo produzidos por esse dispositivo, os visitantes param. Passam a investigar as variações que aparecem na imagem. Experimentam fazer o caminho novamente, rodopiam, gesticulam, se aproximam e se distanciam enquanto interagem com a projeção e com efeitos que aparecem na tela. Nesse processo, logo percebem que não estão sozinhos e que fragmentos de outros corpos e movimentos se incorporam e se fundem aos seus. Jogam com as regras e testam possibilidades que revelam passagens do tempo, o corpo que se move e que observa em seguida os trajetos tortos de movimentos. $\mathrm{O}$ rápido e o lento, aquilo que eu faço e a suspensão para a observação das linhas que se cruzam no espaço em traços e rabiscos temporais.

A tensão gerada pela proposta do trabalho dribla, de algum modo, os padrões habituais de comportamento dentro de um museu de arte ao provocar um impacto físico que rompe com as regras e os limites institucionais que ainda hoje se impõem nessas instituições.

City of Abstacts gera, na entrada da exposição, um certa dinâmica de dissenso na qual o impacto perceptivo que joga com a noção de tempo, de passagem e movimento provoca perdas súbitas de orientação e fazem com que o corpo que visita o museu experimente paragens, tempos que suspendem o ritmo dos relógios. O dissenso aqui está na suspensão de uma temporalidade cotidiana ou mesmo institucional que aparece na relação com as imagens que são produzidas entre o corpo e a tela.

\footnotetext{
${ }^{194}$ O exemplo de se refere à exibição do trabalho na exposição The Fact of Matter, que aconteceu no MMK, em Frankfurt, entre 2015 e 2016.
} 
O que Forsythe ${ }^{195}$ destaca na proposta deste trabalho é o estado investigativo que é despertado. As pessoas passam a investigar movimentos, tempos, o funcionamento desses algoritmos que agem no espaço interferindo nas lógicas temporais de observação do corpo e do movimento.

As imagens se convertem em rastros que perturbam as definições de início e fim. $\mathrm{O}$ retardo imprime uma temporalidade distinta ao evento e fornece dados para a observação de linhas contínuas que perambulam pelo espaço.

Nesta versão, se comparada àquela que acontece em passagens públicas, a investigação do movimento se sobrepõe ao susto que acontece quando este trabalho acontece nas ruas.

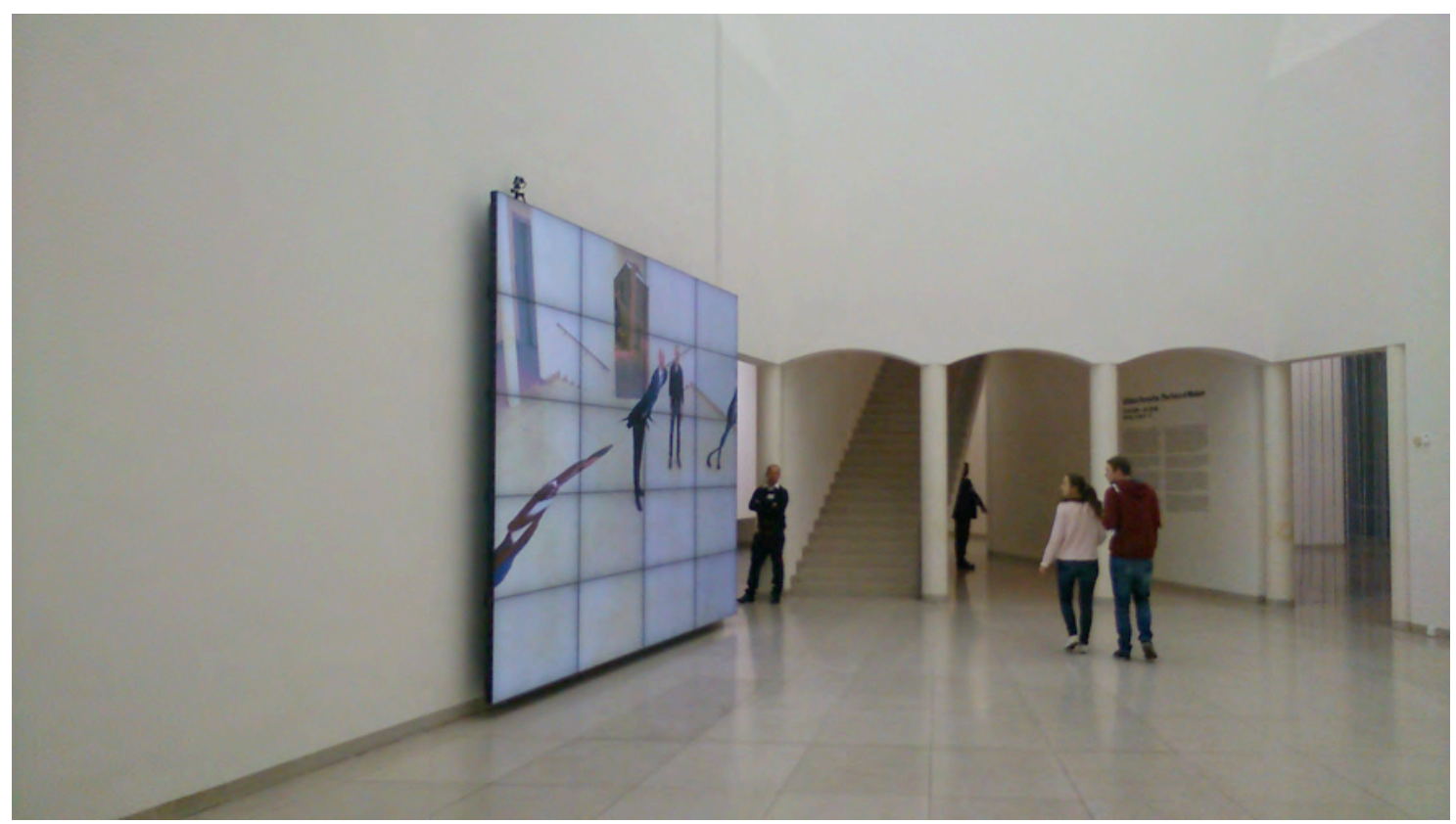

City of Abstacts, 2015. Arquivo pessoal

\footnotetext{
${ }^{195}$ Forsythe fala sobre este trabalho em uma conversa pública que aconteceu no dia 18 de novembro de 2015 no MMK, em Frankfurt.
} 


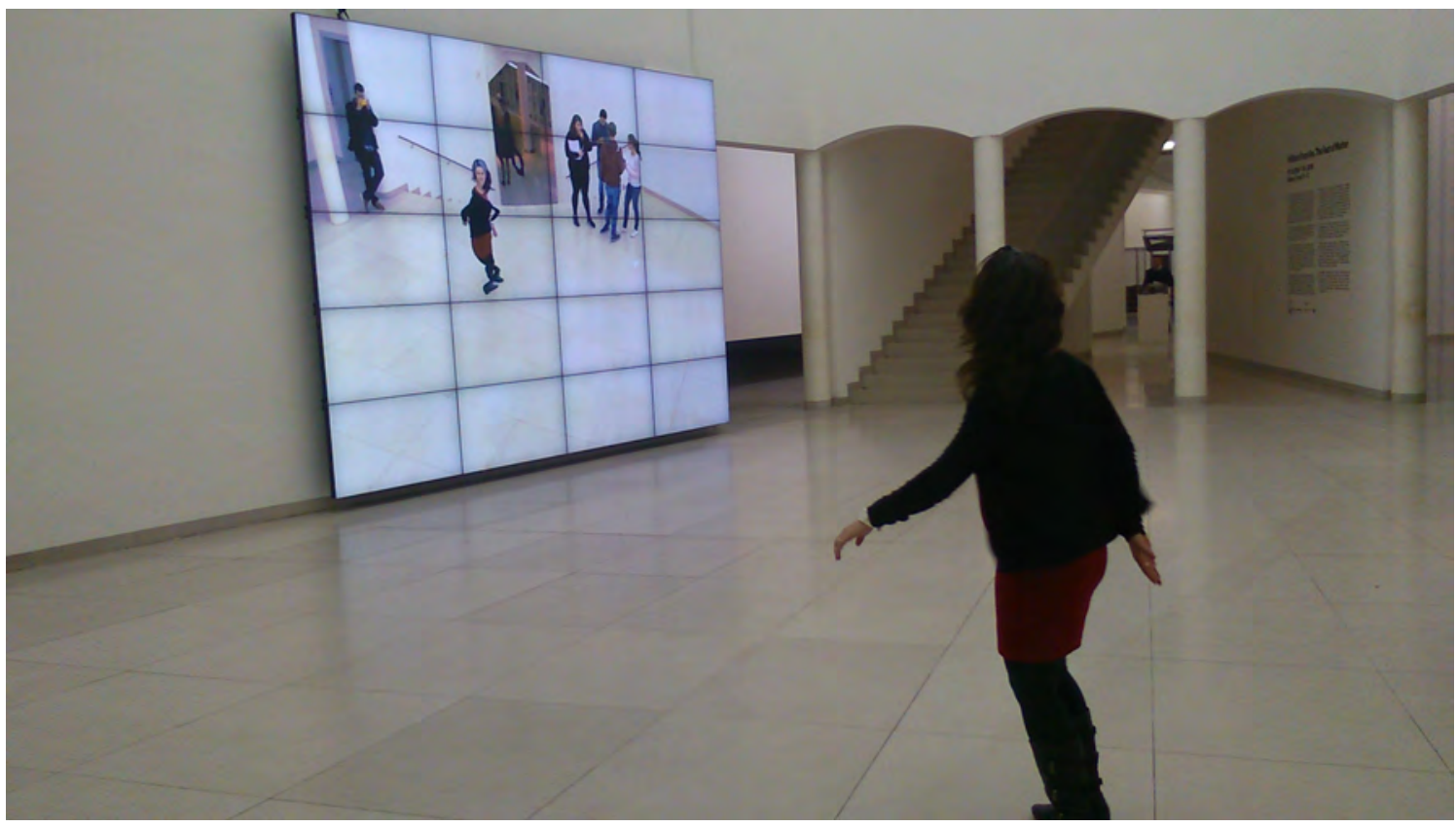

City of Abstacts, 2015. Arquivo pessoal

Os trabalhos acima, desde White Bouncy Castle, abordam relações diretas do meio com o corpo, com a fisicalidade e com as faculdades perceptivas. A ampliação do campo perceptivo conta, nos exemplos acima, com o emprego de referenciais de diferentes áreas do conhecimento. Leis da física, tecnologias, recursos de áudio e programas de computação que produzem partituras sonoras são alguns dos mecanismos que entram em ação e na execução dessas propostas.

As sonoridades, mencionadas na descrição de White Bouncy Castle e Scattered Crowd, interferem e produzem qualidades particulares no contato dos participantes com os trabalhos. Contudo, interessou-me enfatizar nesses trabalhos aspectos que tratam do ar, da massa corpórea, nas relações que são criadas a partir de impactos físicos que alteram o equilíbrio do corpo e a experiência do tempo.

Outro dado importante é a tensão gerada entre as instruções que acompanham os trabalhos e aquilo que acontece nos momentos de interação. As indicações orientam contatos e a produção de relações que estão previstas pelos mecanismos das estruturas. Entretanto, as mais variadas forças gerarão campos imprevisíveis nos quais as escolhas e as habilidades dos participantes ativarão percursos que contam com acasos e resistências que são constadas na experiência.

William Forsythe ${ }^{196}$ fala sobre os objetos coreográficos citados acima como campos de

${ }^{196}$ Em entrevista realizada no dia 25 de março de 2015, em Frankfurt. 
ação nos quais certos comportamentos e condições de movimentação são mais ou menos prováveis. Se em While Bouncy Castle o ambiente tende a gerar saltos e ampliar as possibilidades do corpo em uma relação de menos contato com o chão, em The Fact of Matter, o que acontece é o contrário. O corpo suspenso encontra dificuldades para o seu deslocamento é quase forçado a abandonar as argolas e pisar em chão firme. A sensação da massa e do peso do corpo são também características que se evidenciam nesses trabalhos.

$\mathrm{Na}$ abordagem do trabalho Nowhere and everywhere at the same time, destacarei qualidades de uma paisagem sonora que aciona e mantém o trabalho em movimento. Analisarei, para isso, a versão de 2015, que faz parte da exposição The Fact of Matter. Em seguida, comentarei a versão do trabalho que foi apresentada na Bienal de Veneza, no ano de 2012, e na qual referenciais de orientação e negociação com o entorno são destacados.

O nome do trabalho Nowhere and Everywhere at the Same Time ${ }^{197}$ refere-se a maneira como o Jacques Lusseyran, deficiente visual e ativista político francês, descreve o espaço mental onde ele visualiza formas e ideias. Da mesma forma, essa frase pode ainda se referir à força da gravidade, a esse campo que está presente em todos os lugares e em nenhum lugar ao mesmo tempo, já que estamos em constante relação com ele sem que haja uma relação visual.

William Forsythe fala sobre a proposta do trabalho e sobre os diálogos com a matemática e com a produção de espaços imaginários e físicos:

Quando o matemático cego Bernard Morin perguntou onde que a imagem do processo de inverter uma esfera existia em sua imaginação, ele deu a famosa resposta: "Em nenhuma parte e em todos os lugares ao mesmo tempo." E assim é com o objecto coreográfico: ele é um modelo de transição potencial de um estado para outro, em qualquer espaço que se possa imaginar. (FORSYTHE, tradução nossa) ${ }^{198}$

A versão de estreia do trabalho Nowhere and everywhere at the same time aconteceu em Nova Iorque, em 2005. Vera Liber $^{199}$ descreve o ambiente proposto por Forsythe naquela ocasião:

A música eletrônica ambiente de Thom Willems, com insinuações ocasionais de

\footnotetext{
${ }^{197}$ Informação disponível no link: http://www.williamforsythe.de/installations.html?\&no_cache=1\&detail=1\&uid=21. Acesso em maio de 2015. ${ }_{198}$ Texto original: "When the blind mathematician Bernard Morin was asked where the imaging of the process of inverting a sphere existed in his imagination, he famously replied: "Nowhere and everywhere at the same time." And so it is with the choreographic object: it is a model of potential transition from one state to another in any space imaginable." (William Forsythe) disponível no link: http://synchronousobjects.osu.edu/media/inside.php?p=essay. Acesso em março de 2015.

${ }^{199}$ Texto disponível no link: http://www.britishtheatreguide.info/reviews/nowhereeverywhere-rev. Vera Liber.
} 
sons de órgãos de igreja e vibrações das cordas, cria um clima de meditação para os dançarinos e para o público, que pode se sentar em bancos, em almofadas no chão, ou caminhar ao redor da obra de arte como na galeria, e considerá-la em parte e/ou como um todo. Nowhere and Everywhere at the Same Time (estreou em Nova Iorque em 2005) é uma performance contínua que acontece durante 90 minutos, sem parar, mas que não há nenhuma obrigação de se permanecer - os dançarinos também vêm e vão. (LIBER, 2009, tradução nossa) ${ }^{200}$

Originalmente criado para um dançarino solo e composto por 40 pêndulos dispostos em um prédio abandonado na histórica High Line de Nova Iorque, a instalação tem acontecido continuamente em contextos diversos, como a monumental arquitetura industrial do Turbine Hall da Tate Modern e o cenário histórico fornecido pelo Arsenale da Bienal de Veneza. A versão Nowhere and Everywhere at the Same Time No. 2, que foi apresentada na Ruhrtriennale de 2013, no Museum Folkwang, em Essen, na Alemanha, marca um capítulo inteiramente novo no desenvolvimento deste trabalho coreográfico.

A versão de 2015, que será aqui abordada, é muito parecida com a versão de 2013. Este trabalho preserva e privilegia dois interesses centrais na obra de Forsythe: contraponto e a competência coreográfica inconsciente induzida por situações coreográficas. Mais de 400 pêndulos suspensos são ativados e oferecem ao público um ambiente que é uma espécie de labirinto em constante transformação. Os participantes são livres para trafegar nesta área estatisticamente imprevisível, mas são solicitados a evitar entrar em contato com qualquer um dos pêndulos em movimento. Esta tarefa, que automaticamente aciona e alerta a percepção do visitante, produz uma coreografia viva de múltiplas e complexas estratégias de fuga.

$\mathrm{Na}$ versão de 2015, as propriedades sonoras ganham destaque. Uma partitura sonora é criada e transformada em um mecanismo que aciona e mantém os pêndulos em movimento.

\footnotetext{
200 Texto original: "Thom Willems's ambient electronic music, with occasional insinuations of sonorous church organ sounds and string vibrations, creates a meditative mood for the dancers and the audience, who can sit on benches, on cushions on the floor, or walk around the work of art as in gallery, and consider it in part and/or as a whole."Nowhere and Everywhere at the Same Time (premiered in New York in 2005) is a continuous performance loop that plays for 90 minutes without stop, but there is no obligation to stay - the dancers come and go, too."
} 


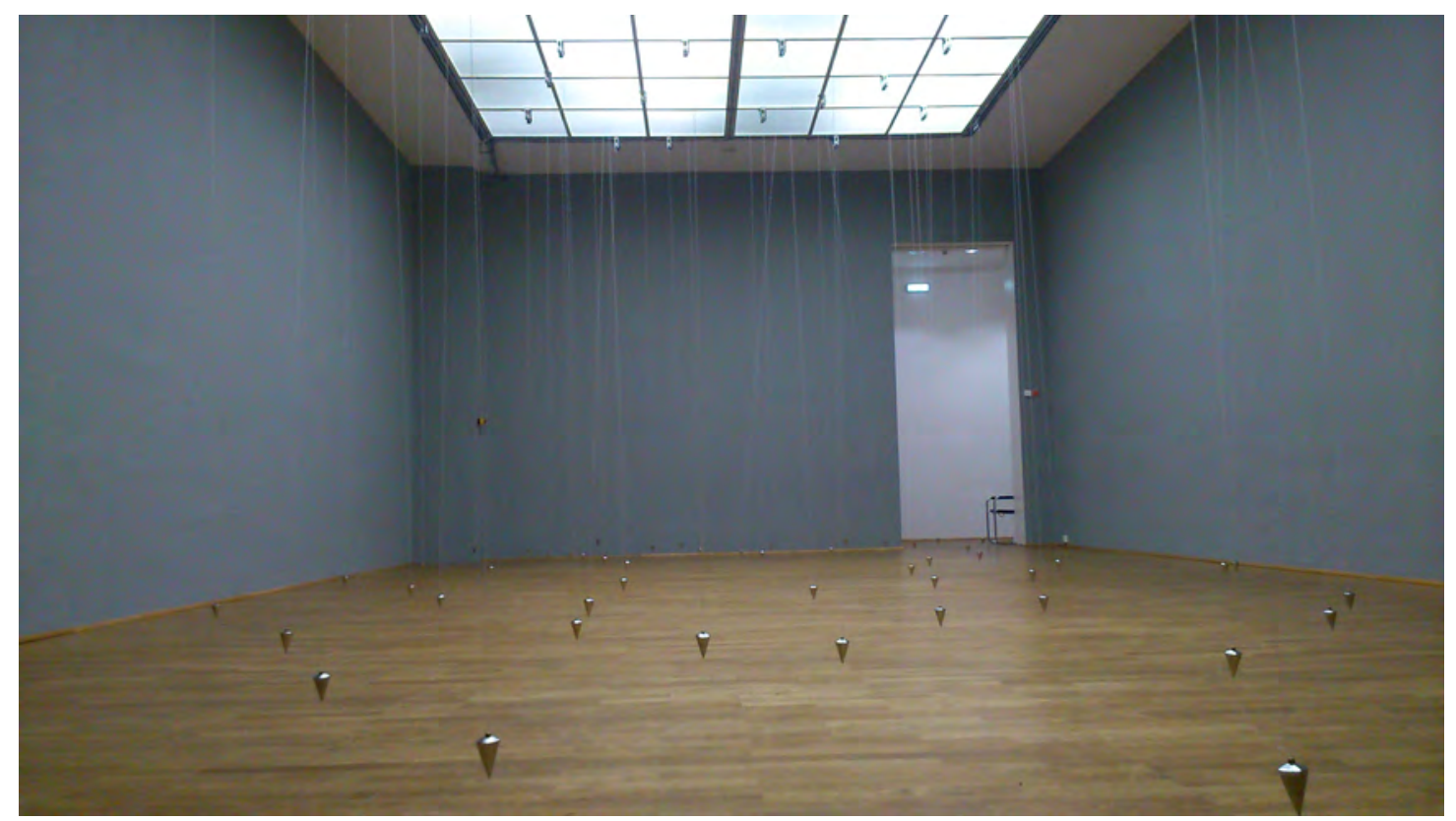

Nowhere and Everywhere at the Same Time, 2015. Arquivo Pessoal

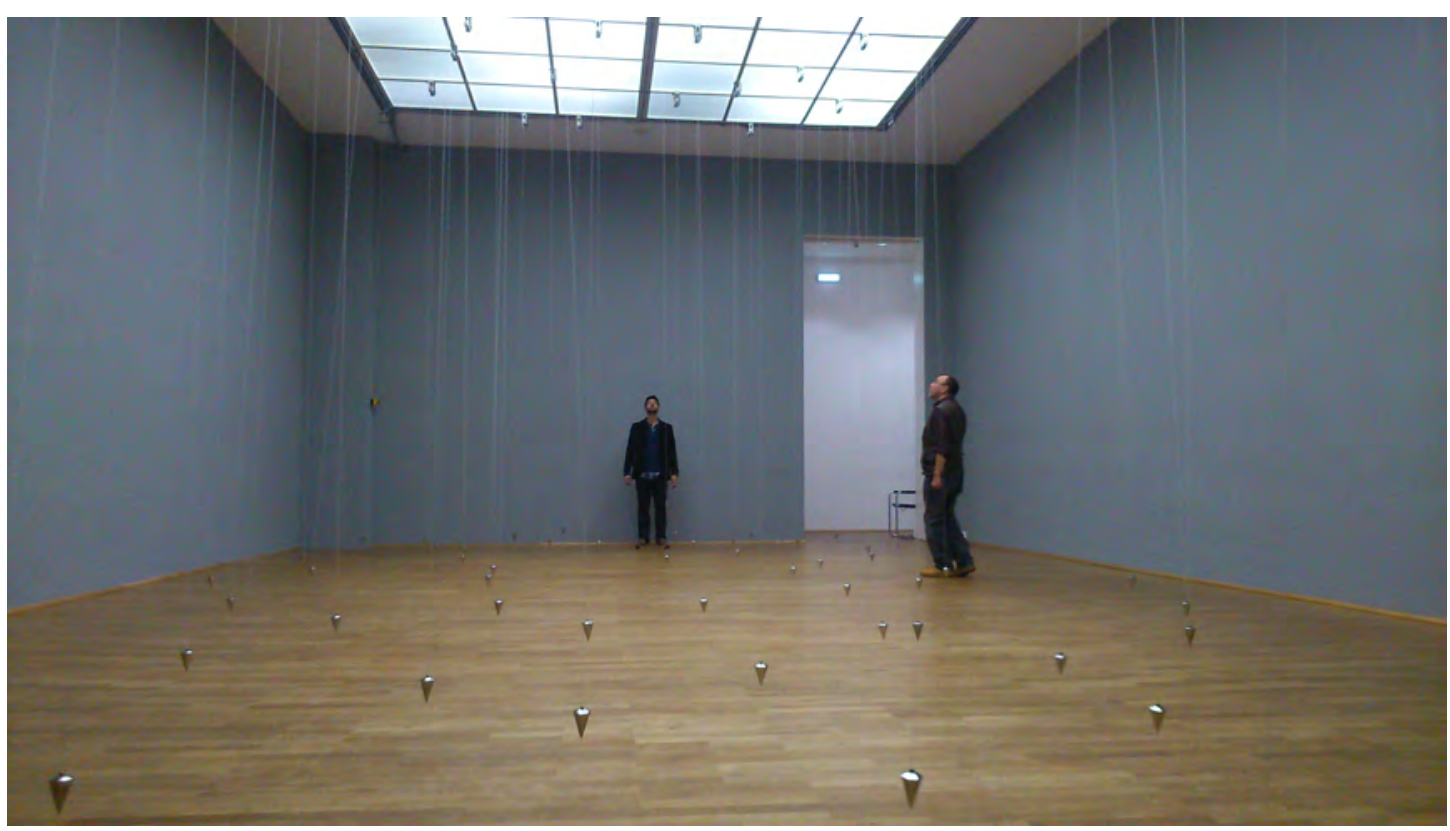

Nowhere and Everywhere at the Same Time, 2015. Arquivo Pessoal 


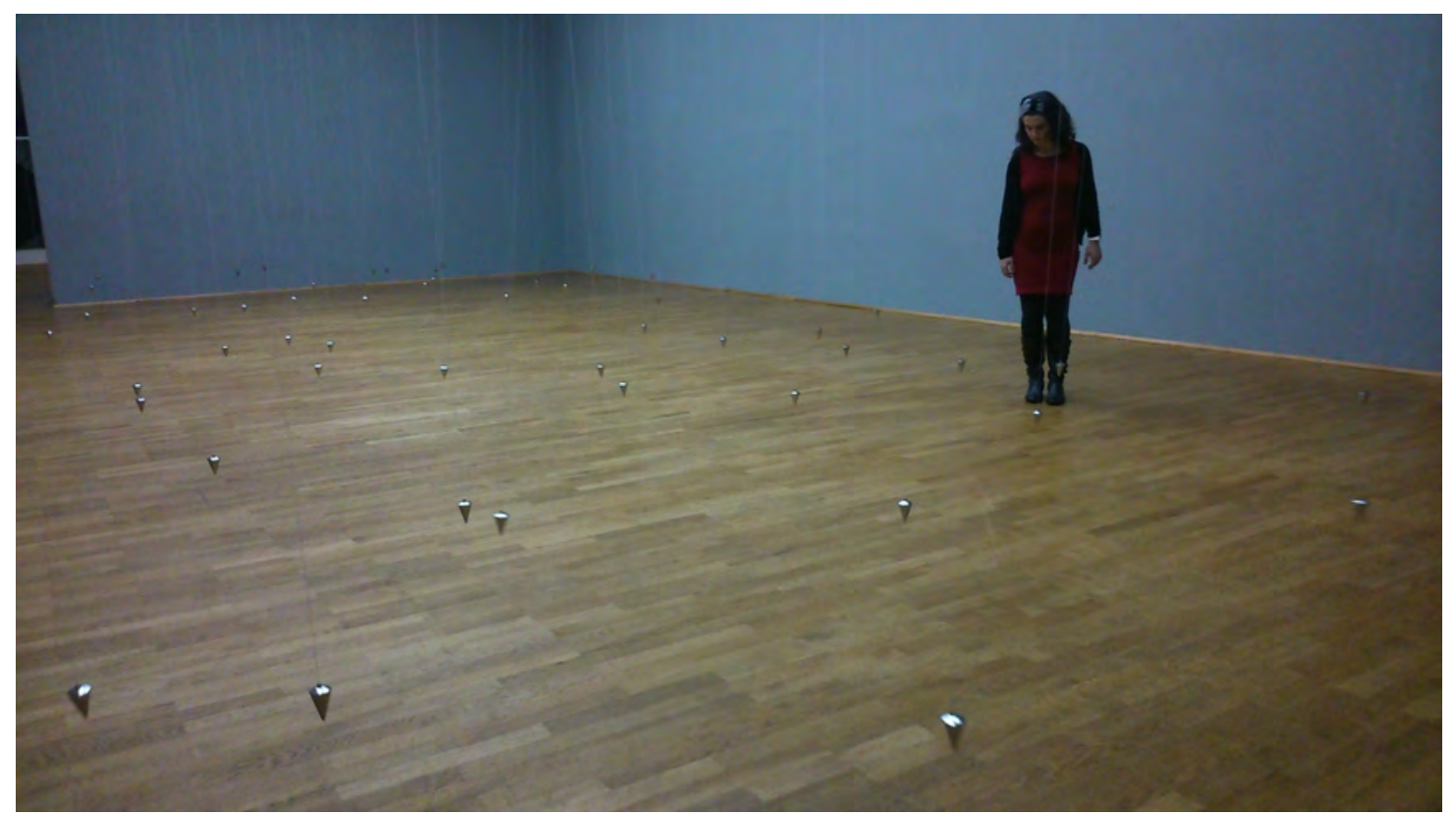

Nowhere and Everywhere at the Same Time, 2015. Arquivo Pessoal

Atravessar o espaço sem tocar os pêndulos é a instrução que aparece logo na entrada da sala. Os pêndulos se deslocam de modo mais ou menos regular até que a interação das pessoas com esses eixos móveis provocam perturbações no ambiente. Os pêndulos se desorientam de seus trajetos e forçam desvios naqueles que estão em seu campo se ação. Um age no outro. Quem está em movimento precisa estar atento aos pêndulos que avançam em diferentes direções. Relações frontais ficam mais complexas à medida que o corpo se move entre um e outro dos pêndulos suspensos. O espaço ganha profundidade, aquilo que acontece em frente, atrás e dos lados faz parte de um conjunto de forças imprevisíveis que direcionam o corpo para caminhos aleatórios. Já não há mais referenciais que estabelecem posições como frente ou atrás. Os estímulos presentes em todos os lados geram um estado de alerta no qual os rodopios acompanham a percepção em varreduras que jogam o corpo para diferentes e simultâneas posições no espaço.

Os desvios são acompanhados de reorientações, mudanças rápidas de perspectiva que dialogam com o som dos mecanismos que acionam os pêndulos. Esses mecanismos, dispostos no teto, na estrutura que fixa e suspende os pêndulos, chamam a atenção. Como funciona esse objeto? Qual a relação do som que ouvimos enquanto nos deslocamentos e o acionamento dos pêndulos. O impulso de investigar o funcionamento do trabalho promove paradas. Alguns participantes se afastam da área de ação dos pêndulos para estudar essa relação do som com os movimentos. Descobertas algumas das leis que ativam o espaço, muitos voltam a interagir com o objeto coreográfico, experimentam ações, reações, esbarram nos pêndulos, nos fios que 
os suspendem e se divertem com os encontros ao acaso com outros corpos enquanto um amplo campo perceptivo é gerado. O ponto de fuga do espaço euclidiano se espalha pela sala e dispara uma sucessão de eventos que reconfiguram constantemente corpo e espaço.

A versão de 2012 que fez parte da Bienal de dança, em Veneza, e que estava mais próxima da primeira versão apresentada em Nova Iorque foi criada inicialmente para o artista Brock Labrez, que é ator, dançarino, cineasta, produtor, diretor e que estudou astrofísica. Forsythe identifica na atuação de Labrez habilidades e características que são fundamentais para essa versão. Labrez e Forsythe ${ }^{201}$ falam sobre o trabalho e sobre a importância de um contato demorado com a proposta nesta temporada em Veneza.

Em Veneza ${ }^{202}$, o trabalho aconteceu no primeiro andar do Rand Hall onde o dançarino Brock Labrez interagiu, por aproximadamente quatro horas, com os cento e cinquênta pêndulos pendurados.

Brock Labrez se move entre pêndulos em uma arquitetura na qual a ação do tempo aparece impressa nas paredes, nos resíduos de tintas e cores, e na própria estrutura que desenha o grande espaço que abriga o trabalho. As interações com o entorno e as respostas imediatas, que são ocasionadas pelos percursos variáveis dos pêndulos, solicitam do artista uma atenção expandida que leva em consideração os diferentes elementos que compõem o espaço. Labrez fala sobre a ação da luz do dia que atravessa a janela e cria uma energia específica a qual ele precisa reagir imediatamente ${ }^{203}$. Essas variações ambientais evidenciam a ativação de uma arquitetura que é gerada no encontro de um espaço imaginário e interior, criado pelo artista, e as variações e vibrações do entorno. Os desenhos espaciais imaginários, os percursos registrados em abstrações que favorecem orientações espaciais e o choque entre essas estruturas imaginárias com as forças e linhas que geram desvios e produzem deslocamentos físicos imprevisíveis ativam e revelam um espaço material e físico formado por condições e durações que se manifestam nos mais variados elementos.

\footnotetext{
${ }^{201}$ Conversa disponível no vídeo: https://www.youtube.com/watch?v=wb9QNghklPk. Acesso em dezembro de 2014.

${ }^{202}$ Informação disponível no site: http://events.cornell.edu/event/nowhere_and_everywhere_at_the_same_time. Acesso em maio de 2015.

${ }^{203}$ Depoimento do artista no vídeo: https://www.youtube.com/watch?v=wb9QNghklPk. Acesso em maio de 2015.
} 


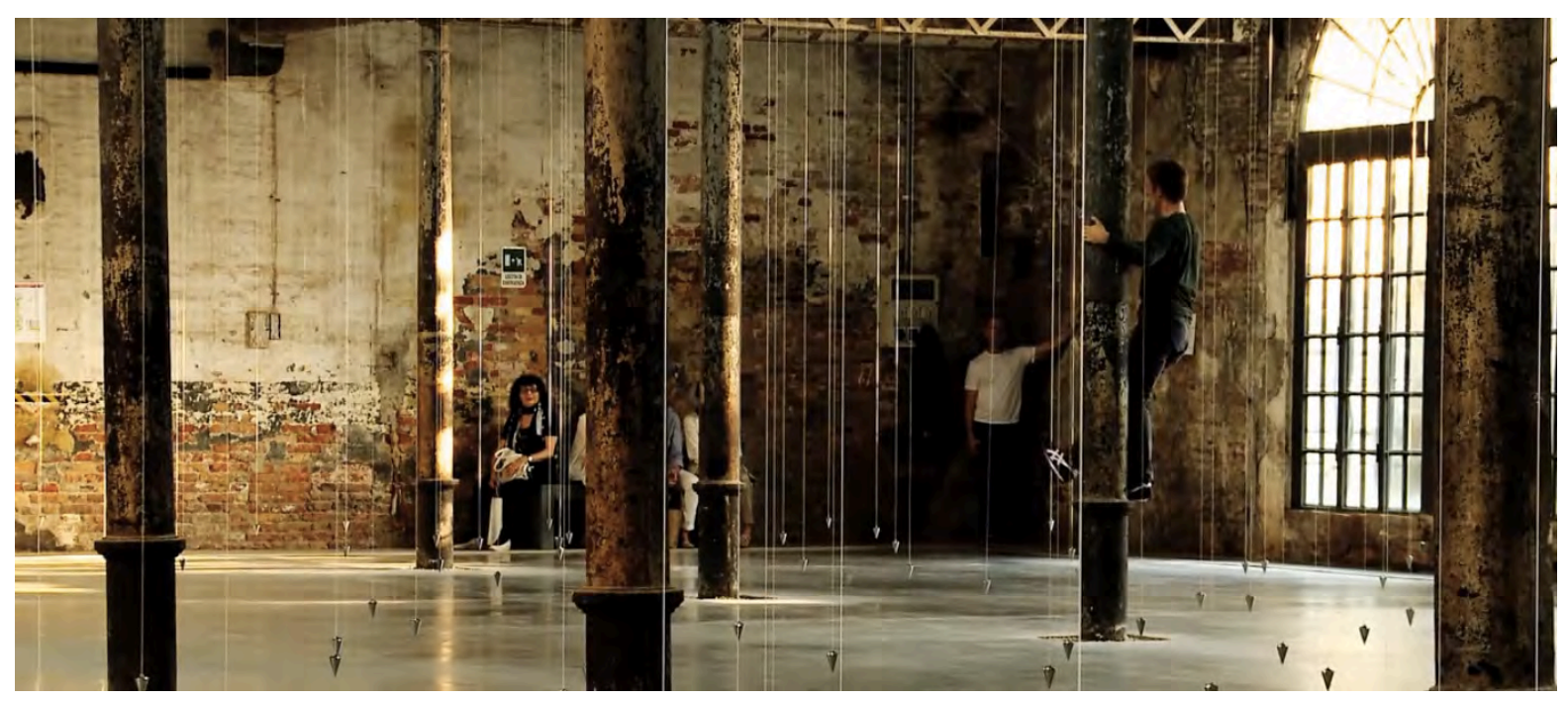

Imagem: do vídeo Bienal de dança de 2012, em Veneza

Esta perspectiva que prevê encontros entre espaços gerados como abstrações e o confronto com elementos e condições físicas pode ser verificada no universo da dança, nas partituras ou esboços espaciais que os dançarinos visualizam e confrontam com as interferências e alterações de percurso. Forsythe propõe um diálogo, uma troca com o ambiente, com as condições e com elementos que modelam uma arquitetura transitória, aberta e formada por estímulos vivos e mutantes. A dança ou a noção coreografia investigada por Forsythe aparece aqui como uma ligação frágil entre pontos dispersos que atravessam o corpo e reorientam as possibilidades espaciais, os pontos de observação e a percepção para os estímulos ambientais.

O trabalho explora potencialidades metafóricas e cinéticas ao confrontar indicações espaciais abstratas e a realização de movimentos no espaço. Os ambientes mentais e físicos se justapõem e produzem novas possibilidades ambientais para o corpo e para os pensamentos. Os lugares acessados pelo corpo partem de orientações que não são acessadas diretamente pela visão, mas por um olhar que se manifesta na tensão entre imagens construídas como orientadoras de deslocamentos e os elementos que geram interferências e alterações ambientais. Os olhos trafegam por lugares invisíveis que cortam o ar e são, ao mesmo tempo, modificados por informações que saltam de diferentes elementos que constituem o entorno.

Essa negociação com o ambiente aparece em relações móveis que evidenciam variações arquitetônicas. Qualidades e diferenças podem ser observadas nas interferências entre linhas, formas e ângulos que reposicionam o olhar e os pontos de vista da arquitetura, por exemplo. O espaço é também aquilo que se ouve, as passagens que provocam movimento, como rampas, corredores, escadas e a intromissão do corpo nessas espacialidades. A noção de 
arquitetura é apresentada aqui como reescritura de dinâmicas corporais e espaciais compostas por camadas visíveis, invisíveis, abstratas, materiais, subjetivas e objetivas.

Nowhere and everywhere at the same time, em nenhum lugar e em todos os lugares ao mesmo tempo, dialoga com essa ideia de sobreposição de lugares que são representações mentais com a produção de espaços que aparecem a partir de interações entre estímulos físicos e ambientais. O trabalho que foi inspirado, inicialmente, por reflexões apresentadas pelo matemático Bernard Morin coloca em questão a investigação de sistemas de representação como potenciais de transição. Esses sistemas imaginários são como notas ou partituras que orientam o surgimento de movimentos que podem ser investigados a partir de diferentes ações em variados contextos. Essa relação entre estruturas abstratas e o modo como elas se manifestam no espaço prevêem desdobramentos dos eventos em múltiplas direções, já que a tradução de partituras conta com aspectos fenomenológicos que indicam alterações nas indicações previamente traçadas. William Forsythe ${ }^{204}$ comenta essa relação:

Eu faço este comentário em relação ao Morin para introduzir as múltiplas possibilidades da nossa prática. Morin viu um evento no espaço de sua mente que ele traduziu em esculturas e, posteriormente, para a língua universal, ainda um tanto hermética, da matemática. Seu corpo substancial, colocado em ação pela força de seu próprio pensamento deixou uma marca bem perceptível deste conceito no mundo real; de nenhum lugar para algum lugar, não em todos os lugares, e não mais exclusivamente dentro de seu corpo. (FORSYTHE) $)^{205}$

Essa noção entre aquilo que é traçado de antemão e os percursos que o corpo experimenta se refere à abordagem coreográfica proposta por Forsythe. Seus trabalhos são fundamentados em referenciais estáveis, em abstrações, teorias e equações que organizam o espaço de tal modo que uma partitura ou um campo de probabilidades se desdobra em orientações que serão experimentas pelos corpos e pela imaginação de diferentes maneiras. A estrutura que convida à ação é transpor à medida que o corpo se relaciona.

\footnotetext{
${ }^{204}$ Relato disponível no link: http://synchronousobjects.osu.edu/media/inside.php?p=essay. Acesso em janeiro de 2015.

${ }^{205}$ Texto original: "I make this comment in relationship to Morin to introduce the manifold possibility of our practice. Morin saw an event in the space of his mind that he then translated with haptic skill into sculptures and subsequently into the universal yet somewhat hermetic language of mathematics. His quite substantial body, put into action by the force of his idea left a very discernible trace of this idea in the real world; from nowhere to somewhere, not everywhere, and no longer exclusively within his body.” (William Forsythe). Texto disponível no link: http://www.williamforsythe.de/essay.html. Acesso em abril de 2015.
} 


\section{Objetos oscilatórios}

Os Objetos Coreográficos tendem a lançam o espectador a uma espécie de vertigem. A ação da gravidade, os mecanismos envolvidos nas propostas e as experiências físicas geram campos nos quais a atenção e sensação de imprevisibilidade mantém o corpo ativo e os sentidos em estado de alerta.

Essas condições ambientais, atmosféricas e espaciais implicam na instauração de uma perspectiva processual, o que coincide com propósitos e premissas apresentados pela arte contemporânea. Os movimentos começam em qualquer lugar, começam antes de se apresentarem aos olhos e continuam em ressonâncias que atravessam os limites da visão. Movimentos são eminência, lugares à espera, traços que confundem mental e físico, campos que se justapõem. Flutuar, sobrevoar, deslocar, afastar-se dos pontos de referência estáveis e seguros. Como me desloco e me permito conhecer o mundo sob outros pontos de vista? Como cruzar e produzir espaços que levam em consideração o cheiro, a textura, o som, o silêncio e a sensação do ar sobre a pele? Essa perspectiva fenomenológica se aproxima de qualidades e características bastante investigadas pelas artes e pelo teatro contemporâneo.

Conforme referenciais abordados no início desta seção, as práticas e investidas do Minimalismo e a abertura dos conceitos de objeto e coreografia favoreceram importantes investigações sobre a matéria. As propriedades físicas e materiais incentivam a construção de processos perceptivos que determinarão importantes mudanças conceituais e práticas nas produções de arte.

Se os Objetos Coreográficos indicam caminhos ou estimulam possibilidades de deslocamento, os trajetos percorridos dependem de decisões, descobertas e relações que o participante é capaz de estabelecer com os trabalhos. Eles são dispositivos desenham no espaço forças e linhas que convidam ao movimento, que desarticulam esquemas já dados. Os Objetos Coreográficos não determinam o percurso mas antes disponibilizam o acaso, o inesperado e a desestabilização de ordens na produção de novos espaços.

O espaço sob o ponto de vista da Heterotopia, de Michael Foucault, e das considerações de Henri Lefebvre aparece nos trabalhos analisados como um entrelaçamento de ações, vestígios e camadas visíveis e invisíveis que se articulam, se somam e se subtraem em fórmulas em aberto que são acessadas de modo muito particular por cada participante. Existem linhas gerais que orientam e criam zonas nas quais algumas relações serão mais prováveis do que outras. Entretanto, a imprevisibilidade das experiências reside na 
singularidade dos aparelhos e processos perceptivos de cada corpo. Os trabalhos são propostas abertas, são linhas que serão modificadas pela interação do visitante ou do espectador para a construção de paisagens heterogêneas.

A movimentação do espaço move o corpo da mesma forma que a agitação do corpo provoca alterações na atmosfera. Lefebvre (1991) diz: "A lei do espaço reside dentro do próprio espaço, e não pode ser resolvida em um relacionamento aparentemente claro de uma relação dentro-versus-fora, que é apenas uma representação do espaço." ${ }^{206}$ Neste ponto, o autor ressalta ainda as linhas que entrelaçam corpo e espaço.

Lefebvre (1991) cita o exemplo de uma aranha que tece a sua teia. Qualidades como equilíbrio, organização e adaptabilidade constituem um sistema no qual corpo e espaço estão implicados e são produzidos simultaneamente. O pensamento ganha forma, visibilidade e é manifestação da ação física que produz a teia. É claro que o modo como produzimos pensamentos difere do modo como os pensamentos são produzidos pelas aranhas. Entretanto, existem princípios, neste exemplo, que colocam o corpo em uma relação tão íntima e vinculada ao espaço que passamos a supor que o nosso corpo, como todos os demais corpos fazem parte também de uma trama, de um sistema relacional no qual abstrações, fisicalidades e materialidades se justapõem na formação de espaços que reverberam e ecoam os mais diversos pensamentos.

A partir daí percebemos que o corpo não ocupa um espaço porque "nós sabemos que o espaço não é um vazio pré-existente dotado de propriedades formais independentes" 207 . Essa inseparabilidade que entrecruza corpo e espaço, é assim observada por Lefebvre:

Na natureza, seja orgânica ou inorgânica, simetrias (em um plano ou através de um eixo) existem onde quer que haja dualidade ou bilateralidade, direita e esquerda, "reflexo" ou rotação (no espaço); estas simetrias, no entanto, não são propriedades externas dos corpos. Embora definíveis em termos "puramente" matemáticos como aplicações, operações, transformações ou funções - elas não são impostas sobre os corpos materiais, como muitos filósofos "rejeitaram" em pensamentos anteriores. A mobilização de energia dos corpos - produz espaço e produz o próprio corpo juntamente com seus movimentos, de acordo com as leis do espaço. (LEFEBVRE, 1991:171, tradução nossa) ${ }^{208}$

\footnotetext{
${ }^{206}$ Texto original: "The law of space resides within space itself, and cannot be resolved into a deceptively clear inside-versus-outside relationship, which is merely a representation of the space." (Levrebve, 1991)

207 Texto original: "we know that space is not a pre-existing void, endowed with formal properties alone" (Lefrebvre, 1991: 170)

${ }^{208}$ Texto original: "In nature, wheter organic or inorganic, symmetries (in a plane or about an axis) exist wherever there is bilaterality or duality, left and right, 'reflection', or rotation (in space); these symmetries are not properties external to bodies, however. Though definable in 'purely' mathematical terms - as applications, operations, transformations or functions - they are not imposed upon material bodies, as many philosophers opposed, by prior thought. Bodies- deployments of energy - produces space and produce themselves, along with their motions, according to the laws of space." (Lefrebvre, 1991:171)
} 
Essas afinidades e reciprocidades entre corpo e espaço são amplamente investigadas por Forsythe em sua produção. Os corpos investigam leis e qualidades espaciais ao mesmo tempo em que buscam recursos e estímulos para a ampliação das possibilidades do movimento. Os caminhos conhecidos e aqueles que surgem aleatoriamente fazem parte de estratégias de estudo que levam em consideração notações, linhas, pontos, curvas e imprevisibilidades. Os traços mapeados e previstos por metodologias ou técnicas objetivas para a produção de movimentos são o ponta pé inicial em um processo no qual a orientação e a desorientação acontecem simultaneamente. O espaço agirá sobre os corpos do mesmo modo que o corpo agirá sobre o espaço. Forças e dinâmicas acionarão desenhos já conhecidos sob condições menos rígidas, mais precárias e frágeis nas quais leves sopros deixarão a mostra camadas que estavam escondidas.

Desenhar o corpo, a partir de uma perspectiva euclidiana, implica colocar o corpo em um espaço vazio e nesse lugar deslocá-lo de um ponto ao outro de tal modo que se possa medir, calcular e simplificar o deslocamento em um sistema fechado que poderá ser posteriormente reproduzido de uma mesma maneira por diferentes corpos.

Entretanto, é possível desenhar esse mesmo corpo em deslocamento a partir de uma perspectiva espacial que prevê uma dinâmica de interação entre os múltiplos elementos que se relacionam com esse corpo. E esse corpo, que não é em si, mas em relação, apresenta-se aqui como um processo que absorve e é absorvido pelo entorno, pelas interferências, pelos sons, pelas cores, temperaturas e texturas.

E é sob essa perspectiva que trata das negociações, vínculos e relações que acionam corpo e espaço, que os Objetos Coreográficos, de William Forsythe, podem ser observados sob o ponto de vista da suspensão. Suspender aparece aqui como ação ou qualidade na qual se manifesta a indeterminação, o estado provisório, a fragilidade, a alteração de pontos de observação e a oscilação. Os ambientes suspensos indicam, desde modo, lugares de desvio, situações instalativas que dizem respeito também às formações teatrais contemporâneas.

Se dança, teatro, artes plásticas ou coreografia, o que importa nas propostas de Forsythe é a ativação de vetores para a percepção, a produção de alterações que agem diretamente no corpo e na sensibilidade dos envolvidos em seus procedimentos. Argolas, pêndulos, balões, arquiteturas, massas de ar, suspensões físicas do corpo, desvios, saltos, curvas, deslizes, quedas e paragens são alguns dos elementos e das condições que geram texturas e desestabilizam padrões de movimentação.

O desdobramento de sua produção em uma ampla variedade de propostas e a extensão de sua zona de ação para além de lugares e campos conhecidos ou mesmo instituídos provoca 
uma desorientação que se manifesta em giros, em instantes de desequilíbrio e em flutuações que geram novas conexões entre os pés e o chão, entre o corpo e o entorno. A observação de forças que interagem entre si nos Objetos Coreográficos acima analisados confirma o caráter processual e físico que está implicado no acontecimento desses eventos.

Marcel Duchamp, Minimalismo, artes visuais, filosofia, física, dança, prática, teoria e os mais variados referenciais influenciaram aberturas nos procedimentos de Forsythe ao mesmo tempo em que atualizam e evidenciam, ainda hoje em suas práticas, importantes prerrogativas que foram assunto e tema das vanguardas do século $\mathrm{XX}$ e que ocupam, atualmente, lugar de destaque na produção de arte contemporânea.

Entre as inúmeras contribuições das vanguardas artísticas que continuam a despertar o interesse de artistas, teóricos, pesquisadores e artistas-teóricos-pesquisadores está a observação de conceitos sob um ponto de vista dinâmico e mutável que faz os olhos e os sentidos reconhecerem e se confrontarem com instabilidades e tremores que abalam não só o olhar, como o corpo e a composição de paisagens. Objeto, sujeito e espaço se movem, geram intensidades, são manifestações físicas e temporais fugazes que não se limitam a um único ponto de vista, a um único conceito ou às bordas de um único suporte. Esse terreno dilatado no qual se cruzam expressões, forças, formas e potências é muitas vezes estudado a partir de noções como performance, performatividade, teatralidade, entre outras. Independentemente do nome dado, da abordagem ou dos conceitos operacionais, o que está em jogo nesses processos de produção parece ser a criação de zonas de indiscernibilidade provocadas por deslocamentos de perspectiva e abalos na sensibilidade.

Embora existam diferentes possibilidades de abordar noções como teatralidade e performatividade, esses conceitos aparecem aqui como pano de fundo de uma discussão que prevê o movimento e a construção de paisagens oscilatórias, móveis e frágeis que são produzidas e desaparecem na reorganização dos sentidos. A linha argumentativa desta pesquisa coloca o teatro, a condição teatral como dinâmica de produção de modos de gerar relações. A teatralidade e a performatividade estão aqui vinculadas a uma possibilidade de experiência estética, de alteração de pontos de vista acostumados, a uma suspensão das regras e parâmetros que se impõem ao olhar.

A transitoriedade e a efemeridade dos eventos e das experiências é ressaltada em detrimento das normas, da estabilização em suportes que garantem proteções e evitam a passagem e a interferência do tempo. O terreno se alastra e sobrepõe lugares e funções, obra e espectador compartilham espaços e agora produzem pensamentos juntos.

As categorizações, os isolamentos e a dependência dos eventos artístico de suportes 
específicos serão fortemente questionados em ações que, de algum modo, libertarão a produção de arte de exigências que marcaram seu processo de institucionalização. Muito embora essa "libertação" seja posteriormente assimilada e institucionalizada em práticas, muitas vezes, previsíveis e padronizadas. Ainda assim, as vanguardas incentivam o pensamento sobre os eventos artísticos para além daquelas categorias que foram criadas como modo de deter e controlar a história e os processos humanos e existenciais.

A análise dos Objetos Coreográficos, sob o ponto de vista da transitoriedade, de mobilidades espaciais e de problemáticas decorrentes dessas noções auxiliam na observação do fenômeno teatral contemporâneo. Práticas e pensamentos que extrapolam os limites da cena localizam o teatro em um terreno flexível, movediço e indeterminado no qual informações vindas das artes visuais, da dança e da filosofia, por exemplo, reconfiguram constantemente a sua dinâmica.

A observação desses movimentos, previstos em situações e condições instalativas que assumem o espaço como uma instância movediça e aderente, auxilia na observação do teatro contemporâneo sob um ponto de vista transitivo e experimental. Essas condições, presente nas propostas de Forsythe, principalmente no contexto dos Objetos Coreográficos, justificam a apresentação de práticas e procedimentos propostos por Hélio Oiticica e Lygia Clark na seção anterior.

Há um senso comum que localiza e associa o teatro aos limites do palco, da representação e de textos dramáticos. Quando surge o termo teatro, teatral ou mesmo espetáculo, ocorre, na maioria das vezes, uma associação quase automática desses termos à ideia de representação, de cópia. Entretanto, o que proponho aqui é um olhar curioso sobre os desdobramentos da ação e da noção de teatro.

Para pensar o ambiente teatral contemporâneo apresentei considerações sobre arquitetura, objeto, coreografia e condições instalativas que coincidem com a multiplicação de linhas de fuga que confundem referenciais padronizados e promovem o surgimento de abordagens mais dinâmicas para o teatro.

\section{Teatralidades contemporâneas}

Como e a partir de quais referenciais é possível pensar o teatro contemporâneo?

O termo teatral já foi utilizado em importantes análises teóricas e críticas como condição negativa ao propor relações estanques entre obra e espectador. O teatral seria aquilo 
que tende a absorver o espectador, aquilo surge como forte presença que dificulta reflexões e observações mais criteriosas do evento. O teatral seria aquilo que absorve os sentidos e dificulta a capacidade de análise.

Essa perspectiva negativa, apresentada pelo autor Michael Fried no texto Art and Objecthood, na década de 60, apresenta e aponta a noção de teatral como negação da arte, o que, de algum modo, coincide com a noção de teatralidade como condição mimética vinculada ao simulacro e à imitação. O conceito de teatralidade como condição negativa e até mesmo pejorativa foi uma das principais discussão propostas pelo crítico Michael Fried. Vale a pena citar, no entretanto, que outros críticos compartilharam desta mesma ideia, como é o caso de Clement Greemberg ${ }^{209}$. Nas palavras de Michael Fried (2002):

\begin{abstract}
A sensibilidade literalista é teatral porque, para começar, está interessada nas circunstâncias factuais em que se dá o encontro do observador com o trabalho literalista. Morris deixa isso claro. Enquanto na arte que a precede "o que é para ser experimentado do trabalho encontra-se estritamente em seu interior", a experiência da arte literalista é a de um objeto em uma situação - que, virtualmente por definição, inclui o observador. (FRIED, 2002:134) $)^{210}$
\end{abstract}

Essas considerações de Fried foram fundamentadas em suas análises sobre os vínculos e relações entre obra e espectador colocadas pelos minimalistas. Fried vê nas propostas do Minimalismo uma relação análoga aos pactos que acontecem no teatro, quando uma forte presença de palco é capaz de absorver o espectador para um espaço regido por leis e lógicas particulares. Essa imersão se assemelha, de acordo com o crítico, ao caráter literal exposto por pressupostos minimalistas. Para Fried, o realce e a afirmação de aspectos materiais, previstos pela literalidade, na qual fábulas e enredos são ignorados, faz com que a matéria se imponha de tão modo que o espectador acaba sendo absorvido por essa presença que possui leis e regras próprias. O teatral é apresentado, neste contexto, como uma "presença de absorção ou absortiva" que joga o espectador para dentro de uma tela, de uma área com bordas delimitadas. Essa condição impactante, de acordo com Fried, impede a apreciação dos trabalhos como formações autônomas que merecem ser observadas sob pontos de vista mais analíticos e criteriosos.

Essas questões foram amplamente discutidas e, no contexto atual, é possível afirmar que a observação de Michael Fried sobre o teatral ou a teatralidade pode ser observada ainda sob

\footnotetext{
${ }^{209}$ A presença da arte literalista, a qual Clement Greemberg foi o primeiro a analizar, é basicamente um efeito ou qualidade teatral, um tipo de presença de palco.

${ }^{210}$ Texto original "Art and Objecthood", de Michael Fried, traduzido como "Arte e objetividade" e publicado na Revista do Programa de Pós-Graduação em Artes Visuais - EBA - UFRJ - 2002. Tradução Milton Machado.
} 
um ponto de vista positivo e até mesmo coerente quando colocamos a noção de teatral em um lugar de construção de relações e dinâmicas que se articulam entre conceitos como obra e espectador.

A noção de teatro ou de teatralidade ganham conotações mais abrangentes e indeterminadas no contexto da arte contemporânea. O teatral está hoje amparado em condições - como colisões, desvios, oscilações e dispersões - que podem ser observadas em diferentes contextos da produção de arte contemporânea. Michael Fried, mesmo sem querer, antecede discussões pertinentes no que diz respeito à produção teatral e ao surgimento de pensamentos que favorecerão o deslocamento das noções de teatral, de teatralidade e de performatividade por diferentes práticas e procedimentos que se comprometem com o acionamento de dinâmicas e de campos perceptivos.

É possível dizer ainda que à medida que a presença do espectador se torna fundamental no contexto do acontecimento artístico uma "condição teatral" parece surgir como uma das principais bases de criação em diferentes procedimentos e produções de arte.

Nesta "condição teatral" tempo e espaço ultrapassam categorias, borram as definições que enclausuram o tempo em fábulas que se dão em situações paralelas e estabelecidas por lógicas fundamentadas em modelos específicos de pensamento. A apresentação de um recorte, de um ponto de vista ou de fragmentos se sobrepõe à possibilidade de uma experiência complexa e fenomenológica.

A observação de aspectos físicos e de texturas que se ligam nas produções cênicas chamam a atenção para a produção de espacialidades que coincidem com qualidades previstas por noções como performatividade e teatralidade.

O termo teatralidade, assim como a noção de performatividade, se refere às dinâmicas, aos modos de fazer e ver sob uma perspectiva que considera o acaso, as qualidades ambientais e as oscilações da forma. Esses termos se comunicam e trocam qualidades que dificultam, muitas vezes, uma separação. Se a performatividade diz respeito a um fazer ativo, dinâmico, aberto às interferências do entorno, a uma ação ambiental, a teatralidade discute e põe em prática modos de ver, de se relacionar. Levando-se em consideração que olhar é aquilo que acontece no corpo e que provoca alterações na matéria, a performatividade e a teatralidade são noções que se entrelaçam e se misturam em propostas e procedimentos da arte contemporânea que dão ênfase ao movimento e à ativação de campos perceptivos. Como faço? E como vejo? São algumas das perguntas que dão início a um longo processo de investigação prático e teórico sobre a arte no contexto atual. É importante frisar ainda a impossibilidade de qualquer 
definição estável e absoluta para essas noções, já que elas se desdobram em múltiplas análises e abordagens em diferentes circunstâncias e contextos.

O autor e pesquisador Luiz Fernando Ramos aborda a noção de espetáculo como conceito que articula elementos e expande a possibilidade de análise do fenômeno teatral contemporâneo. A noção de espetáculo diz respeito à produção de arte sob um ponto de vista expandido que é assim analisado pelo autor: "Para além da crise da representação o espetáculo sobrevive, expandido para todas as formas de manifestação artística. (Ramos, 2009)." 211 O conceito de espetáculo ou espetacular dialoga com as perspectivas sugeridas pelos termos performatividade e teatralidade, de acordo com a abordagem aqui apresentada, e auxilia a observação do fenômeno teatral sob uma perspectiva que leva em consideração aspectos táteis, visuais e potencialidades imagéticas ${ }^{212}$ assim comentadas por Ramos:

\begin{abstract}
Uma reflexão contemporânea sobre o fenômeno teatral, além de transpor os limites territoriais convencionados ao teatro e pensar a teatralidade para além desses confins, como atravessando a vida humana de uma maneira geral, terá de partir desse aspecto essencialmente visual e táctil das artes cênicas. Muito mais do que nas histórias e narrativas, muito além do que nos universos psíquicos e oníricos dos personagens, é na matéria bruta e visível oferecida aos olhos e ao tacto que se configuram os discursos e que se afirma a condição histórica dos fenômenos espetaculares. (RAMOS, 2009) $)^{213}$
\end{abstract}

Silvia Fernandes ${ }^{214}$, ao analisar teatralidades plurais que se apresentaram no festival de Avignon, na França, discorre sobre a dissociação do termo teatralidade de qualidades abstratas que associam o fenômeno teatral a conceitos vagos e genéricos. Uma das noções que a autora logo problematiza é aquela sugerida por Roland Barths ao descrever a teatralidade na seguinte fórmula: teatro menos texto. $\mathrm{O}$ que a autora propõe é uma abordagem migratória para o termo teatralidade e a observação da sua presença ou manifestação a "partir do uso pragmático de certos procedimentos cênicos e, especialmente, da materialidade espacial, visual, textual e expressiva de escrituras espetaculares específicas". (Fernandes, 2009) A teatralidade estaria, sob esse ponto de vista, associada a produção de mudanças, de escalas, de modos de se relacionar e tencionar o real. $\mathrm{O}$ teatral como a produção de espacialidades que

\footnotetext{
${ }^{211}$ No texto "Por uma teoria contemporânea do espetáculo". Disponível no link: http://www.portalabrace.org/vcongresso/textos/territorios/Luiz\%20Fernando\%20Ramos\%20\%20Por\%20uma\%20Teoria\%20contemporanea\%20do\%20Espetaculo.pdf. Acesso em novembro de 2015.

${ }^{212}$ Termo utilizado pelo autor no texto citado.

${ }^{213}$ Idem 209.

${ }^{214}$ Silvia Fernandes: "Teatralidade e textualidade. A relacão entre cena e texto em algumas experiências de teatro brasileiro contemporaneo." Texto disponível no link: http://www.raf.ifac.ufop.br/pdf-n7/Pag_167.pdf. Acesso em abril de 2015.
} 
rompem estruturações já conhecidas, que alteram pontos de vista e não como lugar de absorção, como queria Michael Fried.

O teatro, sob este viés, surge sob a condição de um espaço cambiante, de movimento. E de acordo com as considerações de Gilles Deleuze:

\begin{abstract}
Ora, o que está em questão em toda a sua obra é o movimento. O que eles criticam em Hegel é a permanência no falso movimento, no movimento lógico abstrato, isto é, na "mediação"." (...) Não lhes basta, pois, propor uma nova representação do movimento; a representação já é mediação. Ao contrário, trata-se de produzir, na obra, um movimento capaz de comover o espírito fora de toda representação; tratase de fazer do próprio movimento uma obra, sem interposição; (...) de inventar vibrações, rotações, giros, gravitações, danças ou saltos que atinjam diretamente o espírito. Esta é uma ideia de homem de teatro, uma ideia de encenador - avançado para seu tempo. É nesse sentido que alguma coisa de completamente nova começa com Kierkegaard e Nietzsche. Eles já não refletem sobre o teatro à maneira hegeliana. Nem mesmo fazem um teatro filosófico. Eles inventam na Filosofia, um incrível equivalente do teatro, fundando, desta maneira, um teatro do futuro e, ao mesmo tempo, uma nova Filosofia. (DELEUZE, 2006:29)
\end{abstract}

O teatral, aqui investigado em sua extensão ou saturação, como ambiente ou movimento de interação presente em diferentes práticas, surge como experiência que aparece em diferentes situações e propostas artísticas.

A ampliação de definições relativas ao teatro coincide, por exemplo, com colocações de Jorge Dubatti (2012) ${ }^{215}$ sobre o teatro como fenômeno que não se limita ao reducionismo de definições semióticas que o limita, muitas vezes, a um conjunto de práticas discursivas. O teatro, de acordo com o autor, não se reduz à função expressiva de um sujeito emissor, mas antes implica a doação, a companhia e o compartilhamento.

Jorge Dubatti, ao propor uma Filosofia do Teatro, traz à tona a necessidade de se questionar e superar definições de teatro presentes em dicionários e manuais de estudos teatrais. Busca-se, na Filosofia do Teatro, ampliar definições recorrentes e oferecer uma abordagem mais complexa tanto de um ponto de vista mais pragmático quanto de uma perspectiva mais abstrata que trate da experiência teatral.

\title{
Os Objetos Coreográficos em experiências teatrais
}

No âmbito deste trabalho, é possível perceber a manifestação da teatralidade, da performatividade e de noções que tratam do movimento no contexto da produção de Forsythe e sobretudo nos pontos e procedimentos nos quais condições instalativas e desdobramentos

\footnotetext{
${ }^{215}$ Em “Arte e ciência: Abismo de rosas”. São Paulo: ABRACE, 2012. Luiz Fernando Ramos (Org.)
} 
espaciais são mais evidentes. Nas propostas de William Forsythe, e mais especificamente nos Objetos Coreográficos, o corpo humano e os materiais se afirmam como agentes em uma negociação contínua que prevê deformações em todo o sistema.

Os Objetos Coreográficos favorecem reflexões sobre a noção de teatralidade e sobre o teatral como esse lugar de produção de heterotopias, acontecimentos e situações que solicitam a construção e a descoberta de relações, vínculos e trajetórias - um ambiente que não se subordina a modelos que determinam ou definem o que é teatro.

Essa perspectiva espacial permite observar o evento cênico sob um ponto de vista cinético e multidimensional a partir de referenciais que extrapolam os aspectos literários, textuais e estruturais pautados no surgimento de uma fábula. Podemos observar o evento sob um ponto de vista dinâmico e performativo no qual os mais variados elementos interagem entre si na produção de espaço e ambientes que se alteram constantemente. Materialidades são acessadas e novas orientações para os olhos e para o corpo assumem a importância do espectador, do entorno, de objetos, de linhas que cruzam a cena, de sonoridades que reverberam no ambiente cênico e dos diversos elementos que se encontram, negociam entre si e provocam alterações na matéria, na forma e nos caminhos traçados previamente.

Essa pesquisa pretende, deste modo, estimular diferentes possibilidades de olhar sobre o teatro, sobre o fenômeno teatral a partir das considerações apresentadas sobre a produção de espacialidades. As práticas experimentais de Hélio Oiticica e Lygia Clark, no contexto do Neoconcretismo, contribuem com reflexões sobre o espaço sob uma perspectiva que rompe com esquemas de representação ao mesmo tempo em que aborda temporalidades e um contato imediato e fenomenológico com materialidades que ficavam antes aprisionadas em esquemas e estruturas bidimensionais. O cor, a tinta, as linhas, os pontos, as formas geométricas, o manuseio e ação disparada por objetos e experiências no espaço produzem gestos nos quais a matéria é revelada e relações temporárias são construídas. A observação e prática do fenômeno artístico passa a coincidir com a surpresa do olhar e com a criação de novas ligações com o entorno.

A perspectiva espacial investigada nos trabalhos Objetos Coreográficos analisados coincide com um mapeamento de experiências e transformações do plano, da tela para o espaço "real” ou espaço construído na presença, na relação do corpo com o entorno. Esta perspectiva, presente em concepções e práticas cênicas, pode ser observada em procedimentos de abertura da cena e na explosão do espaço fechado da representação, que expõe o fenômeno artístico como força e potência de interação. O acontecimento teatral é apresentado, assim, 
como paisagem sinestésica que é atravessada e gerada pelo corpo, pelas sensações e pelos sentidos do espectador. Um lugar de passagem no qual o espectador aparece como testemunho ativo de dinâmicas e proposições que o convidam ao trânsito, ao deslocamento de pontos de vista, de referenciais físicos, sensoriais e intelectuais. Abordar o fenômeno artístico como sistema em constante transformação exige dos agentes desta organização, sejam artista ou espectador, um olhar atento às oscilações que dinamizam o evento, exige um exercício dinâmico de perda e descoberta de novos sentidos, o que coincide com a produção de conhecimento.

Tais condições surgem ainda como importantes fatores que contribuem para 0 pensamento e prática nos processos de produção e educação do artista contemporâneo. A educação como o desdobramento de experiências estéticas que produzem pensamentos espaciais, suspensões e paragens. 


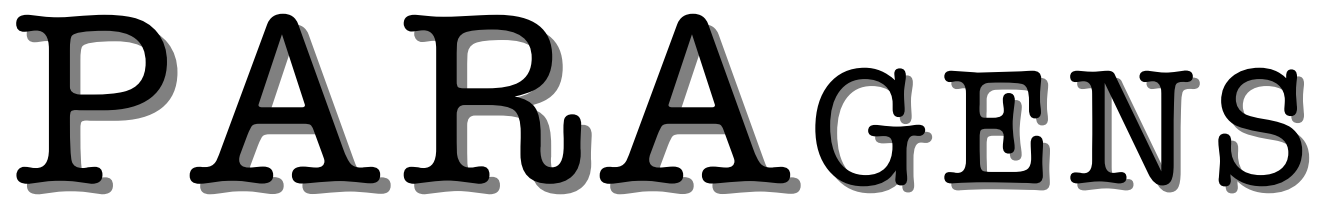

“...em suma o experimental não é "arte experimental"

os fios soltos do experimental são energias que brotam para um número aberto de possibilidades..." (Hélio Oiticica. Experimentar o experimental. 2009:109) 


\section{Paisagens em suspensão}

Há alguns anos que meu olhar observa linhas e formula paisagens transitórias. Caminho por cidades e desenho lugares escondidos, frestas que me saltam aos olhos e suspendem meu corpo. Um susto, a condensação e o cruzamento de tempos e qualidades que alteram a minha percepção. Uma dança constante com objetos, paredes, muros e janelas antigas. Paro com os pés descalços sobre as calçadas de pedras para deixar que a temperatura do solo toque os meus ossos. Resíduos de gerações inteiras, passos e corpos que se diluem com o tempo. Habito lugares em transição, prédios e estruturas efêmeras, e é nessas passagens que meu corpo se dissolve em linhas, pontilhados e intervalos que se sobrepõem e ativam vetores e forças incisivas que me impulsionam para lugares desconhecidos, que me apresentam camadas e intensidades que me fogem aos olhos. Esse olhar que desfoca os pontos fixos de observação cria pensamentos improváveis, transitivos e dinâmicos que compõem paisagens frágeis e ambientes suspensos, lugares porosos e em constante construção.

Levando-se em consideração que os pontos de equilíbrio não estão necessariamente no centro da figura, mas antes espalhados por diferentes pontos da paisagem, o pensamento segue uma lógica parecida. Não há uma linha reta, central e regular capaz de deter as múltiplas possibilidades e perspectivas que se manifestam enquanto o pensamento se constrói.

A superação de modelos que se pautam na estabilização de formas e conceitos coincide com a observação dos fenômenos sob um ponto de vista descentralizado no qual o ponto de fuga percorre trajetos inusitados.

A virada do século XIX para o século XX presenciou importantes transformações sociais, econômicas e filosóficas que traçariam novos modos de pensar e agir no mundo. A supremacia da razão provocou questionamentos que reorientaram noções e conceitos sobre a própria noção de conhecimento. Mudanças decisivas que reverberaram em diferentes direções e provocaram a transformação de paradigmas.

A filosofia, que vem abrindo mão da afirmação de uma verdade universal, sobretudo com o enfrentamento da ideia do absoluto, noção pontualmente refutada por Friedrich Nietzsche (1844-1900), surge como parceira e aliada na construção de olhares múltiplos capazes de atravessar paisagens sob as mais diversas direções e sentidos.

Filósofos como Maurice Merleau-Ponty (1908-1961), Gilles Deleuze (1925-1995), Félix Guatarri (1930-1992), entre tantos outros, produziram uma ampla literatura que foi e continua sendo intensamente utilizada como referencial para propostas teóricas ou práticas 
que enfatizam a constituição do sujeito e a produção de conhecimento sob uma perspectiva dinâmica de relação.

Se o pensamento cartesiano parte de pressupostos estáveis que traçam regras e constroem referenciais fixos, abordagens do pós-estruturalismo e, sobretudo da fenomenologia lançam linhas e traços complexos nos quais as relações se dão em rede, percorrem caminhos imprevisíveis e confrontam o sujeitos com múltiplas e inesperadas associações, quedas, pausas e silêncios.

Neste contexto, importantes contribuições da fenomenologia foram tecidas por Merleau-Ponty. O filósofo francês aborda o sujeito como processo, como instância em constante devir e que apreende o mundo em suas relações perceptivas com o entorno. Sua capacidade de perceber, de interagir corporalmente com o mundo coincide com o ato de conhecer.

A fenomenologia e correntes consideras pós-estruturalistas têm exercido uma forte influência no pensamento e na produção de arte, sobretudo, a partir de meados do século XX. Temas e abordagens filosóficas que priorizam os processos e as relações despertam o interesse de artistas e geram problematizações presentes em propostas e procedimentos da arte contemporânea. Se as vanguardas artísticas do início do século XX, principalmente, impulsionaram reflexões e atitudes que lançaram o evento artístico a experiências múltiplas, sensoriais e dinâmicas, o que vemos hoje é uma espécie de reverberação dessas iniciativas que aparecem no livre trânsito e nos intervalos entre suportes, linguagens e perspectivas.

As propostas artísticas do início e meados do século XX criaram importantes diálogos com a filosofia e com áreas outras do conhecimento que facilitariam intercâmbios e aberturas que estimularam a observação do fenômeno da arte sob novas perspectivas. A mobilização do olhar, dos sentidos e a construção de dinâmicas que assumem a instabilidade e a indeterminação presentes em conceitos como corpo e espaço marcam o surgimento de um ponto de observação móvel presente em importantes investidas de movimentos de arte de vanguarda.

A rejeição de definições que incentivam a construção de verdades absolutas é uma das principais linhas de contato que observamos hoje no contato entre a arte e a filosofia. E é nessa conversa calorosa que a arte estabelece com a filosofia e vice-versa que detectamos o surgimento de importantes estímulos que multiplicam os pontos de vista sob a arte contemporânea. A ruptura com os grandes esquemas, com moldes que asseguram o formato de esculturas, quadros e peças de teatro é um dos principais pontos de desestabilização que incitará a observação do fenômeno da arte sob um ponto de vista processual e em constante 
movimento de constituição e desaparecimento.

Rever noções de tempo, espaço, lugar, conceitos, sentidos e significados coincide com a expansão das limitações linguísticas que nos impedem de perceber como o sentido desliza de um lugar para o outro, de um elemento para o outro, de uma coisa para a outra. Talvez seja a possibilidade de religar as coisas, de conectar aquilo que o racionalismo, abordagens objetivas e as formatações trataram de separar. Permitir novas organizações e composições condiz com a produção de pensamentos e conhecimentos que se manifestam no corpo, nos sentidos antes mesmo de podermos localizá-los conceitualmente. De acordo com o autor João Francisco Duarte Júnior: "O mundo, antes de ser tomado como matéria inteligível, surge a nós como objeto sensível." (2006:13)

O pensamento que aparece como ação e interação com o entorno anuncia novas estratégias e abordagens para o fenômeno da arte.

A arte como enquadramento de realidades ou subjetividades se abre a experimentações e passa a ser compreendida como campo de forças no qual conceitos e pensamentos são regulados por movimentos contínuos e instáveis que provocam os sentidos.

A área plana se desdobra em estruturas tridimensionais que ao se relacionarem com o corpo, com o participante, são ativadas e dão lugar a um desenho complexo no qual vetores e forças de diferentes intensidades e direções se cruzam.

Um campo fenomenológico é gerado no encontro e na dispersão entre corpos e situações ambientais enquanto o espaço é investigado.

A mudança do meu ponto de observação do acontecimento teatral, da cena, do palco, do centro de uma figura ou de um conceito que é, com frequência, atribuído ao teatro, me possibilitou a criação de novas perspectivas e reflexões não só sobre o teatro, como também sobre a experiência artística, em sua compreensão mais ampla.

Neste ponto, relaciono as aberturas aqui propostas com considerações sobre os processos de conhecimento e educação. Processos experimentais e não categóricos jogam os saberes para um campo relacional onde não há nada a ser transferido, mas tudo a ser experimentado e sob os mais diversos pontos de vista.

A produção de Forsythe é permeada por especulações espaciais, relacionais e fenomenológicas que evidenciam pactos entre corpo e espaço. Essa perspectiva que dá ênfase a aspectos relacionados à percepção, aos sentidos, à atenção e ao modo como nos relacionamos com o mundo, diz respeito a um projeto que prevê, em última instância, e dentro do recorte aqui apresentado, considerações sobre uma educação estética.

Nas propostas de Forsythe, as mudanças de perspectiva, os referenciais espaciais e os 
diálogos aqui construídos com as artes visuais possibilitam um olhar sobre o fenômeno teatral a partir de considerações que evidenciam o ato perceptivo, a atenção e as relações que tecem ambientes nos quais corpo e espaço estão implicados. Essas informações sugerem contribuições entre áreas, campos e a intersecção de conhecimentos como fator fundamental na produção de arte e de pensamentos transitivos que se manifestam em relações do corpo e dos sentidos com o meio. Esses aspectos falam sobre condições e qualidades enfatizadas por uma educação sensível que aparece neste estudo nas estrelinhas das considerações sobre espaço, corpo e percepção.

É comum nas artes visuais o observação do espaço, das linhas que se sobrepõem, dos ângulos, das condições que incorporam aspectos temporais, da duração dos eventos. É frequênte o olhar para intervalos, cheios, vazios, dispersões de luz, frestas e pontos que transitam entre nervuras de folhas suspensas que logo se dispersam em novas tonalidades. A atenção para esses aspectos materiais, físicos e temporais coincide com uma aproximação e fusão dos sentidos com o entorno. Espacialidades são geradas enquanto minha percepção aciona e é acionada por elementos e qualidades que compartilham o ar comigo. Articulações e uma abordagem ambiental do espaço permitem que a percepção acesse nuances e variações que acontecem em detalhes que muitas vezes nos passam desapercebidos.

Aproprio-me então dessas indicações, que são amplamente investigadas pelas artes visuais, para lançar um pensamento sobre o fenômeno da arte sob uma perspectiva espacial e aderente no qual as interações são decorrentes de dinâmicas e deslocamentos do corpo, de meu campo perceptivo no mundo.

A partir de experiências práticas e de meu ponto de vista como atriz, como artista que se coloca diante do outro, problemáticas e reflexões estéticas me pareceram fundamentais para a investigação de um fenômeno no qual presenças, corpos e espaços são compartilhados. Estar diante do espectador é colocar-se à disposição, é gerar linhas conectoras que ativarão o olhar para cantos esquecidos, é produzir perturbações que agitarão o ar e provocarão perdas súbitas de orientação, é provocar o surgimento de constelações espaciais desconhecidas e multiplicar as possibilidades de observação sobre nós mesmo, sobre o outro e sobre o mundo.

Entre as orientações possíveis para a análise desse fenômeno no qual corpos são colocados diante de outros corpos em um ambiente pulsante que interfere nas relações que são produzidas, considerações estéticas me pareceram bastante pertinentes para a construção de pensamentos que ampliam o olhar sobre a produção artística para além dos suportes e das estruturas limitadoras de funções. Gerar espaços, ações e mover a percepção é tarefa que prevê mobilizações do corpo, assim como a dinamização de vínculos entre corpo e espaço. E 
é sob esse ponto de vista que articula possibilidades para o olhar e para a percepção que aspectos estéticos passaram a fazer parte e a orientar minhas leituras e pesquisas práticas e teóricas.

Sob esta perspectiva, apresento problemáticas que incentivam reflexões sobre possibilidades de uma educação estética no contexto da formação do artista contemporâneo. Exponho pensamentos que contribuem para um breve mapeamento de questões que sinalizam a educação do artista por um viés estético a partir de considerações sobre qualidades e situações que destaquei nas propostas de William Forsythe. Esta seção é um olhar rápido e uma abertura para um assunto que poderá ser ainda investigado em diferentes contextos e a partir de diferentes referenciais e perspectivas.

\section{Uma perspectiva estética}

É possível que o interesse estético apresentado neste estudo tenha sido despertado também por estudos e práticas em museus de arte. O trabalho na área de educação em museus e centros culturais em São Paulo me possibilitou um estudo diário de abordagens e relações que acontecem na tensão com limites institucionais. A criação de atividades práticas, os materiais de estudo disponíveis em cada nova exposição e a sugestão de percursos que ativam o olhar para linhas, contornos, sombras e formações incitam a sensibilidade a um exercício constante de apreensão de novos pontos de observação. A assimilação do entorno e as pontes que vinculam o meu olhar ao ambiente e à arquitetura heterogênea da cidade, sugeriram importantes pontos de contato entre as paisagens que meus sentidos percorrem e o acontecimento teatral. A sobreposição de espaços, a possibilidade de observação a partir de uma aproximação sensorial e física e a produção de conhecimento no encontro e nas interações do corpo com o espaço foram alguns dos pontos de partida para a observação do teatro em situações que não aquelas marcadas pelos referenciais teatrais institucionalizados. Passei a pensar o museu, o espaço expositivo e as atividades educativas em centros de arte como iniciativas que sugestionam o surgimento de um lugar teatral. De que modo que essas propostas que tratam do olhar, de marcas, memórias, camadas, intensidades e aberturas da percepção dialogam com o espaço teatral contemporâneo?

Eu caminhava pelo espaço expositivo e lá eu percebia qualidades e condições que experienciava também no teatro. O tempo corria em outro compasso, meu corpo freava tarefas e abstrações que me jogavam sempre para frente, para lugares imaginários, e eu parava para 
observar e construir linhas pelo espaço. O trabalho com arte e educação em museus é pautado em orientações que dão ênfase à percepção, ao modo como me relaciono com os trabalhos em diferentes situações. Essas situações se apresentam em projetos curatoriais que criam, muitas vezes, possibilidades de acesso a zonas nas quais os sentidos passam a interagir com condições espaciais que se aproximam e dialogam com condições teatrais. Em minhas experiências pelos corredores e ambientes expositivos eu vivenciava condições e qualidades teatrais. Eu não estava em cena, mas o teatro estava presente. Esses lugares me ofereciam variações para o olhar, a suspensão do tempo cotidiano e um ambiente de intensidades, camadas, sons, cheiros, contrastes, texturas e sensações se instaurava.

No jardim do museu, sons se transformavam em desenhos e lá nasciam também pensamentos, novas conexões que me permitiam ver sob pontos de vista precários e instáveis.

Passei a pensar e a relacionar esse exercício com as condições teatrais. De que modo essa flexibilização ou dispersão do olhar de um único referencial poderia contribuir para a prática e para o pensamento do teatro?

Observar áreas sob diferentes pontos de vista relaciona-se com uma reflexão sobre o fenômeno da arte como um amplo campo de experimentos e produção de conhecimento, o que coincide com uma educação estética ou sensível. Referências se cruzam, informações se encontram e o fenômeno artístico surge como lugar que extravasa linguagens, modelos ou regras. Aquilo que justifica a arte não se fundamenta naquilo que vemos, mas naquilo que legitima seu movimento e a sua constante reinvenção. Essa mobilidade parece ser um exercício fundamental para aqueles que trabalham com arte ou mesmo se interessam pela construção de pensamentos que extrapolam as lógicas e fórmulas impostas aos sentidos e sensos comuns.

Diante desta perspectiva móvel e flexível que promove aberturas aos sentidos e à percepção, sugiro uma breve reflexão sobre esse terreno movediço que dialoga com noções nômades que coincidem com conceitos como performance e experimental.

\section{Noções nômades}

As problemáticas e temáticas apresentadas neste trabalho sugerem uma aproximação imediata de considerações sobre o estudo e a prática da performance. E de fato as qualidades aqui analisadas, ao abordarem prerrogativas como abertura, trânsitos e dinâmicas, dialogam diretamente com aspectos e com a própria noção de performance no contexto da produção em 
arte. Contudo, opto por um recorte e por considerações que observam ramificações e práticas experimentais do teatro sem com isso recorrer a transferência de um campo para o outro.

Estudos da performance estão presentes nesta pesquisa em reflexões que ampliam o entendimento do fenômeno da arte e favorecem o cruzamento entre referenciais. Aspectos da performatividade e da teatralidade participam também das discussões aqui levantadas. Entretanto, essas qualidades que acompanham as discussões aparecem sob o ponto de vista da prática teatral, das teatralidades contemporâneas.

O teatro, conforme a abordagem deste estudo, diz respeito à produção de espacialidade na qual múltiplos pontos, linhas e traços se espalham, não repousam em nenhum lugar fixo, mas antes se deslocam por becos, brechas e intervalos inimagináveis.

Outra questão importante que deve ser problematizada é uma tendência à associação imediata entre propostas que abordam dinâmicas com a noção de performance. Essa associação automática pode ser questionada, já que nem toda proposta que carrega o nome de performance está realmente atenta às condições que se propõe.

Abordar variações e dinâmicas no contexto da formação do artista é também aproximar a prática em arte de pressupostos enfatizados pela performance, por esse campo que se infiltra em tantos outros e que foge de uma localização determinada. Entretanto, o que vemos hoje como performance tende, em muitas situações, a fazer parte de protocolos e premissas repetitivas. Aquilo que se propõe à ação e à perturbação dos sentidos está muitas vezes fundamentado em regras e modelos que sufocam o seu surgimento em possibilidades inusitadas, em ações que provoquem reorganizações físicas e reflexivas sobre os eventos. Os acontecimentos que nomeamos performance, nas artes, caem muitas vezes na armadilha que qualquer manifestação tende a cair quando passa a considerar sempre os mesmos referenciais.

É importante destacar aqui as considerações feitas pelo autor Marvin Carlson sobre as diferenças nas discussões e tratamentos da performance e do teatro nos estudos nos Estados Unidos e na Alemanha.

Marvin Carlson assina o texto de introdução do livro "The Transformative Power of the Performance", de Erika Fischer-Lichte, e pontua importantes e decisivas diferenças sobre as abordagens da performance no contexto dos Estados Unidos e no ambiente investigativo da Alemanha. Ainda que as diferenças não se resumam a perspectivas constituídas por um único ponto de vista ou pela produção de leituras e sentidos homogêneos que definiriam uma identidade americana e uma alemã no que se refere ao estudo da performance, Carson, neste texto introdutório, nos apresenta um importante panorama de tendências que justificam as escolhas e os recortes de estudos propostos sobre a performance e o teatro nos Estados Unidos 
e na Alemanha.

Para entender essa diferença, Martin Carlson volta ao início do século XX e pontua variações e tendências que fundamentam o início dos estudos teatrais nos Estados Unidos.

Característica gerais pontuaram diferentes orientações na formação dos programas vinculados aos estudos do teatro no oeste e no meio leste dos Estados Unidos. Entretanto, muitas universidades criaram, ainda no início do século $\mathrm{XX}$, algo semelhante ao "performativ turn" que, de acordo com Carlson, Erika Fischer-Lichte localiza seu aparecimento na Alemanha, aproximadamente no mesmo período.

Essas diferenças são perceptíveis ainda hoje, de acordo com Carlson. O que se percebe é que o estudo da performance surge, de um modo geral, como oposição ou como elemento que contribui para a construção de novos diálogos no âmbito do programa de estudos teatrais existente.

\begin{abstract}
Uma importante distinção intimamente relacionada entre os estudos modernos de performance na Alemanha e nos Estados Unidos, particularmente nos anos de formação deste campo, foi que esta nova área teve um relacionamento conturbado e um pouco contraditório com o campo já estabelecido de estudos de teatro. $\mathrm{Na}$ Universidade de Nova Iorque, o teatro tende, na melhor das hipóteses, a ser considerado como uma área menor e bastante especializada de trabalho dentro de um campo muito mais amplo, representado pelos estudos da performace, caracterizado por Richard Schechner como "uma fatia muito pequena da performance." Na pior das hipóteses, os estudos da Performance definem-se a si mesmos em oposição direta aos estudos de teatro. (CARLSON em FISCHERLICHTE, 2008:3, tradução nossa) ${ }^{216}$
\end{abstract}

O que se percebe é que no contexto americano há uma tendência à separação, a dissociação de tais práticas, enquanto que na Alemanha o estudo da performance e do teatro se cruzam, se misturam e tendem a promover a abertura do conceito de teatro.

Nos Estados Unidos, ainda que existam variações de abordagens em diferentes localidades ou instituições, como esclarece Carlson, há uma tendência de aproximação do conceito de performance ao campo da antropologia e dos estudos sociais.

Na Alemanha, no entanto, nenhuma divisão ou distanciamento a partir de estudos de teatro resultou da evolução das disciplinas acadêmicas. $O$ campo de Theaterwissenschaft (estudos do teatro), criado no início de 1920 por Max

\footnotetext{
${ }^{216}$ Texto de apresentação de Martin Carlson no livro "The Transformative Power of the Performance", de Erika Fischer-Lichte, 2008. Texto original: "A closely related important distinction between modern performance studies in Germany and in the United States, particularly in the formative years of the field, was that this new field had a troubled and somewhat contradictory relationship with the already established field of theatre studies. At New York University, theatre tended at best to be regarded as a minor, rather specialized area of work within the far broader field represented by performance studies, characterized by Richard Schechner as "a very small slice of the performance pie." At worst, performance studies defined itself in direct opposition to theatre studies." (Carlson, 2008:3)
} 
Herrmann, definiu-se, como os programas paralelos iniciais de teatro nos Estados Unidos, em oposição ao estudo tradicional do texto literário (Literaturwissenschaft), mas como Herrmann baseou esta oposição dos estudos de teatro como um evento social e um processo de ação corporificada, em vez da comunicação de um texto literário, sua versão dos estudos teatrais foi muito mais compatível com as preocupações mais tarde desenvolvidas por estudos modernos da performance. Assim, os programas alemães em Theaterwissenschaft, como aquele liderado por Fischer-Lichte, nunca sofreu as tensões e divisões entre teatro e performance, que foram frequentemente mais sentidas nos Estados Unidos. (Carlson em FischerLichte, $2008: 3$ e 4 , tradução nossa) ${ }^{217}$

As considerações de Carlson auxiliam na visualização da noção da performance em diferentes contextos. Um olhar sobre as questões destacadas pelo autor incitam reflexões sobre uma tendência à separação e à constituição de áreas ou domínios de conhecimento específicos mesmo nos processos de educação em arte. Por mais que os campo gerados sejam amplos e permitam as mais variadas abordagens, eles formam pedaços, fatias e estabelecem deste modo parâmetros e delimitações.

Produzir campos abertos não seria gerar fios e pontos dispersos que não se acomodam em nenhum local específico? Não seria a possibilidade de observar eventos e categorias sob pontos de vista mais flexíveis e experimentais? Coloco essas questões como modo de problematizar a educação como processo associado a uma área ou a um campo determinado.

A possibilidade do experimental, do contínuo processo de desvendar caminhos estranhos, ignorados ou mesmo desabitados, parece se aproximar do exercício de gerar desdobramentos nas mais variadas direções sem a obrigação de se criar, com isso, novas especializações sejam elas amplas e dinâmicas ou não.

Pontuo então o experimental como aquilo que está e não está, que se manifesta e não se manifesta em diferentes situações, campos e áreas. O movimento ou o intuito em promover alterações em questões e estruturas fechadas pode acontecer a qualquer instante e em qualquer situação. É ato que acontece no teatro, nas artes visuais, na dança, na ciência, na história e nos mais variados campos de estudo. As trepidações que giram o ponto de observação não dependem de um estatuto ou da criação de novos modelos ou referenciais. Qualquer salto ou respiro fora das expectativas de algum manual são importantes para a circulação e a criação

\footnotetext{
${ }^{217}$ Texto original: "In Germany, however, no such division or distancing from theatre studies resulted from the evolution of the academic disciplines. The field of Theaterwissenschaft (the study of theatre), established in the early 1920s by Max Herrmann, defined itself, like the parallel early theatre programs in the United States, in opposition to traditional study of the literary text (Literaturwissenschaft), but since Herrmann based this opposition on the study of theatre as a social event and a process of embodied action rather than the communication of a literary text, his version of theatre studies was far more compatible with the concerns later developed by modern performance studies. Thus German programs in Theaterwissenschaft, like that headed by Fischer-Lichte, never suffered from the tensions and divisions between theatre and performance that were frequently felt in the United States." (Carlson em Fischer-Lichte, 2008:3 e 4)
} 
de novos modos de sentir e se relacionar com o mundo.

Hélio Oiticica $(1972)^{218}$, em suas colocações sobre o experimental, fala da produção de atos indefinidos e em aberto que estimulam a produção de materiais e situações desconhecidas. A palavra "experimental" é apropriada, não para ser entendida como descritiva de um ato a ser julgado posteriormente em termos de sucesso e fracasso, mas como um ato cujo resultado é desconhecido. "Experimentar o experimental" é ativar passagens, relações e interações que alterarão circunstâncias e padrões conhecidos. É colocar o olhar em órbita e permitir que o corpo e os sentidos se reinventem e descubram novas rotas, acessos e direções.

Incentivar perspectivas sensíveis nas relações que criamos com o mundo diz respeito à construção de passagens e de caminhos que se aproximam de ideia de Delírio Ambulatorium, de Hélio Oiticia:

O Delírio Ambulatório é um delírio concreto. Quando ando e proponho que as pessoas andem dentro de um penetrável com areia e pedrinhas, estou sintetizando minha experiência da descoberta da rua através do andar, do espaço urbano através do detalhe de andar, do detalhe da síntese do andar.

(OITICICA, 1978 apud CAMPBEl, 2008:21) $)^{219}$

Essa perspectiva experimental trata de uma educação estética que prevê a interação entre conhecimentos práticos, teóricos e apoiados nos mais variados referenciais físicos e conceituais. O que está em jogo é a aventura de sobrevoar acontecimentos e misturar linhas para que as perspectivas de acesso se multipliquem.

Exponho, a seguir alguns dos eixos que auxiliaram no percurso deste estudo como modo de apresentar questões e problemáticas que indicam aberturas para investigações sobre uma educação comprometida com movimentos que se aderem ao meio e procuram pontos de ressonância que evidenciam o sensível. Um contato com o mundo em estado de vibração, antes de se fixar em normas ou conceitos, gera mudanças no corpo, nos pensamentos e na produção de espaços.

Começa aí, portanto, nesse "corpo-a-corpo" primeiro mantido com o mundo que nos rodeia, a aventura do saber e do conhecer humanos. Sem dúvida, há um saber sensível, inelutável, primitivo, fundador de todos os demais conhecimentos, por mais abstratos que estes sejam; um saber direto, corporal, anterior às representações simbólicas que permitem os nossos processos de raciocínio e reflexão. E será para

\footnotetext{
${ }^{218}$ Reflexões de Oiticica no texto "Experimentar o experimental" publicado no livro Encontros- Hélio Oiticica, 2009.

${ }^{219}$ Texto disponível na dissertação de mestrado "Canteiro de obras, deriva sobre uma cidade-pesquisa habitada por práticas artísticas no espaço público”, de Brígida Campbel, 2008, MG. Disponível no link:

https://www.ufmg.br/online/arquivos/anexos/Brigida_Campbell.pdf.pdf. Acesso em julho de 2015.
} 
essa sabedoria primordial que deveremos voltar a atenção se quisermos refletir acerca das bases sobre as quais repousam todo e qualquer processo educacional, por mais especializado que ele se mostre. (DUARTE Jr., 2006:12)

\section{O desenho}

Apresento um episódio do meu processo de educação que demonstra a dificuldade dos métodos que dão ênfase à divisão dos campos de conhecimento e a limitação dos referenciais de acordo com domínios e padrões pré-estabelecidos.

O verdadeiro limite do desenho não implica de forma alguma o limite do papel, nem mesmo pressupondo margens. Na verdade o desenho é ilimitado, pois que nem mesmo o traço, esta convenção eminentemente desenhística, que não existe no fenômeno da visão, nem deve existir na pintura verdadeira ou na escultura, e colocamos entre o corpo e o ar, como diz Da Vinci, nem mesmo o traço o delimita. (ARTIGAS, Vilanova, 1975, apud TAVARES, Andrea, 2015),220

Sempre tive especial interesse por esquemas, desenhos, linhas e contornos. Há nos pensamentos algo que se aproxima da complexidade de traços que se manifestam nos desenhos. Enquanto conceitos parecem ser facilmente traçados, os pensamentos necessitam de campos livres, dinâmicos, abertos e navegáveis para a sua manifestação. E como desenhar pensamentos? O desenho a que me refiro é composto por planos, profundidades, dimensões e medidas complexas. Desenho é força resultante de interações, de um conjunto de forças, é aquilo que se coloca em movimento. Algo que está suspenso, que oscila, qualidade e conceito pautado em propriedades físicas e conceituais.

O desenho livre sempre foi a minha maior dificuldade. Os meus desenhos livres eram todos repetições de uma mesma fórmula, a única que eu conhecia e sabia reproduzir. E sempre que me pediam para fazer um desenho livre eu desenhava a mesma coisa, duas montanhas com um sol enorme entre elas.

Sempre gostei de geometria, de formas soltas e aleatórias no espaço. Gostava de multiplicá-las, fragmentá-las. Mas isso não era desenho, era geometria. Aulas de geometria substituíam as aulas de desenho e as aulas de desenho eram aulas de desenho livre. E entre uma coisa e outra eu repetia aquilo que conhecia, mas me questionava sempre sobre o tal

\footnotetext{
${ }^{220}$ Citação disponível na tese de doutorado "Curso de desenho por correspondência", de Andrea Paula Parreira Tavares, 2005, SP. Disponível no link: www.teses.usp.br/teses/disponiveis/27/.../AndreaPaulaPereiraTavares.pdf Original do texto em: ARTIGAS, Vilanova. O desenho. In: SOBRE Desenho. São Paulo: Centro de Estudos Brasileiros do Grêmio da Faculdade de Arquitetura e Urbanismo da Universidade de São Paulo, 1975. Texto da aula inaugural de Vilanova Artigas na FAU-USP em 1967.
} 
desenho livre. Haveria outra possibilidade para o desenho livre ou ele era apenas esse que ocupava todas as folhas em branco que me entregavam para desenhar? Sem referenciais práticos para experienciar o espaço, para observar ficava aprisionada em pensamentos, ideias imobilizantes - como um desenho livre pode ser.

Já adulta passei a desenhar meus pensamentos. Vejo melhor as ideias em linhas, pontos e curvas que ora tocam o corpo, ora a pele e ora folhas finas de papel. Os desenhos são essas estruturas que facilitam o meu dialogo com o vazio, são os rabiscos que me esvaziam, que dão vazão para o amontoado que empilho em pensamentos e possibilitam o novo.

Os desenhos são uma mistura fina entre matéria e abstração, são pontos de encontro de palavras que não consigo pronunciar, são paragens do meu olhar que refazem paisagens, são incursões espaciais nas quais meus sentidos aprendem novos ritmos e texturas. A contradição. Impulsos apaixonados e a profunda serenidade dos lagos entre as montanhas de neve. É dar oportunidade ao acaso, ao imprevisto. É exercitar aberturas, é aprender mapas que serão rabiscados, é conhecer os lugares conhecidos da cidade para encontrar becos com múltiplas saídas.

O desenho me acompanha, mesmo que eu não saiba desenhar quando tenho um lápis e um papel nas mãos. Desenho as minhas ideias. Monto esquemas, rabisco dúvidas e crio traços que me ajudam a formular e organizar as questões que me ocorrem. Nesses desenhos há sempre linhas que escapam, que desviam e me lançam para trajetos improváveis. Depois de muito tentar ligar pontas de fios soltos, constato que é nesses lugares frágeis e desconhecidos que meus pensamentos se reinventam. A dinâmica entre uma infinidade de abstrações e o esforço do meu corpo de sintetizar em gestos, frases, volumes geométricos, textos e silêncios esse emaranhado de informações. Meus desenhos são explorados em relações aéreas, em rabiscos amassados, em textos que guardo em cadernos antigos e amarelados. O desenho era uma previsão de interesses espaciais que eu viria a pesquisar no teatro. E quando comecei a investigar o desenho?

Para aprender a desenhar comecei a atuar. No teatro percebo variações possíveis de desenhos livres improváveis. Rodopio e percorro intensidades que minhas mãos não tem habilidade para imprimir em grafias sobre a folha do papel.

Sozinha na sala de ensaio. Quando começo a ensaiar os objetos começam a se mover, o chão trepida e meu corpo se dissolve em texturas que percorrem o espaço. Sala de ensaio é ambiente, é instalação e arquitetura que surge e desaparece com as dinâmicas que são produzidas. 
De acordo com Paul Klee ${ }^{221}$, os desenhos podem ser observados a partir de indicações sobre linhas, pontos e temporalidades:

\begin{abstract}
O elemento tempo pode ser muito melhor reconhecido no caso da linha do que no ponto, uma vez que a extensão é um elemento temporal. Uma linha é um ponto que saiu para passear. Quando um ponto se torna movimento, e portanto linha, isso implica tempo. A mesma coisa ocorre quando uma linha se desloca para formar um plano. E igualmente no que diz respeito ao movimento dos planos para formar espaços. Espaços são planos que saíram para passear. (KLEE, 2001)
\end{abstract}

Que condições são essas que fazem com que o espaço deixe de ser mensurado para ser criado em ação? Que lugar é esse que é produzido quando estou ensaiando? E como observar essas dinâmicas e condições em diferentes situações? A experiência que vincula matéria e tempo provoca deslizes que me imprimem no espaço.

No decorrer desta pesquisa me ocorreu que a liberdade de um desenho livre está na variedade de ferramentas e orientações que tenho a minha disposição. Se não estudo e analiso contornos e possibilidades de gerar pensamentos, os atos ficam aprisionados nos mesmos referenciais e eu repito sempre as formas conhecidas. A investigação de propriedades, a observação de aspectos objetivos e que se manifestam na matéria provocam o olhar e acionam linhas que pareciam estáticas. As linhas se movem enquanto o pensamento experimenta variações. As estruturas planares, geométricas e estáveis auxiliam na visualização de oscilações, de qualidades subjetivas e especulações filosóficas e fenomenológicas que confundem posições e pontos de vista estáveis.

Essas considerações sobre as dinâmicas a partir de interações e deslocamentos espaciais conduzem a uma reflexão sobre a importância da construção de trajetos particulares e singulares no processo de educação sob um perspectiva estética.

Qual a importância da construção de percursos particulares ou experiências estéticas em uma prática que prevê ações coletivas? De que modo as diferenças geram matizes para um pensamento sobre o encontro e o coletivo no contexto atual? Estar junto não como ato de adesão a um pensamento dominante ou com o intuito de gerar um bloco homogêneo, mas de compartilhar olhares, temperaturas, alterações atmosféricas e ambientais.

Sigo então algumas pistas, linhas, contornos que podem auxiliar na construção de percursos autônomos e singulares nos quais o artista se coloca como criador, provocador, desenhista de ambientes que avançam, que se expandem para além do acontecimento artístico

${ }^{221}$ KLEE, Paul. Sobre a arte moderna e outros ensaios. Rio de Janeiro: Jorge Zahar, 2001. 
e provocam giros, silêncios e um sobrevôo que desestabiliza sentidos e provoca a percepção. Estar junto, rabiscar palavras, mover o chão, apontar infinitas direções do olhar, ouvir sons que só acessamos com os olhos fechados, revelar as batidas do coração e a profusão de pensamentos que o corpo é capaz realizar, desdobrar imagens, desfocar e multiplicar os planos, eis algumas das tarefas da educação e dos artistas no contexto atual.

\section{Educação estética}

A educação estética parece se relacionar com algum tipo de desaceleração do olhar e suspensão de sentidos acostumados a desenhar o mundo sob uma mesma perspectiva. É no contexto da uma educação estética que novas relações e rotações para o olhar são construídas. O corpo, a percepção e o pensamento são acionados em outras direções e novas incursões espaciais geram novas possibilidades de mundo, de realidade e interação com o entorno. De acordo com o autor João Francisco Duarte Júnior: “Trata-se, antes, de um projeto radical: o de um retorno à raiz grega da palavra "estética" - aesthesis, indicativa da primordial capacidade do ser humano de sentir a si próprio e ao mundo num todo integrado.” (2006:13)

Neste processo de criar relações com o entorno algumas qualidades e metodologias auxiliam na construção de ações e espacialidades transitórias. A escuta, a abertura e a sensibilização do olhar são algumas das indicações de abordagens metodológicas ou pedagógicas que ressaltam procedimentos transdisciplinares em projetos e práticas que presumem o sensível e a descoberta de novos pontos de vista como parâmetro para a observação e interação com diferentes fenômenos.

Como artista, quais as qualidades que me auxiliam em meu trabalho? Como ativar minha percepção em diferentes níveis, como me relacionar com o entorno e permitir que diferentes estímulos reverberem e sejam assimilados por um sistema precário e frágil que é como linhas que conduzem a aparição e a apresentação de trabalhos de arte? Como atualizar esse sistema? Como permitir que ele seja cheio de vazios. Como criar estruturas claras, definidas e ainda assim dinâmicas?

Parece-me importante que o artista contemporâneo, inserido em um contexto de projetos transdisciplinares, experencie vôos por lugares temporários, porosos e que dê vazão aos sentidos que são construídos a partir de relações singulares, complexas e contraditórias com o mundo. Parece-me importante o olhar particular que compõe paisagens e reinventa o mundo em atos solitários ou coletivos.

$\mathrm{O}$ assunto desta pesquisa indica possibilidades de diálogos com a educação do artista. A 
educação aqui prevista é um processo vinculado a uma experiência estética que pode ser observada em considerações que fazem oscilar sentidos e definições. A expansão de conceitos, a prática do experimental e a negociação com estímulos físicos e materiais promovem rearticulações que lidam com a instabilidade dos eventos e sistemas em um processo contínuo de produção, organização e desaparecimento.

A experiência em arte sob a perspectiva móvel e experimental aqui apresentada coincide com o processo de conhecimento, com a ampliação de possibilidades para produzir sentidos e se relacionar com o mundo.

Neste ponto, considerações sobre uma educação estética refere-se à observação de referenciais improváveis e que transitam por esferas que parecem distantes, separadas ou mesmo contraditórias em relação ao já conhecido.

Pensar sobre a arte como forma de conhecimento em uma sociedade que, na maioria da vezes, dispõe de incontáveis meios para a obtenção, a produção e manipulação de informações, é gerar combustível para o pensamento e a prática de uma educação que rompe com modelos pautados na reprodução e na formatação de padrões reguladores de relações e percepções. A partir dos estímulos e das problemáticas presentes nos fenômenos artísticos, é possível refletir sobre o sensível nos processos de criação e na construção de percursos, gestos e traços particulares sobre o mundo.

Criar vínculos entre lugares que parecem não se comunicar é gerar pontos de acesso ao desconhecido e experimentar conhecimentos que acontecem no cruzamento de informações, texturas, tons, sonoridades e sensações que tecem ambientes plurais, que produzem heterotopias.

\section{A prática}

No contexto de formação do artista cênico, como cruzar as problemáticas acima mencionadas com a investigação prática de condições instalativas, espaciais e que levam em consideração aspectos materiais ao invés de leituras e interpretações pautadas em referenciais dramáticos ou textuais apenas? Sobre a ampliação de referencias na educação do artista cênico, a autora Juliet Rufford faz a seguinte reflexão:

Qual significado pode ser atribuído à combinação, ao entrelaçamento ou à justaposição de elementos dramáticos, texturas e/ou materiais? Como podemos ligar diferentes momentos dentro da performance e facilitar a transição do público entre eles? Quais conexões podem existir entre o trabalho e os seus contextos físicos, 
sociais, ideológicas, entre outros, e como eles serão articulados através de nossos corpos, de nossas palavras, do espaço, da luz e do som? (RUFFORD, 2015:71, tradução nossa) $)^{222}$

Rufford (2015) fala sobre a ênfase que ela percebe nas disciplinas de dramaturgia em aspectos como escrita, adaptação e leitura em detrimento de abordagens que levam em consideração qualidades espaciais, concretas e materiais. Essa característica pode ser observada a partir de evidências que aparecem em publicações de dramaturgia e tendências que ela menciona em seu contexto de atuação, na Inglaterra:

(...) a evidência em publicações inteiras sobre dramaturgia, bem como as descrições dos módulos de dramaturgia nos contextos universitários no Reino Unido e na Europa, mostram maior ênfase sobre as habilidades de escrita, re-escrita, tradução, adaptação, leitura e decodificação do que o incentivo às possibilidades de invenção e de se fazer teatro através de circunstância concreta, ação, material, conversa etc. (RUFFORD, 2015: 72, tradução nossa) ${ }^{223}$

A transformação utilitária e representacional do espaço em tramas espaciais que se formam pela ação sugere que o artista investigue articulações e mobilidades entre elementos. Instalar, criar ambientes temporários para os sentidos, para o olhar, para que surjam novos pensamentos. A observação do espaço teatral sob a perspectiva de um espaço instalativo que se monta, se desmonta, se dobra, se desdobra e se rearticula em múltiplas intensidades e vibrações desafia a atenção para relações aderentes que coincidem com condições e qualidades verificáveis em experiências estéticas.

Entre algumas das orientações que surgem no contexto das artes cênicas e que abordam a prática e o pensamento sob uma perspectiva espacial, menciono algumas das contribuições de Anne Bogard. Seus exercícios de improvisação, baseados na técnica do Viewpoints, dão ênfase ao espaço, às particularidades que compõem o ambiente com o qual o artista negocia. Aspectos da arquitetura, formas, volumes e toda interferência espacial é enfatizada em detrimento da construção de histórias e tramas previamente elaborados. Como me relaciono com o espaço? Como crio espaço? Como gero lugares, intensidades, camadas e relações?

\footnotetext{
222 Texto original: "What significance might be attributed to the combining, interweaving or juxtaposing of dramatic elements, textures and/or materials? How will we connect the different moments within the performance and facilitate the audience's transition between them? What connections might exist between the work and its physical, social, ideological and other contexts, and how will these be articulated through our bodies, our words, the space, light and sound? (Rufford, 2015:71)

${ }^{223}$ Texto original: “(...) the evidence of many full-length publications on dramaturgy as well as descriptions of the university dramaturgy modules in the UK and Europe, shows the emphasis falling more heavily on skills of writing, re-writing, translating, adapting, reading and decoding that it does on pushing the possibilities for formal inventiveness and for making theatre work through concrete circumstance, action, material, talk and craft." (Rufford, 2015: 72)
} 
Os Viewpoints são uma série de exercícios baseados no trabalho da dançarina Mary Overlie. Bogart, em sua abordagem, enfatiza o espaço, as relações e o modo como os artistas respondem aos estímulos espaciais. A materialidade desses espaços é ressaltada em detrimento da construção de espacialidades fictícias. Os artistas devem explorar fisicamente a arquitetura e se relacionar com o entorno de modo atento e consciente. A atenção aos detalhes e às frestas que compõem o espaço ativam relações físicas nas quais os mais variados agentes interpelam o campo perceptivo do artista. Os exercícios tendem a provocar o olhar para novas orientações e possibilidades de interação com elementos e qualidades que se apresentam nos demais corpos que transitam pelo espaço e nos aspectos arquitetônicos que evidenciam materialidades e a articulação entre formas e traçados espaciais. O corpo é lugar de escuta e passagem que trepida ao interagir com o meio.

Essa perspectiva ambiental e arquitetônica está entrelaçada com uma qualidade de atenção que é produzida na relação consciente com o entorno e não na afirmação ou na insistência em se relacionar de acordo com alguma regra ou imposição que leve à construção de narrativas pré-estabelecidas. Os contatos produzem qualidades e forças que não podem ser mensuradas de antemão. O corpo, neste contexto, precisa se aventurar e descobrir sentidos a partir de impactos que atravessam e ativam a percepção.

Um dos exercícios previstos pelo Viewpoints é o Flow, que é descrito pela autora Gray Read em seu blog "Archicture Acts" 224 - no qual ela comenta os exercícios de Anne Bogart e seus experimentos com estudantes a partir de jogos com princípios da arquitetura.

Isto funciona assim: Mova-se através de uma sala, torne-se consciente do espaço ao redor, acima e abaixo de você. Observe os detalhes. Olhe para as pessoas ao seu redor, faça contato visual, e perceba coisas sobre eles, enquanto continua atento à sala. Traga a sua consciência para incluir mais coisas e pessoas, usando a visão periférica para manter a forma do espaço e o movimento de outros em vista. Bogart chama esta prática de "soft focus". Deslocar-se em relação ao espaço e as outras pessoas, escolher uma pessoa ou coisa para rastrear mantendo a consciência de todo o espaço, em seguida, escolher duas pessoas e mover-se em relação a elas. $\mathrm{O}$ exercício continua com intensa atenção e movimento proposital que emerge em ação coordenada inteligível, ainda sem um líder ou parceiro pré-determinado. A orientação deste e de todos os exercícios de Bogart é desenvolver a consciência e a resposta a tal ponto que você se perde e se integra à fluidez da situação em tempo e espaço real. (READ, 2011, tradução nossa) ${ }^{225}$

\footnotetext{
${ }^{224}$ Texto "Spatial Improvisation for Architects", de Gray Read. Disponível no link:

http://architecture-performance.blogspot.de/2011/02/spatial-improvisation-for-architects.html. Acesso em: abril de 2015 .

${ }^{225}$ Texto original: "It works like this: Move through a room, become aware of the space around, above and below you. Notice the details. Look at the people around you, make eye contact, and notice things about them, while continuing to be aware of the room. Bring your awareness to include more things and people, using peripheral vision to hold the shape of the space and the motion of others in view. Bogart calls this 'soft focus.' Move in relation to the space and the other people, then choose one person or thing to track while maintaining
} 
Os exercícios de Bogart destacam a presença física dos corpos e dos estímulos da arquitetura. Os mais diversos objetos e formas, como janelas, cadeiras, mesas e a interação entre os corpos agem promovendo investigações de como criar relações em situações coletivas ou mesmo individuais. Como me relaciono com o ambiente? Como são criadas relações em um espaço compartilhado com outros corpos? Como que essas forças ambientais e físicas agem sobre a minha percepção e insinuam o aparecimento de novas linhas e interações imprevisíveis?

A pesquisadora e diretora Beth Lopes, no texto "Treinamento: a face e o dorso" ${ }^{226}$, fala sobre sua experiência junto à SITI $^{227}$ Company e do cruzamento das técnicas de Viewpoints e Suzuki: "o treinamento se constitui em um campo onde as correlações de forças desafiam o corpo e provocam uma espécie de metabolização de estados sensíveis adormecidos." A combinação dessas técnicas oferece ao artista condições que auxiliam na investigação de procedimentos que agem na fisicalidade e na atenção que potencializa as relações do corpo com o entorno. Lopes comenta: "Se o Suzuki permite ao performer o controle dos movimentos e da respiração, os Viewpoints desafiam esta ordem. O Suzuki é uma velha árvore frondosa enquanto os Viewpoints são a ventania que arranca suas folhas."228

O que os Viewpoints propõem é o exercício da ação que gera tensões e diálogos com o entorno. A superação dos padrões de resposta que determinam muitas vezes o modo como lidamos com estímulos é uma das questões fundamentais abordadas pela prática do Viewpoints. Neste ponto, vale citar as considerações de Caspersen ${ }^{229}$ sobre a execução de um movimento do balé sem que haja a repetição de um conjunto padrão de respostas, como prevê a abordagem de Forsythe: "Dançarinos virão todos os dias farão pliés, e todo dia você precisa se reconectar com a ideia de um plié em vez de pensar que você já o domina. É o mesmo em conflito; não se trata de ter um conjunto padrão de resposta, mas sobre praticar as ações mais

\footnotetext{
awareness of the entire field, then choose two people and move in relation to them. The exercise continues with intense attention and purposeful motion that emerges into intelligible coordinated action, yet without a leader or predetermined pattern. The thrust of this and all of Bogart's exercises is to develop awareness and response to the point that one loses oneself to the fluidity of the situation in real time and space." (Read, 2011).

${ }^{226}$ Texto "Treinamento: a face e o dorso" disponível no link: http://www.seer.unirio.br/index.php/opercevejoonline/article/view/1442/1246

${ }^{227}$ A SITI Company, que tem sede em Nova Iorque, é dirigida por Anne Bogart - que também é professora da Columbia University. A companhia oferece workshops nos quais as técnicas de Viewpoints e Suziki orientam os treinamentos.

${ }^{228}$ Texto disponível no link: http://www.seer.unirio.br/index.php/opercevejoonline/article/view/1442/1246

${ }^{229}$ Comentário disponível no site: http://www.nytimes.com/2015/04/26/arts/dance/a-william-forsythe-dancermoves-from-toe-tapping-to-handshaking.html?_r=0. Acesso em: abril de 2015.
} 
básicas de percepção, expressão e foco." ${ }^{230}$ Caspersen $^{231}$ destaca ainda, em seu processo de formação junto ao Ballet de Frankfurt, a orientação de Forsythe sobre o modo de ver e se relacionar sob diferentes perspectivas: "O que me formou nos primeiros anos aqui foi que Bill nos pedia para encontrar conscientemente diferentes formas de ver". ${ }^{232}$

A construção de novos modos de ver e se relacionar com o entorno fazem parte de metodologias e abordagens nas quais perspectivas estéticas e relacionais tendem a ampliar o campo perceptivo dos artistas. Estar atento ao percurso, aos desdobramentos do corpo no espaço e aos estímulos ambientais favorece a construção de experiências singulares e até mesmo fenomenológicas nas quais os deslocamentos serão sempre modificados. Beth Lopes tece considerações sobre esse assunto:

Para entender os Viewpoints, assim como na Fenomenologia, deve-se reconhecer o
mundo em que estamos inscritos antes de qualquer análise ou reflexão. Do quarto
andar da janela onde acontecem os workshops da SITI Company os performers são
estimulados a olhar para a rua e a reconhecer as relações intersubjetivas que se
articulam a partir daquele recorte. Para onde vão/vem, como vão, como passam
pelos outros, pelos carros, pelos prédios, pelas vitrines? Como andam e por que
param? O que olham? Como são: a rua, os prédios, as janelas (dentro e fora), a
arquitetura? A redescoberta do tempo/espaço e seus entrelaçamentos, chave das
improvisações, constitui a experiência destes elementos em seu próprio corpo e são
a fonte de toda composição discursiva. Esta descoberta vivencial e originária
fundamentada na vida constitui o conhecimento dos Viewpoints, uma pedagogia que
faz brotar do corpo inesgotáveis combinações de ações e reações para além do senso
comum.

No contexto da formação do artista cênico, a sensibilização do olhar, a atenção, a escuta e a abertura são condições que tendem a gerar um campo de forças que aproxima obra e público. O artista não está separado, mas em constante relação com o ambiente. Seus gestos sofrem interferências do entorno e interferem no meio. O encontro entre obra e espectador, sob este ponto de vista, se dá por pequenas frestas que o artista mantém na composição, produção e apresentação do seu trabalho. Zonas de instabilidade, de indeterminação, que serão acionadas a cada apresentação. Lugares frágeis que estimulam a passagem, a habitação. Situações que nascem diante do espectador. Espaços livres que atravessam estruturas fixas e determinadas. Breves oscilações na forma já conhecida, já desenhada, pintada, dançada ou interpretada e que favorecem o surgimento de novos espaços. Lugares por onde a obra se

\footnotetext{
${ }^{230}$ Texto original: "Dancers will come in every day and do pliés, and every day you have to reconnect to the idea of a plié rather than thinking you've mastered it. It's the same in conflict; it's not about having a set pattern of response, but about practicing the most basic actions of perception, expression and focus."

${ }^{231}$ Idem 119.

${ }^{232}$ Texto original: "What shaped me in the first years here was that Bill was asking us to consciously seek ways of seeing differently."
} 
especializa, toma conta e se faz no espaço. A obra respira, é organismo que encontra conexões com o entorno, se alimenta e se faz nova a cada apresentação.

Para tanto, a escuta do artista e a preparação de um corpo "sensível", que se abre às interferências do meio, parecem ser fundamentais para tal encaminhamento. Mesmo obedecendo a estruturas pré-estabelecidas, o artista precisa se movimentar livremente pelas pequenas aberturas, pausas, silêncios e trânsitos que constituem o trabalho. Para tanto, sua percepção deverá estar aberta e em contato direto com o espaço circundante e com os registros que se movimentam em seu corpo. Corpo que deve ser aqui compreendido como lugar de passagem, como campo em constante troca e transformação.

Essa abordagem que toca em fundamentos de uma educação estética se adere a "uma dimensão que depende do modo de "estar-no-mundo", do quanto se está impregnado por ações constituídas do des-aprender, perceber e reconhecer o mundo vivido que atravessa o seu corpo e o do outro." (Beth Lopes, 2010) ${ }^{233}$

\section{Interações e aderências}

No contexto de abertura das produções e dos conceitos em arte, é importante que a educação de artistas e educadores preveja interações entre campos, práticas, experimentações e pensamentos. É importante que prática e teoria sejam capaz de dinamizar campos e promover a discussão de processos artísticos em várias direções. Se teóricos que se apropriam de práticas como ferramentas ou se artistas que somam ao seu material e matéria de trabalho referenciais e conteúdos pautados em teorias, o que importa é a abertura, a troca e o livre trânsito entre saberes, como prevêem as abordagens trans ou interdisciplinares. É possível mencionar aqui a liberdade de escolha dos meios para a abordagem e para a investigação dos mais diversos objetos de estudo. A delimitação precisa entre o teórico e prático vai na contramão daquilo que se propõe a arte hoje - a construção de um ambiente que prevê a superação de dicotomias. Toda a flexibilização e abertura para novos modos de relação são fundamentais para o surgimentos e a manutenção de um campo estendido no qual a variedade de meios, materiais e estímulos favorece o exercício da arte como produção de conhecimento.

Neste contexto, a produção de William Forsythe se localiza nesse intervalo, nessa

\footnotetext{
${ }^{233}$ Texto 'Treinamento: a face e o dorso". Disponível no link:

http://www.seer.unirio.br/index.php/opercevejoonline/article/view/1442/1246. Acesso em setembro de 2015.
} 
abertura para experiências que não residem nesta ou naquela linguagem, mas que incitam a construção de vínculos e pensamentos sob uma perspectiva que aproxima arte, filosofia e matemática, por exemplo. Sua propostas são desdobramentos de ações e investigações que fundamentadas em noções conceituais e filosóficas exploram potencialidades e dinâmicas das relações entre corpo e espaço em paragens que alertam os sentidos para uma percepção ambiental que pode ser observada sob o ponto de vista de uma educação estética.

Paragens são continuações, fios que se expandem quando freio movimentos e tempos já conhecidos.

Observar sob diferentes pontos de vista não implica criar novos lugares fixos ou determinar novas categorias. Olhar sob novos ângulos é exercitar o movimento, a construção de passagens transitórias, migratórias e temporárias que se modificam de acordo com circunstâncias e complexidades nada óbvias que surgem nas relações que criamos com o mundo.

Sob esse ponto de vista, esse estudo que prevê abordagens sobre condições espaciais, é um ponta pé inicial ou um convite a uma reflexão sobre a produção de relações e pensamentos que transitam entre lugares e que possibilitam o exercício do sensível, a prática de uma educação estética que não se restringe a uma área, mas que desliza entre saberes e referentes.

Mudar tudo de lugar, transferir referências e criar novos pontos para a observação dos fenômenos são condições presentes e enfatizadas por procedimentos da arte contemporânea. Essa mudança constante de ponto de vista gera perspectivas inusitadas e a possibilidade de um deslocamento livre entre áreas e conhecimentos. Multiplicam-se os referenciais e uma malha fina passa a interligar pontos que pareciam distantes.

Uma abordagem mais demorada deste assunto requer a elaboração de um projeto de pesquisa que conte com um mapeamento de referenciais e episódios que tratem de condições e metodologias que possam auxiliar o exercício e a prática do sensível. Como incentivar a construção de campos dinâmicos que estimulam o olhar e os sentidos para saltos e sustos que confrontam o corpo com impactos físicos e ambientais? Um dado que me parece fundamental é a abordagem do espaço como instância que age no corpo, nos ossos e provoca desvios, alterações de rota e a construção de trajetos inusitados que se desenham e se apagam.

A observação de qualidades sensíveis está associada à exposição de aspectos da materialidade que desafiam o corpo e os sentidos a passagens em aberto que levam a lugares insuspeitos. Nas palavras de Manoel de Barros ${ }^{234}$ :

\footnotetext{
${ }^{234}$ Poemas publicados na revista online Bula e disponíveis no link: http://www.revistabula.com/2680-os-10melhores-poemas-de-manoel-de-barros/. Acesso em março de 2015.
} 


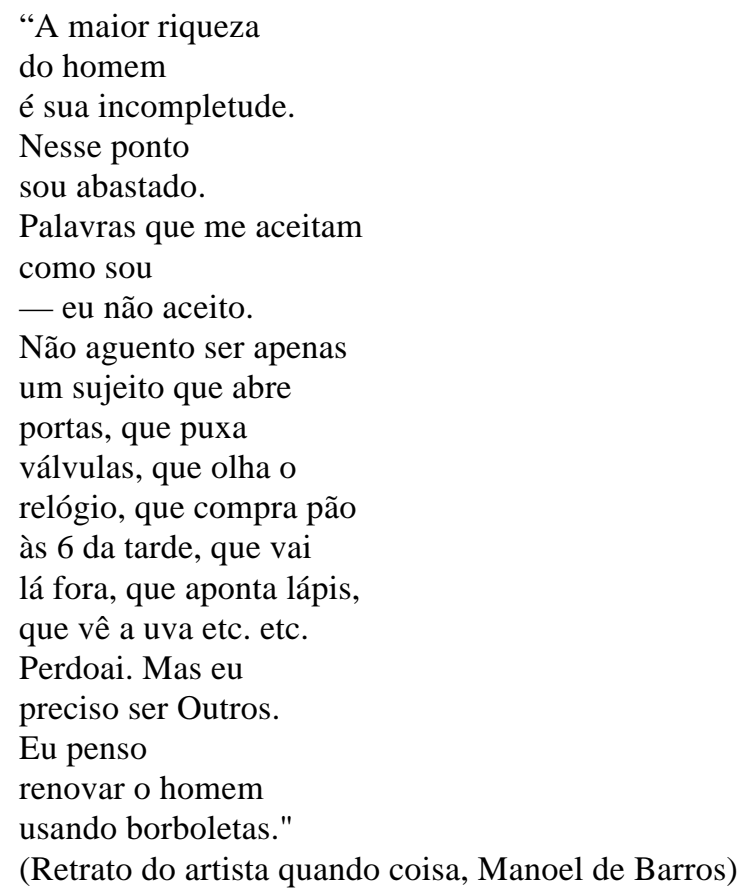

"Uso a palavra para compor meus silêncios. Não gosto das palavras fatigadas de informar. Dou mais respeito às que vivem de barriga no chão tipo água pedra sapo.

Entendo bem o sotaque das águas Dou respeito às coisas desimportantes e aos seres desimportantes. Prezo insetos mais que aviões. Prezo a velocidade das tartarugas mais que a dos mísseis. Tenho em mim um atraso de nascença.

Eu fui aparelhado

para gostar de passarinhos. Tenho abundância de ser feliz por isso. Meu quintal é maior do que o mundo.

Sou um apanhador de desperdícios: Amo os restos como as boas moscas.

Queria que a minha voz tivesse um formato de canto.

Porque eu não sou da informática: eu sou da invencionática. Só uso a palavra para compor meus silêncios.

(O apanhador de desperdícios Manoel de Barros)

"O filósofo Kierkegaard me ensinou que cultura é o caminho que o homem percorre para se conhecer. Sócrates fez o seu caminho de cultura e ao fim falou que só sabia que não sabia de nada.

Não tinha as certezas científicas. Mas que aprendera coisas 
di-menor com a natureza. Aprendeu que as folhas das árvores servem para nos ensinar a cair sem alardes. Disse que fosse ele caracol vegetado sobre pedras, ele iria gostar. Iria certamente aprender o idioma que as rãs falam com as águas e ia conversar com as rãs.

E gostasse mais de ensinar que a exuberância maior está nos insetos do que nas paisagens. Seu rosto tinha um lado de ave. Por isso ele podia conhecer todos os pássaros do mundo pelo coração de seus cantos. Estudara nos livros demais. Porém aprendia melhor no ver, no ouvir, no pegar, no provar e no cheirar.

Chegou por vezes de alcançar o sotaque das origens. Se admirava de como um grilo sozinho, um só pequeno grilo, podia desmontar os silêncios de uma noite! Eu vivi antigamente com Sócrates, Platão, Aristóteles esse pessoal.

Eles falavam nas aulas: Quem se aproxima das origens se renova. Píndaro falava pra mim que usava todos os fósseis linguísticos que achava para renovar sua poesia. Os mestres pregavam que o fascínio poético vem das raízes da fala.

Sócrates falava que as expressões mais eróticas são donzelas. E que a Beleza se explica melhor por não haver razão nenhuma nela. O que mais eu sei sobre Sócrates é que ele viveu uma ascese de mosca."

(Aprendimentos, Manoel de Barros) 
R.e.t.i.c.ê.n.c.i.a.s 
Sob uma perspectiva filosófica, social, política e estética, podemos localizar o teatro e mesmo a produção de arte atual em um intervalo no qual as mais variadas forças agem provocando o surgimento de paisagens frágeis, lugares que se apagam com o tempo.

Desde que Nietzsche, na virada do século XIX, declarou fim à moral e ao absoluto, multiplicaram-se os pensamentos e as teorias que observam a nossa realidade, as tramas sociais e os processos de produção em arte como um emaranho no qual aprendemos e descobrimos modos de nos relacionarmos com nós mesmos, com o outro e com o mundo. Muito embora ele não tenha sido o único pensador e nem o primeiro a propor novas articulações para o pensamento, suas contribuições foram fundamentais para a descentralização de referências fixos e absolutos em um contexto social e histórico ocidental pautado na estabilização de saberes e na categorização como metodologia de acesso ao conhecimento.

Hoje lidamos com os mais variadas referências e a construção de sentidos, do sujeito e de subjetividades que percorrem um caminho complexo e dinâmico no qual teóricos, artistas, cientistas e curiosos, de um modo geral, se empenham no sentido de esclarecer e fornecer instrumentos ou pistas para o mapeamento e a reflexão dos diversos elementos que compõem a paisagem contemporânea.

Transformações de paradigmas estéticos, que influenciam práticas e propostas artísticas, também alteram coordenadas que orientam a educação no contexto atual. A formação do artista inserido num terreno de hibridizações, projetos interdisciplinares e áreas que se fazem num contexto de inter-relações passa por revisões e tende a incorporar procedimentos que prevêem, muitas vezes, a sensibilização como exercício fundamental para a produção artística.

Abordagens contemporâneas sobre o evento da arte reconhecem a própria produção artística como forma de conhecimento. Fazer, agir, reagir, perceber, escutar, olhar, refazer, perder e encontrar são algumas das orientações que, conjugadas, movimentam processos de conhecimento sobre o mundo.

Um ponto de partida para tal reflexão é a compreensão da arte em seu estatuto ontológico privilegiado. A arte, em uma das suas possíveis abordagens, apresenta-se como acesso a uma percepção fundamental e a um conhecimento que se dá em sua própria ação. Ação esta que coincide com uma experiência estética, quando um terreno sem fronteiras favorece acessos imprevistos e estímulos inusitados nas relações do sujeito com o ambiente circundante.

Algumas práticas de formação e preparação do artista procuram sensibilizar e orientar o 
corpo para aberturas e conexões com o entorno. Afinar a sensibilidade, a percepção e os sentidos são algumas das orientações fundamentais num contexto que pretende engajar o sujeito em suas ações e produções. Exercitar o corpo em seus diálogos e negociações com o meio, como um espaço que se molda na relação.

As ações do corpo humano, o encontro de corpos, a ativação da arquitetura, de objetos que animam o espaço, a percepção em órbita, a desestabilização dos sentidos e a criação de novas relações são algumas das premissas desse lugar da arte por onde transitam diferentes práticas artísticas e considerações sobre a experiência estética. Talvez transitem por aí as inquietações das vanguardas do século XX que preconizavam uma arte sem arte, uma arte sem categorias e sem as delimitações que simplificam complexidades fundamentais para a produção dos fenômenos artísticos. A arte se apresenta, deste modo, como um amplo campo de conhecimento e prática no qual as linguagens se conversam e o pensamento se faz em movimento, enquanto descobre novos acessos e trajetos.

A observação dessas características e qualidades dinâmicas gera investigações que tratarão do campo perceptivo do espectador, como olhar e presença física, que será convidado às mais variadas ações e experiências temporais.

O espectador é agora presença temporal que participa de projetos que instauram situações de paragens e suspensões que desafiam a sua percepção. Suas experiências coincidem, de algum modo, com o susto, com o instante em que os canais perceptivos se confundem, se movem e constroem novas perspectivas e pontes de acesso ao mundo. Um tempo distinto daquele cotidiano surge nesses momentos de suspensão, nesses intervalos nos quais o corpo oscila e se instauram novos sentidos.

\section{William Forsythe em linhas aderentes}

As investigações espaciais propostas por William Forsythe podem ser observadas a partir de um simples desenho que esboça as dinâmicas fundamentais que orquestram e fundamentam seus trabalhos:

Um ponto que se desloca continuamente e que não distingue centro e periferia. Um ponto que se multiplica em linhas de força que jogam o olhar para cantos, dobras, que acionam o aparecimento e o desaparecimento de ângulos, intensidades, alturas e variações que rabiscam o espaço e criam um emaranhado de rastros e memórias em movimento. Trajetos que ativam a percepção para detalhes que já não passam desapercebidos. Múltiplos rabiscos 
que ora tocam o chão, ora o ar, ora o corpo e ora o olhar. Gestos que prolongam o corpo e que esticam o tempo. As propostas de Forsythe desenham linhas, geometrias, esboçam ambientes, estão presente em objetos, arranjos espaciais, interagem com estímulos e com as interferências da arquitetura, são escuta e a produção de paisagens que vemos e nos vêem.

O estudo de qualidades e variações espaciais acontece nas trocas, contatos e tramas que ligam corpo e espaço, um entrelaçado no outro como um amplo desenho no qual se costuram aspectos visíveis e invisíveis, intensidades e vibrações. Um corpo que se espalha pela planície ao mesmo tempo em que é devorado pelos declives entre as montanhas.

A produção de Forsythe é ampla, descentralizada e pode ser analisada sob as mais diversas perspectivas. A investigação de limites, de possibilidades para o corpo, de relações, a construção de linguagens tendo a sua disposição diferentes recursos, materiais e as múltiplas abordagens que se somam ao seu repertório. A vertigem, a alteração de eixos e o surgimentos de ações que negociam com o tempo, com condições ambientais e a multiplicação de dobras, de pontos de contato que ampliam pontos de vistas de fenômenos limitados por suportes e funções determinadas. Quanto mais contato com textos e materiais sobre a atuação de Forsythe, mais percebe-se variações possíveis de observação de seus trabalhos.

Seu interesse pelo movimento, pelas possibilidades do corpo no espaço e pelas relações possíveis entre estímulos ambientais e deslocamentos físicos amplia sua zona de ação e faz com seus trabalhos sejam processos em constante transformação e em diálogo com múltiplas áreas de conhecimento. $\mathrm{O}$ olhar para o entorno, a percepção de sutilezas e a experiência de tempos que suspendem o ritmo cotidiano são alguns dos pontos de partida da ampla e descentrada atuação de Forsythe.

$\mathrm{O}$ artista se interessa menos pela localização de sua produção e mais pelas dinâmicas e variações possíveis do pensamento. As leituras dos seus trabalhos são também múltiplas e são comuns as análises que pontuam o seu interesse pela transformação dos parâmetros do balé e da dança. Entretanto, as considerações de Forsythe confirmam seu interesse por fórmulas em aberto, por indeterminações e por traços e linhas coreográficas que pontuam o espaço como ambiente de ressonância no qual corpo, percepção, linguagens e texturas são construídas. A relação entre possibilidades, materiais, corpo e conhecimentos gera trabalhos nos quais noções como dança e coreografia aparecem esticados ou mesmo distanciados das ideias e conceitos tradicionais. Muitos críticos e teóricos inserem suas práticas no contexto do teatro experimental e dão ênfase à pluralidade de suas ações que invertem, estendem, contorcem e alteram referenciais tradicionais de observação da dança, do balé e da prática em arte.

Das investigações coreográficas, da regra e da exceção, dos procedimentos e das 
propostas que dinamizam vínculos entre corpo e espaço, Forsythe dá destaque a aspectos instalativos que deflagram uma sucessão de movimentos e aberturas que multiplicarão o olhar, os sentidos e as possibilidades de relação em suas propostas. Se os pontos e as linhas do balé indicaram os primeiros esboços que alteraram rotas e formatos previsíveis, a investida em dinâmicas, flutuações, suspensões, acelerações, fragmentações e sobreposições favoreceu uma investigação contínua e extensa sobre o fenômeno artístico, sobre as possibilidades coreográficas, sobre limites institucionais, sobre a produção em arte sem a orientação de um rótulo, de uma categoria e sobre a percepção que gera descobertas de pesos, massas e produz espaços frágeis e temporários.

As práticas de Forsythe fornecem material para o aprofundamento de questões que me parecem fundamentais para o pensamento sobre da arte no panorama atual. A expansão de conceitos, a sacudida na percepção e a variação de perspectivas propostas por Forsythe estimulam o olhar sobre a arte como um campo de produção de pensamentos que acontece entre referenciais práticos e teóricos. O pensamento é gerado a partir de colisões, coalizões, de acasos, leituras, olhares em vibração e passos contínuos que tocam os pés, as pernas e os músculos. O deslocamento de eixos, a variação do corpo, a mudança de referenciais e a sensibilização dos sentidos promove a abertura de conceitos e substitui afirmações duras por colocações móveis e provisórias. As propostas de Forsythe são facilitadoras e passagens que colaboram para a composição do escopo fundamental desta pesquisa. Não são fim, mas meios de acessos ou linhas orientadoras de um pensamento sobre dinâmicas e interações espaciais que podem ser úteis ao pensamento e à prática em arte, assim como ao olhar curioso que investiga o mundo como pela primeira vez.

Talvez a maior contribuição de Forsythe esteja no cruzamento de pensamentos que colocam o corpo e as delimitações institucionais em órbitas imprevistas e irregulares. Aquilo que é ou pode vir a ser o balé, a dança, o teatro e a arte localiza-se em um terreno volátil e efêmero no qual os sentidos e os conceitos se reorganizam constantemente e aberturas são geradas. A observação do balé sob o ponto de vista dos Objetos Coreográficos imprime à dança um caráter processual no qual o corpo, independentemente da categoria de artista ou público, experimenta saltos e variações que suspendem sentidos instituídos e impostos por regulamentações que produzem sempre os mesmos pensamentos e as mesmas perspectivas.

Seus trabalhos assumem as variações e experiências temporais, a descentralização do olhar, a multiplicação de pontos de vista e a construção de percursos instáveis e linhas frágeis que convidam o espectador a passeios por formações temporárias e suspensões. Suas propostas tratam da materialidade e da condição transitiva que se manifesta na forma e nas 
composições espaciais. O corpo aparece como estrutura óssea, como tecido relacional e como expansão que compõe paisagens efêmeras. $\mathrm{O}$ espaço se manifesta no apagamento constante de traços que definem objetos, coisas e lugares. Essas condições evidenciam aspectos relacionais e dialogam com questões presentes no contexto de movimentos de vanguarda, como o Minimalismo e o Neoconcretismo.

William Forsythe trabalha na expansão e na investigação de dinâmicas para além de normas, modelos ou padrões instituídos. Ele trabalha na amplitude do evento e desloca seu interesse da apresentação para o acontecimento. Sua produção coincide com a investigação e o desdobramento de questões referentes ao fenômeno da arte. Se em algum momento o seu ponto de partida foi o balé, como estrutura, o seu ponto de chagada é o deslocamento por um espaço instável no qual uma ampla variedade de experimentações ampliam sua zona de ação e solicitam o pensamento, em incursões pelo espaço, como agente e produtor de novas relações.

Há, em suas propostas e nos trabalhos que foram discutidos nesta pesquisa, uma abordagem que dinamiza perspectivas, que articula múltiplas camadas e intensidades, que desmonta paisagens já conhecidas e promove rodopios do corpo em diferentes níveis e qualidades. Esse conceito que desenha o terreno e aponta as condições deste objeto de estudo coincide com a noção de Heterotopia do filósofo francês Michael Foucault.

Parece-me que mais do que insistir na ideia do balé ou da dança, o que Forsythe propõe se manifesta em sua concepção de coreografia. Não há o intuito da desmontagem ou da desconstrução como método para a rearticulação de elementos, mas antes o desejo de mudar as coisas constantemente de lugar e observá-las sob os mais variados pontos de vista. O cruzamento de referenciais parece condizer mais com a prática e com os propósitos de Forsythe do que a tentativa de se instaurar um novo referencial para a dança ou mesmo para o balé. É claro que sua atuação, por ter se baseado durante anos em referenciais de partituras do balé clássico, nos leva a perceber mudanças de abordagem radicais no que diz respeito aos padrões que detectamos na prática tradicional do balé. Entretanto, as mudanças constantes de perspectiva e as suas incursões por diferentes campos, como a matemática, a física e a filosofia, por exemplo, atestam que os deslizem de um lugar para o outro parecem compor um campo de atuação que não procura paradeiros, mas antes impulsos que provocam o olhar para a descoberta de lugares desconhecidos da memória. Sim, passamos a ver o balé sob outras perspectivas, mas passamos a ver também a dança e as artes sob um prisma oscilatório e descentralizado no qual múltiplas camadas se sobrepõem na produção de paisagens frágeis e efêmeras.

E é sob essa perspectiva que proponho um olhar sobre a condição do teatro 
contemporâneo que aparece nos intervalos, nas entrelinhas que acionam redirecionamentos e reconfigurações espaciais. Passear por novos tempos, experimentar novos pesos, suportes, apoios, oscilar, variar de altura e reposicionar os sentidos são alguns dos indicativos da inauguração de espaços teatrais.

A pluralidade de projetos e ações artísticas no contexto atual nos levar a pensar o teatro e as artes, de um modo geral, como um campo de ação que supera os limites das linguagens e das especificidades deste ou daquele domínio de conhecimento. A expansão prevê a mobilidade e o cruzamento de saberes.

\section{Linhas finais}

Enquanto escrevo as páginas finais desta pesquisa acontece uma exposição em Dresden, na Alemanha, que reúne trabalhos que evidenciam a presença de desenhos como gestos que são disparados por interações entre corpo e espaço. A exposição "DISEGNO. The art of drawing for the 21 st century" apresenta o desenho no século XXI como manifestação presente também na dança, na filosofia, na literatura e na fotografia, por exemplo. O desenho se espalha, atravessa frestas, percorre rotações e condensa impulsos e aspectos que cruzam áreas e linguagens possibilitando rearticulações para o corpo, para o olhar e para o pensamento. O desenho aparece em linhas, pontilhados, rabiscos, diagonais difusas, na intersecção do olhar, na revelação do vazio e nas incalculáveis curvas e tramas geram mudanças de perspectiva e a produção de conhecimento.

O desenho, mencionado logo no início deste trabalho, como orientação que organiza e cria sustos para os sentidos, aparece na exposição Disegno a partir de trabalhos de artistas que condensam em linhas e gestos sobre a superfície ideias, pensamentos, trajetos percorridos pelos sentidos e pelos olhos que se aderem à paisagem. Entre os artistas que participam da exposição, que não são exclusivamente das artes visuais, está William Forsythe. A relação da dança com o desenho, no trabalho presente nesta exposição, evidencia uma pesquisa de rotas e pensamentos que transitam entre linguagens e não prevêem a escolha de uma área específica de atuação. As relações atravessam os suportes e dão ao corpo a possibilidade de criar espaço nas mais diversas direções e partir dos mais variados recursos.

Dança, coreografia, filosofia e os mais variados campos de conhecimento se encontram nesse emaranhado de pensamentos que se materializam em linhas, pontos dispersos, corpos e impressões que aparecem no trabalho de Forsythe nesta exposição. 
E são essas incursões espaciais que ativam e liberam a arte da repetição de figuras, imagens e padrões já conhecidos e a insere em um contexto de criação de paisagens improváveis e imprevisíveis que produzem novos modos de vincular corpo e espaço.

Neste momento da pesquisa visualizo o que pode ou poderia vir a ser um desenho livre. Um desenho que transita entre referenciais, que investiga possibilidades, que não se impõe como verdade, mas que gera processos dialógicos em suas ambulações pelo mundo.

Desenho quando jogo meu olhar para o fundo da paisagem, quando diluo meus pensamentos e permito que novas formações se instaurem nesse lugar precário entre meus sentidos e as matérias do mundo. Formações frágeis que logo se transformarão em algo que não conheço e que não saberia nomear. A porta aberta para o susto, a iminência do acontecimento, a estante que se move e altera a posição de autores, referências, livros e anotações. O caos que costura novas constelações, que provoca o aparecimento de novos acessos e os amontoados que interditam passagens conhecidas. $\mathrm{O}$ tremor, o tempo incerto, o acaso, a organização do tempo e do espaço sob novas medidas.

A relatividade das medidas, dos padrões e das coisas que definem o mundo se rearticulam diante do olhar, diante das relações escorregadias que eu crio com o mundo.

\section{Desacelerar}

Um passo atrás, o instante em que os sentidos e as falas cotidianas desaparecem. Escalar paisagens desconhecidas é acionar relações imprevistas. É possibilitar ao corpo o acesso pela saída, pelas entradas laterais ou radicalizar na invenção de escaladas que ativam os sentidos para além daqueles que cabem em estruturas discursivas conhecidas.

A produção desta pesquisa contou com mapas, muitos mapas, passagens em aberto e o exercício de desenhos trepidantes que alavancaram pensamentos que confundiam interações entre referenciais físicos e teóricas.

O percurso de uma pesquisa coincide com a construção de uma complexa rede de pensamentos que se manifestam nos interstícios entre referenciais práticos e teóricos. Nenhuma pesquisa, por mais acadêmica e científica que seja, é um campo teórico tão fechado que não respire e não reinvente o meio onde ela acontece.

O processo de imersão, exige braçadas longas, pausas, estados de atenção e a dissolução do corpo ao material que está sendo investigado. Toda abstração reverbera nos ossos, nas tensões e relaxamentos que se somam ao processo de criação. 
Iniciei essa pesquisa com um trajeto que previa atravessar o atlântico e aprender um novo idioma. Uma língua nova pressupõe pinceladas suaves e demoradas, a apreensão de novas cores e a descoberta de tonalidades e alturas que se aderem ao corpo com o tempo.

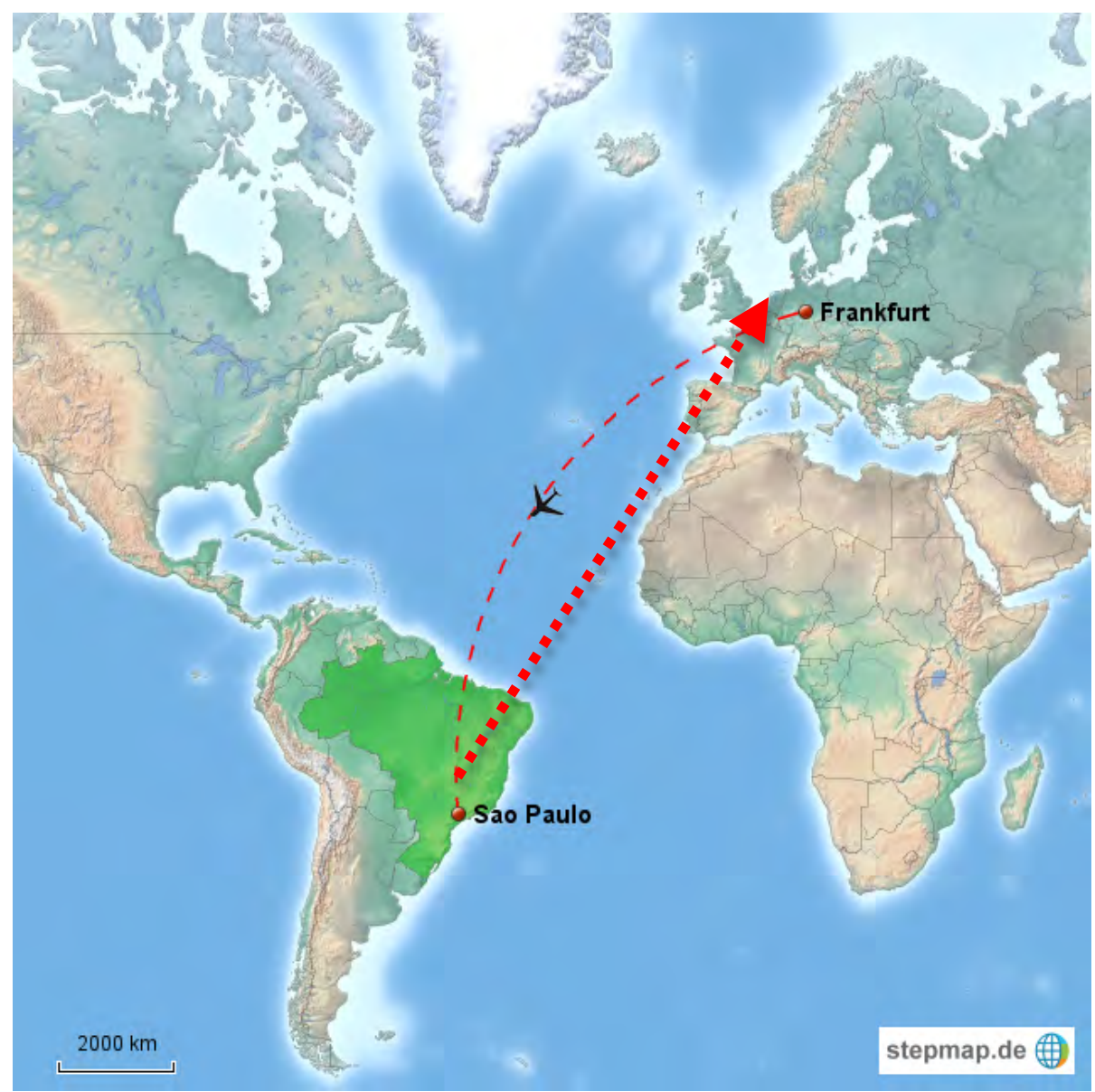

Tracei o percurso. Criei uma linha no mapa e interliguei Brasil e Alemanha. O oceano atlântico como matéria densa e extensa que aproxima países, cidades, ruelas, pontes e rios que compõem paisagens frágeis. E é nessa colagem que ora soma e ora subtrai que eu apareço interligando pontos que fazem oscilar meus ângulos de observação. Um jogo de coincidências, circunstâncias e acasos no qual apareço e desapareço como um barco que avisto por detrás das ondas grandes do mar.

Desenhar e apagar, ser corpo e lugar de memórias e impressões sobre o mundo e sobre as indeterminações de mim mesma. Aprender que os verbos cabem também no finais das frases e que algumas palavras podem ser mais precisas e soar melhor em outros idiomas. Descobrir que lugares são misturas feitas de afetos, de intervalos, vigas, calçadas de pedra, memórias, projetos, cheiros e sons que só sabemos quando o corpo entra em conflito, quando 
os sentidos negociam e quando o olhar desvia dos destinos comuns.

Precisei mudar de lugar, traçar percursos que contavam com novas organizações e sensações geográficas. Foi preciso apagar as trilhas já conhecidas e viajar por novos ângulos que me apresentaram aos poucos vestígios dos ambientes que eu intuía no início deste trabalho.

Antes de folhar livros, selecionar textos e grifar parágrafos, precisei assimilar novos ângulos e aprender a me deslocar em outro ritmo e entre variações desconhecidas. Foi preciso aprender que linhas, paisagens, arquiteturas, ambientes e demais formações espaciais contam com qualidades transitórias e indeterminadas que superam os limites impostos por margens e fazem emergir o improvável.

Uma pausa. Um respiro e o mundo de ponta à cabeça. É preciso balançar, mexer e provocar colapsos para que novos olhares se manifestem, para que as formas se apresentem como são: transitórias e desvinculadas de um ponto de fuga fixo e opressor de fragilidades e tremores que acionam as linhas que desenham o processo no qual estamos vinculados: a vida.

Mergulhos, imersões por paisagens aéreas, as folhas de papel rabiscadas, as anotações amassadas, os textos falados em voz alta, os burburinhos do outro lado da calçada, a movimentação das rochas, o som da grama nascendo, a manifestação do nascimento do mundo em chutes e torções experimentadas no útero que avançam por paisagens frágeis e desconhecidas que começam a ser produzidas na inauguração da vida de um coração extenso, transitivo e temporário - como é esse que liga todos os pontos do mapa para depois apegar e começar tudo de novo. 


\section{Paisagem}

As grandes paisagens têm, todas elas, um caráter visionário. A visão é o que do invisível se torna visível [...] a paisagem é invisível porque quanto mais a conquistamos, mais nela nos perdemos. Para chegar à paisagem, devemos sacrificar tanto quanto possível toda determinação temporal, espacial, objetiva; mas este abandono não atinge somente o objetivo, ele afeta a nós mesmos na mesma medida. $\mathrm{Na}$ paisagem, deixamos de ser seres históricos, isto é, seres eles mesmos objetiváveis. Não temos memória para a paisagem, não temos memória, nem mesmo para nós na paisagem. Sonhamos em pleno dia e com os olhos abertos. Somos furtados ao mundo objetivo mas também a nós mesmos. É o sentir. (STRAUSS, 2006 apud BESSE, Jean-Marc) 
Referências bibliográficas

AUSTIN, John Langshaw. Quando dizer é fazer. Palavras e ação. Tradução de Danilo Marcondes de Souza Filho. Porto Alegre: Artes Médicas, 1990.

ARGAN, Giulio Carlo. Arte Moderna. São Paulo: Companhia das letras, 1992. 1993.

BACHELARD, Gaston. A Poética do Espaço. São Paulo: Editora Martins Fontes,

BARROS, Manoel. Poemas publicados na revista online Bula e disponíveis no link: http://www.revistabula.com/2680-os-10-melhores-poemas-de-manoel-de-barros/

BERGSON, Henri. Matéria e Memória: Ensaio sobre a relação do corpo com o espírito. São Paulo: Editora Martins Fontes, 1999.

BESSE, Jean-Marc. Ver a Terra. Seis ensaios sobre a paisagem e a geografia. Sa o Paulo: Perspectiva, 2006.

BISHOP, Claire. Artificial Hells. Participatory art and the politics of spectatorship. Londres: Verso, 2012.

BISHOP, Claire. Instalation Art. Londres: TATE Publishing, 2005.

BISHOP, Claire. Participation. Inglaterra: Whitechapel Gallery e MIT Press, 2006.

BLOOR, David. Wittgenstein. Rules and Institutions. Londres: Routledge, 2002.

BRANDSTETTER, Gabriele \& KLEIN, Gabriele (Org). Dance (and) Theory. Transcript: Bielefeld, Alemanha, 2013.

BRANDSTETTER, Gabriele \& WIENS, Brigit (Org.). Theater ohne Fluchtpunkt. Das Erbe Adolphe Appias: Szenographie und Choreographie im zeitgenössichen Theater. Theater without vanishing points. The Legacy of Adolphe Appia: Scenography and Choreography in Contemporary Theatre. Berlim: Alexander Verlag Berlin, 2010.

BRANDSTETTER, Gabriele. Defigurative Choreography. From Marcel Duchamp to William Forsythe. Drama Review, Vol.42, no 4, 1998, 37-55.

BRASIL, Giselly. Trajetórias do espectador nas travessias de Lygia Clark e Pina Bausch. Dissertação de mestrado. Florianópolis. UDESC, 2011.

BRITO, Ronaldo. Neoconcretismo. Vértice e ruptura do projeto construtivo brasileiro. São Paulo: Cosac Naify, 1999.

BORRIAUD, Nicolas. Estética relacional. Buenos Aires: Adriana Hidalgo Editora, 2008 .

CABALLERO, Illeana Diéguez. Escenarios Liminales: teatralidades, performances y política. Buenos Aires: ATUEL, 2007. 
CARLSON, Marvin Carlson. Teorias do Teatro. São Paulo: Editora UNESP, (1995).

CÍCERO, Antonio. Finalidade sem fim. Ensaios sobre poesia e arte. Kant, Greenberg e o modernismo. Cia das Letras, 2005.

CIOTTI, Naiara. O professor-performer. Natal, RN. EDUFRN, 2014.

CLARK, Lygia, GULLAR, Ferreira \& PEDROSA, Mário. Lygia Clark. Arte Brasileira Contemporânea. Rio de janeiro: edição FUNARTE, 1980.

COHEN, Renato. Performance como Linguagem. São Paulo: Editora Perspectiva, 1989.

CONTE, Jaimir. O início: Sexto Empírico e o ceticismo pirrônico, 2010. http://revistacult.uol.com.br/home/2010/03/o-inicio-sexto-empirico-e-o-ceticismo-pirronico/.

DANTO, Arthur. A transfiguração do lugar comum: uma filosofia da arte. São Paulo, Cosac Naify, 2010.

DELEUZE, Gilles. A Dobra: Leibniz e o Barroco. Campinas, SP: Papirus, 1991.

Diferença e Repetição. Rio de Janeiro: Graal, 2006.

DEWEY, John. In Os Pensadores (Experiência e Natureza). São Paulo: Editora Abril Cultural, 1974.

in Os Pensadores (Experiência Estética). São Paulo: Editora Abril Cultural, 1980.

DIDI-HUBERMAN, Georges. O que vemos o que nos olha . São Paulo: Editora 34, 1998.

DUARTE, Cláudia. Marcel Duchamp, olhando o Grande Vidro como interface, Rio de Janeiro, Rios Ambiciosos, 2000, pp.42/43

DUARTE Jr., João - Francisco. O Sentido dos sentidos. A educação dos sentidos. Criar Edições LTDA: Curitiba, Paraná, 2006.

EVERT, Kerstin. DanceLab: Zeitgenössischer Tanz und Neue Technologien. Königshausen \& Neumann: Würzburg, 2003.

FAVARETTO, Celso. A Invenção de Hélio Oiticica (1992), $2^{a}$ ed.. São Paulo: Editora da Universidade de São Paulo, 2000.

FERNANDES, Silvia. Teatralidade e textualidade. A relação entre cena e texto em algumas experiências de teatro brasileiro contemporâneo. Sílvia Fernandes, Artefilosofia, Ouro Preto, n.7, p. 167-174, out.2009

Repertório, Salvador, no 16, p.11-23, 2011.

FLORES, Vitor. Minimalismo e Pós-Minimalismo Forma, Anti-forma e Corpo na 
Obra de Robert Morris, Vitor Flores, 2007. http://revistacult.uol.com.br/home/2010/03/oinicio-sexto-empirico-e-o-ceticismo-pirronico/.

FÉRAL, Josette. Acerca de la teatralidad. Argentina, Buenos Aires: Ediciones Nuena Generación, 2003.

FISCHER - LICHTE, Erika. The transformative power of performance. A new aesthetics. Routledge, New York, 2008.

FOUCAULT, Michael. De outros espaços. Traduzido (com base no texto publicado em Diacritics; 16-1, Primavera de 1986) por Pedro Moura. Conferência proferida por Michel Foucault no Cercle d'Études Architecturales, em 14 de março de 1967

São Paulo : Martins Fontes, 1999.

As palavras e as coisas: : uma arqueologia das ciências humanas.

FREID, Michael, Absortion ans Theatricality: painting and Beholder in the age of Diderot, Chicago and London, The University of Chicago, 1980.

University of Chicago Press, 1998.

Art and Objecthood: essays and reviews, Chicago and London,

Arte e Objetividade. Trad. Milton Machado. Revista do Programa de Pós-Graduação em Artes Visuais EBA, UFRJ, Rio de Janeiro, 2002.

GLUSBERG, Jorge. A arte da performance. São Paulo: Perspectiva, 2009.

GULLAR, Ferreira. Teoria do Não-Objeto. In: Experiência Neoconcreta: momentolimite da arte. São Paulo: Cosac Naify, 2007.

GREGG, Melissa \& J. SEIGWORTH, Gregory. The Affect Theory Reader. Londres: Duke University Press, 2010.

HARDT, Yvonne \& STERN, Martin (org). Choreographie und Institution. Zeitgenössicher Tanz zwischen Ästhetik, Producttion und Vermittlung. Bielefeld, Alemanha: Transcript, 2011.

HARRISON, Charles \& WOOD, Paul (org.). ART in Theory (1900-2000): An Anthology of Changing Ideas. Malden, MA: Blackwell Pub, 2003.

HIRSCH, Nikolaus. On Boundaries. Nova Iorque: Lukas \& Sternberg, 2007.

HARRISON, Charles \& WOOD, Paul (org.) Textos Robert Morris. Art in Theory 19002000: An Anthology of Changing Ideas. Paperback, 23 Sep 2002.

KLEE, Paul. Sobre a arte moderna e outros ensaios. Rio de Janeiro: Jorge Zahar, 2001.

KRAUSS, Rosalind. A escultura no campo ampliado. Revista do curso de especialização em História da Arte e Arquitetura. PUC-Rio. Ano 1984 (87-93).

LAÇAVA, Maria Cecília P. em Reflexões sobre Laban, o mestre do movimento. Org: 
Maria Mommensohn e Paulo Petrella. Sao Paulo: Summus, 2006.

LEIGH, Susan. Move - choreographing you : [art and dance since the 1960s], London : Hayward, 2010.

LEFREBVRE, Henri. Rhythmanalysis. Space, Time and Everyday Life. Bloomsbury Academic: UK/ USA, 2013.

The Production of Space. Backwell Publishing, UK, 1991.

LEMANN, Hans-Thies. Teatro pós-dramático. Editora Cosac naify: São Paulo, 2007.

LEPECKI, André. Agotar la danza. Performance y política del movimento. Menú de Comunicació: Espanha, Centro Coreográfico Galego / Universidade de Alcalá, , 2008.

Moving as Thing: Choreographic Critiques of the Object.

OCTOBER Magazine, 2012, 75-90.

LOPES, Beth. Treinamento: a face e o dorso em "Nossa experiência com a SITI Company", Claudia Mele (FAV), Beth Lopes (USP) e Matteo Bonfitto (UNICAMP).

2012.

Coreopolítica e Coreopolícia. ILHA vol.13, no1, 41-60, (2011),

MERLEAU-PONTY, Maurice. Fenomenologia da Percepção. São Paulo: Editora Martins Fontes, 1999. 1992.

MILLIET, Maria Alice. Lygia Clark: Obra e Trajeto. São Paulo: Editora EDUSP,

MORRIS, Robert (em) Art in Theory 1900-2000: An Anthology of Changing Ideas. Charles Harrison \& Paul Wood (org.). Paperback, 23 Sep 2002.

Notes on dance - The Tulane Drama Review. Vol. 10, No. 2 (Winter, 1965), pp. 179-186. Publicado por MIT Press.

O'DOHERTY, Brian. No Interior do Cubo Branco. A Ideologia do Espaço de Arte. São Paulo: Martins Fontes, 2002.

OITICICA, Hélio. Aspiro ao Grande Labirinto. Rio de Janeiro: Editora Rocco, 1986.

de Janeiro: Beco do Azougue, 2009.

OSORIO, Luiz Camillo. Razões da crítica. Jorge zahar editor, RJ.

A política das artes e/ou a apropriacão institucional: a 
partir de alguns casos com os parangolés de Hélio Oiticica, ArteFilosofia, Ouro Preto, no17, dezembro de 2014.

OTTONI, Paulo, "John Langshaw Austin e a visão performativa da linguagem.”, 2002. http://www.scielo.br/scielo.php?pid=S0102-44502002000100005\&script=sci_arttext\#nt

PHELAN, Peggy. A Ontologia da Performance. Representação sem produção. Revista de Comunicação e linguagens, n.24. 1997. Lisboa: Edição Cosmos.

PETRELlA, Paulo e MOMMENSOHN, Maria (org.). Reflexões sobre Laban, o mestre do movimento. Sao Paulo: Summus, 2006.

RAMOS, Luiz Fernando. Teorizações sobre a mimesis e o espetáculo - Da similaridade à diferença e de volta à repetição. 2012, SP.

O Projeto Scene de Gordon Craig: história aberta à revisão. Rev. Bras. Estud. Presença, Porto Alegre, v. 4, n. 3, p. 443-462, set./dez. 2014.

RANCIÈRE, Jacques. A partilha do sensível: estética e política. São Paulo: EXO experimental org; 2005.

RAUNER, Gaby von. (org.). William Forsythe - Tanz und Sprache. Brandes und Apsel, 1993, Frankfurt.

REBENTISCH, Juliane. Aesthetics of Installation Art. Berlim: Sternberg Press, 2012.

REISS, Julie H. From Margin to Center: The Space of Installation Art. Inglaterra: MIT press, 2001.

RILKE, Rainer Maria. Cartas a um jovem poeta \& A canção de amor e de morte do porta-estandarte Cristóvão Rilke. São Paulo, Globo, 2011.

RUFFORD, Juliet. Theatre \& architecture. Inglaterra: Palgrave, 2015.

SCHERCHNER, Richard. Environmental Theater. New, expanded ed. Applause Theatre \& Cinema Books. Roundhouse Publishing Ltd., UK, 1994.

$2006 / 2007$.

Performance Studies: an introduction. Routledge, UK,

SIEGMUND, Gerald. Abwesenheit: Eine performative Ästhetik des Tanzes. Transcript Verlag, Bielefeld, 2006.

Verlag, Berlin, 2004.

(org.) William Forsythe, Denken in Bewegung. Henschel

Recht als Dis-Tanz: Choreographie und Gesetz in William Forsythe Human Writes. Forum Modernes Theater, 2007, 75-95. Gunter Narr, Tübingen. 
$2001, \overline{72-74}$

Choreographic Thinking. Revista ballet-tanz, Yearbook,

SPIER, Steven (edit.). William Forsythe and the practice of choreography - It starts from any point. Routledge, 2011.

Publicações em revistas, edições especiais e textos disponíveis na internet:

Suspense. William Forsythe. Catálogo de exposição. Colaboração Marcus Wiesbeck. Instituto Ursula Blicke, Kraichtal, 17 de maio - 29 de junho, 2008.

William Forsythe. Choreography and dance. An International Journal Volume 5 Part 3. Editor: Senta Driver. Publicado pela editora Routledge, 2004.

Starting Points \& Aspirations. Motion Bank: The Forsythe Company, 2013. Schmidtstraße, 12. 60326. Frankfurt am Main. www.motionbank.org

Bill's universe. Revista Ballet-Tanz. Das Jahrbuch. 2003/04

\section{Dissertações de mestrado e Teses de doutorado:}

Tese de doutorado "Audio-Visual Stress: Cognitive Approaches to the Perceptual Performativity of William Forsythe and Ensemble", de Freya Vass-Rhee, 2011.

Disponível no link: http://escholarship.org/uc/item/24q5c71p

Tese de doutorado "Curso de desenho por correspondência", de Andrea Paula Parreira Tavares, 2005, SP.

Disponível no link:

www.teses.usp.br/teses/disponiveis/27/.../AndreaPaulaPereiraTavares.pdf

Dissertação de mestrado: "Canteiro de obras, deriva sobre uma cidade-pesquisa habitada por práticas artísticas no espaço público”, de Brígida Campbel, 2008, MG.

Disponível no link:

https://www.ufmg.br/online/arquivos/anexos/Brigida_Campbell.pdf.pdf.

\section{Entrevistas e matérias online:}

Entrevista concedida na ocasião da estreia do trabalho Heterotopias na Coréia do Sul. Link: http://www.koreaherald.com/view.php?ud=20130410000930

http://www.smh.com.au/articles/2004/07/06/1089000148669.html?from=storyrhs, por Alan 
Riding em 7 de Julho 2004. Acesso: setembro de 2015.

Gerald Siegmund, 2009. texto "Spaces to Explore: Heterotopia by William Forsythe". Disponível no link: http://archive.kfda.be/projects/projects/2009/heterotopia/more.

"William Forsythe on Foucault's 'space of otherness'

Celebrated American choreographer makes Korean stage debut with 'Heterotopia'" -

Por Claire Lee

Entrevista disponível no link: http://www.koreaherald.com/view.php?ud=20130410000930.

Publicada em 10.04.2013.

"Performatividade", matéria publicada na revista Cult.

Disponível no link: http://revistacult.uol.com.br/home/2013/11/o-percurso-daperformatividade/. Acesso em outubro de 2015.

Texto "dance geometry (forsythe)" - Conversa entre Forsythe and Kaiser gravada em 1998 e publicada em Performance Research, v4\#2, Summer 1999.

disponível no link: http://openendedgroup.com/writings/danceGeometry.html

Spatial Improvisation for Architects. Gray Read

http://architecture-performance.blogspot.de/2011/02/spatial-improvisation-for-architects.html.

Acesso em: abril de 2015.

Curador Luiz Camillo Osório comenta Relações entre arte, política e mercado. Matéria de Marcos Augusto Gonçalves. publicada no dia 08/03/2015 na Ilustradísssima. Disponível no link: http://www1.folha.uol.com.br/ilustrissima/2015/03/1598685-curador...illo-osoriocomenta-relacoes-entre-arte-politica-e-mercado.shtml.

Acesso em maio de 2015.

\section{Artigos, websites e textos:}

http://www.wexarts.org/ex/forsythe/

William Forsythe: Transfigurations exhibition web page. April 2009

Erin Manning: Artigo "Prepositions for the Vergue - William Forsythe's

ChoreographicObjects". Inflexions No.2 "Nexus" (December 2008).

www.inflexions.org

Texto "Art and Objecthood" traduzido como "Arte e objetividade" e publicado na Revista do Programa de Pós-Graduação em Artes Visuais - EBA - UFRJ - 2002. Tradução Milton

Machado.

Entrevistas Forsythe:

William Forsythe dances to a new tune, por Laura Cappelle.

http://www.ft.com/cms/s/0/af9fb9ec-b5d7-11e4-a577-00144feab7de.html,

\section{Websites:}


http://www.williamforsythe.de

http://www.scielo.br/scielo.php?pid=S1678-53202011000100004\&script=sci_arttext

http://www.itaucultural.org

http://www.heliooiticica.org.br

Vídeos:

Encontro com William Forsythe - Bienal de Dança de Veneza de 2012

( Dance Biennale 2012 - A meeting with William Forsythe)

https://www.youtube.com/watch?v=J14qmjO2HNI

Entrevista - William Forsythe e Brock Labrenz

(Dance Biennale 2012 - William Forsythe \& Brock Labrenz (interview))

https://www.youtube.com/watch?v=wb9QNghklPk

Trabalho de Forsythe "Nowhere and Everywhere at the Same Time, No. 2 (2013)" , no Museum Folkwang, em Essen, Alemanha.

https://www.youtube.com/watch?v=59QRpcLgPOQ

Filme da exposição The Fact of Matter, no Museu de arte moderna de Frankfurt.

( Ausstellungsfilm "William Forsythe. The Fact of Matter")

https://www.youtube.com/watch?v=OAyNzdaKjIk

Vídeo Improvisational Technologies

(Forsythe-Lines-Point point line-1- Imagining Lines)

https://www.youtube.com/watch?v=6X29OjcBHG8\&list=PLAEBD630ACCB6AD45

William Forsythe - Solo - Improvisational Technologies

https://www.youtube.com/watch?v=hDTu7jF_EwY

William Forsythe - One flat thing reproduced 01/03

https://www.youtube.com/watch?v=cufauMezz_Q

Trecho do trabalho de Forsythe "In the Middle Somewhat Elevated" - Marta Romagna,

Roberto Bolle, Zenaida Yanowsky.

https://www.youtube.com/watch?v=NghGmjtxeak

Entrevista de Forsythe para "dancetechtv"

(William Forsythe on Synchronous Objects, The Hellerau in Dresden, Germany)

https://www.youtube.com/watch?v=xqlq3q5RMrc

Conversa: Freya Vass-Rhee e William Forsythe

(Forsythe Lectures / William Forsythe - Freya Vass-Rhee) - para "deSingel International Arts Campus" 
https://www.youtube.com/watch?v=xqlq3q5RMrc

Conversa: Roslyn Sulcas e William Forsythe

(Forsythe Lectures / Roslyn Sulcas) - para "deSingel International Arts Campus"

https://www.youtube.com/watch?v=Mbe4VavLuLI

Conversa: William Forsythe e Mario Kramer no Museu de Arte Moderna de Frankfurt am Main.

(MMK Talks William Forsythe im Gespräch mit Mario Kramer) - 2015

https://www.youtube.com/watch?v=-arWNGSekkE

Entrevista com Marcel Duchamp -

https://www.youtube.com/watch?v=Bwk7wFdC76Y

Vídeo sobre o arquiteto austríaco Kiesler

https://www.youtube.com/watch?v=LEocPV4T0yQ

Fala de Gabriele Brandstetter.

"BLACK MOUNTAIN - MODELS OF CREATIVITY", Maio 2-3, 2014 (Freie Universität Berlin) - Universidade livre de Berlin.

https://www.youtube.com/watch?v=ZWN_mQkqP5E

Palestra de Steven Spier "Forsythe Lectures" - para "deSingel International Arts Campus" https://www.youtube.com/watch?v=NI8hRRTTHag

http://vimeo.com/51679094

http://www.youtube.com/watch?v=hJ0QUgTCJa0

http://www.youtube.com/watch?v=CKQSiOw1UI4

http://www.inhotim.org.br/

http://processoshibridos.blogspot.de/2010/04/casa-corpo-lygia-clark.html

Itaú cultural. Programa Hélio Oiticica. Projeto Hélio Oiticica.

http://54.232.114.233/extranet/enciclopedia/ho/home/dsp_home.cfm 